\title{
Tertiary Marine Pelecypods of California and Baja California: Plicatulidae to Ostreidae
}

U.S. GEOLOGICAL SURVEY PROFESSIONAL PAPER 1228-G 


\section{Tertiary Marine Pelecypods of California and Baja California: Plicatulidae to Ostreidae}

By ELLEN JAMES MOORE

PALEONTOLOGY OF CALIFORNIA AND BAJA CALIFORNIA

U.S.GEOLOGICAL SURVEY PROFESSIONAL PAPER 1228-C

A total of 68 species representing 23 genera

in the families Plicatulidae, Spondylidae,

Anomiidae, Limidae, Gryphaeidae, and Ostreidae

are illustrated, taxonomy revised and updated,

geographic and geologic ranges given,

occurrence by geologic formation cited,

and habitat included when it can

be confidently inferred

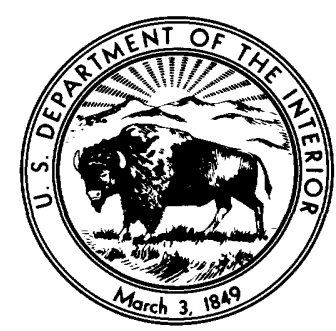

UNITED STATES GOVERNMENT PRINTING OFFICE, WASHINGTON : 1987 


\section{DEPARTMENT OF THE INTERIOR \\ DONALD PAUL HODEL, Secretary}

\section{U.S. GEOLOGICAL SURVEY}

Dallas L. Peck, Director

Library of Congress catalog card no. 86-600557

For sale by the Books and Open-File Reports Section, U.S. Geological Survey, Federal Center, Box 25425, Denver, CO 80225 


\section{CONTENTS}

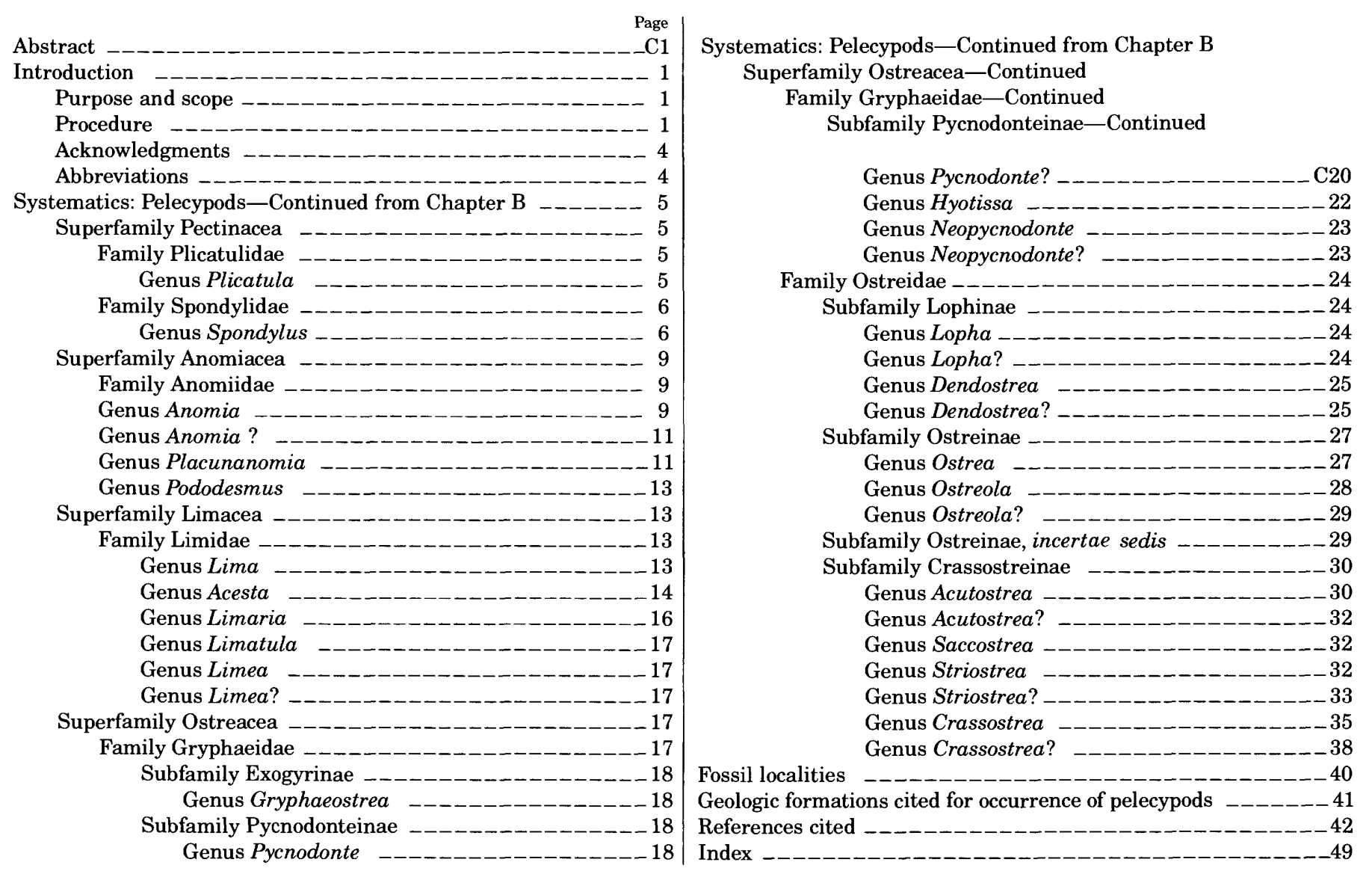

\section{ILLUSTRATIONS}

[Plates follow index]

Plate 1. Plicatula, Spondylus.

2-4. Spondylus.

5. Spondylus, "Spondylus", Anomia.

6. Anomia, Placunanomia.

7-8. Anomia, Placunanomia, Lima, Pododesmus.

9. Spondylus, Limatula, Lima, Pododesmus, Acesta.

10. Lima, Limea?, Acesta, Limaria.

11. Pycnodonte, Dendostrea?.

12. Pycnodonte, Dendostrea?, Striostrea?.

13. Pycnodonte, Dendostrea?, Acutostrea.

14. Pycnodonte?, Dendostrea?, Acutostrea.

15. Pycnodonte?, Dendostrea?

16. Hyotissa, Acutostrea, Pycnodonte?, Striostrea?, Dendostrea?.

17. Lopha, Pycnodonte?.

18. Saccostrea, Pycnodonte?.

19. Gryphaeostrea, Crassostrea?, Pycnodonte?

20. Crassostrea?.

21. Pycnodonte?, Crassostrea?.

22. Crassostrea?, Striostrea?. 
Plate 23. Crassostrea.

24. Crassostrea, Crassostrea?

25. Striostrea?, Crassostrea?.

26-27. Crassostrea, Crassostrea?, Striostrea?

28. Crassostrea.

29. Crassostrea, "Ostrea", Acutostrea, Striostrea?.

30. Ostreola, Acutostrea, Ostrea.

31. Dendostrea?, Ostreola?.

32. Dendostrea?, Ostreola?, Neopycnodonte?, Acutostrea

33. Acutostrea, Acutostrea?, Ostreola?.

34. Ostreola?, Dendostrea?, Acutostrea.

FIGURE 1. Map showing divisions used in California for geographic range of species of pelecypods, Plicatulidae to Ostreidae ---_- C2

2. Map showing divisions used in Baja California peninsula for geographic range of species of pelecypods,

Plicatulidae to Ostreidae

\section{TABLES}

TABLES 1-10. Geologic and geographic distribution:

1. Plicatula

3. Anomia, Anomia? _-

4. Placunanomia, Pododesmus _-

5. Lima, Acesta, Limaria, Limatula, Limea? -

6. Gryphaeostrea, Pycnodonte, Pycnodonte?

7. Hyotissa, Neopycnodonte?, Lopha?, Dendostrea? -

8. Ostrea, Ostreola, Ostreola?, "Ostrea”, Acutostrea, Acutostrea? _-

9. Saccostrea, Striostrea? _-

10. Crassostrea, Crassostrea? 


\title{
TERTIARY MARINE PELECYPODS OF CALIFORNIA AND BAJA CALIFORNIA: PLICATULIDAE TO OSTREIDAE
}

\author{
BY ELLEN JAMES MOORE
}

\begin{abstract}
The description of the mollusks in the Tertiary formations of California and Baja California is continued from Chapter B. The families Plicatulidae, Spondylidae, Anomiidae, Limidae, Gryphaeidae, and Ostreidae, which represent 23 genera and 68 species, are covered in this chapter; other chapters will follow in zoologically systematic order.

All the Tertiary species that were described from or are known to occur in the Californias are included, along with their original descriptions and their distribution by formation. The holotype is illustrated where feasible, and tables show the geologic and geographic occurrence of the species in each genus.

Of the 23 genera studied, the Gryphaeidae and Ostreidae were most in need of taxonomic revision, and only 1 of the 39 species originally assigned to Ostrea is retained in that genus.

The marked response of oysters to their particular habitats causes more variation in shell character within individual species than in any other group of bivalves. The size, shape, and sculpture are all affected by substrate, by crowding, and even by the intensity of available light.

The abundance and gigantic size of Crassostrea and Striostrea during Miocene time in California parallels that of the pectinids during the same time period, just prior to the well documented cooling trend that reached its nadir during the Pleistocene. This population and gigantism explosion may be related to shallow, restricted seaways fed by rivers and streams rich in nutrients, in addition to the known relationship to the temperature of the seas.
\end{abstract}

\section{INTRODUCTION}

\section{PURPOSE AND SCOPE}

The description and illustration of the Tertiary marine mollusks of California and Baja California started in Chapter A is continued in this chapter, which treats the families Plicatulidae to Ostreidae.

A total of 68 species assigned to the included families occur in the geographic study area. For convenience of reference, the figures showing the geographic divisions used for the Californias are reproduced (figs. 1, 2).

\section{PROCEDURE}

All Tertiary marine mollusks originally described from California and the Baja California peninsula, and all species originally described from other geographic localities but known to occur in the Tertiary of the Californias, are included in this study. All positively identified species that have been found on faunal lists are also included. In genera that are extremely rare, I have included species that are only questionably identified.

In this work, species are arranged systematically following the order of families, genera, and subgenera given in the Treatise (Moore, 1969; 1971). The order in which families are arranged and the generic and subgeneric categories have generally not been modified, except in a few cases. Most modifications made reflect either definitive papers published after publication of the Treatise or works published earlier but not cited in it. Within the systematic groups, species are arranged by geologic age, beginning with the oldest species and ending with the youngest.

Some of the names of genera and subgenera adopted in this paper have not been used before for eastern Pacific Tertiary species. Brief synopses of generic and subgeneric characters are given in the appropriate places; more complete synopses will be found in the Treatise (Moore, 1969; 1971), in Keen (1971), in Hertlein and Grant (1972), and in Olsson (1961). For genera and subgenera that are not included in the Treatise, complete descriptions are given in the text.

Distribution tables are included to show graphically the geographic and geologic distribution of species within each family. To facilitate finding a specific taxon, the species are listed alphabetically under genus and subgenus in the tables.

The synonymy for each species includes the original citation and subsequent substantive references. The 


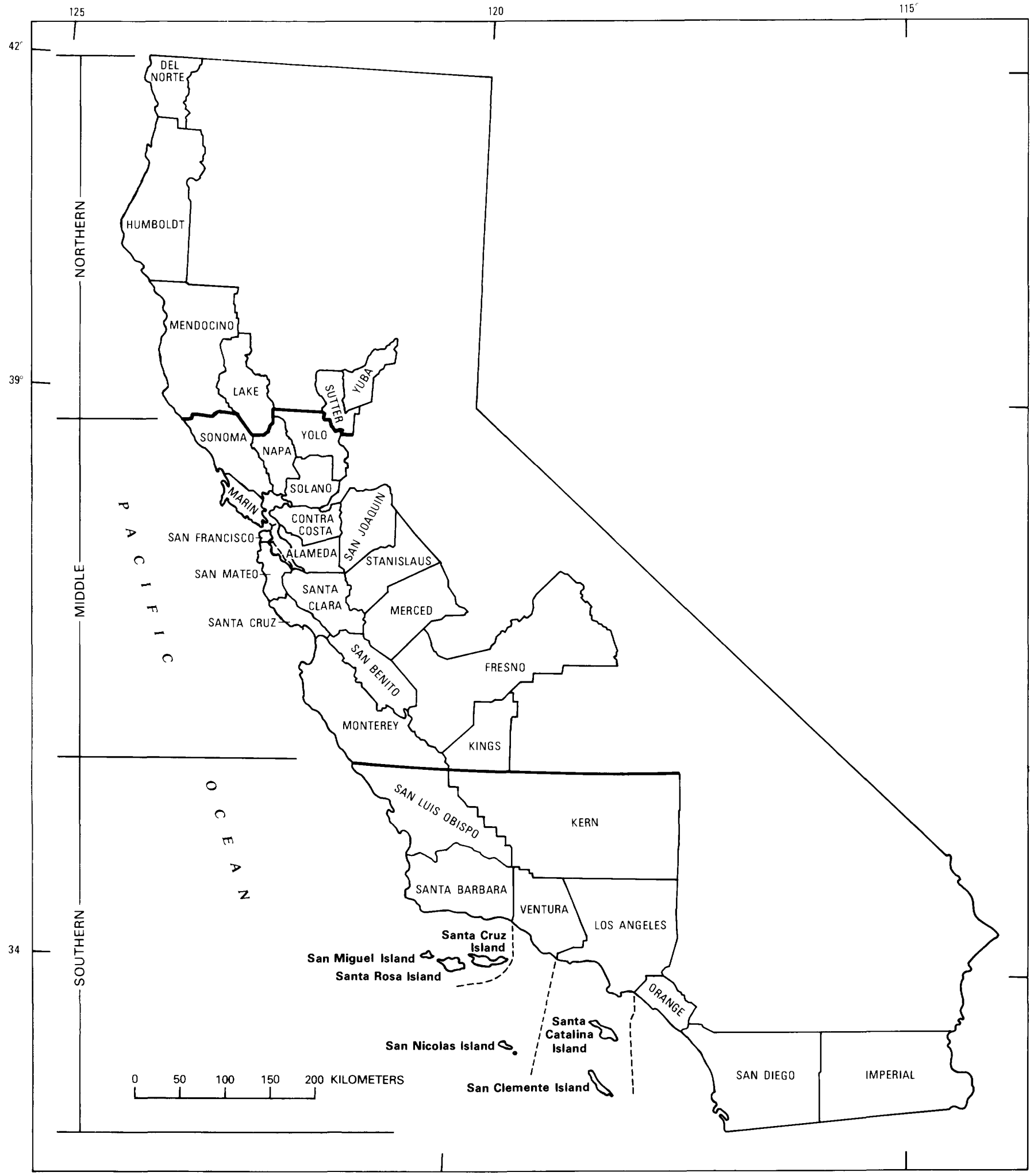

FIGURE 1.-Divisions used for geographic ranges of species of pelecypods, Plicatulidae to Ostreidae, reported from California. Heavy solid lines indicate northern, middle, and southern divisions; dashed lines within southern region divide Channel Islands area. 


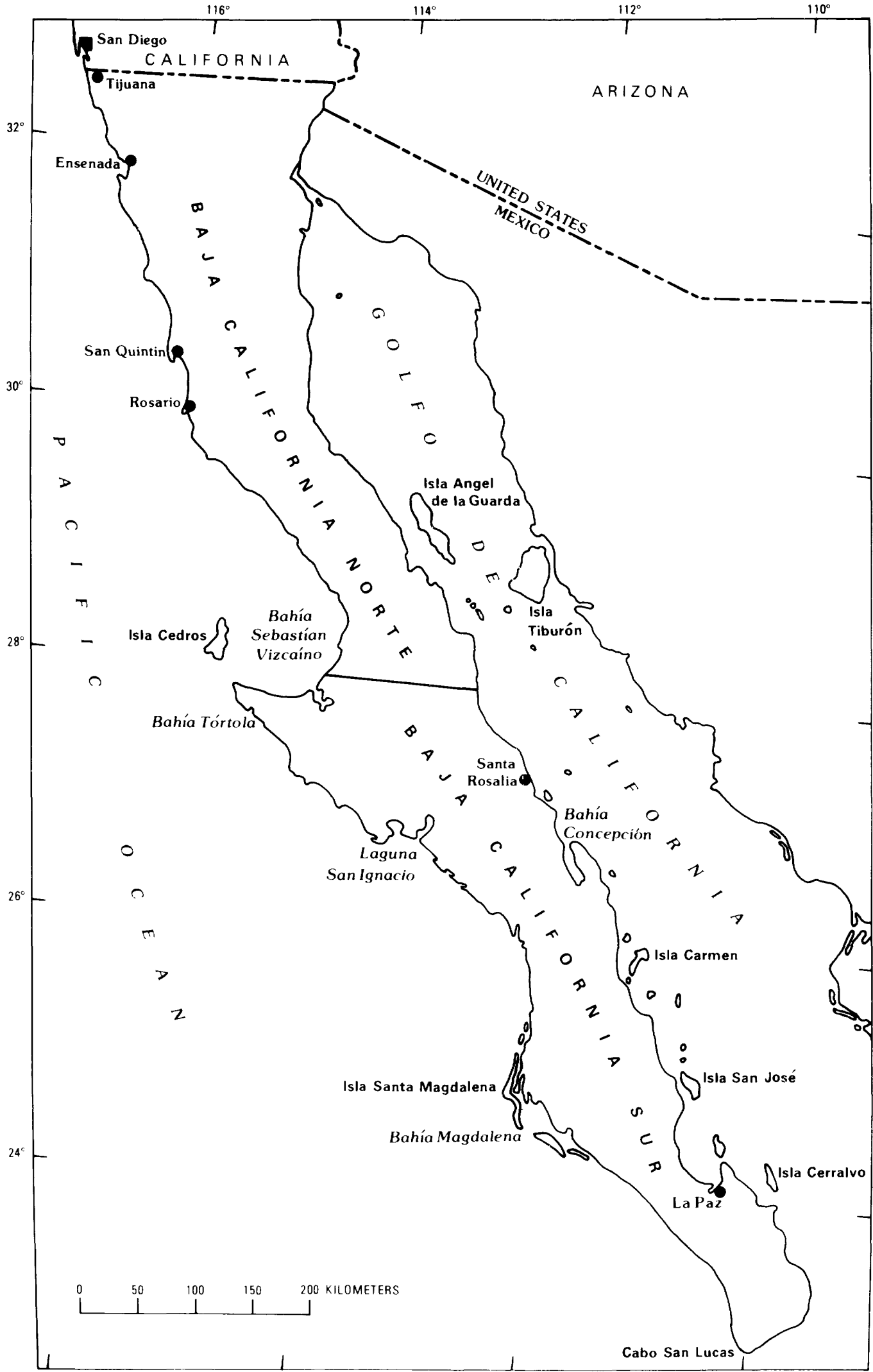

FigURE 2.-Divisions used for geographic ranges of species of pelecypods, Plicatulidae to Ostreidae, reported from Baja California peninsula. 
accuracy of identifications cited in subsequent references in the synonymy has not been verified.

The type is usually that of the author of the original description or of later workers who selected a lectotype or neotype. Where the original locality description is so vague that it is of little use, the type locality is described as corrected or modified by other workers such as Keen and Bentson (1944) and the modifications given within brackets. All other localities are cited as originally described except that the formation given is that currently used.

Previously published supplementary descriptions and comparisons are included and I have supplemented this in the section headed "Comments". For most descriptions, my comments are based only on examination of primary type material.

All available published data for each species have been included in the section on geographic and geologic age range, including that contained in faunal lists when the identification is unqualified. Age ranges have not been refined within epochs. Where a stage name the same as a formation name is used, it is placed in quotes to distinguish it from the rock unit.

The divisions used here to indicate the approximate geographic range of species within California based on county distribution are northern, middle, and southern (fig. 1); the divisions for the Baja California peninsula, Norte and Sur (fig. 2) (tables 1-10).

An attempt has been made to include all citations to a species that are unqualified and every geologic formation in which it is reported to occur in the Californias. The assumption has been made that all identifications of species are correct unless there is strong evidence to the contrary. The stratigraphic nomenclature used herein is that of the author(s) cited and does not necessarily agree with that of the U.S. Geological Survey. The age given for the stratigraphic units follows the classification of geologic time currently used by the U.S. Geological Survey. (See "Geologic Formations Cited for Occurrence of Pelecypods" at end of paper.) Each formation listed is followed by the name of the author and date of publication of the work from which it was obtained. More than one reference to a formation is given where it might be useful to the reader. The list of formations given for species occurrence should not be considered complete or necessarily accurate. Many western American Tertiary faunas have not been monographed, and their species content is not fully known. It is hoped that the list of formational occurrence reported will serve as a framework upon which the true distribution of each species can be built.

The type specimens were all photographed by Kenji Sakamoto, U.S. Geological Survey. Owing to the fact that the specimens photographed were borrowed from other institutions, Sakamoto did not use his usual technique of opaquing specimens for photography (Sakamoto, 1973). The holotype of each Tertiary species is figured if the type is extant. Holocene type specimens have not been figured; specimens considered to be of the same species by authors such as Durham (1950) and Hertlein and Grant (1972) are used for these illustrations, and this information is included in the plate explanation.

\section{ACKNOWLEDGMENTS}

Kiyotaka Chinzei, University of Tokyo, Japan, A. Myra Keen, Santa Rosa, Calif., and John G. Vedder, U.S. Geological Survey, reviewed the manuscript, and their pertinent suggestions were most helpful. Harold W. Harry, Bellaire, Texas, read the section on oysters, suggested generic revisions based on his studies of soft part anatomy and shell characters, and furnished ecologic data for the group.

The following individuals made available or loaned type material or made arrangements for photography, and I am indebted to them: Barbara A. Bedette, U.S. Geological Survey; Frederick J. Collier, National Museum of National History; Vickie Kohler, Museum of Comparative Zoology; Carole J. Hickman, University of California at Berkeley; Barry Roth, California Academy of Sciences; Lou Ella Saul, University of California, Los Angeles, Charles L. Powell, II, U.S. Geological Survey, Menlo Park, Calif., Carol C. Jones, Philadelphia Academy of Sciences; Frederick R. Schram, San Diego Natural History Museum; Druid Wilson, Smithsonian Institution; and Edward C. Wilson, Los Angeles County Natural History Museum.

Mildred P. James made up cards for each species and its occurrences as noted on faunal lists. This was a timeconsuming task, and I thank her for her patience and support.

\section{ABBREVIATIONS}

ANSP: The Academy of Natural Sciences of Philadelphia, Philadelphia, Pa.

BM (NH): British Museum of Natural History, London, England.

CAS: California Academy of Sciences, San Francisco, Calif.

LAM: Los Angeles County Museum of Natural History, California.

MCZ: Harvard Museum of Comparative Zoology, Cambridge, Mass.

SDNM: San Diego Natural History Museum, California.

CAS/SU: Stanford University, Stanford, Calif. [The 
Stanford University collections are now housed at the California Academy of Sciences.]

SU: Stanford University, Stanford, Calif.

UC: University of California, Berkeley.

UCMP: University of California, Museum of Paleontology, Berkeley.

UCR: University of California at Riverside.

USGS: U.S. Geological Survey, Washington, D.C., Cenozoic locality register.

USGS M: U.S. Geological Survey, Menlo Park, Calif., Cenozoic locality register.

USNM: National Museum of Natural History, Washington, D.C.

UW: University of Washington, Seattle, Wash.

\section{SYSTEMATICS: PELECYPODS-CONTINUED FROM CHAPTER B}

\section{Superfamily PECTINACEA Family PLICATULIDAE Genus PLICATULA Lamarck, 1801}

Subequivalve or with right valve usually more convex, cardinal area small, resilium pit acutely triangular, adductor scar in relatively posterior position.

\section{Subgenus PLICATULA}

Auricles absent or ill-defined, most species with radial sculpture and imbricating concentric lamellae; short spines common.

Geographic range.-Living: restricted to tropics; fossil: cosmopolitan.

Geologic range.-Triassic to Holocene (table 1).

Habitat.-At depths from intertidal zone to $140 \mathrm{~m}$ in the eastern Pacific (Bernard, 1983, p. 24).

\section{Plicatula ostreiformis Stanton \\ Plate 1, figures 1-3}

Plicatula ostreiformis Stanton, 1896, p. 1038, pl. 63, figs. 5-6.
Plicatula ostreaformis Stanton. Dickerson, 1914, p. 151, pl. 9, fig. 12 [error for ostreiformis].

Original description.- - "Shell large, irregularly ovate in outline, but varying considerably in this respect; valves subequal, the right one being usually slightly convex and the left flattened or a little concave in the middle; test unusually thick; surface with obscure radiating plications and irregular pits."

Syntypes.-USNM 157838.

Type locality.-One mile $[1.6 \mathrm{~km}]$ southeast of Lower Lake $[\mathrm{NE1} / 4, \mathrm{~T}$. 12 N., R. 7 W.], Lake County, Calif.. Martinez Formation, Paleocene. Supplementary description.- "An average specimen measures 52 $\mathrm{mm}$. in length, $39 \mathrm{~mm}$. in breadth, and $19 \mathrm{~mm}$. in greatest convexity of the two valves united.

"Internal casts show impressions of the characteristic hinge of Plicatula." (Stanton, 1896, p. 1038)

Geographic range.--Northern California.

Geologic range.-Paleocene.

Occurrence in California.-Paleocene: Martinez Formation (Dickerson, 1914).

\section{Plicatula penicillata Carpenter \\ Plate 1, figures 4, 6, 8, 9}

Plicatula penicillata Carpenter, 1857, p. 155-156. Durham, 1950, p. 69, pl. 13, figs. 2, 5. Olsson, 1961, p. 154-155. Keen, 1971, p. 94, fig. 208.

Original description.- - "P. t. albâ, brunneo saepe tenue penicillatâ, elongata, haud valde costatâ, margine plerumque plicatâ; dentibus cardinalibus elongatis, rugosis, externis magnis valde extantibus; intermis angustis, ligamentum minimum tabulatum amplectentibus; cicatrice musculari subcirculari seu subovali."

Holotype.-BM(NH) Tablet 701; missing?

Type locality.-Mazatlan, Mexico.

Supplementary description.- "A very young valve .15 across is not plicated: a larger flat specimen on Crepidula is ribbed, but scarcely plaited at the margin: a still larger one is but very indistinctly ribbed. A swollen short specimen, grown on a spine of Murex nigritus, is rather strongly plicated; while the largest $* * *$, grown between two folds of Chama, scarcely displays crenations, except near the hinge. The finest grown specimen displays the following characters: margin scarcely plicate, internally finely crenated on each side of the hinge: a deep hollow in each valve running up inside the umbos: central teeth (on the attached valve) joined together for more than half their height,

TABLE 1.-Geologic and geographic distribution of the genus Plicatula in the eastern Pacific region $[\mathrm{H}=$ Holocene; $\mathrm{Pl}=$ Pliocene; $\mathrm{Pa}=$ Paleocene $]$

\begin{tabular}{|c|c|c|c|c|c|c|}
\hline \multirow[t]{2}{*}{ Species } & \multicolumn{3}{|c|}{ California } & \multicolumn{2}{|c|}{ Baja California } & \multirow{2}{*}{$\begin{array}{l}\text { Central } \\
\text { or South } \\
\text { America }\end{array}$} \\
\hline & Northern & Middle & Southern & Norte & Sur & \\
\hline \multirow{3}{*}{$\begin{array}{l}\text { Genus Plicatula } \\
\text { ostreiformis Stanton............. } \\
\text { penicillata Carpenter........... } \\
\text { spondylopsis Rochebrune..... }\end{array}$} & $\mathrm{Pa}_{\mathrm{a}}$ & $\ldots$. & $\ldots .$. & $\ldots .$. & $\ldots .$. & $\ldots .$. \\
\hline & $\ldots$. & $\ldots .$. & $\ldots .$. & $\ldots .$. & $\mathrm{Pl}$ & $\mathbf{H}$ \\
\hline & $\ldots .$. & $\ldots \ldots$ & $\cdots \cdots$ & $\ldots .$. & $\mathrm{Pl}$ to $\mathrm{H}$ & $\mathbf{H}$ \\
\hline
\end{tabular}


holding the ligament, which is extremely small, tubular, only exposed at the extremities, and running up to the umbos, though not exposed (or scarcely covered) as in Spondylus, but nearer the interior of the shell. In the free valve, the ligamental tube rises up separating the pits of the inner teeth. In this specimen the muscular scar is almost round; in another, rather oval. The valves are held together by the interlocking of the large rugose teeth.' (Carpenter, 1857, p. 156)

"Shell variable in size and shape from nearly circular, flattened forms to irregularly humped, elongate-ovate types, the lower valve is usually broadly attached over most of its surface. Upper valve may show a few, irregular, ill-defined riblets around the margin or the whole surface may be flat and plain or with an occasional short, hollow, spinelike elevation rising above it." (Olsson, 1961, p. 154).

Geographic range.-Living: Galapagos Islands and Ecuador; fossil: Baja California Sur.

Occurrence in Baja California Sur-Pliocene: Marquer Formation (Durham, 1950).

Habitat.-Intertidal zone (Bernard, 1983, p. 24) in rock crevices or inside dead shells (Keen, 1971).

\section{Plicatula spondylopsis Rochebrune}

\section{Plate 1, figures 7, 10}

Plicatula spondylopsis Rochebrune, 1895, p. 242. Hertlein, 1934a, p. 62, pl. 21, fig. 9. Durham, 1950, p. 69, pl. 15, fig. 2. Olsson, 1961, p. 155. Keen, 1971, p. 94, 96, fig. 209.

Original description.- "Testa transverse ovato rotundata, crassissima, affixa; valvis radiatim costato sulcatis, costis squamis imbricatis ornatis; marginibus intense dentatis; extus sordide lilacina, intus alba."

Holotype.-In Paris Museum.

Type locality.-Laguna des Isles de San Jose, Golfo de California. Supplementary description.-- "Shell roughly trigonal in shape, ornamented by coarse radial plaited sculpture, which, however, may be partially or almost wholly absent on some specimens; two hinge teeth in each valve ${ }^{* * *}$ Muscles scar nearer the posterior margin." (Olsson, 1961, p. 155)

Comparison.-"Differs from $P$. penicillata by its smaller area of attachment, usually thicker, vaulted shell, and strong ribs. Some specimens of Plicatula in the U.S. National Museum, probably belonging to this species are sharply plicated and resemble $P$. gibbosa Lamarck of the Western Atlantic." (Olsson, 1961, p. 155).

Geographic range.--Living: Golfo de California to Ecuador and Galapagos Islands; fossil: Baja California Sur.
Occurrence in Baja California Sur--Pliocene: Marquer Formation (Durham, 1950); Pleistocene: Isla Maria Magdalena (Durham, 1950). Habitat.-Intertidal zone to $5 \mathrm{~m}$ (Bernard, 1983, p. 24).

\section{Family SPONDYLIDAE}

"Cemented Pectinacea lacking simple, prismatic calcite; crossedlamellar aragonite prominent, extending well outside pallial line nearly to distal margins and covering hinge plate, which bears prominent dysodont teeth. Byssal notch generally present in early growth stages and lacking a ctenolium. Mantle curtains without guard tentacles.

"The early ontogeny of the spondylid ligament is precisely like that of pectinids, with the central, lamellar portion of the resilium being continuous with the anterior and posterior outer ligaments, which continue throughout ontogeny along the straight hinge. The lateral fibrous pads originate as in the Pectinidae. The grooves, which arise late in ontogeny and in many cases become multiple, appear to be nothing more than crenulations of the resilium possibly resulting from confinement to a narrow space." (Waller, 1978, p. 354).

Geologic range.-Jurassic through Holocene.

\section{Genus SPONDYLUS Linné, 1758}

Well inflated, mostly with strong radial sculpture, many forms spiny or foliaceous; cardinal area of right valve large, triangular; crural teeth short, heavy, smooth, or with weakly crenulated edges. Geologic range.-Jurassic through Holocene (table 2).

Geographic range.-Living: restricted to the tropics; fossil: cosmopolitan.

Habitat.-Spondylus attaches to a rock surface by cementation of the right valve, with the exception of the species Spondylus regius Linné which is not ordinarily attached. The right valve shows great variation depending upon the shape of the object chosen for attachment and the size of the area of the shell attached (Dodge, 1952, p. 125). Spondylus is commonly attached to littoral boulders which are usually covered by fine growths of algae extending equally over the rock and over the shell (Purchon, 1977, p. 178-179).

\section{Spondylus carlosensis Anderson}

\section{Plate 1, figure 5}

Spondyluscarlosensis Anderson, 1905, p. 194, pl. 13, fig. 1. Arnold, 1909 [1910], p. 13, pl. 2, figs. 6, 7. Vokes, 1939, p. 57, pl. 3, figs. 10, 13.

TABLE 2.-Geologic and geographic distribution of the genus Spondylus in the eastern Pacific region

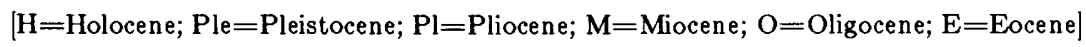

\begin{tabular}{|c|c|c|c|c|c|c|}
\hline \multirow[t]{2}{*}{ Species } & \multicolumn{3}{|c|}{ California } & \multicolumn{2}{|c|}{ Baja California } & \multirow{2}{*}{$\begin{array}{l}\text { Central } \\
\text { or South } \\
\text { America }\end{array}$} \\
\hline & Northern & Middle & Southern & Norte & Sur & \\
\hline $\begin{array}{l}\text { Genus } \text { Spondylus } \\
\text { bostrychites Guppy........... } \\
\text { calcifer Carpenter............ } \\
\text { carlosensis Anderson...... } \\
\text { cliffensis M.A. Hanna..... } \\
\text { perrini Wiedey................. } \\
\text { princeps Broderip............. }\end{array}$ & $\begin{array}{l}\cdots \cdots \\
\cdots \cdots \\
\cdots \cdots \\
\cdots \cdots \\
\cdots \cdots \\
\cdots \cdots\end{array}$ & $\begin{array}{c}\cdots \cdots \\
\ldots \\
\ldots \\
\cdots \\
O \text { and } M\end{array}$ & $\begin{array}{c}\mathrm{M} \text { or } \mathrm{Pl} \\
\mathrm{M} \text { or } \mathrm{Pl} \text { and } \mathrm{Ple} \\
\mathrm{E} \\
\mathrm{E} \\
\mathrm{O} \text { and } \mathrm{M} \\
\ldots . . .\end{array}$ & $\begin{array}{c}\cdots . . \\
\text { Pl to } \mathrm{H} \\
\ldots . . \\
\ldots . . \\
\ldots . . \\
\text { Ple }\end{array}$ & $\begin{array}{c}\ldots . . \\
\text { Ple and } \mathrm{H} \\
\ldots . . \\
\ldots . . \\
\ldots . . \\
\text { Pl to } \mathrm{H}\end{array}$ & $\begin{array}{c}\cdots \cdots \\
\mathrm{H} \\
\cdots \\
\cdots \cdots \\
\cdots . . \\
\mathrm{H}\end{array}$ \\
\hline
\end{tabular}


Original description.- "Shell of medium size, sub-circular or 0bliquely ovate, radially ribbed, convex; costae granulated or obscurely spinose; ears and hinge rather broad. The costae radiate in graceful sinuous lines from the beak to the margins, and occur in pairs or triplets, every second or third rib being more elevated than the others." Holotype.-CAS 56.

Type locality.-West and north of Coalinga [NW1/4, sec. 35; T. $20 \mathrm{~S}$., R. 14 E.], Fresno County, Calif. Domengine Formation, Eocene.

Supplementary description.- "The left valve figured is irregular in outline. There is a well-marked regular umbonal area of development during the period preceding attachment. The sculpture consists of irregular, sharp, round-topped ribs of varying strength, usually large ribs alternating with smaller ones, with approximately nine more prominent noded ribs subequally spaced over the surface of the valve. The ears have been broken.

"The hinge shows long auricular crurae, buttressed ventrally by two ridges. The ligamental groove is long and narrow, extending to the apex; the crural sockets are subtriangular, set beneath the umbonal ends of the crurae." (Vokes, 1939, p. 57)

Comparison.- "Spondylus cliffensis $* * *$ is a smaller species and appears to be characterized by the possession of a longer hinge-line." (Vokes, 1939, p. 57).

Geographic range.-Middle and southern California.

Geologic range.-Eocene.

Occurrence in California.-Eocene: Avenal Sandstone (Stewart, 1946), Domengine and Tejon Formations (Vokes, 1939), and Cozy Dell Shale (Weaver and Kleinpell, 1963).

\section{Spondylus cliffensis M. A. Hanna}

\section{Plate 2, figure 3}

Spondylus cliffensis M. A. Hanna, 1927, p. 278, pl. 32, figs. $2,7$.

Original description.- - "Shell small, inequilateral, subcircular, only slightly inflated; beaks not prominent or central; hinge line straight; surface distorted; ornamented by many small prominent sharp roundtopped ribs of various sizes; usually large ribs alternate with smaller ones, every third to fifth large rib more prominent, some of the very large ribs appear to be noded; surface crossed by a few indistinct growth lines. Dimensions: Altitude $25.5 \mathrm{~mm}$, length $29 \mathrm{~mm}$."

Holotype.-UCMP 31025.

Type locality.-UC 5062. San Diego County, Calif. Rose Canyon Shale (Hanna, 1926), Eocene.

Comparison.-Spondylus cliffensis is smaller and seems to have a longer hinge line than S. carlosensis (Vokes, 1939, p. 57).

Geographic range.-Southern California.

Geologic range.-Eocene.

Occurrence in California.-Eocene: Rose Canyon Shale (Hanna, 1927).

\section{Spondylus perrini Wiedey}

Plate 2, figures 1, 4-7; plate 9, figure 1

Pecten (Hinnites) giganteus Gray. Eldridge and Arnold, 1907, pl. 32, fig. 1. Not Pecten (Hinnites) giganteus Gray, 1825.

Spondylus perrini Wiedey, 1928, p. 138, pl.17, figs. 6, 7. Loel and Corey, 1932, p. 203, pl. 32, figs. 1a, 1b, 1c, 2. Avila and Weaver, 1969, p. 59, pl. 34, figs. 11a, 11b.

Spondylus inezana Wiedey, 1928, p. 139, pl. 16, figs. $2,3$.

Original description.- "Shell large, variable in shape, narrowly ovoid, very inequivalve, slightly inequilateral, and very strongly inflated. Anterior dorsal margin not long, quite straight, sharply truncated at the extremity, curving into the broadly rounded basal margin, which varies in the degree of curvature owing to the irregularity of outline of the shell. Posterior dorsal margin short, curving slightly from its gently rounded extremity to the hinge line. Umbo of the left valve of much greater size than the umbo of the right valve. It is long, narrow, highly arched, and projected very markedly over the corresponding feature of the right valve. Umbo of the right valve, if elevated, is broadly inflated and quite blunt. The beaks are strongly incurved, sharp, and prominent. The sculpturing consists of about twelve or more prominent ribs, which are rendered rugose by having small spines, which evidently projected sharply forward, now broken away. Two or more smaller ribs sculpture the very wide interspaces. Incremental sculpture prominent. The hinge line is very short and the ears are very subdued and not prominent. The areas adjacent to the ears under the umbones in the combined valves are deeply depressed. Length, $85 \mathrm{~mm}$.; breadth, $59 \mathrm{~mm}$.; thickness of the combined valves, $60 \mathrm{~mm}$.; the left valve projects as much as $20 \mathrm{~mm}$. over the right valve in some individuals." (perrini)

"Shell very large, of variable shape, generally subcircular, inequivalve to a large degree, inequilateral, and slightly to moderately inflated in most individuals. Anterior dorsal margin often long and nearly straight to broadly rounded, more sharply curved at its extremity. Basal margin broadly rounded to the posterior dorsal extremity, which is a little more sharply rounded. The posterior dorsal margin is quite broadly curved but may be straight and long. Umbones of subequal size, with the left valve possessing the more prominent umbo, which is generally moderately elevated and projected slightly over the umbo of the right valve. Beaks in most forms obscured, but apparently distant, situated in the anterior portion of the shell and not prominent. The left valve is the more strongly convex with occasional individuals possessing a nearly flat right valve. Valves sculptured by about fifteen prominent radiating ridges, which are narrow and appear to have supported numerous small spines, projecting obliquely forward. The ribs are more prominent on the central parts of the valves and less distinct toward the dorsal margins. Between the heavier ribs is another system of ribbing in the wide interspaces, consisting of a rather fine median rib flanked by a varying number of finer threadlike riblets, generally four or more. Concentric wavy lines of growth become very prominent on the older parts of the shell and assume the character of wavy folds in some of the old individuals. Hinge line not long; ears vary in size, projecting moderately on either side of the beaks. Length, $72 \mathrm{~mm}$.; breadth, $60 \mathrm{~mm}$.; thickness of the combined valves, $45 \mathrm{~mm}$." (inezana)

Holotype.-SDNM 28 [SDNM 438 in original text is in error]; of $S$. inezana Wiedey, SDNM 29.

Type locality.-SDNM and SU 437. Head of Wiley Canyon [S1/2, sec. 12, T. 3 N., R. 19 W., S.B. Piru quad.], Ventura County Calif. Vaqueros Formation, Oligocene and Miocene; of $S$. inezana, the same locality.

Supplementary description.- -Wiedey describes two species, $S$. perrini and $S$. inezana, from the same locality and same bed. He states that both are very variable and that $S$. inezana differs in being less convex and more circular in outline.

"Study of a large number of specimens from the type and other localities in the region has shown that there is but one species present-Spondylus perrini Wiedey by priority. The characters of convexity, valve equality, and height of umbo in the left valve are all differential in development, variability being of course due to the attached mode of habitat. It is the inequivalve variant form described by Wiedey as $S$. perrini, with the lower valve largest, which is usually comparatively less convex, not the reverse case as Wiedey states.

'The variant described as 'S. inezana,' in which individual valves are more nearly equivalve owing to position of attachment, is usually much more convex (the reverse of Wiedey's observations)." (Loel and Corey, 1932, p. 203)

Geographic range.-Middle and southern California.

Geologic range.-Oligocene and Miocene. 
Occurrence in California.-Oligocene and Miocene: Rincon Shale (Avila and Weaver, 1969) and Vaqueros Formation (Loel and Corey, 1932); Miocene: Monterey Shale (Avila and Weaver, 1969).

\section{Spondylus bostrychites Guppy}

Plate 2, figure 2; plate 3, figure 2; plate 9, figures 3, 9

Spondylus bostrychites Guppy, 1867, p. 176. Woodring, 1925, p. 76-77, pl. 9, figs. 5-7. G D. Hanna, 1926a, p. 477, pl. 24, figs. 3, 4. Palmer, 1938, p. 152-155, pl. 1, figs. 1, 2; pl. 2, figs. 1, 3, 5; pl. 3, figs. 1-5.

Original description.- "Testa subregularis, totondata, ventricosa, margine latiusulco, valide denticulateo; extus radiatim costata, costa 5 and 6 spiniferis; area cardinali alterius valvae angustissima, alterius latiori."

Lectotype.-BM(NH) R 12833 (Palmer, 1938).

Type locality.-Dominican Republic, Gurabo Formation, Miocene. Supplementary description.- “*** specimens *** show that $S$. bostrychites may have concentric ribs over the umbonal portion of the right valve. One of the right valve paratypes has conspicuous, concentric ribs on the attached area. The factor of concentric lamellae is taken up in detail because authors have used the presence or absence of concentric ribs in specific determination. When concentric foliations do not occur below the point of adherence they may be present or absent and are not of specific value in such species as $S$. bostrychites Guppy.

"Large spines project from the radiating ribs of $S$. bostrychites. The spines are common on the primary ribs but by no means limited to the primary ribs as has usually been described by writers. Numerous spines may be seen on secondary ribs on paratypes 3 and $4 * * *$. The lectotype has incipient spines on secondary ribs. The whole surface of the shell is sculptured with scaly, concentric lines giving the radiating ribs a lamelliform appearance. Specimens Nos. 3 and 4 have the posterior end produced in both valves. Specimen No. 5 shows a slight posterior production. Specimen No. 2 has conspicuous, concentric ribs on the umbonal region." (Palmer, 1938, p. 152, 153).

Geographic range.-Southern California; Dominican Republic, Jamaica? (Palmer, 1938).

Geologic range.-Miocene or Pliocene.

Occurrence in California.-Miocene or Pliocene: Imperial Formation (G D. Hanna, 1926a).

\section{Spondylus calcifer Carpenter \\ Plate 4, figures 1, 2, 4, 5}

Spondylus calcifer Carpenter, 1857, p. 152-155. G D. Hanna, 1926a, p. 477. Jordan, 1936, p. 112. Olsson, 1961, p. 153. Emerson and Hertlein, 1964, p. 350. Keen, 1971, p. 96, fig. 210.

Original description.- -S. t. maximâ, ponderosâ, solidâ, plerumque orbiculari; rubropurpureo; valvâ superiore costis minimis aculaetis creberrimis tectâ, huc et illuc costis irregularibus squamosis; squamis curtis, ad basim arcuatis, supra foliatis; valvâ inferiore plerumque foliatâ; areâ ligamenti magnâ, ligamenta haud tecto; intus subnacreâ, limbo lato toto purpureo, seu nonnumquam flavesco-rubente; margine extremo creberrime et minute crenulato; dentibus validis; fossâ ligamenti canalibus 2-6 parallelis, decussatis; musc. imp. suborbiculari, magnâ."

Syntypes.-BM(NH) Tablet 692 to 699.

Type locality.-Bay of Panama.

Supplementary description.- "Shell of medium or large size, often becomes coarse and heavy, rounded or much deformed due to fixation and growth, the valves then unsymmetrical in shape and in details of sculpture. Attachment is usually by a major part of the surface of the lower valve, often along one side of the umbonal slope, the free surface covered with foliated concentrics which aid in fixation. Surface of the upper valve sculptured with numerous rows of radial spines, short or of medium length; on the middle of the disk, these spines are largest and of uniform size (not divided into sets of primary, secondary, or tertiary strength) but diminish in strength towards the sides and may be wholly absent from the anterior slope. Radial spaces between the ribs is usually wide and plainly marked with fine and coarse threads, the middle one sometimes bearing small spines." (Olsson, 1961, p. 153)

Comparison.-Young shells of S. calcifer may be hard to distinguish from those of Spondylus princeps Broderip; generally the spines are more numerous and evenly distributed on S. calcifer (Keen, 1971, p. 96).

Geographic range.-Living: Golfo de California to Ecuador; fossil: southern California to Baja California Sur.

Geologic range.-Miocene or Pliocene through Holocene.

Occurrence in the Californias.-Miocene or Pliocene: Imperial Formation (G D. Hanna, 1926a); Pliocene: Almejas Formation (Jordan and Hertlein, 1926b); Pliocene and Pleistocene: Fernando Formation (J. D. Mount, written commun., 1971); Pleistocene: unnamed strata at Bahía Magdalena (Jordan and Hertlein, 1926b).

Habitat.-At a depth of 2-55 $\mathrm{m}$ in the eastern Pacific (Bernard, 1983, p. 27).

\section{Spondylus princeps Broderip}

Plate 3, figures 1, 3-10; plate 4, figures 3, 6; plate 5, figure 6

Spondylus princeps Broderip, 1833, p. 4. Hertlein and Strong, 1946, p. 62- 63. Hertlein, 1957, p. 66-67.

Spondylus princeps princeps Broderip. Olsson, 1961, p. 152, pl. 22, figs. 4,$8 ;$ pl. 86, figs. 1, 1a. Keen, 1971, p. 96, fig. 211.

Spondylus crassisquama Lamarck of authors; not Lamarck, 1819.

Spondylus victoriae Sowerby. Durham, 1950, p. 68, pl. 15, fig. 3; not Spondylus victoriae Sowerby, 1859.

Original description.- "Spond. testâ rotundatâ, 6-costatâ, rubrâ spinosâ, spinis lingulatis, latis; costis interstitialibus 5 spinosis, spinis brevioribus; intùs albâ, limbo lato profundè plicato, rubro: long. $5 \frac{1}{1}$, alt. 5 , lat. 3 poll. (spinis haud inclusis)."

Holotype.-BM(NH).

Type locality. - Isla la Plata, Ecuador. Found attached to coral rocks at the depth of 17 fathoms.

Supplementary description.--Shell usually regular in shape, the valves seldom showing much distortion, the attachment area usually small. Valves not strongly convex. Sculpture of crowded, or close-set, short or medium-length, spikelike spines. Primary and secondary spines set in six rows, the tertiary in pairs of two in the space between the primary and central secondary (four in the larger interspaces between the primaries). Inner marginal band wide and deeply colored. *** The subspecies is readily distinguished by its crowded, spikelike spines, showing no open spaces between them." (Olsson, 1961, p. 152)

Geographic range.-Living: Laguna de Scammon to Negritos, Peru, and Golfo de California; fossil: Baja California Sur.

Geologic range.-Pliocene through Holocene.

Occurrence in Baja California Sur.-Pliocene: Almejas (Minch and others, 1976) and San Marcos (Durham, 1950) Formations; Pleistocene: unnamed strata on Isla Coronados (Emerson and Hertlein, 1964).

Habitat.-At depth of 2-40 m (Bernard, 1983, p. 27).

\section{"Spondylus estrellanus Conrad"}

\section{Plate 5, figure 2}

Spondylus estrallensis Conrad, 1857a, p. 315 [error for estrellanus]. Spondylus estrellanus Conrad, 1857c, p. 191, pl. 1, fig. 3. 
Original description._- "Obtusely ovate; both valves ventricose; ribs 17 , not very prominent, rounded, rugose; valves with radiation striae."

Type.-A specimen (USNM 13312) is in the U.S. National Museum type collection labelled, presumably by Conrad, from Estrella Valley, Calif., and catalogued in 1884 (pl. 5, fig. 2). It does not compare well with the specimen figured by Conrad (1857c, pl.1, fig. 3) that is missing and presumed lost. This specimen (USNM 13312) is not a Spondylus; it is Lyropecten estrellanus (Conrad, 1857a). Conrad did not describe the hinge area of Lyropecten estrellanus in his original description, and I assume that the hinge was not exposed. However, the specimen he described as Spondylus estrellanus did have the hinge exposed, and he described the hinge as having lateral tubercles or teeth that are prominent, conical, and very robust (1857c, p. 191). Perhaps the strong crura led him to believe that the species was Spondylus rather than Lyropecten. The original illustration of Spondylus estrellanus (Conrad, $1857 \mathrm{c}$, pl. 1, fig. 3), which resembles Lyropecten estrellanus somewhat, shows none of the characters of Spondylus. All available evidence points to the conclusion that Conrad did not have a Spon$d y l u s$ in his collections from Estrella Valley and mistakenly identified some specimens of Lyropecten estrellanus as Spondylus. The description of "Pallium" estrellanus is on page 313 and that of "Spondylus" estrellanus on page 315 (Conrad, 1857a), thus giving page priority to Lyropecten estrellanus.

Type locality.-Estrella Valley [T. 26 S., R. 13 E., San Luis Obispo County], Calif. Santa Margarita Formation, Miocene.

\section{Superfamily ANOMIACEA Family ANOMIIDAE}

\section{Genus ANOMIA Linné, 1758}

Shell thin, partially attached, foramen in right valve, left valve with three muscle scars on central area.

The left (upper) valve of Anomia has one large and two small muscle impressions; the same valve of Pododesmus has one large and one small muscle impression.

Geologic range.-Jurassic to Holocene (table 3).

Geographic range.-Cosmopolitan, except not in the Arctic and Antarctic.

Habitat.- "The species of this genus are attached to rocks, shells or other objects and often acquire sculpture corresponding to that of the object to which they are attached. Often only upper valves are found *** as fossils, because those become loose and are washed away, whereas the lower valve remains attached $* * *$ the byssal plug of members of this genus apparently corrodes surfaces to which it is attached and as a result the shell often lies sunk into a pit of its own making." (Hertlein and Grant, 1972, p. 223).

The animals arrange themselves in the plane of least resistance, thus indicating the direction of strongest current. (Jackson, 1890, p. 354 ).

Intertidal zone to $130 \mathrm{~m}$ in the eastern Pacific (Bernard, 1983, p. 27).

\section{Anomia inornatus (Gabb)}

Plate 6, figure 2; plate 7, figure 3

Placunanomia inornata Gabb, 1864, p. 217, pl. 32, figs. 288, 288a. Arnold, 1909 [1910], p. 108, pl. 3, figs. 1, 10. Arnold and Anderson, 1910, p. 70, pl. 25, figs. 1, 10. Anderson and Hanna, 1925, p. 190.

"Placunanomia" inornata Gabb. Stewart, 1930, p. 66, pl. 8, fig. 4. Pododesmus (Monia) inornatus (Gabb). Vokes, 1939, p. 57-58, pl. 3, figs. 6, 7, 9, 11 .

Original description.- "Shell thin, irregular, inequivalve; upper valve convex, usually narrowest near the beaks, broad towards the base; hinge-margin thickened; surface marked by fine radiating lines; hinge-line but little, if at all, thickened; foramen small, bordered on one side by a thickened margin."

Holotype.-Missing and presumed lost. ANSP 4442 is here designated the lectotype (Stewart, 1930, p. 66, pl. 8, fig. 4).

Type locality.-Corral Hollow [T. 3 or 4 S., R. 3 E., Tesla quadrangle, Alameda County], Calif. Domengine Formation, Eocene.

Supplementary description.- "Recent collections from Corral Hollow have furnished abundant material representing Gabb's species. Among the specimens is a right valve through the byssal notch of which projects a portion of a somewhat calcified byssus. There is a single prominent muscle-scar on the disk. The valve embraces but does not join about the foramen, which is bordered posteriorly by the ventral buttress of the posterior ligamental platform. The right valve is flattened; the left moderately to well inflated. The umbos are prominent, and there is a well developed cardinal area.

"The Domengine specimens show a range in coarseness of sculpturing which fully embraces both Gabb's and Hanna's species. The interior of Anomia mcgoniglensis is not sufficiently well known to allow determination of its true generic position." (Vokes, 1939, p. 58)

"The cardinal area is wide and the ligamental attachment was presumably beneath this platform in the umbos." (Stewart, 1930, p. 66, pl. 8, fig. 4)

Comparison.-According to Vokes $(1939$, p. 58) the sculptural variation of $A$. inornatus is sufficient to include $A$. mcgoniglensis, based on

TABLE 3.-Geologic and geographic distribution of the genus Anomia in the eastern Pacific region

$[\mathrm{H}=$ Holocene; $\mathrm{Pl}=\mathrm{Pliocene} ; \mathrm{M}=$ Miocene; $\mathrm{O}=$ Oligocene; $\mathrm{E}=$ Eocene $]$

\begin{tabular}{|c|c|c|c|c|c|c|c|}
\hline \multirow[t]{2}{*}{ Species } & \multirow[t]{2}{*}{ Oregon } & \multicolumn{3}{|c|}{ California } & \multicolumn{2}{|c|}{ Baja California } & \multirow{2}{*}{$\begin{array}{l}\text { Central } \\
\text { or South } \\
\text { America }\end{array}$} \\
\hline & & Northern & Middle & Southern & Norte & Sur & \\
\hline \multicolumn{8}{|l|}{ Genus $A$ nomia } \\
\hline 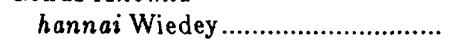 & $\cdots \cdot$ & $\cdots \cdot$ & $\mathrm{O}$ and $\mathrm{M}$ & $\cdots .$. & $\cdots .$. & $\cdots \cdot$ & $\cdots .$. \\
\hline 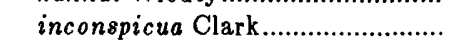 & $\cdots \cdot$ & $\cdots \cdot$ & $\mathrm{M}$ ? & $\cdots \cdot$ & 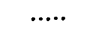 & $\cdots \cdots$ & 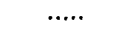 \\
\hline 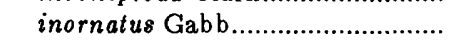 & $\cdots .$. & $\cdots \cdot$ & $\mathrm{E}$ & $\cdots \cdots$ & $\cdots .$. & $\cdots \cdots$ & $\cdots .$. \\
\hline peruviana Orbigny.............................. & $\cdots$. & $\cdots .$. & $\mathrm{H}$ & $\mathrm{M}$ or $\mathrm{Pl}$ to $\mathrm{H}$ & $\mathrm{H}$ & $\mathrm{Pl}$ to $\mathrm{H}$ & $\mathrm{H}$ \\
\hline subcostata Conrad ............................. & ..... & ..... & $\mathrm{M}$ and $\mathrm{Pl}$ & $\mathrm{M}$ or $\mathrm{Pl}$ & ..... & ..... & ..... \\
\hline vaquerosensis Loel and Corey..... & ..... & ..... & $\mathrm{O}$ and $\mathrm{M}$ & $\mathrm{O}$ and $\mathrm{M}$ & ..... & .... & $\cdots \cdot$. \\
\hline $\begin{array}{l}\text { Genus Anomia? } \\
\quad \text { mcgoniglensis M.A. Hanna........... }\end{array}$ & $\mathrm{E}$ & $\cdots .$. & $\cdots .$. & $\mathbf{E}$ & ..... & $\cdots .$. & ..... \\
\hline
\end{tabular}


that character alone, but the lack of a well preserved interior of $A$. mcgoniglensis leaves its generic allocation in doubt.

Geographic range.-Middle California.

Geologic range.-Eocene.

Occurrence in California.-Domengine Formation (Stewart, 1930).

\section{Anomia hannai Wiedey}

Plate 5, figures 4, 5

Anomia hannai Wiedey, 1929b, p. 280-281, pl. 31, fig. 1 .

Original description. - "Shell quite large, not thick, subovoid, rather convex near beak, flattened toward basal margin, more pointed and angular in umbonal area; surface sculptured by about ten coarse, low, irregularly radiating ribs, which tend to split; interior surface irregular, deep in vicinity of beak; ligamental pit apparently broad, deep, but not high. Height, $67 \mathrm{~mm}$.; breadth, $57 \mathrm{~mm}$.; thickness, single valve, $18 \mathrm{~mm}$."

Holotype.-CAS/SU 514.

Type locality.-SU 449. Monterey County, Calif. Vaqueros Formation, Oligocene and Miocene.

Comparison.- - The fewer ribs and larger form serve to distinguish this new species from Anomia peruviana d'Orbigny, living in the Gulf of California. A. hannai is more triangular and less gibbose than the average form of A. subcostata Conrad of the Carrizo Creek beds, lower Pliocene in age, of Imperial County, California." (Wiedey, 1929b, p. 281)

Anomia hannai is higher in proportion to length than $A$. vaquerosensis. The two species are so similar otherwise that additional material may very well show them to be conspecific.

Geographic range.-Middle California.

Geologic range.-Oligocene and Miocene.

Occurrence in California.-Oligocene and Miocene: Vaqueros Formation (Wiedey, 1929b).

\section{Anomia vaquerosensis Loel and Corey}

Plate 5, figure 7; plate 6, figures 9, 12

Anomia vaquerosensis Loel and Corey, 1932, p. 203-204, pl. 33, figs. 1a, $1 \mathrm{~b}, 2 \mathrm{a}, 2 \mathrm{~b}, 3,4$.

Original description. - "Shell thin, medium size, subtrigonal, longer than high, inequilateral, of a silvery-nacreous platy material; left valve moderately inflate [inflated] flattening outwardly, umbone [umbo] strongly inflate with inconspicuous beak twisted to posterior; distinct notch in posterior dorsal margin, rest of periphery irregularly crenulate though evenly rounded. Shell is folded or fluted from umbone to ventral margin posterior to middle and ornamented by about eight narrow irregular and discontinuous crenulations which become stronger and divergent outwardly, annulations very irregular. Hinge margin is thickened, strongly incurving, roughened; interior of shell uneven, ligament pit covered directly under beak, triangular in shape. Muscle scar area is above the center and inclined anteriorly; major byssal adductor scars in a vertical line, minor byssal scar below and to anterior, below which is the smallest byssal scar. Right (attached, or lower) valve not found whole. Length, $57 \mathrm{~mm}$.; height, 50 mm."

Holotype.-UCMP 31758.

Type locality.-UC A-336. Ventura County, Calif. Vaqueros Formation, Oligocene and Miocene.

Supplementary description. - "Other specimens are three times the size of the one described. The species is very irregular in shape because of its habit of attached growth. In many specimens the outline and inflation of beak is almost brachiopod-like, usually with deep radial folds as well as a varying number of plications (usually 6-8).***It is easily identifiable by its thin, silvery shell even when incomplete and should be recognized as one of the best of Vaqueros index fossils. Anomia vaquerosensis, $\mathrm{n}$. sp. has frequently been reported as 'Ostrea sp. " (Loel and Corey, 1932, p. 204)

Comparison.- "Anomia vaquerosensis is distinct from any of the few described North American species." (Loel and Corey, 1932, p. 204) See also Anomia hannai Wiedey described above.

Geographic range.-Middle and southern California.

Geologic range.-Oligocene and Miocene.

Occurrence in California.-Oligocene and Miocene: Vaqueros Formation (Eaton and others, 1941; Durham, 1968; Dickinson, 1969; Squires and Fritsche, 1978).

\section{Anomia inconspicua Clark}

\section{Plate 6, figure 8}

Anomia inconspicua Clark, 1918, p. 133, pl. 13, figs. 19-20.

Original description.- "Shell small, thin, subcircular and somewhat variable in outline; beaks inconspicuous, subcentral in position, on some specimens slightly twisted but on others not; left valve convex; right valve flat, with a large byssal notch. Surface smooth except for rather heavy, irregular incremental lines. Muscle area, as seen on left valve, with one fairly large, distinct scar which is slightly posterior to the beak; other scars indistinct. Hinge line very thin, with a small, deeply sunken resilifer."

Holotype.-UCMP11205.

Type locality. - UC 1131. Contra Costa County, Calif. San Ramon Sandstone, Miocene(?).

Comparison. - "This species appears to be quite distinct from anything described from the West Coast. Possibly the form that is nearest is Anomia linatula [limatula] Dall, from which it differs in being much smaller, in the hinge not being so heavy, and in lacking the faint radiating lines seen on the latter." (Clark, 1918, p. 133)

Geographic range.-Middle California.

Geologic range.-Miocene(?).

Occurrence in California.-Miocene(?): San Ramon Sandstone (Clark, 1918).

\section{Anomia subcostata Conrad}

Plate 6, figures 7, 10, 13; plate 7, figure 5; plate 8, figure 1

Anomia subcostata Conrad, 1855, p. 267. Conrad, 1857b, pl. 5, fig. 34. Conrad, 1857e, p. 161, pl. 19, figs. 1a, 1b. GD. Hanna, 1926a, p. 460, pl. 23, figs. 3-5. Grant and Gale, 1931, p. 241.

Original description.-_ "Obtusely ovate from base to back; lower valve thick, with interrupted somewhat tubercular radii; upper valve thin, radii obsolete or wanting. Height, $1 \frac{112}{2}$ in."

Lectotype.-USNM 1865 is here designated the lectotype (pl. 6, fig. 7). The holotype was cited previously (Keen and Bentson, 1944, p. 25) as USNM 13345a. Two specimens are numbered USNM 13345a (pl. 6, figs. 10,13) but neither of these specimens agrees with Conrad's two illustrations. The lectotype agrees very well with the specimen illustrated by Conrad (1857b, pl. 5, fig. 34), but not with the other specimen illustrated by him (Conrad, 1857e, pl. 19, figs. 1a, 1b). The line drawing (Conrad, 1857b, pl. 5, fig. 34) shows the same breaks in the shell and the same radial sculpture as is seen on the lectotype.

Type locality.-[Carrizo Creek], Colorado Desert, [Imperial Countyl, Calif. Imperial Formation, Miocene or Pliocene.

Supplementary description.- "Obtusely ovate, rather thick; umbo of larger valve ventricose; hinge thickened, surface of the valve obtusely undulated concentrically, and marked with waved, wrinkled, interrupted ribs, much raised, except towards the base, where they are larger and somewhat tuberculiform; upper valve entire, or with 
obsolete radii towards the base." (Conrad, 1857e, p. 161, pl. 19, figs. 1a, 1b)

"Among this large number [100] there is exhibited great variation in shape, sculpture and weight. The radial sculpture ranges from very decided ribs to none at all ***" (G D. Hanna, 1926a, p. 460)

Geographic range.-Southern California.

Geologic range.-Miocene and Pliocene.

Occurrence in California.-Miocene or Pliocene: Imperial Formation (Grant and Gale, 1931); Miocene and Pliocene: Etchegoin Formation (Smith, 1912).

\section{Anomia peruviana Orbigny}

Plate 6, figures 1, 4, 6

Anomia peruviana Orbigny, 1846, p. 673. Grant and Gale, 1931, p. 240 pl. 12, figs. 2, 5. Olsson, 1961, p. 177, pl. 24, figs. 2-2f. Hertlein and Grant, 1972, p. 223-224, pl. 40, fig. 2; pl.41, fig. 8. Keen, 1971, p. 101, fig. 223.

Original description.- “Coquille presque arrondie, un peu carrée plus longue que large, tres-deprimee, marquee en dessus de quelques indices de cotes rayonmantes peu prononcees, nombreuses. Sa couleur est verdatre tres-pale ou rosée; son interieur est verdatre, le ligament entierement vert. La valve inferieure a ses bords desunis sur une grande largeur. Diametre, 33 millimetres."

Holotype.-BM(NH).

Type locality._Paita, Peru. Holocene.

Supplementary description.-- "Recent specimens of Anomia peruviana vary in shape and in sculpture. They may be smooth exteriorly or they may bear well developed radial ribs occasionally bearing very short spines. Exterior sculpture of the shell of Anomia may simulate that of the object to which it is attached. Partly because of the multiplicity of forms resulting from such situs this species has received a number of names in the literature. The following are generally considered to be synonyms: Anomia hamillus Gray, A. larbas Gray, A. alectus Gray, A. lampe Gray, A. pacilus Gray, 'Anomya' simplex Mabille." (Hertlein and Grant, 1972, p. 224)

Geographic range._-Living: middle California to Paita, Peru; fossil: southern California to Ecuador

Geologic range.-Miocene or Pliocene through Holocene.

Occurrence in the Californias.-Miocene or Pliocene: Imperial Formation (C. L. Powell, oral commun., 1983) Pliocene: Almejas (Minch and others, 1976) and Infierno (McFall, 1968) Formations; Pliocene and Pleistocene: Fernando (Soper and Grant, 1932) and Saugus (Waterfall, 1929) Formations; Pleistocene: unnamed strata in southern California (Valentine, 1960), and in Baja California Sur (Emerson, 1980).

Habitat.- "Common on clam shells and rock off exposed beaches along the open coast." (McLean, 1978, p. 71)

"*** lives in quiet bays where it is attached to rocks or to empty shells by a byssus which extends through a notch in the lower valve. The pearly upper valves, which may be white, green or yellow, are often found upon the beaches where the species occurs. The lower valves often are not found, or occur but sparsely among empty shells. This is probably a result of the method of attachment." (Hertlein and Grant, 1972, p. 224). Intertidal zone to $130 \mathrm{~m}$ (Bernard, 1983, p. 27).

\section{Genus ANOMIA?}

\section{Anomia? mcgoniglensis M. A. Hanna}

Plate 5, figures 1,3

Anomia mcgoniglensis M. A. Hanna, 1927, p. 278, pl. 31, figs. 1, 2, 5, 7. Turner, 1938 , p. 46 , pl. 6, figs. 4-6. Weaver, 1942 , p. 100, pl. 22, figs. 4,5 .
Original description.- "Shell of medium size and thickness, only moderately inflated, slightly distorted, shape varying from ovate to elongate, of irregular outline; surface striated by rough, prominent, concentric growth lines and scales; whole surface radially sculptured by many ribs; radial ribs are rounded, slightly nodulose where crossed by growth lines, vary in direction due to distortion of the shell, separated by regularly concave shallow interspaces which vary in size about like the ribs; surface of the inner margin irregular, smooth; muscle scar very large, central, and just below the beak.

Dimensions. - Cotype No. 31011: Altitude $29 \mathrm{~mm}$., length $34 \mathrm{~mm}$., diameter $9 \mathrm{~mm}$. Cotype 31012 : Altitude $30 \mathrm{~mm}$., length $28 \mathrm{~mm}$., diameter $9 \mathrm{~mm}$."

Syntypes.-UCMP31009-31012.

Type locality._UC 3981. San Diego County, Calif. Delmar Formation, Eocene.

Comparison.-Anomia? mcgoniglensis differs from A. inornata (Gabb) in the coarser sculpturing, both concentric and radial. (M. A Hanna, 1927, p. 278)

Vokes $(1939$, p. 58) said that the range in coarseness of sculpture of Anomia inornatus (Gabb) is sufficient to include A.? mcgoniglensis, but the lack of well preserved interiors made generic allocation uncertain.

Geographic range.-Oregon; southern California.

Geologic range. - Eocene.

Occurrence in California.-Eocene: Delmar Formation (M. A. Hanna, 1927; Givens and Kennedy, 1976).

\section{Genus PlaCUNANOMIA Broderip, 1832}

With about three strong radial plications; byssal foramen obsolete in adult; interior with one retractor scar.

Geographic range.-Eastern and western North America; western Central America.

Geologic range.-Miocene through Holocene (table 4).

\section{Placunanomia granti Hertlein}

Plate 6, figure 3

Placunanomia granti Hertlein, 1928, p. 148, pl. 23, figs. 7-9. Loel and Corey, 1932, p. 204, pl. 33, figs. 5, 6a, 6 b.

Original description. - "Shell moderately small, subcircular in outline, inequivalve, compressed. Upper valve slightly convex; surface irregularly wrinkled. Lower valve slightly concave, sculpture similar to right. A short depressed groove is present on the beak. Altitude, 34 $\mathrm{mm}$.; length, $29 \mathrm{~mm}$."

Holotype.-CAS 4139.

Type locality. CAS 1150. Santa Barbara County, Calif. Vaqueros Formation, Oligocene and Miocene.

Comparison.- - This small and rather irregularly faintly plicated species does not resemble closely any other west coast Placunanomia. It does not show the radial striations of $P$. californica Arnold and is smaller and more corrugated than P. hannibali Jordan and Hertlein." (Hertlein, 1928, p. 148)

Geographic range.-Southern California.

Geologic range.-Oligocene and Miocene.

Occurrence in California.-Oligocene and Miocene: Rincon Shale (Avila and Weaver, 1969) and Vaqueros Formation (Hertlein, 1928).

\section{Placunanomia californica Arnold}

Plate 6, figures 5, 11

Placunanomia californica Arnold, 1909, p. 75-76, pl. 24, figs. 2, 2a, 3. Grant and Gale, 1931, p. 243. Adegoke, 1969, p. 106, pl. 10, fig. 4. 
TABLE 4.-Geologic and geographic distribution of the genera Placunanomia and Pododesmus in the eastern Pacific region $[\mathrm{H}=$ Holocene; $\mathrm{Ple}=$ Pleistocene; $\mathrm{Pl}=$ Pliocene; $\mathrm{M}=$ Miocene; $\mathrm{O}=$ Oligocene]

\begin{tabular}{|c|c|c|c|c|c|c|c|c|c|}
\hline \multirow[t]{2}{*}{ Species } & \multirow[t]{2}{*}{ Alaska } & \multirow{2}{*}{$\begin{array}{c}\text { British } \\
\text { Columbia }\end{array}$} & \multirow[t]{2}{*}{ Washington } & \multirow[t]{2}{*}{ Oregon } & \multicolumn{3}{|c|}{ California } & \multicolumn{2}{|c|}{ Baja California } \\
\hline & & & & & Norther n & Middle & Southern & Norte & Sur \\
\hline \multicolumn{10}{|l|}{ Genus Placunanomia } \\
\hline californica Arnold............................ & $\cdots \cdots$ & $\cdots \cdots$ & $\cdots .$. & $\cdots \cdots$ & $\cdots \cdots$ & $\mathrm{M}$ and $\mathrm{Pl}$ & $\mathrm{Pl}$ & $\cdots \cdots$ & $\cdots \cdot$. \\
\hline 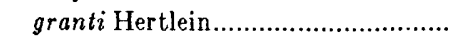 & $\cdots \cdots$ & $\ldots$. & $\ldots .$. & $\ldots .$. & $\cdots \cdot$ & $\cdots \cdot$ & $\mathrm{O}$ and $\mathrm{M}$ & $\cdots \cdot$ & $\cdots \cdot$ \\
\hline hannibali Jordan and Hertlein..... & $\cdots \cdots$ & $\cdots$. & $\ldots .$. & $\cdots .$. & $\ldots \ldots$ & $\cdots \cdots$ & $\cdots \ldots$ & $\cdots .$. & $\mathrm{Pl}$ \\
\hline \multicolumn{10}{|l|}{ Genus Pododesmus } \\
\hline Subgenus Monia & & & & & & & & & \\
\hline macroschisma (Deshayes)......... & $\mathrm{H}$ & $\mathrm{H}$ & $\mathrm{H}$ & $\mathrm{H}$ & $\mathrm{H}$ & $\mathrm{M}$ to $\mathrm{H}$ & $\mathrm{Pl}$ to $\mathrm{H}$ & Ple to $\mathrm{H}$ & $\mathrm{H}$ \\
\hline
\end{tabular}

Original description.-_Shell averaging about 65 millimeters in length, subcircular in outline, inequivale [inequivalve], compressed. Right valve irregular, somewhat convex, the surface sculptured by numerous small, thread-like, rugose, radiating ridges and several laminae of growth; byssal foramen, though closed, leaves an oblique semicovered pit near the beak; two strong elevated rough crests-the auricular crura-diverge from the beak at a very acute angle; immediately behind the auricular crura is the broadly V-shaped scar of the byssal muscle, on each side of which is a deeply impressed groove, and in the middle of which is an oblique V-shaped pit which was once connected with the external pit forming the byssal foramen; adductor scar subcircular to irregular and equal in diameter to over one-third the length of shell. Left valve flat to slightly concave; surface sculpture similar to but less prominent than that of right valve; a broad Vshaped socket, into which the crura of the right valve fits, occupies the area below the beaks; adductor scar same as in right valve.

"Dimensions._Altitude $66 \mathrm{~mm}$.; latitude $60 \mathrm{~mm}$.; diameter of both valves 33 together, $17 \mathrm{~mm}$."

Holotype.-USNM 165546 (right valve).

Type locality.-USGS 4715. Kern County, Calif. Etchegoin Formation, Miocene and Pliocene.

"This rare shell, of which the type, paratype, and a fragment are the only specimens so far known, is characterized by the elevated auricular crura of the right valve and V-shaped socket of the left. Its external sculpture is quite similar to certain specimens of Pododesmus (Monia) macroschisma Deshayes, found Recent and fossil on the Pacific coast. The only other member of the genus Placunanomia on the Pacific coast is the Recent P. cumingi Reeve, of the Recent Gulf of California province, which is characterized by one or two very strong plications. P. californica is thinner and more nearly circular in outline than P. plicata Tuomey and Holmes, of the upper Miocene of the Carolinas; it also has radial sculpture, which is lacking in the latter." (Arnold, 1909, p. 75-76)

Comparison.- "This rare species differs from $P$. cumingii in the presence of radial riblets and the very low, almost obsolete plications. $P$. hannibali Jordan and Hertlein is very closely related, but has finer radial sculpture and the byssal scar is not sub-triangular as in Arnold's species." (Grant and Gale, 1931, p. 243)

Geographic range.-Middle and southern California.

Geologic range.-Miocene and Pliocene.

Occurrence in California.-Miocene and Pliocene: Etchegoin Formation (Arnold, 1909); Pliocene: San Joaquin Formation (Adegoke, 1969).

\section{Placunanomia hannibali Jordan and Hertlein}

Plate 7, figures 2, 6, 7; plate 8, figures 2, 5

Placunanomia hannibali Jordan and Hertlein, 1926b, p. 443-444, pl. 28, figs. 2-4. Grant and Gale, 1931, p. 243. Smith, 1984, p. 206, pl. 205 , figs. 2,3 .

Original description.- "Shell large, thin, subcircular to suboval in outline, usually very flat, compressed and more or less regular in growth; most specimens with no evidence of radial plication but a few more or less profoundly, radially plicate; surface sculptured by concentric growth lines, and by very fine, wavy, minutely prickly, radial striations. Right valve slightly arched; byssal foramen closed or nearly so, but leaving an elongate oblique semi-triangular pit near the beak, which almost communicates with the interior; auricular crura very strong, diverging from the beak at an acute angle varying somewhat in different specimens. Left valve flat or concave, never convex as is the right; without byssal foramen, but usually broken slightly at the beak; interiorly with two strong ribs radiating from the umbo, but fitting outside of the auricular crura," and hence diverging at a somewhat greater angle. Length $114 \mathrm{~mm}$.; width $95 \mathrm{~mm}$.; thickness $15 \mathrm{~mm}$."

Holotype.-CAS 2110.

Type locality.-CAS 945. Baja California Sur. Almejas Formation, Pliocene.

Comparison.- -Placunanomia hannibali is related to $P$. californica Arnold *** but is distinguished by having a generally flatter and more regular shell with very fine rather than heavy radial sculpture. $P$. cumingii Broderip, from the recent fauna of western Mexico and the upper Pliocene of Maria Madre Island is very strongly radially plicate, and lacks all radial sculpture. $P$. hannibali is most nearly related to $P$. lithobleta Dall, of the Miocene of the Caribbean region, but seems to attain a larger size than that species, and to be fitted with larger and heavier auricular crura." (Jordan and Hertlein, 1926b, p. 443-444)

"This species is closely related to $P$. californica Arnold, but $* * *$ appears to attain a larger size and the byssal scar does not have the subtriangular shape of the type of californica."(Grant and Gale, 1931, p. 243)

Geographic range.-Baja California Sur.

Geologic range.-Pliocene.

Occurrence in Baja California Sur.-Pliocene: Almejas (Minch and others, 1976), Gloria (Wilson and Rocha, 1955), and Infierno (Wilson and Rocha, 1955) Formations. 


\section{Genus PODODESMUS Philippi, 1837}

Sculpture of irregular corrugations; shell attached, byssal foramen large, small, or even obsolete; left valve with one large and radially striate byssal retractor scar.

Pododesmus "***differs from Placunanomia in possessing an open byssal foramen in the lower valve, although small or sealed over in the type species, and in lacking large, well developed cardinal crura. It differs from Anomia in possessing only one muscle impression (in addition to the byssal impression), rather than two." (Hertlein and Grant, 1972, p. 225)

Geographic range.-North and South America, Europe, Australia, and Japan.

Geologic range.-Eocene(?); Oligocene through Holocene (table 4).

\section{Subgenus MONIA Gray, 1850}

Byssal retractor scar large; foramen of moderate to large size. The shell of Monia differs from Pododesmus (Pododesmus) "in possessing a large byssal opening and in that the large perforation of the lower valve only slightly embraces the large thin plug." (Hertlein and Grant, 1972, p. 225)

Geographic range.-New Zealand, North America, and Europe. Geologic range.-Oligocene through Holocene.

\section{Pododesmus (Monia) macroschisma (Deshayes)}

\section{Plate 7, figure 4; plate 8, figures 4, 7; plate 9, figure 7}

Anomia macrochisma Deshayes, 1839, p. 359. (Specific name later emended by Carpenter, fide Keen, 1971, p. 103).

Pododesmus (Monia) macroschisma (Deshayes). Arnold, 1903, p. 116-117. Hertlein and Grant, 1972, p. 225-226, pl. 40, fig. 3; pl. 41, figs. $9,12,13$.

Monia macroschisma Deshayes. Arnold, 1909, p. 134, pl. 14, fig. 1. Vedder and Moore, 1976, pl. 1, fig. 3.

Pododesmus macroschisma (Deshayes). Grant and Gale, 1931, p. 241-242, pl. 12, figs. 3, 4a, 4b. Adegoke, 1969, p. 106

Placunanomia cepio Gray, 1850. Kern, 1973, p. 74.

Pododesmus (Monia) cepio (Gray, 1850). Keen, 1971, p. 103, fig. 227.

Pododesmus cepio (Gray, 1850). McLean, 1978, p. 71-72, fig. 39.3.

?Pododesmus newcombei Clark and Arnold, 1923, p. 141, pl. 21, figs. 3-6.

Original description.-"Testa irregulariter ovata, inaequivalvi, albo-viridula, irregulariter plicata; valvaii superiore convexa, inferiore plana, suprene late perforata, foramine integro, marginibus acutis plicatis, valvis intus submargaritaceis, superiore maculamagna satirata viridi ornata." (macroschisma)

"Scars 2, far apart; upper very large, ovate, longitudinal, central; lower smaller, oblong, oblique, rather behind the upper *** Plug large, flat, broad. Notch large wide." (cepio)

Holotype.-Location unknown; of cepio, $\mathrm{BM}(\mathrm{NH})$

Type locality. - "Kamtschatka;" of cepio, California.

Supplementary description.- - The thickness of the shell and the development of coarse or fine radial sculpture (occasionally obsolete) varies greatly depending upon the situs." (Hertlein and Grant, 1972, p. 226)

Authors have most recently separated $P(M$.$) macroschisma as the$ Pododesmus living in the north and western Pacific and $P$. (M.) cepio as the southern species. Pododesmus cepio has been distinguished from P. macroschisma chiefly on the basis of a thinner shell, sculpture, and a larger byssal foramen. Hertlein and Grant (1972, p. 226) stated that "the variation in a large series is so great that there appear to be no criteria to rely upon for separating the shells *** unless certain forms are arbitrarily selected to represent various species. *** Burch, after studying a large series of specimens of Pododesmus from Puget Sound and from Monterey, California, stated that he could find no basis for the recognition of more than one species." On the basis of these statements, I have synonymized $P$. cepio.

Geographic range.-Living: Japan; Alaska to Baja California Sur; fossil: middle California to Baja California Norte.

Geologic range.-Miocene to Holocene.

Occurrence in the Californias.-Miocene: Pancho Rico (Durham and Addicott, 1965) and Santa Margarita (Addicott and Vedder, 1963) Formations; Miocene and Pliocene: Etchegoin (Adegoke, 1969) and Towsley (Kern, 1973) Formations; Pliocene: Careaga Sandstone (Woodring and Bramlette, 1950), Niguel (J. G. Vedder, written commun., 1978) and San Diego (Hertlein and Grant, 1972) Formations and unnamed Pliocene strata on San Clemente Island (Vedder and Moore, 1976); Pliocene or Pleistocene: Fernando (Arnold, 1907c) and Potato Harbor (Weaver and Meyer, 1969) Formations; Pliocene and Pleistocene: Merced (Arnold, 1909; Glen, 1959), Pico (Waterfall, 1929), and Saugus (Kew, 1924) Formations; Pleistocene: San Pedro Formation (Eaton, 1928), Timms Point Silt Member, San Pedro Formation (A. Clark, 1931), and unnamed strata in Southern California and in Baja California Norte (Valentine, 1960).

Habitat.-Common on shells of abalone, submerged reefs, breakwater rocks, and inside dead shells (Smith and Gordon, 1948, p. 170; McLean, 1978, p. 72). Intertidal to 90 m (Bernard, 1983, p. 27, 28 ).

\section{Superfamily LIMACEA Family LIMIDAE Genus LIMA Bruguière, 1797}

Subtrigonal, higher than long, with rather short hinge margin; auricles relatively well differentiated, anterior one slightly the smaller; anterior umbonal ridge not strongly marked; inflation only moderate; gapes of valve margins only slight; hinge edentulous or with weak denticles near ends of hinge margin; ornament of scaly radial ribs.

"Many species are superficially alike and the external ornamentation may vary with habitat. Useful distinguishing characters are found in the comparative height of the umbones and the length of the cardinal area just below the beaks." (Bernard, 1979, p. 31)

Geographic range.-Cosmopolitan.

Geologic range.-Triassic to Holocene (table 5).

Habitat. - “*** most often found in deep and cold waters. Individuals are able to move and sometimes swim, by pulsating the extremely long tentacular fringe of the mantle edges. More usually, species are byssally attached, often in 'nest' of matted byssal threads that may serve as a protection for the exposed tissues and delicate shell." (Bernard, 1979, p. 31)

According to Purchon (1977, p. 149) Lima lima is byssally attached under boulders and has a heavily built shell whereas Lima fragilis, which can swim, has a small, fragile shell. Thus, the thickness of the shell of fossil limids may indicate whether they lived byssally attached or were free moving.

\section{Subgenus LIMA \\ Lima (Lima) vedderi Moore \\ Plate 10, figures 1, 3}

Lima vedderi Moore, 1977, p. 277, figs. 2, 6, 7, 9, 10. 
Original description.- "The shell of Lima vedderi is moderately thick, and the preserved part bears 20 prominent slightly rounded ribs that are separated by rounded interspaces about half as wide as the ribs of the anterior and posterior margins, but as wide as the ribs on the central part of the shell. Assuming a normal positioning of the beaks, the holotype is about $45 \mathrm{~mm}$ high and $50 \mathrm{~mm}$ long. Distinctive bulbous nodes are preserved along the entire length of the surface of the ribs; no part of the ribs is smooth. The nodes are massive and shaped like very shallow cups with their dorsal surfaces convex and smooth and their ventral surfaces concave. The nodes are about evenly spaced; the distance between the mid-points ranges from 2.2 to 2.8 $\mathrm{mm}$. Although the general configuration of the nodes is regular, some nodes are more nearly semispherical and thicker than others. No minor sculpture similar to that on $L$. vedderi has been noted on any described Lima, nor, for that matter, on any other pelecypod genus. The uniqueness of the sculpture makes identification of even small fragments feasible. The outline, shape, and ribbing of $L$. vedderi are sufficient to make assignment to the genus Lima reasonably certain. Holocene specimens of Lima tetrica Gould from Baja California, the only similar northeast Pacific species, ${ }^{* * *}$ differs from $L$. vedderi in sculpture; the ribs on L. tetrica bear spines and lamellae rather than nodes."

Holotype.-USNM 240060.

Type locality._USGS M3220. Orange County, Calif. Monterey Shale, Miocene.

Geographic range.-Southern California.

Geologic range.-Miocene.

Occurrence in California.-Miocene: Monterey (Moore, 1977) and Santa Margarita (Addicott and others, 1978) Formations and unnamed Miocene strata on San Clemente Island (Moore, 1977).

\section{Genus ACESTA H. and A. Adams, 1858}

Large, thin-shelled, ovate, inequilateral, with moderate byssal gape; anterior umbonal ridge ill defined; anterior auricle reduced; ligament pit broad, curved. Cardinal area narrower than that of Lima s.s.

Geologic range.-Jurassic through Holocene (table 5).

Geographic range.-Cosmopolitan.

Habitat.-Living in cold water or at great depths (to 2,550 m).

\section{Subgenus ACESTA}

Sculpture of superficial, rather irregular, radiating riblets that are more strongly developed on anterior and posterior portions of valves.

Geographic range.-Living: California to Chile. Hertlein (1952) described a new species of Acesta collected off California between 1260 and $1465 \mathrm{~m}$ from Mulberry Seamount, thus extending the northern range of the genus.

The scarcity of collections from deep water no doubt directly relates to the known geographic distribution of living Acesta as well as fossil species. (Vokes, 1963, p. 75)

\section{Acesta (Acesta) multiradiata (Gabb)}

Plate 10, figures 5, 8

Lima multiradiata Gabb, 1869, p. 201-202,pl.33, fig.101. Stanton,1896, p. 1038, pl. 63, figs. 7, 8. Dickerson, 1914, p. 151, pl. 8, fig. 1. Stewart, 1930 , p. 125 , text fig. 2.

Original description.- "Shell (right valve) large, oblique, compressed subelliptical; anterior side forming a regular curve to the middle of the base, very slightly sinuous above, under the ear; posterior portion of the basal margin much more narrowly rounded than in advance, uniting by a broad curve above, with the posterior side, the upper half of which seems to have been nearly straight; the anterior ear seems to have been long and narrow. Surface convex a little behind the middle, the anterior slope being broad and nearly flat; the entire surface covered by very numerous, slightly wavy, somewhat irregular,

TABLE 5.-Geologic and geographic distribution of the genera Lima, Acesta, Limaria, Limatula, and Limea? in the eastern Pacific region

[H=Holocene; $\mathrm{Ple}=$ Pleistocene; $\mathrm{Pl}=$ Pliocene; $\mathrm{M}=$ Miocene; $\mathrm{E}=$ Eocene; $\mathrm{Pa}=\mathrm{Paleocene}$

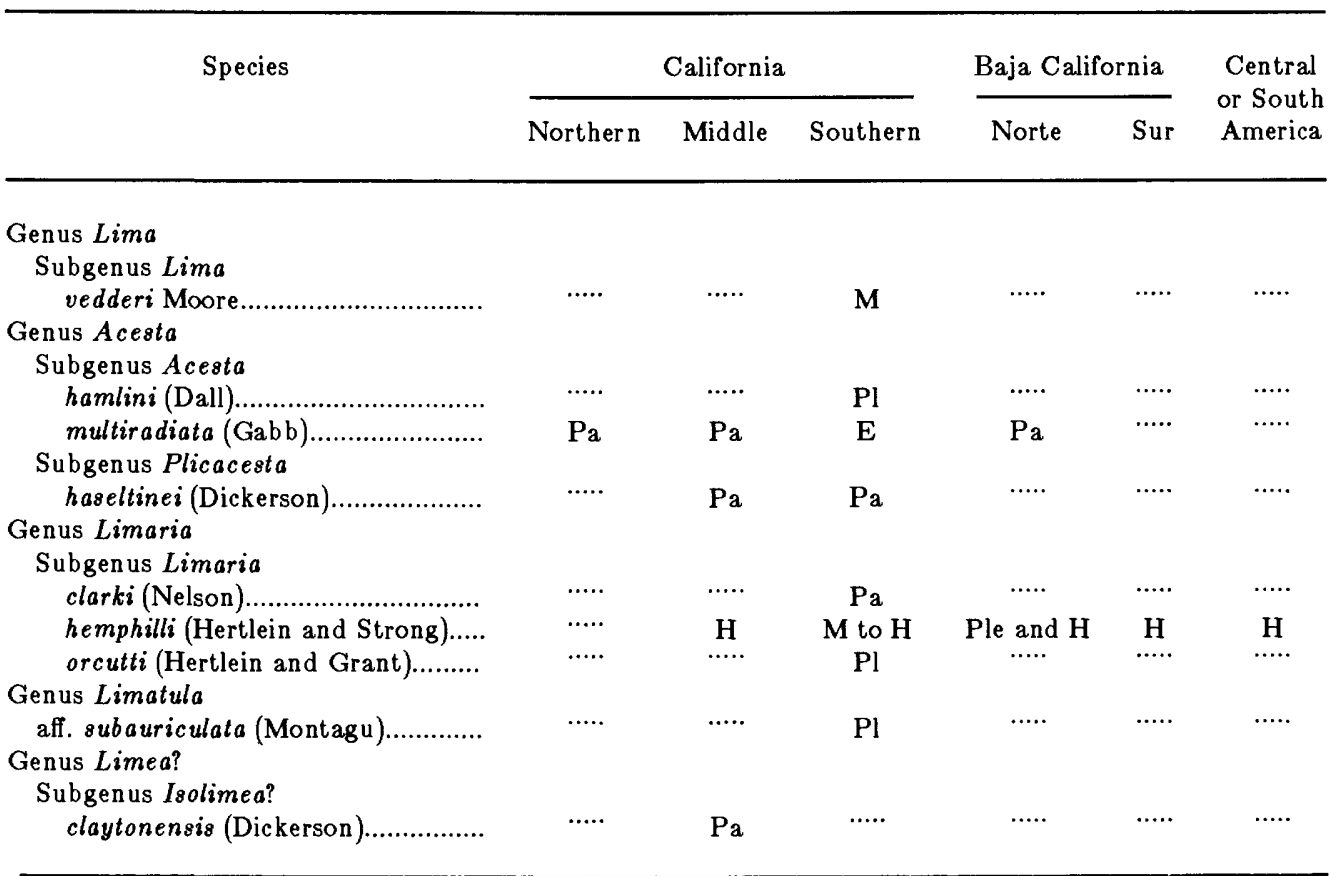


radiating ribs of small size, and with narrow interspaces; on the younger portion of the shell, the spaces between the ribs are mere impressed lines, the ribs being convex; near the base, however, the ribs become proportionally smaller, the spaces are wider than the ribs, and are concave, and the whole are crossed by minute subsquamose lines of growth."

Holotype.-MCZ15016.

Type locality. -Near Lower Lake Village [NE1/4, sec. 11, T. 12 N., R. 7 W.], Lake County, Calif. Martinez Formation, Paleocene.

Supplementary description.- - The holotype *** is very poorly preserved. The right margin is unknown and the left dorsal region has been worn away while the ventral margin is entirely broken away. Unfortunately, the growth lines are not well exposed so that it is impossible to obtain the true outline of the shell. It has been possible to expose part of the left side, showing that the shell is more convex than the original figure suggests. The radial ribs are irregular and somewhat wavy." (Stewart, 1930, p. 125)

Geographic range.-Northern California to Baja California Norte.

Geologic range.-Paleocene and Eocene.

Occurrence in the Californias.-Paleocene: Martinez (Weaver, 1905; Dickerson, 1914) and Sepultura(?) (Gardner in Darton, 1921) Formations; Eocene: Tejon Formation (Stanton, 1896; Arnold, 1906).

\section{Acesta (Acesta) hamlini (Dall)}

\section{Plate 10, figures 4, 7}

Lima hamlini Dall, 1900, p. 16. Arnold, 1907a, p. 527. Dall, 1925, p. 18, pl. 29 , fig. 6 .

Lima (Acesta) hamlini Dall. Woodring, 1938, p. 47-49, pl. 8, figs. 5, 7,10, 11.

Original description.- - "Several specimens, more or less crushed, of a large Lima are among the forms collected. This species belongs to the general type of Lima excavata Fabr., L. goliath Sby, etc., and reaches to a length of four and a half inches. The valves are brilliantly polished, and in the middle part unsculptured, the anterior and posterior thirds are finely radially grooved with shallow grooves of which the outer slopes are less steep than the inner; the incremental lines, obsolete elsewhere, appear in the channel of the grooves and cross striate it here and there, giving the effect of obsolete punctation. I may add that close to the impressed area of the shell there are two or three coarser, deeper radial grooves. The species differs from the South Pacific and all other forms of its group known to me in its much finer and more delicate sculpture and brilliant polish. I await more perfect specimens before trying to figure it, but would propose the name of Lima hamlini for the species in honor of Mr. Homer Hamlin C. E., Asst. City Engineer of Los Angeles, who is much interested in the geology and paleontology of the region, and has made valuable studies of the southern California Tertiary. The specimen in hand was kindly forwarded for examination by Dr. R. E. C. Stearns."

Holotype.-USNM 495186.

Type locality.-USGS 3426. Los Angeles County, Calif. Fernando Formation, Pliocene and Pleistocene (from the Pliocene part of the Fernando Formation, John G. Vedder, written commun., 1983).

Supplementary description.- "A giant Lima allied to the modern Panamanian agassizii. Depressed area at anterior end and posterior auricle sculptured with relatively strong radial ribs that are more closely spaced toward the center of the shell, the interspaces being gradually transformed into narrow grooves, microscopically punctuated by concentric threads. On some specimens subdued grooves continue over the central part of the shell, except in the umbonal region, but in most specimens they are absent on a central area of varying width." (Woodring, 1938, p. 47).

Comparison.-Acesta hamlini is higher in proportion to length than Acesta mori (Hertlein), a species living off central California (Hertlein, 1952, p. 379).
Geographic range.-Southern California.

Geologic range.-Pliocene.

Occurrence in California.-Pliocene: upper part of Capistrano (Vedder, 1972) and lower part of Fernando (Arnold, 1907c; Woodring, 1938) Formations.

\section{Subgenus PLICACESTA Vokes, 1963}

Radial ribs strong on the plicate shells, not exclusively surficial as on Acesta, and characteristically they are larger on the middle of the valves than on the valve margins. Cardinal area and ligamental pit similar to Acesta; relatively thin to very thick shelled.

Geologic range.-Eocene through Holocene (table 5).

Geographic range.-Living: Japan and southern California; fossil: Asia, California, and Washington.

Habitat. -90 to $185 \mathrm{~m}$, Japan; 455-550 m, southern California.

\section{Acesta (Plicacesta) haseltinei (Dickerson)}

\section{Plate 9, figure 10; plate 10, figures 10, 11}

Lima(?) haseltinei Dickerson, 1914, p. 126-127, pl. 8, fig. 2; pl. 9, fig. 11. "Lima" haseltinei Dickerson. Woodring in Hoots 1931, p. 92.

Lima perrini Waring, 1914, p. 782-783. Waring, 1917, p. 76-77, pl. 10, figs. 1, 1a, 2.

Original description.- -Shell large, slightly oblique, nearly equivalve, moderately convex; beak prominent, pointed, anterior, prosogyrate; hinge, edentulous, long, straight; ears not markedly set off from rest of shell, the posterior one being the larger; anterior end broadly rounded; posterior, slightly truncated; ventral margin, arcuate; decoration consists of numerous squarish radial ribs with very narrow interspaces." (haseltinei)

"This giant circular lima has a thick shell with nacreous, and outer prismatic layer. The diameter is about $160 \mathrm{~mm}$. The umbones are small and the cardinal margin slopes gradually to the posterior where it becomes rounded and grades into the circular margin below. The beaks are slightly excavated in front, and the margin slopes at a 35degree angle into the rounded anterior margin. The hinge is very thick and has a deep wedge-shaped ligament pit sloping from the interior edge of the shell to the exterior edge at the anterior end of the hinge line. A single large sub-posterior muscle impression marks the interior of the shell. The surface is ornamented by many fine radiating lines, and the prismatic shell layer gives the surface a silken appearance. It belongs to the subgenus Acesta." (perrini)

Holotype.-UCMP 11676; of perrini CAS/SU 303.

Type locality. -UC 1540, Contra Costa County, Calif. Martinez Formation Paleocene; of perrini, Simi Hills $\left[1.6 \mathrm{~km} \mathrm{N.} 68^{\circ} \mathrm{W}\right.$ of Hill 2150 , southwest of Santa Susana, Camulos quadrangle], Ventura County, Calif. Santa Susana Formation, Paleocene (Zinsmeister, 1983).

Dickerson described Acesta haseltinei in May, 1914, and Waring described Acesta perrini in November-December, 1914. Subsequently, Waring (1917, p. 77) believed the two species to be distinct, although he did say that when more specimens were found of each this might be disproven. Because neither specimen is complete, the original outline of each can be misconceived, but on the basis of the holotypes, I can find no characters to separate the two species. It is unfortunate that the specific name haseltinei precedes perrini by a few months as the holotype of perrini is much better preserved.

Both $A$. haseltinei and $A$. perrini have very thick shells; the thick shells may have been a characteristic of fossil representatives of the subgenus Plicacesta and may indicate that they were byssally attached.

Geographic range.-Middle and southern California.

Geologic range.-Paleocene. 
Occurrence in California.-Paleocene: Martinez (Dickerson, 1914; Waring, 1914) and Santa Susana (Zinsmeister, 1983) Formations.

\section{Genus LIMARIA Link, 1807}

Shell medium-sized, ovate, auricles small, subequal; radial ribs fine, not scaly.

Promantellum Iredale differs but little from Limaria, but the valves of Promantellum may be more widely gaping. Submantellum differs from Limaria in the greater inflation of the valves and the lack of any posterior gape. (Hertlein and Grant, 1972, p. 215).

Geologic range.-Eocene through Holocene (table 5).

Geographic range.-Cosmopolitan.

Habitat. - Species of this genus live today in temperate and tropical waters (Hertlein and Grant, 1972, p. 215).

\section{Subgenus LIMARIA}

Somewhat oblique, rather strongly inflated with wide posterior gape; narrow radial riblets.

Geologic range.-Miocene to Holocene.

Geographic range.-Cosmopolitan.

\section{Limaria (Limaria) clarki (Nelson)}

\section{Plate 10, figure 6}

Lima(?) clarki Nelson, 1925, p. 407, pl. 49, fig. 2.

Original description.- "Shell small, moderately oblique, ovate, compressed; beak inconspicuous. Posterior dorsal margin straight; anterior margin slightly convex, rounding evenly into ventral margin; ventral margin rounded, with decrease in curvature toward posterior extremity; character of posterior end unknown. Anterior ear small; posterior ear unknown. Surface of shell with 20 or more rounded radial ribs which are widest spaced in midportion of shell and indistinct toward each margin, spacing uneven in posterior third of shell. Greatest length of shell in type specimen, $12 \mathrm{~mm}$; width, $8.3 \mathrm{~mm}$.

"The type for this species is a cast from which a small portion of the posterior end has been broken."

Holotype.-UCMP 30494.

Type locality._UC 3752. Ventura County, Calif. Martinez Formation, Paleocene.

Comparison.- "Lima(?) clarki can be distinguished from $L .(?)$ claytonensis Dickerson by its obliqueness and finer ribbing. It resembles L. packardi Weaver and Palmer, from which it can be distinguished by its greater elongation and more widely spaced ribbing." (Nelson, 1925, p. 407)

Geographic range.-Southern California.

Geologic range.-Paleocene.

Occurrence in California._-Paleocene: Martinez Formation (Nelson, 1925).

\section{Limaria (Limaria) hemphilli (Hertlein and Strong)}

Plate 7, figure 1; plate 8, figures 3, 6, 8

Lima (Limaria) hemphilli Hertlein and Strong, 1946, p. 66-67, pl. 1, figs. $3,4$.

Lima hemphilli Hertlein and Strong. Kern, 1973, p. 74.

Original description. - "Shell obliquely elliptical equivalve, inequilateral, moderately convex, broadly gaping especially along the anterior dorsal margin, posteriorly narrowly gaping hinge short, anterior ear the larger, pointed and beneath which a notch is present; the maximum width of the anterior margin is above the middle of the shell; between the widest portion and the hinge the margin shows two vague angulations; ventral margin elliptical, posterior margin very gently rounded; the anterior umbonal slope of the valves is gentle, the posterior slope is rather abrupt; valves ornamented by fine irregular radial ribs which are crossed by very fine imbricating lirae; anterior and posterior submargins smooth. Height $23 \mathrm{~mm}$., length $16.4 \mathrm{~mm}$., convexity (both valves) approximately $12 \mathrm{~mm}$."

Syntypes.-CAS 9174, 9174A.

Type locality.-CAS 5955. San Diego, Calif. Holocene.

Supplementary description.-- "The shell gapes a little more on the anterior than on the posterior side." (Keen, 1971, p. 98)

Comparison.-Lima orcutti somewhat resembles L. hemphilli, but it has fewer, coarser, more widely spaced ribs; the hinge plate is relatively broader; and the posterior ear is much less acutely pointed (Hertlein and Grant, 1972, p. 215).

Geographic range.-Living: Monterey Bay, California to Acapulco, Mexico; fossil: southern California to Baja California Norte.

Geologic range.-Miocene to Holocene.

Occurrence in California.-Miocene and Pliocene: Towsley Formation (Kern, 1973); Pleistocene: Palos Verdes Sandstone and San Pedro Sand (Arnold, 1903); unnamed strata in southern California (Valentine, 1956; Kanakoff and Emerson, 1959) and unnamed strata in Baja California Norte (Valentine and Rowland, 1969).

Habitat.-On rock bottoms, 15 to $100 \mathrm{~m}$ (Bernard, 1983, p. 22). In swimming they carry the hinge behind, in the manner of Pecten (Baily, 1950, p. 112).

\section{Limaria (Limaria) orcutti Hertlein and Grant}

\section{Plate 9, figures 4-6, 8}

Lima (Limaria) orcutti Hertlein and Grant, 1972, p. 215, pl. 35, fig. 11; pl. 4936 , figs. 2-5; pl. 57, fig. 10.

Original description.- "Right valve, shell obliquely elliptical in outline, inequilateral, moderately convex; greatest length (anterior-posterior) about halfway between beak and ventral margin, gaping along the posterior dorsal margin; hinge short, oblique, the posterior ear pointed, a shallow sinus immediately below it; the anterior margin nearly straight above, but below it is gently rounded into the ventral margin, the outline of the posterior and ventral margin forms a broad arc; anterior umbonal slope rather steep, the posterior slope rather gentle; the valves are sculptured with about 35 to 40 fine, radial riblets, some vaguely paired, all separated by wider interspaces, ribs and interspaces widest on medial portion of the valve, the whole crossed by fine imbricating lines of growth; hinge elongately triangular, with a broad shallow, triangular ligamental pit, a triangular pit under the posterior ear, a shallow depression under the anterior one; the interior smooth, in some places the external ribbing is visible. Dimensions of holotype: Height (beak to ventral margin) $43 \mathrm{~mm}$, length approximately $35.5 \mathrm{~mm}$ (posterior side imperfect), convexity (left valve) approximately $9.6 \mathrm{~mm}$."

Holotype.-LAM 4509.

Type locality.-LAM 305c. San Diego County, Calif. San Diego Formation, Pliocene.

Comparison.- "This new species bears a general resemblance to Lima hemphilli Hertlein and Strong which now lives in adjacent waters but the new species has fewer, coarser, more widely spaced ribs, the greatest length of the valves (anterior-posterior) is at a point about midway between the beak and the ventral margin rather than above the middle, the hinge plate is relatively broader and the posterior ear is much less acutely pointed.

"The general features of the hinge are more like that of Lima orbignyi Lamy, but the shell of the new species is much more elongated, less inflated and the valves gape posteriorly.

"The general outline of this new species is somewhat like that of Lima auaua Dall, Bartsch, and Rehder, from Hawaii, but the character of the ribbing appears to be quite different." (Hertlein and Grant, 1972) 
Geographic range.-Southern California.

Geologic range.-Pliocene.

Occurrence in California.-Pliocene: Niguel (J.G. Vedder, written commun., 1983) and San Diego (Hertlein and Grant, 1972) Formations.

\section{Genus LIMATULA Wood, 1839}

Small, oval, strongly inflated; auricles small, subequal; margins not gaping; hinge edentulous; sculpture of fine radial riblets, most conspicuous toward center of valves and absent from posterior end.

Geologic range. - Triassic through Holocene (table 5).

Geographic range.-Cosmopolitan.

Habitat.-Most living species in the eastern Pacific are found at depths of 10-350 m, but one species is found as deep as $2,200 \mathrm{~m}$ (Bernard, 1983, p. 23).

\section{Limatula aff. L. subauriculata (Montagu)}

Plate 9, figure 2

Limatula aff. subauriculata (Montagu). Woodring, 1938, p. 49, pl. 8, fig. 6.

Although not positively identified, this species is included because it is the only known fossil representative of Limatula in the Californias. It is described by Woodring (1938) as follows:

"A small moderately elongate valve represents a species of $\mathrm{Lim}$ atula. The sculpture consists of fine radial ribs, slightly roughened by microscopic concentric threads. Two median ribs are heavier than the others and modify the interior outline. On the interior of the lower part of the shell, where the exterior is missing, a narrow midrib lies between the heavy ribs.

"This species is probably the Recent form known as Lima (Limatula) subauriculata (Montagu). Recent shells attain a height of 16.4 millimeters and a length of 10.4 millimeters. They have one to three relatively heavy median ribs that are differentiated by strong interspaces on the interior, even though the ribs are not conspicuously differentiated on the exterior, a characteristic feature of Limatula shown by the fossil."

Geographic range.-Southern California.

Geologic range.-Pliocene.

Occurrence in California.-Pliocene: lower part of Fernando Formation (Woodring, 1938).

\section{Genus LIMEA Bronn, 1831}

Small; cardinal area narrow; hinge with series of short denticles on either side.

Geographic range.-Cosmopolitan.

Geologic range.-Triassic through Holocene (table 5).

\section{Subgenus ISOLIMEA Iredale, 1929}

Suborbicular; sculpture of strong radial ribs with wide interspaces. Geographic range.-Australia; California(?).

Geologic range. - Holocene; Paleocene(?).

\section{Genus LIMEA? Subgenus ISOLIMEA? \\ Limea? (Isolimea?) claytonensis (Dickerson) \\ Plate 10, figures 2, 9}

Lima(?) claytonensis Dickerson, 1914, p. 126, pl. 7, figs. 9a, 9b.

Original description. - "Shell inflated, with radial sculpture; rounded and almost symmetrical. Ratio of length to height about 65 to 1. Beak prominent, acute, and in some specimens compressed. Hinge line short and straight with about twelve small striations perpendicular to hinge line. These striations may be plications within the shell wall, revealed by th [the] breaking away of the inner shell layer. Area, narrowly elliptical and central. Basal margin, rounded. Ribsabout thirteen in number-are acute-angled and beaded; the interspaces are the same in width as the ribs."

Syntypes.-UCMP11720,11721.

Type locality.-UC 1592. Contra Costa County, Calif. Martinez Formation, Paleocene.

Dickerson said that he had four specimens all from shale $30 \mathrm{~m}$ above the base of the Martinez Formation at the type locality.

Geographic range.-Middle California.

Geologic range.-Paleocene.

Occurrence in California.-Paleocene: Martinez Formation (Dickerson, 1914).

\section{Superfamily OSTREACEA}

Stenzel's (1971) classification, in his scholarly volume on the oysters, is generally followed and I have relied heavily upon his work. Revisions reflect subsequent studies of the anatomy and shell characters of oysters by Harold W. Harry (1981, 1983; written commun., 1983, 1984). In the Tertiary of the Californias, 8 genera are represented by 40 species. Only three of these genera have been used by other workers for Tertiary species of oysters in the eastern Pacific. As noted by Stenzel (1971, p. N1095), classification of oysters at the generic level seems extraordinarily difficult and open to divergent opinions. For example, Woodring (1982, p. 607), who based his classification on that of Stenzel's (1971), assigned one Tertiary species of oyster from the La Boca Formation, early Miocene, Panama, to "Hyotissa", and he said that this species, "Hyotissa" tryoni (Gabb), was by no means a typical Hyotissa but might be a link between Pycnodonte and Hyotissa. Harry (in Harry and Dockery, 1983) described two vesicular species of oysters from the Oligocene in Mississippi, and he said that they did not fit well in any of the four subgenera of pycnodontine oysters recognized by Stenzel(1971).

Harry (in Harry and Dockery, 1983) said that the three subfamilies of Ostreidae are more sharply differentiated from each other and from the Pycnodonteinae by the anatomy of their flesh, reproductive habits, and environmental preference than by the characteristics of the highly variable shells.

The classification used here for eastern Pacific Tertiary oysters is preliminary. Future work on large suites of oysters from stratigraphically controlled sections, and study of variation within large collections of single living species, will improve and refine the classifications suggested by me and also improve the utility of oysters as a tool in correlation.

The oysters as a group show a great range of variability within a single species. Among factors causing variation are the substratum to which they are attached, the toppling over of specimens as the shell grows and becomes too heavy for a small, light-weight object to which it has attached, the crowding of individuals versus uncrowding, and even whether the shell grew in sunlight or in shade (Stenzel, 1971, p. N1019). Taking these factors into consideration, it is unwise to propose new specific or subspecific names for oysters based on one or a few specimens, especially if another species of oyster assigned to the same genus has already been described from the same stratigraphic horizon.

\section{Family GRYPHAEIDAE}

Muscle scar subcircular. Posterior adductor muscle orbicular in cross section and placed closer to hinge than to opposite valve margin, ventral border of its insertion on left valve sometimes elevated above general surface of valve. Valves highly unequal in most genera to subequal in others.

Geologic range.-Triassic to Holocene. 
Habitat.-Most genera never form true oyster reefs in which conspecific individuals grow mainly on one another.

\section{Subfamily EXOGYRINAE}

Chomata commonly present, varied; commissural shelf variable, often well defined; chalky deposits not vesicular; umbo of left valve inflated, opisthogyrous, coiled in several planes, right valve flat or nearly so; posterior bourrelet (posteriormost of three divisions of ligamental area) much reduced, commonly merely a narrow ridge.

\section{Genus GRYPHAEOSTREA Conrad, 1865}

Left valve highly convex and capacious; deep umbonal cavity overhung by hinge plate; anterior wall of left valve spirally curved and rising up obliquely or vertically from substratum; angular to spoonshaped shelly claspers growing out periodically from growth squamae of left valve to provide additional attachments. Right valve flat; outline oval to spatulate or triangular; growth squamae simple and spaced regularly apart starting close to umbo. Right valve considerably smaller than left valve, leaving wide (as much as $0.7 \mathrm{~cm}$ ) margin on left valve uncovered in bivalved fossil specimens.

Geographic range.-Worldwide.

Geologic range.-Cretaceous to Miocene (table 6).

\section{Gryphaeostrea aviculiformis (Anderson)}

Plate 19, figures 1, 2, 6

Ostrea aviculiformis Anderson, 1905, p.194-195, pl.13, figs. 3-5. Arnold, 1909 , p. 50, pl. 2, fig. 12. Vokes, 1939, p. 55.

Original description. - "Shell small, very inequivalve, quadrate, oblique, laminated; inferior valve convex and strongly arched; superior valve thin, often concave, and sharply laminated in thin concentric folds; hinge broad and somewhat straight. The surface of the convex valve is marked only by concentric lines of growth. The margin is more or less ragged or irregular."

Holotype.-CAS 21. The type was recovered after the San Francisco fire of 1906 but was considerably broken (Vokes, 1939, p. 55).
Type locality. - West and north of Coalinga [NW1/4, sec. 35, T. $20 \mathrm{~S}$, R. 14 E., Fresno Countyl, California. Domengine Formation, Eocene.

Supplementary description. - "The upper valve *** was strongly laminated, with laminae which were approximately one eighth of an inch apart." (Vokes, 1939, p. 55)

Comments. - The anterior portion of the left valve is auricular and has a terebratuloid sinus. The right valve is operculiform with evenly spaced, thick laminae made up of prismatic shell layers.

Geographic range.-Middle California.

Geologic range.-Eocene.

Occurrence in California.-Eocene: Domengine Formation (Weaver, 1949) and Avenal Sandstone (Vokes, 1939).

\section{Subfamily PYCNODONTEINAE}

Commissural shelf usually well defined, delimited proximally by circumferential curb. Chomata generally present, vermiculate near ligament; divisions of ligamental area of equal size; shell vescicular. Geologic range.-Cretaceous to Holocene.

\section{Genus PYCNODONTE Fischer de Waldheim, 1835 Subgenus PYCNODONTE}

Left valve umbo rising barely above long straight dorsal margin. Auricles present; outline subcircular to semicircular. Radial ribs absent to low, short, and gently undulatory; no. well-defined radial riblets.

Geographic range.-Cosmopolitan.

Geologic range.-Cretaceous to Pleistocene (table 6).

\section{Pycnodonte (Pycnodonte) ynezana (Loel and Corey)}

Plate 11, figures 1, 3, 4, 6

Ostrea eldridgei Arnold. Arnold and Anderson, 1907, pl. 16, fig. 2; not pl. 18, figs. 6a, 6b ( $=$ O. eldridgei $)$. Not Ostrea eldridgei Arnold, $1907 \mathrm{a}$.

Ostrea eldridgei (Arnold) var. ynezana Loel and Corey, 1932, p. 188-189, pl. 11, fig. 3 ; pl. 12, figs. 1a-1c; pl. 13, figs. 1, 2a, 2b.

TABLE 6.-Geologic and geographic distribution of the genera Gryphaeostrea and Pycnodonte in the eastern Pacific region

$[\mathrm{Ple}=$ Pleistocene $\mathrm{Pl}=$ Pliocene; $\mathrm{M}=$ Miocene; $\mathrm{O}=$ Oligocene; $\mathrm{E}=$ Eocene $]$

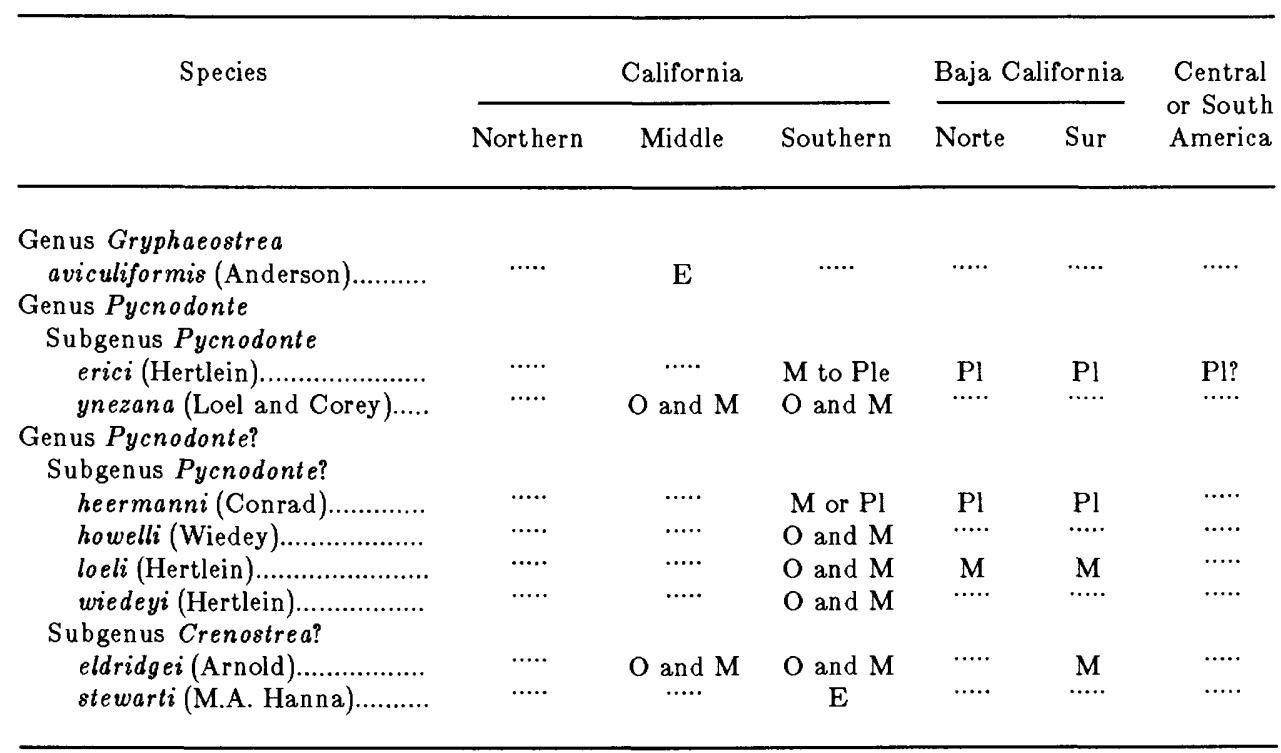


Ostrea eldridgei ynezana Loel and Corey. Addicott, 1965, p. C104, fig. 3f. Crassostrea eldridgei ynezana (Loel and Corey). Addicott, 1973, p. 27, pl. 2, 57 figs. 2, 10. Squires and Fritsche, 1978, p. 19, pl. 3, fig. 5 .

Original description.- - Shell medium, moderately thin; beaks twisted posteriorly; left or lower valve moderately convex, obliquely ovate, irregularly crenulate shell layers smoothly appressed except where protruded as plicated edges; beak pointed; posteriorly extended, margin thin; upper valve concave and foliated. Interior of left valve deep, muscle scar round, central; ligament pit tapering, rounded; upper valve interior convexo-concave with lateral ridges and flat, wide margins, dorsally truncate with deep, round ligament pit. Height, $115 \mathrm{~mm}$.; length, $103 \mathrm{~mm}$.; diameter (thickness through both valves), $40 \mathrm{~mm}$."

Holotype.-UCMP 31745.

Type locality.-UC A-317. At west end of hill that is poorly defined on the topographic map about $0.8 \mathrm{~km}$ northwest of Rancho Atascoso house. $1.9 \mathrm{~km} \mathrm{~S} 80^{\circ} \mathrm{E}$ from 603-ft bench mark on road, Santa Barbara County, Calif. Vaqueros Formation, Oligocene and Miocene.

Supplementary description.- - Specimens of Crassostrea eldridgei ynezana are characterized by their relatively thin valves, the left being moderately convex and somewhat larger than the right. The largest specimen is about $100 \mathrm{~mm}$ in height. During an early stage of growth the axis of the valve undergoes a gradual rotation through about $45^{\circ}$, the result being posteriorly situated beaks and, on many specimens, a subquadrate outline." (Addicott, 1973, p. 27)

Comparison. - "This variety of Ostrea eldridgei is gradational in all characters to $O$. eldridgei Arnold ***.It is characterized by its comparative thinness of valves, lesser convexity of the lower valve and usual crenulation of the margins in a peculiar curtain-like (ruffle) effect. In many specimens the convex valve exhibits strong development of these crenulations, especially toward the margins. The umbones are often blunt or truncate." (Loel and Corey, 1932, p. 190)

"This species is similar to Crassostrea sookensis (Clark and Arnold, 1923, p. 138, pl. 17, figs. 1,2) from the early Miocene(?) Sooke Formation of southern Vancouver Island, British Columbia. The northern species has a thicker shell in general and a less quadrate outline than specimens of C. eldridgei ynezana, but the holotype is too poorly preserved to determine possible relationships confidently." (Addicott, 1973, p. 27)

"The species is differentiated from $O$. howelli by the presence of low, fluted corrugations on the shell, in place of the larger, higher, more angular ribs of $O$. howelli." (Squires and Fritsche, 1978)

Comments. - Although no vesicular shell structure was seen on $P$. ynezana, it is placed in Pycnodonte because it has a long straight hinge line, the dorsal margin is produced into a wing, and the interior of the right valve has a prominent commissural shelf and its exterior bears a few radial gashes.

Geographic range.-Middle and southern California.

Geologic range.-Oligocene and Miocene.

Occurrence in California.-Oligocene: Wygal Sandstone Member, Temblor Formation (Addicott, 1973); Oligocene and Miocene: Vaqueros Formation (Bereskin and Edwards, 1969; Addicott, 1965; Squires and Fritsche, 1978); Miocene: Jewett Sand (Addicott, 1965).

\section{Pycnodonte (Pycnodonte) erici (Hertlein)}

\section{Plate 12, figures 1, 4, 7, 8}

Ostrea tayloriana Gabb. Jordan and Hertlein, 1926b, p. 428, pl. 33, fig. 3. Not Ostrea tayloriana Gabb, 1869.

Ostrea erici Hertlein, 1929, p. 295. Durham, 1950, p. 59, pl. 4, fig. 2. Woodring in Woodring and Bramlette, 1950, p. 85, pl. 8, figs. 17, 18; pl. 9, figs. 1, 3, 4. Hertlein and Grant, 1972, p. 217-218, pl. 38, figs. 4, $6,8,9$.

Original description. - "Shell moderately thick; sub-oval in outline; beaks sub-terminal; ligament pits sub-triangular. Right valve moder- ately convex, shell slopes obliquely from the umbones to the anterior margin, smooth except for projecting edges of shell lamellae; margins of shell rather thin. Left valve moderately heavy, ovate in outline, slightly concave; edges of shell layers give a rather rough appearance to the shell, otherwise without ornament. Height, $94 \mathrm{~mm}$.; width, 71 mm.; thickness, $36 \mathrm{~mm}$."

Holotype.-CAS 2094.

Type locality.-Mouth of large arroyo northwest of Mesa de Elefante, Laguna Scammon [Laguna Ojo de Liebre, fide Woodring, 1950, in Woodring and Bramlette, 1950, p. 85], Baja California Sur. Almejas Formation, Pliocene.

Supplementary description.- "This species is sculptured with lamellae of varying strength. The umbonal part of the shell is thick and composed of numerous shell lamellae. On the attached (left) valve the outer lamellae form a more or less distinct 'wing' adjoining the attachment area. The ligamental groove is narrow and gradually tapering. The inner margin below the ligament area is smooth on large shells and smooth or faintly denticulate on small shells." (Woodring in Woodring and Bramlette, 1950, p. 85)

"Shell moderately large, elongately to roundly trigonal, sometimes slightly expanded posteriorly; lower valve arched, right (upper) valve flat, both valves composed of rather coarse overlapping shell laminae; ligamental pit on both valves elongately trigonal, rather small for the size of the shell; hinge plate at end of pit rounded and very slightly overhanging a shallow cavity; a small flat-topped indentation, corresponding to the lines of growth, occurs on each side of the ligamental pit; interior of shell smooth, large adductor impression rounded to semi-lunar, situated on the posterior side dorsally a little over one half the distance from the ventral margin to to the beak; body cavity often bounded on each side by smooth, steep walls beyond which the shell tapers to a thin edge; margins smooth, no denticles present." (Hertlein and Grant, 1972, p. 217-218)

Comparison.- "No similar Recent species is known in California or adjoining areas." (Woodring in Woodring and Bramlette, 1950, p. 85)

Comments. - The left valve is suboval in outline and the anterior dorsal margin is produced into a wing, with the shell layers folded and projecting upward. The exterior of the left valve is smooth except for paper-thin extensions of the shell laminae that are most noticeable at the margins of the shell. The interior of the left valve body cavity is bounded by a steep shelf posteriorly near the dorsal margin and a less prominent shelf in the same position anteriorly. Vesicular shell structure is visible on the ventral side where the shell is broken or worn.

The right valve is ovate, convex near the dorsal margin and concave near the ventral. The exterior of the right valve is smooth except for radial gashes and imbricated shell lamellae, thinner at the ventral margin and showing thick (as much as $3 \mathrm{~mm}$ ) vesicular layers where broken near the dorsal margin.

Vesicular shell structure is characteristic of the Pycnodonteinae and, on the basis of the prominent commissural shelf, auricle, concentric puckers, and radial gashes, this species is assigned to Pycnodonte.

Pycnodonte erici, which closely resembles $P$. ynezana, differs in that the shell is thicker on $P$. ynezana and markedly produced at the posterior ventral margin. The left valve of the holotype of $P$. ynezana has worn, thick extensions of the shell lamellae that probably were more spoon-shaped than hyote.

Geographic range.-Southern California to Baja California Sur; Mexico? (Hertlein and Grant, 1972, p. 218)

Geologic range.-Miocene to Pleistocene.

Occurrence in the Californias.-Miocene and Pliocene: Sisquoc Formation (Woodring and Bramlette, 1950); Pliocene: Almejas (Minch and others, 1976; Smith, 1984), Boleo (Wilson and Rocha, 1955), Carmen (Durham, 1950), Cebada Member of the Careaga Sandstone and Foxen Mudstone (Woodring and Bramlette, 1950), Gloria (Wilson and Rocha, 1955), Purisima (Cummings and others, 1962), and Niguel (Vedder, 1972) Formations; Pliocene and Pleistocene: Fernando Formation (Willett, 1946). 


\section{Genus PYCNODONTE? Subgenus PYCNODONTE?}

The placement of the species that follow in Pycnodonte? is not based on objective criteria. On the basis of shell characters, it does not seem possible at this time to determine critically where Pycnodonte ends and Hyotissa begins. Harold W. Harry (written commun., 1984) suggested that these thick plicate species might be assigned to Hyotissa? Woodring (1982, p. 607), in describing "Hyotissa" tryoni (Gabb), said that: "This species is by no means a typical Hyotissa but may be a connecting link between Pycnodonte and Hyotissa." On the basis of the specimens that I have examined, I prefer at the present time to assign the species under discussion to Pycnodonte? (Pycnodonte?). The variability of $O$. heermanni in collections from the Imperial Formation, for example, is considerable; some specimens resemble Hyotissa and others Pycnodonte, but more seem to me to resemble Pycnodonte.

\section{Pycnodonte? (Pycnodonte?) howelli (Wiedey)}

\section{Plate 14, figures 1, 3, 5, 7}

Ostrea howelli Wiedey, 1928, p. 135-136, pl. 15, figs. 1, 2. Squires and Fritsche, 1978, p. 19, pl. 2, figs. 1-6; pl. 3, figs. 3, 4.

Original description. - "Shell of moderate size. Variable outline, but most forms exhibit a subcircular to subovoid contour. It is very inequivalve and is seldom equilateral. The left valve is the more convex and thick-shelled. In some specimens the dorsal portion is the narrower part of the shell while the basal end is often wider and more broadly rounded. Umbo of the left valve is found in some individuals to preserve the small subcircular shell of the young stages, showing about six prominent, radiating, irregular ribs as the principal sculpturing. Sculpturing on the adult consists of about six prominently elevated, radiating ridges, separated by narrower channels. Ribs show a tendency to divide at different stages of growth in some specimens. Strong, concentric, incremental growth lines become very coarse toward the basal margin. The interior is smooth with the muscle impression very deep, round, and situated in the posterior portion near the dorsal margin. The ligamental pit is robust, moderately long, roundly and deeply channeled. Length from the margin at the hinge to the distant periphery $90 \mathrm{~mm}$.; breadth, about $60 \mathrm{~mm}$.; thickness of a single valve $40 \mathrm{~mm}$."

Syntypes.-SDNM 26; CAS 2981, 2982; CAS/SU 422 [missing; Keen and Bentson, 1944].

Type locality.-SU and SDNM 446. Ventura County, Calif. Vaqueros Formation, Oligocene and Miocene.

Comparison.- "This new species of Ostrea may not be easily confused with any other known fossil forms because of its very distinctive characteristics. It bears external similarity of outline most closely to Ostrea vespertina Conrad, but the latter species is much thinner shelled. This new form also possesses a much more powerful hinge and greater arching of the shell than Conrad's species. It shows a slight similarity to $O$. titan Conrad and $O$. titan Conrad, var. corrugata Nomland. The latter may be separated by its broader resilial pit relatively smaller muscle impression, and much less prominent sculpture of the shell than found in the new species. Among the living forms there is very little resemblance to this species. So, apparently, it belonged to a group of forms of which there are no, or rare, living representatives." (Wiedey, 1928, p. 136)

"Loel and Corey (1932) synonymized Ostrea wiedeyi with $O$. loeli, but did not note their similarity with $O$. howelli. $O$. loeli was distinguished by a few, low, broadly rounded ribs, $O$. wiedeyi by many, prominent, elevated ribs, and $O$. howelli by a few, prominent, elevated ribs. At localities where specimens are abundant, however, all three forms occur together and are clearly variants of a single species.
"The shell of $O$. howelli is thicker, the hinge is thicker and stronger, and the ligament area longer than in $O$. vespertina." (Squires and Fritsche, 1978, p. 19)

Comments. - No vesicular shell structure preserved; deeply impressed suboval muscle impression. Pycnodonte? howelli somewhat resembles both $P$ ? loeli and $P$ ? wiedeyi but differs from $P$ ? loeli in having a narrower shell with more ribs and from $P$ ? wiedeyi in having a much thicker shell with fewer radial ribs.

Geographic range.-Southern California.

Geologic range.-Oligocene and Miocene.

Occurrence in California.-Oligocene and Miocene: Vaqueros Formation (Carson, 1965; Squires and Fritsche, 1978).

\section{Pycnodonte? (Pycnodonte?) wiedeyi (Hertlein)}

\author{
Plate 15, figures 1, 4, 5, 8
}

Ostrea wiedeyi Hertlein, 1928, p. 147, pl. 23, figs. 1, 10.

Ostrea vespertina Conrad. Avila and Weaver, 1969, pl. 34, figs. 8a, 8b. Not Ostrea vespertina Conrad, 1854.

Original description. - "Shell moderately large, oblong, moderately thick, flattish; surface marked by 10 to 15 deep radiating plications which have a tendency to become nodose, some of the ribs arise at or near the beaks, others branch from the earlier ones or are interpolated between them; interspaces angular; the ribs internally show only toward the margin. Hinge subtriangular, fairly broad, moderately impressed. Muscle scar large, suboval to subquadrate. Altitude 151 $\mathrm{mm}$.; length $69 \mathrm{~mm}$; thickness of lower valve $31.5 \mathrm{~mm}$."

Holotype.-CAS 4129.

Type locality. - CAS 1154. Santa Rosa Island, Calif. Vaqueros Formation, Oligocene and Miocene.

Supplementary description._- "Ostrea wiedeyi is extremely variable from a subovate form ornamented by 12 to 15 radial, nodose plications to a long narrow shell with six to eight plications. The ligament pit also varies with the shape of the shell; in the subovate forms it is a short, turned up triangular pit and in the long shells it is a broad fairly deep and slightly depressed scar. These forms all occur in the same zone and apparently the great variation is due to differences in the swiftness of the water currents in which they grew." (Hertlein, 1928, p. 147)

Comparison.-Pycnodonte? wiedeyi ${ }^{* * *}$ differs from $O$. heermanni Conrad by its elongate form, thinner shell and longer ligament pit. From $O$. howelli Wiedey it differs in being a much larger shell, ornamented by more numerous branching corrugations rather than the few straight corrugations on Wiedey's species.

The small ovate forms of $O$. wiedeyi resemble $O$. vespertina Conrad but the shell usually has a thicker and larger shell and a greater tendency to adopt an elongate form; also the ligament pit in the present species is often quite depressed, narrowly triangular and longer." (Hertlein, 1928, p. 147)

"Ostrea wiedeyi Hertlein $* * *$ bears a strong resemblance exteriorly to $O$. veatchii. The shell of this Miocene species [O. wiedeyi] is much thicker and on some specimens the growth lines loop upward to some extent on each side of the ligamental area. Another feature noticed on the interior of these fossils is the presence of a depression just below the hinge on the posterior side of the body cavity.

"Loel and Corey considered $O$. wiedeyi to be identical with $O$. loeli Hertlein which they placed as a variety of $O$. vespertina. The thick shell, shape of body cavity, and muscle impression, as well as the shape of the hinge line of $O$. wiedeyi bear a greater resemblance to $O$. heermanni than to typical $O$. vespertina. Ostrea wiedeyi bears a close resemblance to Ostrea haitensis Sowerby *** from the late Miocene of Trinidad but the west coast species differs in lacking the transverse vermiculate threads on the margin just below the hinge." (Hertlein and Grant, 1972, p. 220-221) 
Comments. - Vesicular shell structure was not found on the type specimens but other shell characters seem pycnodontine. The holotype (pl. 15, figs. 5,8 ) is a large, spatulate right valve with a thick shell bearing narrow, rounded, dichotomous ribs on the dorsal half. A few of these ribs continue to the ventral margin as wide, low folds of the shell. The ribs on the entire valve seem to have had hyote spines, subsequently broken off.

One paratype (pl. 15, figs. 5,8 ) is a double-valved specimen; the interior is not accessible. The body cavity of the left valve is somewhat larger than the right. Both valves with rounded (at the margins) to knife-shape (on the midportion), irregular, dichotomous, spinose ribs that continue to the shell margins. The commissure is plicate.

The upper (right) valve of Dendostrea? vespertina is flatter than the same valve of $P$.? wiedeyi and bears fewer ribs that are more regular and narrower. Externally the paratype of $P$ ? wiedeyi resembles Hyotissa haitensis (Sowerby) of Woodring (1982, pl. 98, fig. 2)

Geographic distribution.-Southern California.

Geologic distribution.-Oligocene and Miocene.

Occurrence in California.-Oligocene and Miocene: Vaqueros Formation (Hertlein, 1928).

\section{Pycnodonte? (Pycnodonte?) loeli (Hertlein)}

\section{Plate 18, figures 7, 8}

Ostrea loeli Hertlein, 1928, p. 144, pl. 22, figs. $2,3$.

Ostrea vespertina (Conrad) loeli (Hertlein). Loel and Corey, 1932, p. 193-194, pl. 16, figs. 1a, 2; pl. 17, figs. 1a, 1b, 2a, 2b, 3.

Original description.- -Shell quadrate, thick, slightly arched; made up of many layers of shell material; shell shows about 6 coarse, radial, corrugations which are but little developed or absent in the early part of shell but which are pronounced in the adult. Ligament pit broad, prominent, distinctly depressed; body cavity sharply depressed on one side; muscle scar large, depressed, situated on posterior side of shell about one third the length of shell from ventral margin. Height, $130 \mathrm{~mm}$.; length, $100 \mathrm{~mm}$.; thickness, lower valve, $38 \mathrm{~mm}$."

Holotype.-CAS 4117.

Type locality.-CAS 1153. Santa Rosa Island, Santa Barbara County, Calif. Vaqueros Formation, Oligocene and Miocene.

Comparison.- "This heavy oyster resembles Ostrea heermanni Conrad from the Pliocene of Imperial County, California but it is more quadrate in outline, thicker, and it possesses fewer and heavier plications which are prominent only on the ventral part of the shell; it also has a distinctly depressed body cavity and longer hinge line." (Hertlein, 1928, p. 144)

" $O$. loeli Hertlein is a less common variant in the Vaqueros horizon which differs from $O$. wiedeyi Hertlein mainly in degree of sharpness of plications. It may be considered to be of varietal value. Most specimens of the latter form show the six primary plications on the younger part of the shell. 'O. loeli Hertlein,' in retaining these into the adult form, shows a tendency toward O. heermanni Conrad (1885) of the Lower Pliocene." (Loel and Corey, 1932, p. 194)

"Loel and Corey considered $O$. wiedeyi to be identical with $O$. loeli Hertlein which they placed as a variety of $O$. vespertina. The thick shell, shape of body cavity, and muscle impression, as well as the shape of the hinge line of $O$. wiedeyi bear a greater resemblance to $O$. heermanni than to typical O. vespertina." (Hertlein and Grant, 1972, p. 220-221)

Comments. - No vesicular shell structure was found on the type, but other shell characters are pycnodontine. See also Pycnodonte? howelli above.

Geographic range.-Southern California to Baja California Sur.

Geologic range.-Oligocene and Miocene.

Occurrence in the Californias.-Oligocene and Miocene: Rincon Shale (Avila and Weaver, 1969) and Vaqueros Formation (Dickinson,
1966; 1969; Vedder, 1973); Miocene: Comondu (Mina, 1956), Topanga (J.G. Vedder, written commun., 1978) and Tortugas (Minch and others, 1976) Formations.

\section{Pycnodonte? (Pycnodonte?) heermanni (Conrad)}

Plate 13, figures 1, 4, 6, 7; plate 14, figure 4; plate 16, figure 4; plate 17 , figs. 6,7

Ostrea heermanni Conrad, 1855, p. 267. G D. Hanna, 1926a, p. 467, pl. 22 , figs. 7,8 ; pl. 23, figs. $1,2$.

Ostrea veatchii Gabb, 1869, p. 60-61, pl. 17, figs. 21-21a. Not Ostrea veatchii Gabb, 1869, p. 34-35, pl. 11, fig. 59.

Original description.- "Very irregular in form, thick, ovate and often dilated; lower valve shallow; exterior very irregular, with large distant angular radiating ribs and with pits, irregular cavities; cartilage pit broad and oblique; upper valve flat or concave, with a profoundly irregular surface. Length, 5.75 inches; height, 6.5 inches."

Holotype.-ANSP 13367 (Woodring, 1938, p. 46); 4 specimens in type lot all are numbered 13367.

Type locality.-Colorado Desert, Imperial County, Calif. Imperial Formation, Miocene or Pliocene.

Supplementary description.-- Although this species has not been previously figured, so far as I have been able to determine, there is no mistaking the fact that Conrad had specimens of the only large circular oyster of the Coyote Mountain region. It is excessively abundant in many places and also excessively variable. Uneroded specimens, however, show clearly that it is an irregularly ribbed species." (G D. Hanna, 1926a, p. 467)

Comparison.- "Small shells varying in outline from circular-ovate to ovate-falcate are associated with large specimens of heermanni and some of intermediate size $* * *$ from the lower part of the Imperial Formation. Some of these small specimens (length 37.8 to 44.4 millimeters) have fewer and broader plications than vespertina, but some ovate-falcate specimens (length 27.3 to 40.7 millimeters) are indistinguishable from that form in outline, plication, fluting of the inner margin, and character of the ligament area. The possibility that two species of plicate oysters are represented at this locality seems to be remote. These small specimens indicate that vespertina from the upper part of the Imperial Formation is a form of heermanni and that heermanni should be treated as a nomenclatural variety of vespertina. Nevertheless, it does not seem desirable to unite heermanni with vespertina, for typical heermanni is readily distinguishable from any lot of small oysters from the upper part of the Imperial Formation." (Woodring, 1938, p. 46)

Comments. - A left valve of $P$.? heermanni, collected from the Imperial Formation by Charles L. Powell, U.S. Geological Survey, clearly shows vesicular shell structure on the inside of the valve near the commissure; this structure was not seen on the specimens in the type lot. The shell is thick, mostly smooth with a few irregular subdued plications and a very small attachment area. Two fragments seem to have had auricles, and the largest specimen in the type lot (pl. 13, figs. 6,7 ), a right valve, is produced at the anterior margin. The chomata are vermiculate, the chomatal trough well defined, and the commissural shelf is prominent. These characters combined place heermanni in the subfamily Pycnodonteinae (Stenzel, 1971, p. N1105), yet the species does not fit satisfactorily into any of the described genera in that subfamily.

Geographic range.-Southern California to Baja California Sur.

Geologic range.-Miocene(?); Pliocene.

Occurrence in the Californias.-Miocene or Pliocene: Imperial Formation (G D. Hanna, 1926a); Pliocene: Almejas(?) (Minch and others, 1976), and Infierno (McFall, 1968) Formations and unnamed strata at San Felipe (Hertlein, 1968). 


\section{Subgenus CRENOSTREA Marwick, 1931}

Left valve umbo prominent, rising well above hinge line; no auricles; outline vertical oval; posterodorsal valve margin not geniculate; chomata strong, straight, most not branching; radial ribs short, gently undulatory; many variable prominent concentric puckers and welts.

Geographic range.-New Zealand, California(?).

Geologic range.-Eocene(?); Oligocene and Miocene (table 6).

\section{Subgenus CRENOSTREA?}

\section{Pycnodonte? (Crenostrea?) stewarti (M. A. Hanna)}

Plate 19, figures 4, 7, 8

Ostrea stewarti M. A. Hanna, 1927, p. 276, pl. 28, fig. 1; pl. 29, fig. 3; pl. 30 , fig. 3.

Original description. - "Species of medium size, massive, pyriform to subcircular in outline, beak straight; surface bears only prominent partially overlapping growth scales; one valve nearly flat, the other moderately inflated; hinge area massive; central depression of hinge concave, nearly parallei-sided, much deeper in the convex valve; area to either side of the depression flat, and about equal in width to the depression; just posterior to the hinge the margin is denticulate with narrow sharp teeth, which are separated by round-bottomed interspaces, teeth best developed in the flat valve; adductor scars large, subcircular, nearly central and just below the hinge; adductor in the convex valve located in a deep pit. Dimensions: Altitude from the beak to the ventral $115 \mathrm{~mm}$., length $115 \mathrm{~mm}$., width of the hinge $45 \mathrm{~mm}$., thickness of the shell of the convex valve $30 \mathrm{~mm}$., diameter of the convex valve $50 \mathrm{~mm}$."

Syntypes.-UCMP 30921, 30922.

Type locality._UC 5062. San Diego County, Calif. Rose Canyon Shale (M.A. Hanna, 1926), Eocene.

Comparison.- "The massiveness of the shell, the position and the shape of the adductor scars, and the general character of the hinge may be used to distinguish Ostrea stewarti n. sp. from other West Coast species." (M. A. Hanna, 1927, p. 276)

Comments.-The syntypes are a right and a left valve. Although the valves seem to fit together at the ventral margin, they gape markedly at the dorsal margin and the ligamental areas are widely separated. The left valve is almost ovate, the right valve pyriform. The muscle impressions are large and subcircular and positioned near the ligamental areas. The left-valve muscle impression is in a deep pit, unlike any I have seen on other Eastern Pacific Tertiary oysters. Both valves are thick for their size; the left more so than the right. Chomata are preserved on the right valve; no vesicular shell structure was seen. The left valve may have had a radial posterior sulcus, has no radial ribs, but does have concentric puckers. The exterior shell of the right valve is not preserved.

Geographic range.-Southern California.

Geologic range.--Eocene.

Occurrence in California.-Eocene: Rose Canyon Shale (M. A. Hanna, 1927) and unnamed strata in the Transverse Ranges (Squires, 1977).

\section{Pycnodonte? (Crenostrea?) eldridgei (Arnold)}

Plate 21, figures 1, 4

Ostrea eldridgei Arnold, 1907a, p. 528, pl. 42, figs. 2, 2a. Arnold and Anderson, 1907, pl. 18, figs. 6a, 6b; not pl. 16, fig. $2(=$ O. eldridgei ynezana). Loel and Corey, 1932, p. 188, pl. 11, figs. 1a, 1b, 2. Hertlein and Jordan, 1927, p. 622. Hanna and Hertlein, 1943, p. 174, fig. 63-16. Squires and Fritsche, 1978, p. 19, pl. 4, fig. 1.
Original description. - "Shell about $150 \mathrm{~mm}$. in length, inequivalve, the left very convex, the right flat or slightly concave. Left valve with incurved umbo; a prominent, falcate, evenly convex ridge extends from near the umbo to the margin of the left valve posteriorly; surface of this valve and ridge foliaceous and more or less inclined to be fluted. Left valve approximately flat, with foliaceous surface."

Holotype.-USNM 164966 [erroneously cited as 164968 in Keen and Bentson, 1944].

Type locality.-[Oak Ridge], Elkins Ranch, east of Grimes Canyon, near Fillmore [sec. 7, T. 3 N., R. 19 W., Piru Quad.], Ventura County, Calif. Vaqueros Formation, Oligocene and Miocene.

Supplementary description. - "Ostrea eldridgei Arnold is most variable in thickness and ornamentation. The collections examined indicate the existence of two major forms or variants, often found in association, with perfect intergradation. One or the other form is usually in dominance of numbers in any single zone. Arnold figured both forms, the heavier thicker form, lacking plications or 'frills' was the first figured and the one described by him." (Loel and Corey, 1932, p. 189.)

Comparison. - "This species is distinguished from the other Tertiary oysters of the California Tertiary by the prominent posterior ridge and incurved umbo of the left valve. The species has the external appearance of a Gryphaea." (Arnold, 1907a, p. 528)

Comments. - The shell characters of $P$.? (C?) eldridgei seem pycnodontine, but it is not known if the species has vesicular shell structure. The posterior radial sulcus indicates placement in Crenostrea.

Geographic range.-Middle California to Baja California Sur. Geologic range.-Oligocene and Miocene.

Occurrence in the Californias.-Oligocene and Miocene: Soda Lake and Quail Canyon Sandstone Members of the Vaqueros Formation (Vedder, 1973), Vaqueros Formation (Addicott, 1972; Squires and Fritsche, 1978; Dickinson, 1969); Miocene: Isidro(?) Formation (Hertlein and Jordan, 1927) and Monterey Shale (Weaver, 1949).

\section{Genus HYOTISSA Stenzel, 1971}

Valves similarly sculptured, left valve slightly more convex; attachment area large to very large; commissure plicate in free-growing individuals; ribs crude, irregularly dichotomous, tops mostly rounded and crossed by prominent nonappressed growth squamae.

Noninterlocking, adjacent, vermicular ridges, occurring only near the ligament in both valves, are regularly present in Hyotissa. Hyotissa s.s. may have a few lath chomata below the vermiculate chomata.

For variation within one species of Hyotissa, see $H$. haitensis (Sowerby) figured by Woodring (1982, pl. 98, fig. 2; pl. 103, fig. 7; pl.105, figs. 10,11; pl.109, figs. 6, 9-12)from the Emperador Limestone Member, La Bóca Formation, Miocene, Panama.

Geographic range.-Worldwide.

Geologic range.-Cretaceous to Holocene (table 7).

Habitat.-The genus is euhaline, stenohaline, and stenothermal, a member of the compound-coral biocoenosis (Stenzel, 1971, p. N1108).

\section{Hyotissa hyotis (Linné) \\ Plate 16, figures 1, 2}

Mytilus hyotis Linné, 1758, p. 704, no. 217. Linné, 1767, p. 1155, no. 244. Ostrea jacobaea Rochebrune, 1895, p. 241. Not Ostrea jacobaea Linné, 1758.

Ostrea fisheri Dall, 1914, p. 1, new name. Hertlein, 1957, p. 65-66.

Ostrea fischeri Dall. Durham, 1950, p. 59, pl. 6, figs. 1, 4. Olsson, 1961, p. 173-174, pl. 23, fig. 6 .

Original description.- - M. testa plicata imbricata squamis compressis patulis, labro utroque laevi." (hyotis) 
TABLE 7.-Geologic and geographic distribution of the gener Hyotissa, Neopycnodonte?, Lopha?, and

Dendostrea? in the eastern Pacific region

$[\mathrm{H}=$ Holocene $\mathrm{Ple}=$ Pleistocene $\mathrm{Pl}=$ Pliocene; $\mathrm{M}=$ Miocene; $\mathrm{O}=$ Oligocene $]$

\begin{tabular}{|c|c|c|c|c|c|c|}
\hline \multirow[t]{2}{*}{ Species } & \multicolumn{3}{|c|}{ California } & \multicolumn{2}{|c|}{ Baja California } & \multirow{2}{*}{$\begin{array}{l}\text { Central } \\
\text { or South } \\
\text { America }\end{array}$} \\
\hline & Northern & Middle & Southern & Norte & Sur & \\
\hline $\begin{array}{l}\text { Genus Hyotissa } \\
\quad \text { hyotis (Linné).................... }\end{array}$ & $\ldots .$. & $\ldots .$. & $\ldots .$. & $\ldots .$. & $\mathrm{Pl}$ to $\mathrm{H}$ & $\mathrm{Pl}$ to $\mathrm{H}$ \\
\hline $\begin{array}{l}\text { Genus Neopycnodonte? } \\
\text { cf. cochlear (Poli)......... }\end{array}$ & ..... & ..... & $\cdots \cdot$ & ..... & $\mathrm{PI}$ & $\ldots .$. \\
\hline $\begin{array}{l}\text { Genus Lopha? } \\
\quad \text { Subgenus "Lopha" }\end{array}$ & & & & & & \\
\hline $\begin{array}{l}\quad \text { veatchii (Gabb) } \\
\text { Genus Dendostrea? }\end{array}$ & $\cdots$. & $\cdots \cdot$ & $\mathrm{Pl}$ and Ple & $\mathrm{Pl}$ & Pl & $\cdots .$. \\
\hline 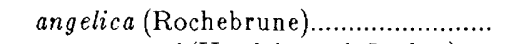 & $\cdots \cdot$ & $\cdots \cdot$ & $\mathrm{M}$ and $\mathrm{Pl}$ & $\mathrm{Pl}$ & Pl to $\mathrm{H}$ & $\cdots \cdots$ \\
\hline angermanni (Hertlein and Jordan)..... & $\cdots \cdots$ & $\cdots \cdots$ & O to Pl? & $\cdots \cdots$ & M & $\cdots \cdots$ \\
\hline 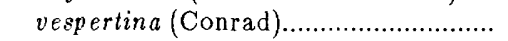 & $\cdots \cdot$ & $\mathrm{M}$ and $\mathrm{Pl}$ & $\mathrm{M}$ and $\mathrm{Pl}$ & $\mathrm{Pl}$ & $\mathrm{Pl}$ & $\mathrm{Pl}$ \\
\hline
\end{tabular}

"Testa sublibera, apice inferiori tantummodo adherens; crassiuscula subrotundata, complanata, ad marginem plicato crenata; umbonibus rectis, abbreviatis, pyramidatis; ligamento elongato, subangustato, longe arcuato; valvis subaequalibus, transverse nodoso undulatis et radiatim late plicato costatis, plicis irregularibus, obscure squamatis, obtusis, interruptis; impressione subcentrali, rotundate evato; extus violacca et sordide luteo tincta; intus albonitida, vel cereo subpurpureoque peruncta; fuscoviolaceo late marginata." (fisheri)

Holotype.-Missing. According to Dodge (1952, p. 206), unmarked specimens of the species are found in the Linnaean collection, but none can be used as the type, because the name hyotis does not appear on Linnés list of owned species, thus raising the probability that the specimens were added later and possibly by someone else. Of Ostrea fisheri, in Muséum Nationale d'Histoire Naturelle de Paris.

Type locality.-In Pelagi Gorgoniis; of fisheri, Îles de la Baie de la Paz.

Supplementary description.- -Shell large (length $120 \mathrm{~mm}$ ), subcircular to obliquely oblong, thick, generally strongly plicated with six or more heavy ribs and sharp folds, heaviest near the margin, similar in both valves. These ribs occasionally develop irregular hollow tubular extensions. *** Adductor scars large, placed slightly posterior of the middle. Cardinal area wide and heavy. Substance of the shell is thick, made up of porcellaneous layers interfingered with porous and cellular seams.

"Typical specimens have a round, thick shell with strong ribs *** Other specimens which have grown attached to smooth piling will have a flat or curved surface and a relatively thin shell without ribs." (Olsson, 1961, p. 173,174)

“*** an extremely variable species, especially in the degree of development of the tubular processes arising from the imbricate layers of the upper valve, and the available figures are confusing in that they usually represent the most highly developed form in this respect, a form that is rarely seen" (Dodge, 1952, p. 206).

Comparison.-Hyotissa quercinus (Sowerby), a species living at Bahía de los Angeles, differs from $H$. hyotis in being smaller with radial plicae rare, small, and local. The left promyal passage is closed in $H$. quercinus whereas it is open in H. hyotissa. (Harold W. Harry, written commun., 1983).

Comments.-Hyotissa hyotis has vesicular shell structure, irregularly dichotomus ribs with hyote spines, and prominent nonappressed growth squamae.
Geographic range.-Living: East Africa and Madagascar to southern Japan; Golfo de California to Ecuador and Galapagos Islands; fossil: Baja California Sur to Mexico.

Geologic range.-Pliocene through Holocene.

Occurrence in Baja California.-Pliocene: Carmen (Durham, 1950). Infierno (Wilson and Rocha, 1955), Marquer (Durham, 1950), and San Marcos (Durham, 1950) Formations and unnamed strata at Rancho El Refugio and Isla Cerralvo (Hertlein, 1966); Pleistocene: Santa Rosalia Formation (Wilson, 1948) and unnamed strata on Isla Carmen (Hertlein, 1957).

\section{Genus NEOPYCNODONTE Stenzel, 1971}

Shell walls very thin, outline variable, many individuals auriculate. Left valve deep and capacious, posterior half rising vertically from substratum attachment so that the hinge axis is at $45^{\circ}$. Left valve mostly smooth but older individuals have paper-thin foliaceous imbrications near ventral margin and some may be drawn out into long hyote or spoon-shaped extensions. Auricles on either side of hinge common, foliaceous, and imbricated. Commissural shelf on left valve only in dorsal half. Adductor muscle imprint large, diameter about one-fourth that of valve height. Right valve flat to concave with a few radial gashes. Commissural shelf on right valve nearly complete around periphery.

Geographic range.-Worldwide.

Geologic range.-Oligocene to Holocene (table 7).

Habitat.-The type species, Ostrea cochlear Poli, is stenohaline and euhaline in oceanic waters of $12-14{ }^{\circ} \mathrm{C}$ and at depths of $27-1500 \mathrm{~m}$. (Stenzel, 1971, p. N1111).

\section{Genus NEOPYCNODONTE?}

\section{Neopycnodonte? cf. N. cochlear (Poli)}

\section{Plate 32, figures 3, 7}

Two specimens were figured by Durham (1950, pl. 5, figs. 4,6) as Ostrea cumingiana Dunker. The specimen illustrated in figure 6 is Dendostrea? angelica (Rochebrune), and it is included herein in that synonymy and illustrated in plate 34 , figure 2 . The specimen Durham (1950) illustrated in figure 4 resembles Neopycnodonte cochlear (Poli, 
1795, p. 179) and is illustrated in plate 32 , figures 3,7 . I have included it to call attention to the probable presence of Neopycnodonte in the eastern Pacific.

Geographic range.-Baja California Sur.

Geologic range.-Pliocene.

Occurrence in Baja California Sur--Pliocene: Marquer Formation (Durham, 1950).

\section{Family OSTREIDAE}

Adductor muscle scar usually concave dorsally or flattened. Chomata of pustules in right valve with or without pits to receive them in left valve. Chomata absent in some genera throughout postlarval life or occasionally in larger specimens of a few genera. Chalk deposit when present not vesicular. Commissural shelf rarely well defined.

\section{Subfamily LOPHINAE}

Attachment area medium size to large; some genera with shelly claspers that grow out at intervals from plicae of left valve to lock onto substrate. Valves subequal, with similar rib patterns of regular, subequal, fairly sharp-crested plicae producing a regularly plicate valve commissure.

Chomata are minute pustules that usually form a moderately broad, usually interrupted submarginal band completely around both valves. Pits to receive the pustules are absent in the opposite valve. The chomata are aligned on the protochomata with none to three on adjacent bands. Other chomata may be present as a single row of pustules in right valve with pits to receive them in left. Chalk deposits are lacking, and there are many chambers. (Harry, 1983, p. 90)

\section{Genus LOPHA Röding, 1798}

Attachment area medium to large. Some species often have shell claspers that grow out at intervals on plicae of left valve to lock onto substrate. Valves subequal in size and convexity with similar rib patterns of regular, subequal, fairly sharp-crested plicae with flat sides which produce a regularly plicate valve commissure.

Geographic range.-Worldwide in the tropics and partly in the subtropics. (Restricted to tropical Indo-Pacific in Holocene.)

Geologic range.-Triassic(?) to Holocene (table 7).

\section{Genus LOPHA?}

\section{Subgenus "LOPHA"}

\section{Lopha? ("Lopha") veatchii (Gabb) \\ Plate 17, figures 1-5}

O[strea] veatchii Gabb, 1866, p. 34-35, pl. 11, fig. 59; not 1869, p. 60-61, pl. 17, figs. 21, 21a [ = Ostrea heermanni Conrad].

Ostrea veatchii Gabb. Heilprin, 1884, p. 316, pl. 72, fig. 1. Hertlein and Grant, 1972, p. 219-221, pl. 39, fig. 4; pl. 40, figs. 1, 4-6.

Ostrea haitensis Sowerby subsp. vespertina Conrad. Stewart, 1930, pl. 14, fig. 4. Not Ostrea vespertina Conrad, 1854.

“Ostrea” veatchii Gabb. Smith, 1984, p. 206, pl. 4, fig. 6.

Original description.-- "Shell large, subequivalve, varying from nearly equilateral to very oblique, the obliquity being always to the left side. Surface marked by ten or a dozen large, angular, radiating ribs, some of which arise at or near the beaks, the others branching from the first, or interpolated between them; the interspaces are angular, and the ribs are marked by more or less squamose plates, and occa- sionally these plates assume almost the character of spines; internally the ribs show only towards the margins. Hinge short, very broad and shallow; no crenulations or denticulations near the margin. Muscular scar large, suboval to subquadrate."

Holotype.-ANSP 4502.

Type locality.-Cerros [Cedros]Island, Baja California Norte. Almejas Formation, Pliocene.

Supplementary description.--"The type is a comparatively thin (about $4 \mathrm{~mm}$ ) lower valve, $75 \mathrm{~mm}$ high and $68 \mathrm{~mm}$ long, the upper anterior margin incomplete. The exterior is sculptured with about 10 angular, radiating ribs which at intervals develop into spines. Interiorly there is no recessed area under the hinge, the muscle impression is fairly large and rounded, and as mentioned by Gabb, there are no denticles along the margin of the valve. An upper valve, about the same size, gently convex, sculptured similar to the type, is in the type lot." (Hertlein and Grant, 1972, p. 220)

Comparison.- "The gently arched upper valve, more numerous, spinose ribs which deeply interlock along the ventral margin and the smooth margins totally lacking denticles are shell characters quite different from those of $O$. vespertina from its type locality.

"Exteriorly some specimens of $O$. angelica bear a close resemblance to $O$. veatchii. *** The shell of $O$. angelica is usually thicker, the flutings usually do not extend to the dorsal third of the valves and do not develop into spines, interiorly the margins below the ligamental pit are finely denticulate, and the muscular impression is semicircular in outline.

"Examination of about 50 specimens from Pliocene strata on Cedros Island, the type locality of $O$. veatchii, and of additional specimens from Bahia Tortolo (Turtle Bay), Lower California, reveals considerable variation. Some of these agree exactly with Gabb's type and lack denticles on the margin. Others, usually smaller, more trigonal or falcate forms have very fine denticulation only along the upper portion of the margin, others have denticulation similar to that on $O$. vespertina. Also occurring at Cedros Island are specimens agreeing in every way with $O$. angelica. The variation in this series from Cedros Island is such as might lead one to question whether perhaps some of these are hybrids between $O$. veatchii and $O$. angelica. For the present we believe it desirable to retain $O$. veatchii as a separate taxon at least until the relationships of west American oysters are better known.

"Ostrea wiedeyi Hertlein described from early Miocene strata on Santa Rosa Island, California, bears a strong resemblance exteriorly to $O$. veatchii. The shell of this Miocene species is much thicker and on some specimens the growth lines loop upward to some extent on each side of the ligamental area. Another feature noticed on the interior of these fossils is the presence of a depression just below the hinge on the posterior side of the body cavity.

"Ostrea veatchii, at times, has been placed in the synonymy of $O$. haitensis Sowerby, a species occurring in strata of Miocene age in the Caribbean region. The west American shell represents a similar but distinct species with a thinner shell and without denticles or transverse threads on the margin." (Hertlein and Grant, 1972, p. 220-221)

Comparison.-Pycnodonte? wiedeyi (Hertlein) is thicker shelled and has more radial plicae, which are not as sharp-crested nor as high as the plicae on $L$.? veatchii, and the hyote spines are smaller.

Comments.-Lopha? veatchii has irregular ribs that are rarely dichotomous, hyote spines on young individuals, and very prominent nonappressed growth squamae.

The specimen (holotype) first described as O. veatchii (Gabb, 1866) and later figured by Gabb (1869, p. 34-35, pl. 11, fig. 59) is thin shelled and moderate in size. It has strong, sharp, radial plicae, some with hyote spines, a plicate commissure, no commissural shelf, and no vesicular shell structure. Because it has lophine characteristics, it is here assigned to Lopha?. Subsequently, Gabb (1869, p. 60-61, pl. 17, figs. 21, 21a) described and figured another specimen (hypotype) that 
he identified as $O$. veatchii. This specimen is a very thick shelled left valve with numerous irregularly placed, rough-topped ribs, a strong commissural shelf, and vesicular shell structure. It is identified here as Ostrea heermanni Conrad, a species that has pycnodontine characters, and is assigned to Pycnodonte?. Hertlein and Grant (1972, p. 220) noted that this specimen resembled $O$. heermanni.

Stewart (1939, p. 128-130) placed $O$. veatchii and $O$. heermanni into synonymy with $O$. vespertina, an example of the difficulty that workers have had differentiating fossil oysters. Ostrea vespertina is assigned here to Dendostrea?. The specimen illustrated by Stewart (1930, pl. 14, fig. 4) as an example of $O$. vespertina is the holotype of $O$. veatchii.

Lopha? veatchii differs from Lopha chiefly by the absence of fine pustules in crowded rows on the extensions of both valves (H. W. Harry, written commun., 1984).

Geographic range.-Southern California to Baja California Sur.

Geologic range.-Pliocene and Pleistocene.

Occurrence in the Californias.-Pliocene: Almejas (Mina, 1957), Cantil Costero (Hertlein and Allison, 1959), Carmen (Durham, 1950), Marquer (Durham, 1950), Niguel (J.G. Vedder, written commun., 1978), San Diego (Hertlein and Grant, 1972) and San Marcos (Durham, 1950) Formations and unnamed strata on Isla Tres Marias (Hertlein and Emerson, 1959); Pliocene and Pleistocene: Fernando (Arnold, 1907c; English, 1914), Pico (Kew, 1924), and Saugus (Kew, 1924) Formations.

\section{Genus DENDOSTREA Swainson, 1835}

Small (as much as $8.5 \mathrm{~cm}$ high); both valves convex, equivalve, shape lanceolate to ovate, usually with many rounded to sharp radial plicae. Surface without any pustules, but with many fine, closely set growth squamae. Hollow recurved hyote spines arise intermittently from crests of plicae of left valve; several of them serve as claspers for left valve embracing stem of coral and gorgonaceans, but clasper spines are usually not present. Dendostrea is highly variable in size, shape, and plications. Usually the marginal commissure is finely zigzag, at least in some sections. Chomata are variable, being ostreine usually, sometimes both ostreine and lophine, and rarely only lophine. (Harold W. Harry, written commun., 1984)

The exterior surface of Dendostrea is never pustular as that of Lopha s.s., and there are no fingerprintlike markings inside as in Alectryonella. Ostreola is about the same size as Dendostrea, but plications are generally present only on the left valve. (Harold W. Harry, written commun., 1984)

Geographic range.-Worldwide. The eastern Pacific Tertiary species are all questionably assigned to Dendostrea.

Geologic range.-Miocene to Holocene (table 7).

Habitat.-Tropical and partly subtropical; usually attached to stony coral, often attached to gorgonians (sea fans).

\section{Genus DENDOSTREA?}

\section{Dendostrea? angermanni (Hertlein and Jordan)}

\section{Plate 31, figures 1-6, 8}

Ostrea angermanni Hertlein and Jordan, 1927, p. 621, pl. 17, figs. 3, 6 . Clark, 1929, p. 21, pl. 19, fig. 3.

Original description.- - Right valve rather small, subquadrate in outline, moderately arched; an unornamented area covers beak and umbonal region, remainder of shell ornamented by 15 to 20 medium fine, well developed radial plications. Interior of valve moderately deep, sloping from margins of shell to point of greatest concavity at center; hinge shows narrow ligament pit running to anterior dorsal edge of shell; dorsal and parallel to this another longer, narrow pit follows posterior dorsal edge of shell; margins of shell marked with small crenulations. Height $46.2 \mathrm{~mm}$.; length $38.9 \mathrm{~mm}$.; greatest diameter of shell $13.1 \mathrm{~mm} . "$

\section{Holotype. - CAS/SU 5137.}

Type locality.-SU 59. Baja California Sur, Isidro(?) Formation, Miocene.

Comparison.- "Ostrea angermanni differs from O. vespertina Conrad in possessing a different hinge in which the pits are narrow and run obliquely across hinge to anterior dorsal margin of shell; furthermore, the present species possesses many more and much finer radial plications on the exterior of the valve. From Ostrea (Alectryonia) plicata Chemnitz and $O$. edulis Linnaeus, $O$. angermanni can be distinguished by the more numerous and finer radial plications ornamenting the right valve. $O$. angermanni differs from $O$. sellaformis var. thomasii Conrad, in that the lower valve of the present species is more quadrate in outline, it is apparently more highly arched and is ornamented by finer ribs." (Hertlein and Jordan, 1927, p. 621)

Comments. - The right valve is very inflated compared to the size of the shell. Although this species seems to belong in the subfamily Lophinae, its characters don't fit well into any of the genera assigned to that subfamily by Stenzel (1971, p. N1157).

Geographic range.--Southern California to Baja California Sur. Geologic range.-Oligocene to Pliocene(?).

Occurrence in the Californias.-Oligocene and Miocene: Vaqueros Formation (Clark, 1929); Miocene: Isidro(?) Formation (Hertlein and Jordan, 1927); Miocene or Pliocene: Imperial Formation (Bramkamp, 1935).

\section{Dendostrea? vespertina (Conrad)}

Plate 11, figures 2, 5; plate 12, figures 2, 5, 6; plate 13, figure 5; plate 14, figure 2; plate 15, figures $2,3,6$, 7; plate 16, figures 6,7

Ostrea vespertina Conrad, 1854 , p. 300 . Conrad, 1857 d, p. 325 , pl. 5 , figs. 36-38. Arnold, 1909, p. 77, pl. 24, figs. 4, 5. GD. Hanna, 1926a, p. 468, pl. 26, figs. 1-3. Grant and Gale, 1931, p. 152, pl.12, figs. 1a, 1b. Woodring, 1938, p. 42-47, pl. 8, figs. 1-4, 89; pl. 9, fig. 5. Woodring in Woodring and Bramlette, 1950, p. 85, pl.16, figs. 4,17. Hertlein and Grant, 1972, p. 218-219, pl. 39, figs. 1-3, 5-9. Addicott in Addicott and Galehouse, 1973, p. 511, 513, fig. 3a-c, h, 1- n.

Ostrea vespertina Conrad var. sequens Arnold, 1909, p. 79-80, pl. 29 , figs. 5, 6. Woodring in Woodring and others, 1940, p. 92, pl. 8, figs. 10-14; pl. 10, figs. $1-5$.

Ostrea haitensis Sowerby subsp. vespertina Conrad. Stewart, 1930, $\mathrm{p}$ 128-130, pl. 14, fig. 4.

Not Ostrea vespertina Conrad. Durham, 1950, p. 59, pl. 5, figs. 1, 2, 5, 7 84 [ = Ostrea angelica Rochebrune].

Original description.- - "Ovato-subfalcate, lower valve plicated or ribbed; hinge long and wide, sharp and somewhat pointed; ligament cavity wide, profound, minutely wrinkled; margins abrupt, cavity not very deep; muscular impressions large, impressed; upper valve flat, irregular; pallial impression crenulated throughout its whole extent, profoundly crenulated on the upper half of the shell. From beak to base $17 / 8$; transversely $1 \frac{1}{2}$. ." (vespertina)

"Shell averaging about $42 \mathrm{~mm}$., in length, subcircular in outline, irregular, plaited, usually with three major plaits, each of these sometimes sulcate or divided into minor plaits; foliaceous lines of growth not as prominent as in many species of Ostrea; beak prominent curved toward right when viewed from exterior. Right valve nearly flat or only slightly folded, the plaits practically obsolete; incremental laminae as in left valve; hinge not strong, subdentate laterally in left valve; muscle scars prominent." (vespertina sequens) 
Lectotype.—Of vespertina ANSP13366 (Woodring, 1938, p. 43); holotype of vespertina sequens USNM 165545.

Type locality. - Of vespertina, near San Diego [Carrizo Creek, Imperial County fide Woodring, 1938, p. 43], Calif. Imperial Formation, Miocene or Pliocene; of vespertina sequens USGS 4728, Kings County, Calif. San Joaquin Formation, Pliocene.

Supplementary description.-_"Left valves are strongly to moderately plicate; right valves are moderately plicate to warped, some small right valves being practically flat. The ligamental groove is shallow, relatively wide, and rapidly tapering. The inner margin below the ligament area is generally strongly denticulate, but is weakly denticulate to smooth, or practically smooth, on a few valves. With few exceptions, the umbo is twisted in a counterclockwise direction when the shells are viewed in attached position." (Woodring, in Woodring and Bramlette, 1950, p. 85)

"The lower valve is usually convex, bearing 5 to 10 plications, and the upper valve is flattish and fits down into the fluting around the margin. The margin below the ligamental area bears denticulations which sometimes occur along the margin for half the length of the valve." (Hertlein and Grant, 1972, p. 218-219)

Comparison.- " $O$. vespertina is smaller, relatively narrower, and usually more falcate in outline and carries plaits more regular in size and generally fewer in number than O. haitensis."(Arnold, 1909, p. 78)

"Perhaps the average Recent specimen [Ostrea palmula Carpenter, 1856] has the upper margins a little more fluted and the excavation under the beak of the lower (left) valve a little deeper but these features are variable in a large series.

"The large oyster from Imperial Co., California, named Ostrea heermanni by Conrad has an ovate, flattish, very thick shell. The body cavity is fairly deep on the anterior side and the exterior flutings are reflected interiorly along the margins of rather thin valves, but not on thick valves. The growth lines are decidedly looped upward on each side of the ligamental area, distinctly different from those of $O$. vespertina which are but slightly or not at all looped upward.

"Some authors have considered a close relationship to exist between $O$. vespertina, $O$. haitensis Sowerby, $O$. heermanni Conrad, and $O$ wiedeyi Hertlein. The latter three species bear a greater resemblance to $O$. veatchii $\mathrm{Gabb} * * *$ Studies of the type lot of $O$. vespertina and other specimens from the type locality, also the selection of a lectotype by Woodring, have furnished a basis for separating this species from typical $O$. veatchii with which it has been united by some authors." (Hertlein and Grant, 1972, p. 219)

Comments. - I have not seen hyote spines or vesicular shell structure on $D$.? vespertina. I place the species in Dendostrea? on the basis of its plicate margin, crude, irregularly dichotomous plicae, and rather large attachment area. Mostly the muscle scar is prominent, rounded medially and pointed peripherally, and distinctly concave on dorsal margin.

Addicott (in Addicott and Galehouse, 1973, p. 510-511) considered Ostrea vespertina sequens to be a small, weakly sculptured form of $O$. vespertina, a decision with which I concur.

Geographic range.-Middle California to Mexico (Hertlein and Grant, 1972, p. 219).

Geologic age.-Miocene and Pliocene.

Occurrence in the Californias.-Miocene: Castaic (Stanton, 1966) and Santa Margarita (Nomland, 1917; Adegoke, 1969; Addicott and others, 1978) Formations; Miocene and Pliocene: Etchegoin Formation (Adegoke, 1969); Miocene or Pliocene: Imperial Formation (G D Hanna, 1926a; Stump, 1979); Pliocene: Almejas (Emerson and Hertlein, 1960), Boleo (Wilson, 1948), Cantil Costero (Hertlein and Allison, 1959), upper part of Capistrano (Kern and Wicander, 1974), Carmen (Durham, 1950), Fernando (Woodring, 1938; Durham and Yerkes, 1964; Vedder, 1972), Gloria (Wilson, 1948), Infierno (Wilson, 1948), Marquer (Durham, 1950); Niguel (Vedder, 1972), upper part of Paso Robles (Addicott and Galehouse, 1973), Pico (Winterer and
Durham, 1958), Purisima (Allen, 1946; Wilkinson, 1963), San Diego (Hertlein and Grant, 1972), San Ignacio (Mina, 1957), San Joaquin (Woodring and others, 1940), San Marcos (Durham, 1950), lower part of Saugus (Squires and White, 1983), and Towsley (Winterer and Durham, 1958) Formations.

\section{Dendostrea? angelica (Rochebrune)}

Plate 32, figures 1, 8, 9; plate 34, figures 2, 7, 9, 10

Ostrea angelica Rochebrune, 1895, p. 241-242. Keen, 1971, p. 82, fig 167. Emerson and Hertlein, 1964, p. 353, figs. 3a-3c. Hertlein and Grant, 1972, p. 216-217, pl. 38, figs. 2, 3.

Lopha angelica (Rochebrune, 1895). Bernard, 1983, p. 24.

?Ostrea cumingiana Dunker. Durham, 1950, p. 58, pl. 5, fig. 6. Not Ostrea cumingiana Dunker, 1846.

Ostrea vespertina Conrad. Durham, 1950, p. 59, pl. 5, fig. 7; not pl. 5, figs. 1, 2, 5. Not Ostrea vespertina Conrad, 1854.

Original description.- "Testa aggregata, plerumque irregulariter ovoideo rotundata, apice plus minusive attenuata, ad marginem undulato dentala; umbonibus arcuatis, ligamento obliquo; valvis inaequalibus; valva inferiore subprofunda, intense adherens, circulariter radiatim costata; costis crassis subangulosis; valva superiore plana, centraliter corrugata, circulariter radiatim costata, costis irregularibus, obtusis plicatis, plicis imbricatis latis; extus albo viridula, intus albo nitida virescente; impressione subcentrali albo, trapezoideo; marginibus lateralibus prope umbonibus, minutissime denticulatis."

Holotype.-In Musée Nationale d'Histoire Naturelle de Paris.

Type locality.-Bahía de Los Angeles, east coast of Baja California Sur. Holocene.

Supplementary description.-- "Recent specimens of $O$. angelica are usually oblong or rounded and the shell is rather thick. The lower valve is decidedly convex, the upper one only gently so. Both valves are sharply plicated over the distal half or one third of their surfaces which interlock along the margin, but the plications usually do not extend much beyond the pallial line on the interior of the valves. ${ }^{* *}$ Denticles or transverse vermiculations are present on the margins from the ligamental pit usually to about a third the distance to the ventral margin. The muscle impression is posterior to the center, trapezoidal in shape." (Hertlein and Grant, 1972, p. 217)

Comparison.- "Small specimens of $O$. angelica differ from $O$. lurida laticaudata Carpenter in the greater thickness of the shell, the more convex upper valve which is more deeply plicated and along the margin interlocks downward with the lower valve rather than turning upward along the margin and fitting into the scalloped margin of the lower valve. Adult shells of $O$. angelica attain a much greater size and thickness than forms of $O$. lurida.

"These same shell characters serve to separate $O$. angelica from $O$. palmula Carpenter, with which it occurs in the Gulf of California.

"The valves of $O$. angelica are generally larger, thicker, and more deeply plicated than those of $O$. vespertina. The plications on the exterior of the valves usually are present only on the distal half or third of the valves of $O$. angelica. On the lower valve these plicae extend from the margin to the broad unplicated area of attachment. The corresponding area of attachment on $O$. vespertina is usually much smaller. Furthermore the upper valve of $O$. angelica is more convex, the plications interlock downward along the margin, whereas on $O$. vespertina the upper valve is almost flat and fits into the scalloped edges of the lower valve similar to that of $O$. lurida laticaudata and $O$. palmula." (Hertlein and Grant, 1972, p. 217)

Comments.-The posterior half of the left valve of Dendostrea? angelica rises vertically from the substrate, a generic character used by Stenzel (1971, p. N1109-N1110) to differentiate the genus Neopycnodonte. In other characters, however, D.? angelica is closest to 
Dendostrea. According to Harold W. Harry (written commun., 1983), its anatomy is distinctly lophine.

Geographic range.-Living: Golfo de California; fossil: southern California to Mexico.

Geologic range.-Miocene or Pliocene to Holocene.

Occurrence in the Californias.-Miocene or Pliocene: Imperial Formation (Stump, 1979); Pliocene: Almejas (Minch and others, 1976), Carmen (Durham, 1950), Infierno (McFall, 1968), Marquer (Durham, 1950), and San Diego (Hertlein and Grant, 1972) Formations; Pleistocene: unnamed strata in Baja California Sur (Durham, 1950) and Mexico (Stump, 1979).

Habitat.-At the mouths of estuaries and bays that are sheltered from breakers but which have a current (Hertlein and Grant, 1972, p. 217). From 1-5 $\mathrm{m}$ and $13-32{ }^{\circ} \mathrm{C}$ (Bernard, 1983, p. 24).

\section{Subfamily OSTREINAE}

Left valve often plicate, right valve usually less so, with much variation among individuals. Chomata are a single band of pustules in the right valve with pits to receive them in the left valve (Harry, 1983, p. 90). Chomata are small, few, generally present in small shells, often absent in larger ones. Chalk deposits usually present, not vesicular. Attachment small to large; no hyote or clasper spines. (Harold W. Harry, written commun., 1983)

As restricted by Harold W. Harry (written commun., 1983), Ostrea s. $s$. includes those species that have smooth surfaces or closely spaced, thin, fragile imbricated lamellae on the flat right valve which has no radial ribs. The left valve has fewer growth rests than the right valve, the lamellae are fewer and thicker and narrower but more elevated.
The left valve has numerous, closely spaced, small radial plicae, more or less continuous at growth rests. The attachment area is small to large.

\section{Genus OSTREA Linné, 1758}

Very compressed circular shells with no plications along valve margins. Chomata often absent in large specimens (Harry, 1983, p. 90). Genus here restricted to those species which have numerous, closely spaced, thin, fragile imbricated lamellae on the right valve. The right valve is flat and lacks radial ribs; the left valve has numerous closely spaced, small radial plicae. Chalk deposits are usually present. (Harold W. Harry, written commun., 1983)

Geographic range.-Eastern Atlantic, Indo-West Pacific, Japan and adjacent Asiatic coast. No species of Ostrea s. s., as here restricted, is known living in the northern hemisphere of the eastern Pacific or western Atlantic. Ostrea edulis (Linné) is present in the eastern Atlantic and Ostrea denselamellosa Lischke is present off Japan and the adjacent asiatic coast. Besides the typical subgenus, a second one, Eostrea Ihering, 1907, is represented by a single living species, $O$. $(E$.) puelchana Orbigny, circum-mundane between $35^{\circ}$ and $50^{\circ} \mathrm{S}$. latitude Adult shells of the two subgenera are practically the same, and only differences in larval form and period of incubation distinguish the two. (Harold W. Harry, written commun., 1983)

Geologic range.-Cretaceous through Holocene (table 8).

Habitat.-In cool, temperate waters, most populations live at a depth of several meters, but a few specimens are found at very low tides. (Harold W. Harry, written commun., 1983) Open sea and bays in salinity of 22-41 parts per thousand (Oyama, 1952, p. 338).

TABLE 8.-Geologic and geographic distribution of the genera Ostrea, Ostreola, "Ostrea," and Acutostrea in the eastern Pacific region

$$
[\mathrm{H}=\text { Holocene; } \mathrm{Ple}=\text { Pleistocene; } \mathrm{P}]=\text { Pliocene; } \mathrm{M}=\text { Miocene; } \mathrm{O}=\text { Oligocene; } \mathrm{E}=\text { Eocene; } \mathrm{Pa}=\text { Paleocene }]
$$

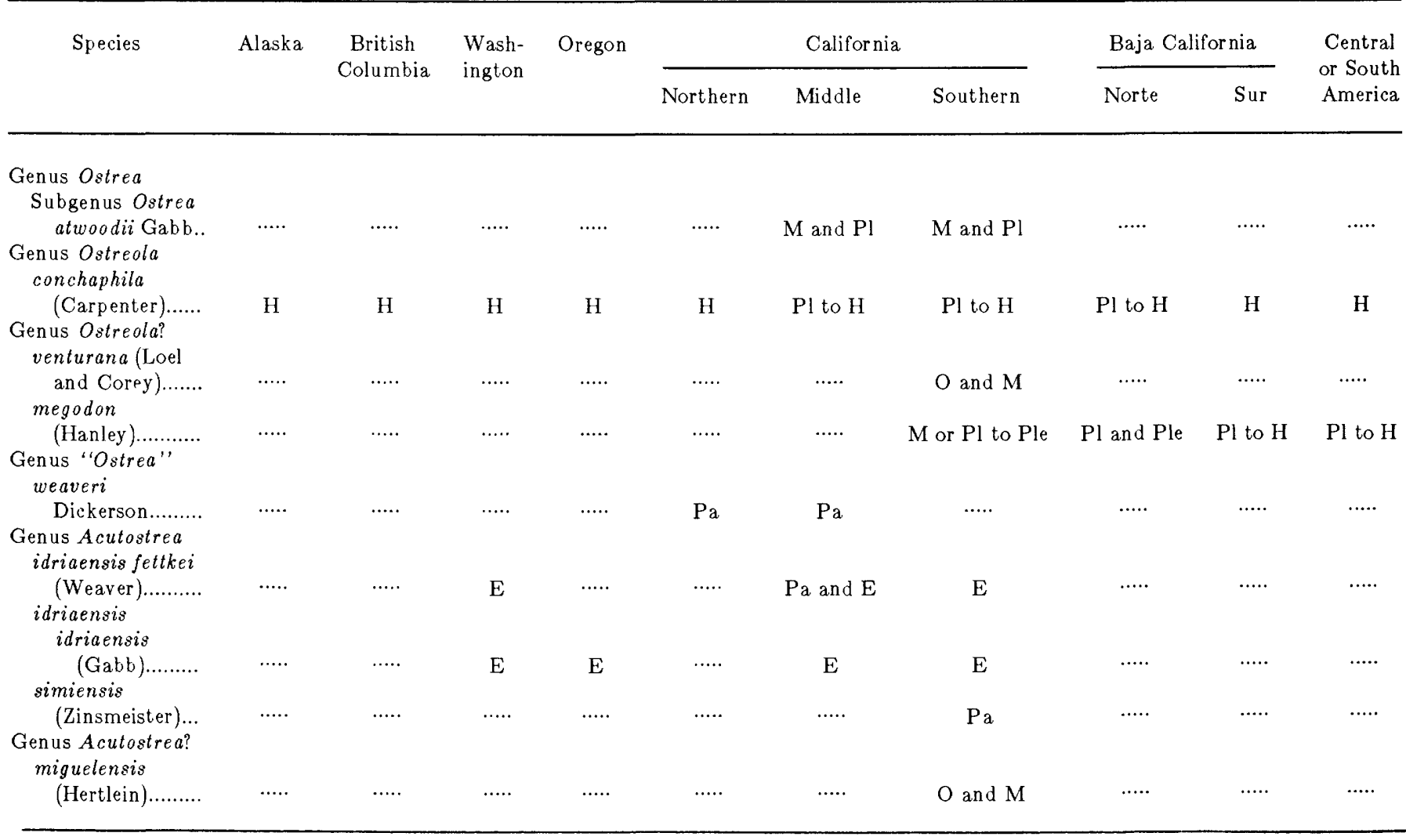




\section{Subgenus OSTREA}

\section{Ostrea (Ostrea) atwoodii Gabb}

\author{
Plate 30, figures 7, 9
}

Ostrea atwoodii Gabb, 1866, p. 33-34, pl. 10, figs. 58, 58a; pl. 11, fig. 58b. Arnold, 1909, p. 140, pl. 17, figs. 1, 2. Woodring in Woodring and others, 1940, p. 92, pl. 29, figs. 1, 13. Durham and Addicott, 1965, p. A13, pl. 3, figs. 3, 7. Addicott in Addicott and Galehouse, 1973, fig. $3 p, r$.

Original description. - "Shell broad, irregular, thin; partly attached, sometimes by nearly the whole of the lower surface; free surface of lower valve marked by numerous irregular radiating ribs crossed by lines of growth; upper valves more squamose and not radiated (in the only specimen I have seen). Hinge broad at the base, triangular, not deep, and sometimes slightly oblique; inner margin of the shell not denticulated. Muscular scar broad."

Holotype.-Missing (Keen and Bentson, 1944).

Type locality.-San Lorenzo Creek, Monterey County, Calif. Pancho Rico Formation, Miocene.

Comments. - The smooth, flat right valve and the finely ribbed left valve serve to distinguish $O$. atwoodii.

Geographic range.-Middle and southern California.

Geologic range.-Miocene and Pliocene.

Occurrence in California.-Miocene: Pancho Rico Formation (Durham and Addicott, 1965); Miocene and Pliocene: Etchegoin Formation (Woodring and others, 1940; Adegoke, 1969); Pliocene: Paso Robles Formation (Addicott and Galehouse, 1973).

\section{Genus OSTREOLA Monterosato, 1884}

Stenzel (1971, p. N1138) placed Ostreola in synonymy with Ostrea. Ostreola is reinstated here and the information concerning the genus was furnished by Harold W. Harry (written commun., 1983).

Shells smaller than those of Ostrea, as restricted herein; generally subcircular to slightly elongate dorso-ventrally. The right valve is flat, or nearly so, without radial plicae, and the prismatic layer is continuous as a smooth sheet with few growth rests from which no lamellae project. Left valve often broadly cemented to substrate, but upturned part usually has prominent plications. Ostreine chomata prominent, extensive, and persistent in older shells.

Geographic range.-Mediterranean and probably southward in the eastern Atlantic at least to the equator; western Atlantic from North Carolina to Argentina; eastern Pacific from Alaska to Panama.

Geologic range.-Oligocene (?); Pliocene to Holocene (table 8 ).

Habitat. -Stenohaline, oceanic salinity. Of the three species known living, two extend from the tropics to the cool temperate zone and the third may have the same range, but its distribution is poorly known. Occasionally found at very low tide level, but optimum populations are found subtidally at a depth of a few meters.

\section{Ostreola conchaphila (Carpenter)}

Plate 30, figures 1-4, 6, 8

Ostrea conchaphila Carpenter, 1857, p. 161-163. Palmer, 1958, p. 66 [see for synonymy].

Ostrea lurida Carpenter, 1864, p. 645. Arnold,1909, p. 167, pl. 30, fig. 12. Oldroyd, 1924, p. 50, pl. 37, figs. 10a, 10b. Howard, 1935, pl. 7, fig. 5. Palmer, 1958, p. 66-67, pl. 5, figs. 4-6. Hertlein, 1959, p. 6-7, pl. 2, figs. 1-3, 6-9, 11 .

Original description. - "O.t. plerumque parvâ, tenui, subovali, testis variis affixâ; purpurea saepe aurantiâ tinctâ, interdum radiis unâ vel duabus; cardine parvo, utroque latere denticulis crenato; areâ ligamenti augustà, triangulari, saepius sulco denticulato utràque parte extus ornatâ; plerumque totá valvá affixá, margine integro, sed interdum subiter ascendente, margine undato, vix plicato; intus subnacreo, cicatrice modico, irregulari." (conchaphila)

"T. omnino planata, per totum superficiem affixa; extus, marginem versus laminata, purpureo radiata; intus, olivaceo-rufa, ligamento parvo, in medio undato, solidiore.

"Animal flavore cupreo tinctum.

"Var. laticaudata, Nutt. ms.: t. omnino purpurea, margine producto, undato; cardinem versus, denticulis conspicuis instructo." (lurida)

Holotype.-BM(NH); of lurida, syntypes Redpath Museum 125.

Type locality. - Mazatlan, Mexico, of lurida, Shoalwater, Willapa Harbor, Washington (Palmer, 1958, p. 67).

Supplementary description.- "Ordinarily it is a very small purple shell, frequenting other shells even when living, and often interfering with their growth. It is known by the very small triangular ligament area, with very fine denticles on each side. In addition to these, there are generally (in the attached valve) two lines of denticles situated in furrows running outside the area to the umbos. It begins life as a swollen regularly formed body, of the shape of Astarte compressa. A specimen from S.W. Mexico, in a dead Cypraea, retains this regularity and general form: it is smooth, white, and convex. The hinge of the attached valve, when extremely young, reminds one of Mesodesma; the ligament being internal between two raised processes followed by pits; the processes afterwards developing into the ligamental area. Sometimes the shell becomes rather thick, and, after continuing smooth and flat, suddenly rises, and waves (almost plicating) the outer margin." (Carpenter, 1857, p. 162)

"This is a rather small species of an irregular ellipsoidal or elongate shape, sculptured with crude, low, irregular plications, or almost smooth except for irregularities of growth." (Grant and Gale, 1931, p. 151)

"Valves thin, irregular in shape, usually circular or elongate, sometimes scalloped at the edges. Surface of both valves flat though may conform to contours of substrate." (Fitch, 1953, p. 38)

"The lower (left) valve, shallowly concave, may be attached by a small area beneath the umbo or attached by the entire surface. The upper (right) valve is flat and fits into slightly raised margins of the opposite valve. Several small denticles are present along the margin just anterior to the hinge area ***." (Hertlein, 1959, p. 6)

Comparison.- "Adult shells of $O$. angelica Rochebrune attain a much greater size and thickness than forms of $O$. lurida." (Hertlein and Grant, 1972, p. 217)

"The smaller size is the only apparent character that distinguishes elongate, weakly plicate left valves, and most right valves, of Ostrea vespertina sequens Arnold from moderately elongate shells of $O$. lurida." (Woodring, 1938, p. 44)

Geographic range._-Living: Alaska to Panama, especially common in Willapa Bay and Puget Sound, Washington; fossil: middle California to Baja California Norte.

Geologic range.-Pliocene to Holocene.

Occurrence in the Californias.-Pliocene: Almejas (Hertlein, 1933; Minch and others, 1976) and San Joaquin (Howard, 1935; Adegoke, 1969) Formations; Pliocene and Pleistocene: Fernando (Kennedy, 1975), Merced (Martin, 1916; Glen, 1959), and Saugus (Kew, 1924) Formations; Pleistocene: Anchor Silt (Rodda, 1957), Bay Point Formation (Kern and others, 1971), Carlotta Formation (Ogle, 1953), Medill Sand (Rodda, 1957), Palos Verdes and San Pedro Sands (Woodring and others, 1946), Timms Point Silt (Woodring and others, 1946), and unnamed strata in coastal southern California (Valentine, 1956), on San Nicolas Island (Vedder and Norris, 1963), and in Baja California Norte (Valentine, 1957).

Habitat.- "In the Pacific Northwest it is found in beds on the surface of mud flats and gravel bars near the mouths of rivers or streams. 
In other localities it is found in most sheltered inlets and bays along the entire coast, attached to the shells of previous generations of oysters or any firm surface that will hold it out of the mud. These beds may cover several acres and are usually exposed at low tide. Often when not in beds these oysters are found singly or in small clusters attached to rocks, cement pilings and particularly to metal buoys, floats, etc." (Fitch, 1953, p. 38)

Spawns at minimum temperatures of about 14 to $16{ }^{\circ} \mathrm{C}$ (Hopkins, 1936, p. 460). Intertidal to $50 \mathrm{~m}$ (Bernard, 1983, p. 23).

\section{Genus OSTREOLA?}

\section{Ostreola? venturana (Loel and Corey)}

Plate 31, figure 7; plate 33, figure 5

Ostrea venturana Loel and Corey, 1932, p. 193, pl. 15, fig. 2; pl. 18, figs. $1,2$.

Original description.- "Shell small, thin, ovate-pointed; lower valve moderately convex with no ornamentation other than fine incremental lamellae. In another specimen the interior of the lower valve is seen to be deep, muscle scar central and reniform, margins thin and finely serrate, and hinge area is triangular with narrow, deep ligament pit. Upper valve of another individual is convexo-concave or flat, with broad hinge area lower than in lower or right valve. Height, 12 $\mathrm{mm}$.; width, $6 \mathrm{~mm}$."

Holotype.-UCMP 31751.

Type locality.-UC A-321. Santa Barbara County, Calif. Vaqueros Formation, Oligocene and Miocene.

Comparison.- "Ostrea venturana ${ }^{* * *}$ resembles $O$. lurida ${ }^{* * *}$ in form, and may be ancestral to it, but is distinct in its constant smaller size and ovate-pinnate shape, lack of ornamentation, elongatereniform muscle scar, and serrate margins. The present discussed species is distinct in shape and in its lack of medial ridge from $O$. miguelensis Hertlein, the only other small Ostrea known from the Vaqueros horizon." (Loel and Corey, 1932, p. 193)

Geographic range.-Southern California.

Geologic range.-Oligocene and Miocene.

Occurrence in California.-Oligocene and Miocene: Vaqueros Formation (Loel and Corey, 1932; Weaver and Kleinpell, 1963).

\section{Ostreola? megodon (Hanley)}

Plate 32, figure 2, 5; plate 34, figures 1, 3, 6, 8

Ostrea megodon Hanley, 1846, p. 106. Jordan and Hertlein, 1926b, p. $427-428$, pl. 28 , fig. 1 . Durham, 1950, p. 59, pl. 5, fig. 3 .

Ostrea (Lopha) megodon Hanley. Keen, 1971, p. 84, fig. 173.

Ostrea (Agerostrea) megodon Hanley. Hertlein and Grant, 1972, p. 221-222, pl. 38, figs. 1, 5, 7. Smith, 1984, p. 206, pl. 4, figs. 1, 2. Agerostrea megodon (Hanley, 1846). Bernard, 1983, p. 23.

Ostrea cerrosensis Gabb, 1866, p. 35, pl. 11, fig. 61.

Ostrea megodon Hanley subsp. cerrosensis Gabb. Stewart, 1930, p. 130, pl. 14, fig. 1.

Not Ostrea (Alectryonia) megodon Hanley of Olsson, 1964, p. 39, pl. 1, figs. 1-1b [=O. messor Maury, 1925].

Original description.-_"Ost. Testâ falcatâ, glabrâ, solidâ, subaequivalvi, pallidè livido-purpurascente, margines versus plicatâ; plicis anticis 5 aut 6 , maximis, subangulatis; posticis minimis, angulatis, paucis sub-obsoletis; margine valde plicato, intusque magis minusve scabro; natibus incurvatis; superficie internâ albo-virescente, nunquam margaritaceâ; cicatrice satis magna, reniformi. Long. 5 poll." (megodon)

"Shell small, subequivalve, very oblique, strongly falcate, variable in form, upper edge entire, concave; lower margin very strongly undu- lated, each valve bearing four or five rounded, tongue-like processes, which alternate in the two valves; the margin, on each valve, between these processes, is very much thickened, and presents the squamose edges of successive layers of growth. Surface smooth, or marked only by rather indistinct lines of growth. Hinge long and very oblique, slightly curved. Muscular scars small, rounded subtriangular." (cerrosensis)

Holotype.-BM(NH). Lectotype of Ostrea cerrosensis ANSP 4494. Type locality.-Peru. Of O. cerrosensis, Isla Cedros, Baja California Norte, Almejas(?) Formation, Pliocene.

Supplementary description.- "Shell elongate arcuate, (length up to $100 \mathrm{~mm}$ ), the two valves nearly alike, ventral margin folded into three or four large, sharp but short plications, attached generally by a small area on the extreme umbone of the left valve. The dorsal side is concave or excavated, often finely corrugated on the margin. Surface smoothish or roughened by concentric growth incrementals." (Olsson, 1961, p. 173).

Hertlein and Grant (1972, p. 222) noted variation in the development of denticles on the shell margins and in the width and depth of fluting of Holocene specimens of $O$ ? megodon.

Comments.-The shells of the fossil specimens identified as $O$ ? megodon are half the size of Holocene specimens. Although this species bears a striking resemblance to the Cretaceous genus Agerostrea Vyalov, 1936 (Stenzel, 1971, p. N1158-N1160)), it differs from that presumedly lophine genus in having fewer marginal undulations; moreover these undulations are all limited to the antero-ventral margin and more rounded than those on Agerostrea. The anatomy of Ostreola? megodon is ostreine, not lophine. (Harold W. Harry, written commun., 1984)

Geographic range.-Living: Baja California Sur to Peru; fossil: southern California to Mexico.

Geologic range.-Miocene or Pliocene through Holocene.

Occurrence in the Californias.-Miocene or Pliocene: Imperial Formation (Stump, 1979); Pliocene: Almejas (Minch and others, 1976), Carmen (Durham, 1950), Gloria (Wilson and Rocha, 1955), Lomita Marl (Woodring and others, 1946), San Diego (Hertlein and Grant, 1972), San Marcos (Durham, 1950) Formations and unnamed Pliocene strata on Isla Tres Marias (Jordan and Hertlein, 1926a); Pleistocene: unnamed strata in southern California (Kanakoff and Emerson, 1959) and in Baja California Norte (Valentine, 1957).

Habitat.-From 5-20 m and $10-31^{\circ} \mathrm{C}$ (Bernard, 1983, p. 23).

\section{Subfamily OSTREINAE, incertae sedis "Ostrea" weaveri Dickerson Plate 29, figure 2}

Ostrea weaveri Dickerson, 1914, p. 127-128, pl. 9, fig. 3.

Original description. - "Shell medium in size, subequivalve, irregularly oval, contorted near the beaks, unattached. Surface marked by regular squamose lines of growth. Beak twisted and terminating at the anterior dorsal margin. The upper half is subglobose while the lower half is flat or slightly concave. These two portions are very deeply set off and the species is readily determined by this characteristic. In the lower valve, the bulging of the upper portion is less prominent. The growth lines are remarkably even for this genus."

Holotype.-UCMP 32624.

Type locality.-UC 781. Vicinity of Lower Lake, SEy/4, NEy/4, T. 12 N., R. 7 W., Lake County, Calif. Martinez Formation, Paleocene.

Comments. - The holotype is a single worn valve with only the exterior exposed. It is smooth and much inflated for its size on the dorsal half and flat to concave on the ventral half with prominent 
concentric shell lamellae. "Ostrea" weaveri in profile somewhat resembles "Quadriostrea" Vyalov (1936, p. 18), from the Cretaceous in Africa, which Stenzel (1971, p. N1169) considered an uncertain genus.

Geographic range.-Northern and middle California.

Geologic range.-Paleocene.

Occurrence in California.-Paleocene: Martinez Formation (Dickerson,1914).

\section{Subfamily CRASSOSTREINAE}

Though the three genera included here tend to be elongate dorsoventrally, they are often oval or even round. The right promyal passage is open but smaller than it is in Pycnodonteinae. They tend to live in shallower water than all the other oysters. Their shells are very erodable but they are thickened in several ways. Chalk and conchyolin deposits are common. Plication of left valve is rare (except in Saccostrea) and even more rare on right valve. Ostreine chomata are usually present, but absent throughout life in Crassostrea. Attachment absent throughout life in Crassostrea. Attachment area small to large; hyote spines absent, except in juveniles of Saccostrea, where they are variably present. Left valves sometimes enormously thickened, especially in Saccostrea and Striostrea. (Harold W. Harry, written commun., 1983)

\section{Genus ACUTOSTREA Vyalov, 1936}

Medium-sized (as much as $9 \mathrm{~cm}$. high); outline variable, mostly elongate-spatulate, straight, or more commonly falcate; subequivalve to inequivalve. Left valve beak commonly pointed, straight or variously curved, projecting beyond that of right valve; ligamental area acuminate, high triangular, length of resilifer commonly twice that of adjoining bourrelet; deep umbonal cavity overhung by hinge plate Left valve commissural shelf with rounded gutter in which pits of chomata are located. Left valve with many undulatory growth squamae and in some individuals few (about 6 ) wide low weak radial costae. Right valve lacks costae but has concentric growth squamae. (Stenzel, 1971)

Kiyotaka Chinzei (written commun., 1983) first suggested that I consider the genus Acutostrea for the included species. The genus previously was known only from the Upper Cretaceous.

Geographic range.-Europe and North America.

Geologic range.-Cretaceous to Eocene; Oligocene and Miocene(?) (table 8).

\section{Acutostrea simiensis (Zinsmeister)}

\section{Plate 34, figures 4, 5}

Ostrea simiensis Zinsmeister, 1983, p. 1286-1287, fig. 1E-G.

Original description.-- "Shell medium to small gryphaeiform; left valve narrow, but occasionally moderately broad; beaks mediumsized, blunt, prosogyral to nearly orthogyral; somewhat enrolled with small attachment area; left valve smooth with infrequent low concentric undulations; poorly developed radial sulcus; right valve flat to slightly concave with faint squamae."

Holotype.-UCR 6899/101.

Type locality._UCR 6899. Ventura County, Calif., Simi Conglomerate, Paleocene.

Supplementary description. - "This species is easily recognized by its narrow, elongated outline and small to medium size."(Zinsmeister. 1983)

Comparison.- "O. simiensis n. sp. is similar to O. halevi Hertlein from the Eocene, but is not quite as narrow and the beak is more prosogyral. The close similarity of the two species suggest that $O$. simiensis n. sp. may be ancestral to $O$. haleyi. The only other oyster $(O$ weaveri Dickerson) occurring in the upper Paleocene of the Simi Hills can easily be distinguished by its larger size and coarse, evenly spaced squamae." (Zinsmeister, 1983)

Geographic range.--Southern California.

Geologic range.-Paleocene.

Occurrence in California.-Paleocene: Simi Conglomerate (Zinsmeister, 1983).

\section{Acutostrea idriaensis fettkei (Weaver)}

Plate 30, figure 5; plate 32, figures 4, 6; plate 33, figures 1-3, 8

Ostrea fettkei Weaver, 1912, p. 30, pl. 4, figs. 37, 39.

Ostrea idriaensis (?var.) fettkei Weaver. Vokes, 1935, p. 291.

Ostrea idriaensis Gabb var. fettkei Weaver. Vokes, 1939, p. 54-55, pl. 2, figs. 11, 13.

Ostrea crandalli M. A. Hanna, 1927, p. 275, pl. 29, figs. 1, 2.

Ostrea buwaldana Dickerson, 1914, p. 127, pl. 9, fig. 4

Original description. - "Shell small, thin, somewhat curved, right valve nearly flat, left valve convex; hinge deflected to the left and median groove very well marked; internal margins in both old and young forms are pitted; shell inequivalve and slightly inequilateral; left valve ornamented by a marked median ridge extending from beak to basal margin; anterior to this ridge are two radiating ribs becoming obsolete toward the beaks; posterior surface with six radiating ribs extending to the beak; these are crossed by a large number of concentric ribs and lines of growth." (fettkei)

"Shell of medium size or less, roughly trigonal to pyriform, as figured; beak acute, not curved; thin, with six large well rounded unequal sized ribs which are separated by deep round-bottomed interspaces; crossed by prominent growth lines which become rough laminae on the ribs; valve slightly distorted below the beak; inner margin crenulate, corresponding to the ribs and interspaces of the outer surface; hinge margin trigonal, slightly rounded internally, central depression narrow, relatively shallow, bordered on either side by an area which appears rough due to the presence of three rounded toothlike elevations; submargins not denticulate; interior smooth; adductor scar marginal, more sub-circular than the figure would indicate. Dimensions: Altitude $30 \mathrm{~mm}$., length $43 \mathrm{~mm}$., diameter $15 \mathrm{~mm}$." (crandalli)

"Shell, medium, with thick shell substance, only slightly oblique, elliptical; upper valve flat; lower valve deep, convex and marked by rough, squamose growth lines and about six strong radiating ribs. Muscular scar is reniform, nearly central. Internal margins of some specimens distinctly pitted on both sides of beaks in casts of this species. Occasionally small tooth-like projections are seen on the shell itself on both sides of the beaks." (buwaldana)

Holotype.-CAS 479; of crandalli UCMP 31072; of buwaldana UCMP11719.

Type locality.-One and one-half miles east of Vader on north bank of Cowlitz River in sec. 27, T. 11 N., R. 2 W., Cowlitz County, Washington. Cowlitz Formation, Eocene; of crandalli UC 3981 San Diego County, Calif., Delmar Formation, Eocene; of buwaldana UC 790, Lake County, Calif., Martinez Formation, Paleocene.

Comparison.- "Ostrea fettkei Weaver represents a variety of Ostrea idriaensis bearing definite ribs which are of primary strength and not interrupted by the growth-lines. The specimens from the New Idria region are all larger than those from the Washington localities." (Vokes, 1939, p. 54-55)

Comments. - The holotype of Ostrea buwaldana is a badly worn specimen and is assumed to be a left valve. Only the internal shell layers are preserved and they show fairly large, radial ribs. Vokes $(1935$, p. 292 ), in his description of idriaensis, said that there is a tendency toward the development of a radial type of ribbing but that 
this is always a secondary feature superimposed upon and interrupted by the lamellae.

Geographic range.-Washington to southern California; Kamchatka(?) (Pleshakov, 1939).

Geologic range.-Paleocene and Eocene.

Occurrence in California.-Paleocene: Martinez Formation (Dickerson, 1914); Eocene: Avenal Sandstone (Vokes, 1939), Delmar (M. A. Hanna, 1927) and Domengine (Vokes, 1939; Weaver, 1949) Formations, and La Jolla Group (Vokes, 1939).

\section{Acutostrea idriaensis idriaensis (Gabb)}

Plate 13, figures 2, 3; plate 14, figure 6; plate 16, figure 3; plate 29, figures 3-5

Ostrea idriaensis Gabb, 1869, p. 203, pl. 33, figs. 103b, c, d; pl. 34, figs. 103, 103a. Arnold, 1909, p. 106, pl. 2, figs. 4, 5. M. A. Hanna, 1927, p. 276 , pl. 30 , figs. 1,2 ; pl. 31, figs. 3,4 . Stewart, 1930, p. 126, pl. 8 , fig. 3; pl. 17, fig. 1. Vokes, 1935 , p. 291-295, pls. 22-24. Turner, 1938 , p. 46, pl. 6, fig. 9. Vokes, 1939, p. 54. Givens, 1974, p. 44. Ostrea columbiana Weaver and Palmer, 1922, p. 13, pl. 8, figs. 15, 16. Ostrea oregonensis Packard, 1923, p. 4-6, pls. 1-4.

Ostrea haleyi Hertlein, 1933, p. 277, pl. 18, figs. 5, 6.

?Odontogryphaea? haleyi (Hertlein). Givens, 1974, p. 45, pl. 1, figs. 11-13.

Original description.-_"Shell moderately large, oblique, often curved, heavy; lower valve usually deep, more oblique than the upper; hinge straight or deflected to the left, median groove pretty strongly marked; internal margins in the young shell, finely crenulated or pitted towards the beak, this character disappearing to a great extent in the adult. Surface of both valves roughly and very irregularly squamose. Muscular scar reniform to semicircular, and placed distinctly to one side of the middle." (idriaensis)

"Shell large and elongate in outline; right valve very convex and irregular; left valve flat or concave with the anterior end straight dorsally, swinging into the ventral margin with a broad curve which continues ventrally to the posterior ventral end; posterior end with a more or less deep concave area at about one-third of the distance from the dorsal line; shell very thick; surface of the left valve rough and irregular with overlapping laminae; surface of the right valve smoother, the growth lines more regular than those of the left valve; left valve with a glossy, corneous outer layer over which are fine yet conspicuous radiating lines; beaks deflected posteriorly; anterior and posterior margins internally or laterally with coarse transverse grooves." (columbiana)

"Shell large, very thick and irregular; subcircular to subovate in outline; left valve very convex, tumid; right valve opercular-form. Anterior dorsal margin of left valve of type and cotype very regularly rounded, for nearly 180 degrees from the beak; base sloping upwards to the slightly attenuated but evenly rounded posterior end. Umbone of type very prominent, strongly curved inward and backward and terminating in a sharply pointed, slightly twisted beak. In both specimens the beaks lie well within the margin of the shell. The beak of the cotype is deformed by a large, linear scar of attachment which shows the external mold of a gastropod. An indistinct umbonal ridge extends in a curve, anteriorly, for about half the distance to the anterior extremity. The outline of the flat upper valve of the type is nearly elliptical, much thinner, than the lower one and only slightly convex. Umbone depressed; beak small, twisted slightly posteriorly and situated well within, but not far from the margin of the shell. Surface of left valve marked by heavy concentric imbricating growth lamellae which are irregularly nodose, tending to be radially arranged on the umbone. The growth lamellae of the right valve are thin, ridge-like and lack the nodose character of the left except at the very apex where faint radiating costae may be seen.
"Interior of left valve with a broad shallow irregular ligamental groove, slightly depressed near and parallel to the margin of the shell; lateral margins of hinge and valve pitted or crenulated, the crenulations extending on either side nearly to the base. Adductor scar impressed, situated posterior to the center." (oregonensis)

"Shell elongate, rounded umbos, broader toward the base; beak curved inward and backward; a shallow groove extends from near the beaks to the ventral margin of the shell where it is more pronounced; a well-defined ligament pit is present beneath the beak. Altitude 45.5 mm.; approximate longitude (shell not complete) $32.5 \mathrm{~mm}$." (haleyi)

Holotype.-Lectotype of idriaensis MCZ 15048 (Stewart, 1930); of columbiana, missing and presumed lost; of oregonensis UO 20; of haleyi CAS 5526.

Type locality. - About $3 \mathrm{~km}$ east of Hacienda at the New Idria [Priest Valley Quad., N1/2 sec. 15, T. 17 S., R. 12 E., San Benito County, Calif.], Domengine Formation, Eocene. Of columbiana UW 160A, Cowlitz County, Wash. Cowlitz Formation, Eocene; of oregonensis UO 130 , Douglas County, Oregon, Umpqua Formation, Eocene; of haleyi Cañada del Pozo, Santa Cruz Island, Santa Barbara County, Calif. Cañada(?) Formation, Eocene.

Supplementary description.- "The characters which appear to be diagnostic for Ostrea idriaensis Gabb are:

1. Valves discrepant in size; the lower much larger than the upper.

2. Shape variable; umbos generally straight or twisted to the left,but may be slightly twisted to the right.

3 . Valves elongate and broader near the base.

4. Lower valve with rugose, coarse, concentric lamellae of growth, a superimposed radial ribbing commonly present; upper valve with finer lamellae of growth, ribbing not present.

5. Lines on the sides of the upper valves near the umbos, reflecting the denticulations present on the lateral margins of the body area of the shell.

6. Ligamental area of the lower valve consisting of a well-marked median groove with two prominent ridges, one on each side, which are bounded by small, linear, lateral grooves at the edges of the area.

7. Ligamental area of the upper valve with a median groove, and two lateral grooves complementary to the ridges of the ligamental area of the lower valve.

8. Ligamental area commonly twisted to the left, but may be straight or slightly twisted to the right.

9. Denticulations present on the lateral margins of the body area of the upper valve near the ligamental region, fitting into pits on the lateral margins of the body area of the lower valve.

10. Left margin of the lower valve commonly with an impressed area into which a corresponding protuberance on the upper valve is fitted.

11. Muscle scar reniform to subcircular; situated approximately onesixth of the distance across the body area from the left side." (Vokes, 1935, p. 295)

Adult specimens show a great variation in size. Vokes (1935, p. 292) noted that adult left valves range from 65 to $92 \mathrm{~mm}$ in height, 50 to $61 \mathrm{~mm}$ in length, and 26 to $34 \mathrm{~mm}$ in thickness; adult right valves range from 61 to $64 \mathrm{~mm}$ in height, $50-53 \mathrm{~mm}$ in length, and 14 to $21 \mathrm{~mm}$ in thickness.

Comparison.--In O. idriaensis radial ribbing may develop but it is a secondary feature superimposed upon and interrupted by lamellae, whereas in $O$. idriaensis fettkei some of the radial ribs become a primary sculptural feature and are little interrupted by growth lamellae. (Vokes, 1935, p. 292-293)

The two linear lateral grooves in the ligamental area of $O$. idriaensis are never as strongly developed as they are on $O$. stewarti $\mathrm{M}$. A. Hanna, and the muscle scar on the left side of the body area is never so circular as on $O$. stewarti. (Vokes, 1935, p. 293, 294)

Geographic range.-Washington to southern California. 
Geologic range.-Eocene.

Occurrence in California.-Eocene: Avenal Formation (Vokes, 1939), Cañada Formation (Doerner, 1969), Coldwater Sandstone (Weaver and Kleinpell, 1963), Delmar (M. A. Hanna, 1927), Domengine (Vokes, 1939; Givens, 1974), and Juncal (Givens, 1974) Formations, La Jolla Group (M. A. Hanna, 1927), Matilija Sandstone (Givens, 1974), Sacate (Dibblee, 1950), and Tejon (Givens, 1974) Formations.

\section{Genus ACUTOSTREA?}

\section{Acutostrea? miguelensis (Hertlein)}

Plate 33, figures 4, 6, 7, 9

Ostrea miguelensis Hertlein, 1928, p. 146, pl. 23, figs. 3-6. Loel and Corey, 1932, p. 191, pl. 10, figs. 2a, 2b, 3a, 3b.

Original description.- "Shell small; obliquely subovate, beaks pointed; shell fairly thick. Lower valve convex, a slight groove runs from beak to umbo, two or three irregular projections of shell material are irregularly scattered on valve, ornamentation consists of fine lamellar edges of shell. Upper valve gently concave with a small raised median ridge which runs from the beak for one third the length of shell, otherwise ornamented only by the incremental shell lamellae. Height from beak to base, $21.5 \mathrm{~mm}$.; greatest anterior-dorsal width, 21 mm.; convexity of valves, $9.1 \mathrm{~mm}$."

Holotype.-CAS 4121.

Type locality.-CAS 1163. San Miguel Island, Calif. Vaqueros Formation, Oligocene and Miocene.

Comparison.- "Ostrea miguelensis is distinct through its possession of a narrow medial plication effecting [sic] both valves." (Loel and Corey, 1932, p. 191)

"This small oyster*** in many of its features seems to resemble $O$. idriaensis Gabb, from the Upper Eocene but it is much smaller and commonly possesses a median ridge on the upper valve. $O$. miguelensis resembles the early part of $O$. bourgeoisii Remond, from the Upper Miocene of California but is more ovate and does not attain a large size; many of the specimens are not ornamented except for the incremental lines of growth. In some specimens the beaks turn anteriorly, in others posteriorly; apparently the direction depends upon the position assumed at the time of attachment. The raised median ridge on the upper valve appears to be an unusual feature in this interesting little shell." (Hertlein, 1928, p. 146)

Comments.-Although I am reasonably satisfied with the generic placement of miguelensis, I have queried the generic assignment because neither of the small double-valved syntypes has the interior of the valves exposed.

Geographic range.-Southern California.

Geologic range.-Oligocene and Miocene.

Occurrence in California.-Oligocene and Miocene: Vaqueros Formation (Hertlein, 1928; Loel and Corey, 1932).

\section{Genus SACCOSTREA Dollfus and Dautzenberg, 1920}

Small to medium-sized, outline variable. Left valve with large attachment area; radial ridges on upturned part. Umbonal cavity usually very deep. Right valve flat, free of folds, but has many scaly growth squamae. Both valves usually have strong chomata which commonly encircle entire valve. Conchyolin deposits abundant. Exterior usually very eroded; contour pattern usually present on right valve.

Differs from Crassostrea in its deeper umbonal cavity, strong chomata, and tendency to conical rudistiform or cornucopialike shapes.
Geographic range.-Nearly circumglobal in the tropics; but absent among living oysters in the western Atlantic.

Geologic range.-Miocene to Holocene (table 9).

Habitat.-Chiefly intertidal, mostly on noncalcareous rocks in surf zone. Occasionally on mangrove in high salinity zone.

\section{Saccostrea palmula (Carpenter) Plate 18, figures 1-6}

Ostrea ?? conchaphila, var. palmula Carpenter, 1857, p. 163-164, 550. Ostrea palmula Carpenter. Keen, 1971, p. 84, fig. 174.

Original description.-O $O$.? conchaphila $\mathrm{t}$. satis magna, margine subito ascendente, valva inferiore superante, undulato, limbo purpureo scu olivaceo irregulariter tessellato; linea pustularum valva superiore, in parte nacrea a margine remota, circumeunte, in puncta convenientia valva inferiore aptante; pagina interna subnacrea, aurantio seu purpureo tincta; rarissine spinis ramosis paucis, tabulis ad marginum exteriorem arborescentibus.

Holotype.-BM(NH).

Type locality.-Mazatlan.

Supplementary description. - "Remarkable for the palmated foliations in the outer margin, which has a distinct limb mottled with purple and olive; and for the row of denticles within this limb and within the nacreous border, fitting into corresponding depressions in the other valve." (Carpenter, 1857)

"One of the most variable of the Panamic province oysters, this may be recognized by the flat or even concave upper valve that fits down into the plicate margins of the cup-shaped lower valve ${ }^{* * *}$." (Keen, 1971, p. 84)

Comparison.- "Modern shells *** of $O$. palmula Carpenter, resemble ovate or ovate-falcate specimens of the coastal vespertina in size, but they have an exceptionally long strongly fluted area on the inner margin." (Woodring, 1938, p. 44-45)

According to Woodring (in Woodring and Bramlette, 1950, p. 85) $S$. palmula has more numerous plications and is considerably smaller than Dendostrea vespertina.

Comments. - Saccostrea palmula has an exceptionally large attachment area, obliterating all but the commissure on some left valves, and the posterior half of the left valve rises vertically from the attachment area. The unattached valve fits snugly down into the attached valve.

Geographic range.-Living: eastern Pacific tropics and Galapagos Islands; fossil: southern California to Baja California Sur.

Geologic range.-Miocene or Pliocene to Holocene.

Occurrence in the Californias. - Miocene or Pliocene: Imperial Formation (Stump, 1979); Pliocene: Pico (Waterfall, 1929) and Salada (Beale, 1948) Formations.

\section{Genus STRIOSTREA Vyalov, 1936}

The hinge line of Striostrea is usually long relative to that of other oysters; the left beak often very large. The shell interior is subnacreous and the right valve peculiarly brittle, with flaky splinters left at the fractures. Juveniles have prominent ostreine chomata which are usually reduced or even absent in larger specimens. The numerous fragile, appressed lamellae of the right valve have peculiar fine radial striae on them, but this is best seen on small shells, as the valves become much eroded as they grow. The shells generally grow to ponderous size (as much as $20 \mathrm{~cm}$ high) and usually attach by most of the left valve to firm rocks. The left valve often becomes very thick, by continuous secretion of the foliar layer, and the specimens may be raised thus on pedicels, as high as the maximum dimensions of the shell in profile. Much brown conchyolin is produced in the process, but 
chalk formation is not as common as in Crassostrea. (Harold W. Harry, written commun., 1983)

Differs from Crassostrea by having chomata, a nacreous and iridescent interior, a very foliaceous shell structure, and a rudistiform growth pattern.

Geographic range.-North America, east and south Africa, Madagascar, Central America, west coast of Baja California. The eastern Pacific Tertiary species are all questionably assigned to Striostrea.

Geologic range.-Eocene to Holocene (table 9).

Habitat.-In shallow subtidal waters where there is strong surf and constant oceanic salinity. (Harold W. Harry, written commun., 1983)

\section{Genus STRIOSTREA?}

\section{Striostrea? tayloriana (Gabb)}

Plate 29, figures 7, 8

Ostrea tayloriana Gabb, 1869, p. 34, pl. 12, figs. 60, 60a. Grant and Gale, 1931, p. 153. Weaver and Kleinpell, 1963, p. 197, pl. 29, figs. 6, 8.

Not Ostrea tayloriana Gabb. Jordan and Hertlein, 1926b, p. 428, pl. 33, fig. 3 [ = Ostrea erici Hertlein, 1929].

Original description.- "Shell large, thick, irregularly subtriangular, resembling somewhat some of the more massive forms of $O$. virginica; not attached. Surface covered by heavy, irregular, subsquamose plates, showing more or less of a faint undulation on their edges. Interior unknown. Hinge broad and short(?)."

Holotype.-UCMP 12005.

Type locality.-San Marcos Pass, near Santa Barbara [N12/2 sec. 21, T. 5 N., R. 28 W., Santa Ynez Quadrangle]. Santa Barbara County, Calif. Gaviota(?) Formation, Eocene and Oligocene.

Comments.-The supposed relationship of S.? tayloriana to Crassostrea was first suggested by Gabb, when he commented on its similarity to Crassostrea virginica, and later by Dall (1909, p. 111), when he erroneously synonymized it with Crassostrea titan titan. The holotype is a double-valved specimen with the valves together and closed, thus making the hinge inaccessible. Weaver and Kleinpell (1963, pl. 29, fig. 8) illustrated a left valve of tayloriana, assumed to be correctly identified, and their specimen shows the interior of the shell.
Geographic range.-Southern California.

Geologic range.-Eocene and Oligocene.

Occurrence in California.-Eocene: Coldwater Sandstone (Bailey, 1952); Eocene and Oligocene: Gaviota Formation (Dibblee, 1950); Oligocene: Alegria Formation (Dibblee, 1950; Weaver and Kleinpell, 1963).

\section{Striostrea? appressa (Gabb)}

Plate 12, figure 3; plate 16, figure 5

Ostrea appressa Gabb, 1869, p. 203-204, pl. 34, figs. 104, 104a. Stewart, 1930, p. 127-128, pl.13, fig. 1.

Original description.- - Shell thin, flat, more or less equilateral, valves nearly equal, usually about two-fifths longer than wide. Surface covered by numerous, thin, squamose plates. Hinge flat, large; margins simple, sometimes subsquamose. Muscular scar small, oblique."

Syntype.-MCZ 15013 [The best of four specimens labelled in Gabb's handwriting, according to Stewart, 1930, p. 127]. Missing and presumed lost.

Type locality.-On one of the branches of Eel River, at the mouth of Salt Creek, southwest of Round Valley, Mendocino County, Calif. Tejon Formation of Gabb (1869) or Temblor Formation of Samuel G. Clark (1940).

Supplementary description.- "The species is remarkable for its thin, flat shell, often distorted, and for its broad, flat hinge." (Gabb, 1869 , p. 204)

"The free valve is convex externally, near the hinge, and concave in the central part *** One specimen retains radial ribs on the external central portion of the valve." (Stewart, 1930, p. 128)

Geographic range.-Northern California.

Geologic range.-Eocene(?) or Oligocene and Miocene.

Gabb (1869, p. 203) wrote, "I found this shell forming a stratum several feet thick, adjoining a bed of coal, and in associated strata were familiar species characteristic of the Tejon Group.

"The locality is on one of the branches of Eel River, at the mouth of Salt Creek, southwest of Round Valley ***."

Samuel G. Clark (1940, p. 135) placed Gabb's type locality (Middle Fork of the Eel River at the mouth of Salt Creek, NE $1 / 4$ sec. 11, T. 21 N., R. $13 \mathrm{~W}$.) in the Temblor Formation. He said that in the shale above the

TABLE 9.-Geologic and geographic distribution of the genera Saccostrea and Striostrea? in the eastern Pacific region

$[\mathrm{H}=$ Holocene; $\mathrm{Pl}=$ Pliocene; $\mathrm{M}=$ Miocene; $\mathrm{O}=$ Oligocene; $\mathrm{E}=$ Eocene $]$

\begin{tabular}{|c|c|c|c|c|c|c|}
\hline \multirow[t]{2}{*}{ Species } & \multicolumn{3}{|c|}{ California } & \multicolumn{2}{|c|}{ Baja California } & \multirow{2}{*}{$\begin{array}{l}\text { Central } \\
\text { or Soutl } \\
\text { America }\end{array}$} \\
\hline & Northern & Middle & Southern & Norte & Sur & \\
\hline 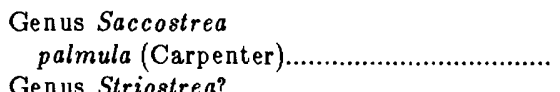 & $\cdots \cdot$ & $\cdots \cdot$ & $\mathrm{M}$ ? and $\mathrm{Pl}$ & $\mathrm{H}$ & $\mathrm{Pl}$ to $\mathrm{H}$ & $\mathbf{H}$ \\
\hline 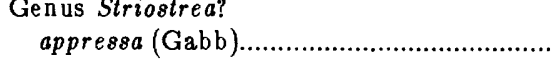 & $E$ ?, $O$, and $M$ & $\cdots \cdot$ & $\cdots .$. & $\cdots \cdot$ & $\cdots \cdot$ & $\cdots \cdot$ \\
\hline 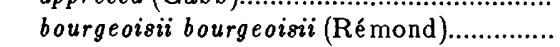 & n.... & $\mathbf{M}$ & $\mathbf{M}$ & $\cdots \cdot$ & $\cdots \cdot$ & $\cdots \cdot$ \\
\hline bourgeoisii perrini (Hall and Ambrose)..... & $\cdots \cdot$ & M & & $\cdots \cdot$ & $\cdots \cdot$ & $\cdots \cdot$ \\
\hline freudenbergi (Hertlein and Jordan)............. & $\cdots \cdot$ & $\cdots \cdot$ & $\mathrm{O}$ and $\mathrm{M}$ & M & $\mathbf{M}$ & $\cdots \cdot$ \\
\hline subtitan (Loel and Corey).............................. & $\cdots \cdot$ & $\cdots \cdot$ & $O$ and $M$ & $\cdots \cdot$ & $\cdots \cdot$ & $\cdots \cdot$ \\
\hline 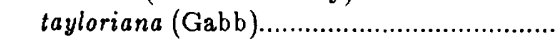 & … & ..... & $\mathrm{E}$ and $\mathrm{O}$ & ..... & ..... & $\cdots$ \\
\hline
\end{tabular}


coal seam were some oysters and gastropods that F. E. Turner said could be either Miocene or Eocene and that the nearest strata equivalent to Gabb's Tejon was $2.2 \mathrm{~km}$ up the river.

Because Gabb (1869, p. 203) said that he found appressa adjoining a bed of coal, it seems reasonably certain that the type locality is indeed in the Temblor Formation as mapped by S. G. Clark ( 1940 ; locality 56 ). A Desmostylus tooth was collected, presumably at this same locality, and is in the collections of the California Academy of Sciences (VanderHoof, 1937). The oldest known geologic record for Desmostylus is late Oligocene, and the genus is common in the Temblor Formation. It seems more likely that $C$.? appressa was collected from the Temblor Formation than from Gabb's Tejon, yet it is puzzling that Gabb (1869, p. 203) said he found "familiar species characteristic of the Tejon Group" in associated strata with $C$.? appressa.

Occurrence in California.-Oligocene and Miocene: Temblor(?) Formation (Clark, 1940).

\section{Striostrea? freudenbergi (Hertlein and Jordan)}

\section{Plate 26, figure 3; plate 27, figure 3}

Ostrea freudenbergi Hertlein and Jordan, 1927, p. 622, pl. 17, fig. 9; pl. 18, fig. 4. Loel and Corey, 1932, p. 190-191, pl. 14, figs. 1a, 1b; pl. 15, figs. 1a, 1 b.

?Ostrea freudenbergi Hertlein and Jordan. Adegoke, 1969, p. 108, pl. 4, fig. 7 ; pl. 5 , fig. 7 .

Original description.- - "Shell elongate, thickness medium, right valve moderately arched, narrow at beak but widening ventrally, made up of flattish layers of shell material which is ornamented by faint, rather small radial plications. Interior of valve under beak possesses a ligament pit which is rather prominent, long, fairly broad and moderately impressed; concavity of shell moderately deep, just ventral to ligament pit but becoming flatter toward the ventral margin; ventral muscle scar fairly large, impressed and located on the anterior side of the shell about a third of the length of shell from the ventral margin. Height $88.5 \mathrm{~mm}$.; length $61.1 \mathrm{~mm}$.; greatest diameter $21.1 \mathrm{~mm}$."

Holotype.-CAS/SU 5138.

Type locality.-CAS/SU 59. "Turritella bed above San Gregorio Lagoon, 120 miles [190 km] north of Magdalena Bay *** on the trail from Arroyo Mesquital to La Purisima." Baja California Sur, Isidro(?) Formation, Miocene.

Comparison.- "Ostrea freudenbergi can be distinguished from $O$. chilensis Philippi and other west coast Ostreas by its only moderately high right valve, elongate shape, faint radial ornamentation, differently shaped ligament pit and long, narrow beaks." (Hertlein and Jordan, 1927, p. 622)

Comments.—One method suggested by Stenzel (1971, p. N995) for distinguishing the right from the left valve on oysters is to draw the mid-axis on a valve. The center of the adductor muscle then falls to the left side on the inner face of the left valve and to the right side on the right valve. If this is done on the holotype of $S$.? freudenbergi, it is seen to be a left valve, although it was described as a right valve (Hertlein and Jordan, 1927, p. 622).

The left valve holotype of $S$.? freudenbergi is small, relatively thick with faint traces of radial ribs. It is narrow for about half the height of the shell and then widens. The muscle impression is deep and subquadrate. The ligamental area is moderately narrow and the resilifer shallow. The faint radial ribs suggest Striostrea.

Geographic range.-Southern California to Baja California Sur.

Geologic range.-Oligocene and Miocene.

Occurrence in the Californias.--Oligocene and Miocene: Vaqueros Formation (Loel and Corey, 1932; Vedder, 1973); Miocene: Isidro(?) Formation (Hertlein and Jordan, 1927), Saltos Shale Member, Monterey Shale (Vedder, 1973), and Tortugas Formation (Minch and others, 1976).

\section{Striostrea? subtitan (Loel and Corey)}

Plate 22, figures 3-5

Ostrea titan Conrad. Arnold, 1907a, pl. 40, fig. 2. Not Ostrea titan Conrad, 1853.

Ostrea new species near titan Conrad. Arnold, 1907b, p. 32.

Ostrea titan (Conrad) subtitan Loel and Corey, 1932, p. 192, pl. 18, fig. 3.

Original description.- "There occurs in the Vaqueros horizon an Ostrea species which is identical in all characters with O. titan Conrad except in its constant comparatively greater length in proportion to height ('wider' valves) and smaller size. Arnold (loc. cit.) noted this from the Vaqueros of the western Santa Ynez Mountains, where it is associated with a typical Vaqueros assemblage. An Ostrea of very similar form occurs in the Oligocene in this same region. This form is probably ancestral to $O$. titan Conrad (1853) of Middle and Upper Miocene. The specimen figured is from Univ. Calif. loc. A326, San Antonio Creek, Ventura County, found associated with Pecten magnolia, Rapana vaquerosensis, and others characteristic of Vaqueros, Lower Miocene."

Holotype.-UCMP 31750.

Type locality.-UC A-326. Ventura County, Calif. Vaqueros Formation, Oligocene and Miocene.

Comments.-The holotype is a double-valved specimen with the valves separated. The specimen, poorly preserved, has few distinguishing features except that it has a rounder outline than C. titan and is smaller. The adductor muscle impression is somewhat reniform, suggesting Striostrea.

Geographic range.-Southern California.

Geologic range.-Oligocene and Miocene.

Occurrence in California.-Oligocene and Miocene: Vaqueros Formation (Loel and Corey, 1932); Miocene: Beechers Bay Member (Weaver and Doerner, 1969) and Saltos Shale Member (Vedder, 1973) of the Monterey Formation.

\section{Striostrea? bourgeoisii bourgeoisii (Rémond)}

\section{Plate 25, figure 1; plate 26, figure 5}

Ostrea bourgeoisii Rémond, 1863, p. 13. Gabb, 1866, p. 33, pl.11, figs. 57, 57a. Clark, 1915, p. 447-448, pl. 43. Eaton, Grant, and Allen, 1941, p. 240 , pl. 3 , fig. 1. Hertlein, 1951a, p. 188, fig. 1 , no. 1.

Original description.- - "Shell suboval, higher than long, strongly contracted near the cardinal area, sub-rounded on the ventral margin; inferior valve comparatively thin, convex, irregular exteriorly, with remote, somewhat rugose plaits of growth. Ligament fossa long, profound, minutely wrinkled and finely striated, oblique and turned downwards; muscular impression very large, oblique, and sub-central, somewhat prominent."

Holotype.-Location unknown. Rémond (1863, p. 13) said that he was describing "two lower valves, from the collections of Mr. l'Abbe Bourgeois (Pont-Levoy, France) and Mr. Bioche (San Francisco)".

Type locality.-Vicinity Kirker's Pass [N1/2, sec. 9, T. 1 N., R. 1 W.], Contra Costa County, Calif. Briones Sandstone, Miocene.

Supplementary description.-Takeo Suzuki (written commun., 1982) says that Striostrea? bourgeoisii bourgeoisii is characterized by a thick left valve, which is arched and has a long, narrow, slightly curved resilifer trough, and that the right valve is much flatter than the left and has a narrow, long resilifer.

" $O$. bourgeoisii Rémond somewhat resembles $O$. titan Conrad in its size and thickness, though it is never as large. The maximum length as measured from the beak through the muscle impression is about eight to ten inches, with a maximum width at right angles to this of about five inches. Both valves vary considerably in thickness; sometimes the shell of the ventral valve has a thickness of from two to three inches. 
The ventral valve is usually only slightly more convex than the upper valve but is usually somewhat thicker. The fine radiating ridges on the surface, described by Remond, are not constant, appearing on only a few specimens that the writer has seen.

" $O$. bourgeoisii Rémond differs from $O$. titan Conrad in that the ligamental pit is narrower and the ligamental callus is heavier; on Ostrea titan Conrad the ligamental pit extends nearly across the anterior end of the shell; the muscle impression on $O$. bourgeoisii Remond is much smaller and is nearer the posterior end of the shell than on O. titan Conrad; on the latter species the muscle impression is sometimes nearly half the width of the shell; the ventral valve of $O$. titan Conrad is usually more strongly convex. A large number of specimens of both species were examined and these differences were found to be constant." (Clark, 1915, p. 448)

One of the oldest oysters, in terms of its life span, as seen by Stenzel (1971, p. N1016), is a specimen of $S$.? bourgeoisii bourgeoisii from the Temblor Formation (CAS 33269). The ligamental area is $2 \mathrm{~cm}$ long and $13 \mathrm{~cm}$ high; the apex is missing but the remainder has 43 annual layers.

Comparison.- "Fragment of lower (left) valve, showing the characteristic narrow, commonly curved ligamental pit and uneven, wavy growth lamellae which differentiate this species from $O$. titan and $O$. titan var. prior. Average adult is about 7 inches long. No specimen observed has much more than half the length of an adult $O$. titan; has commonly the length but only about half the mass of $O$. titan var. prior. Differs from $O$. ligminuta of somewhat similar average length in its much thinner valves, relatively large body cavity, longitudinally curved shell, and uneven growth lamellae. From $O$. cierboensis in being highly elongate instead of sub-rounded in outline, in having a narrow, round, and elongate instead of a wide, flattish, and extremely short ligamental pit, and in lacking the broad, somewhat even radial plications of the latter." (Grant and Eaton in Eaton, Grant, and Allen, 1941.)

Comments.-The fine riblets on some specimens and patches of nacreous shell suggest assignment to Striostrea.

Geographic range.--Middle and southern California.

Geologic range.-Miocene.

Occurrence in California.-Miocene: Briones Formation (Trask, 1922), Branch Canyon Sandstone (Hill, Carlson, and Dibblee, 1958), Cierbo Sandstone (Huey, 1948), Neroly (Hall, 1960), San Pablo Formation (Clark, 1915), and Santa Margarita (Addicott and Vedder, 1963), and Topanga (Kew, 1924) Formations.

\section{Striostrea? bourgeoisii perrini (Hall and Ambrose)}

Plate 26, figure 4; plate 27, figure 5

Ostrea titan Conrad var. perrini Hall and Ambrose, 1916, p. 80-81. Wiedey, 1929a, p. 22, pl. 3, fig. 1.

Original description.- "Lower valve. Shell irregularly elliptical, contracted at beak; beak curved toward right when viewed from exterior; right valve very ventricose; extremely laminated, giving rough plaited surface; left valve almost flat, laminated; muscle-scars distinct; hinge long, narrowing at beak, viewed from interior curves to left; cavity of hinge deep, coarsely wrinkled, with wrinkles running up onto either side of hinge; interior of hinge ends abruptly, cutting at right angles toward interior of shell, although not characteristic of all forms."

Holotype.-CAS/SU 502.

Type locality.-Pleasanton Quadrangle, Alameda County, Calif. Briones Sandstone of San Pablo Group, Miocene.

Comparison.- "This species greatly resembles $O$. titan Conrad, the main difference between the two being in the hinge. This variety has a long curved pointed hinge, while the $O$. titan has a much shorter hinge, about as wide as long. Also the summit of this variety does not rise above the beak of the opposite valve. All forms do not have as curved a hinge as this one figured. It is generally elongate, and seldom, if ever, has the subcircular shape the O. titan often has." (Hall and Ambrose, 1916, p. 81)

Comments. - The characters given by Hall and Ambrose (1916,p. 81) to distinguish perrini from titan are basically the same as those used to distinguish $S$.? bourgeoisii bourgeoisii from Crassostrea titan titan. Certainly the relationship of perrini is with bourgeoisii rather than with titan, and additional material may well prove perrini to be conspecific with bourgeoisii.

Geographic range.-Middle California.

Geologic range.-Miocene.

Occurrence in California.-Miocene: Briones Sandstone, San Pablo Group (Hall and Ambrose, 1916).

\section{Genus CRASSOSTREA Sacco, 1897}

Small to very large (to $60 \mathrm{~cm}$ high), outline very variable among individuals, but high, slender, spatulate forms with subparallel anterior and posterior margins seem most common. Surface rough, right valve with many nonappressed, irregularly spaced growth squamae, simple or frilled along free edges; left valve with poorly developed, discontinuous plicae. Shells very erodable and thickened in several ways. Umbonal cavity usually small. No chomata in post-larval shells. Adductor muscle imprint close to posterior valve margin and closer to ventral margin than to hinge; its outline has two fairly sharp corners and a nearly straight or concave dorsal margin.

The validity of the many specific and subspecific names proposed for Crassostrea, especially Miocene forms of C. titan titan, needs special attention. In this work, based almost wholly on type material, the validity of the many names proposed is not always challenged nor are they synonymized. Large collections of Crassostrea from as many different environments as are represented in a single formation spanning a short time interval need to be carefully studied and compared with living populations of Crassostrea. Logic as well as observation dictates that oysters crowded together will respond to that crowding in their growth form. Stanton (1966, p. 26) has discussed the variability in morphology of $C$. titan from north to south within the Miocene Castaic Formation.

Geographic range.-Living along the shores of most continents and of larger islands nearby (Antilles, Borneo, Philippines, Japan) but not south of the equator (Harold W. Harry, written commun., 1983).

Geologic range.-Cretaceous to Holocene (table 10).

Habitat.-Mostly in constant brackish water but may live in hypersaline conditions in the tropics. Usually in shallower water than all other oysters. Intertidal zone and to shallow depths in estuarine conditions, protected from strong wave action but with strong tidal currents. The living species, although essentially tropical, do not seem to live south of the equator, and $C$. gigas and $C$. virginica extend into temperate and even into cool waters. (Harold W. Harry, written commun., 1983)

\section{Crassostrea titan (Conrad)}

Plate 23, figures 1-7; plate 24, figures 1, 3, 4, 6; plate 27, figure 4; plate 28, figures 3,5 ; plate 29 , figures 1,6

Ostrea titan Conrad, 1853, p. 199-200. Conrad, 1857b, p. 72, pl. 4, fig. 17; pl. 5, fig. 17a. Arnold, 1907a, p. 543, pl. 45, fig. 2. Arnold, 1909, pl. 5, fig. 1; pl. 10, fig. 5; pl. 11, fig. 2. Clark, 1915, pl. 44, fig. 1. Grant and Eaton in Eaton, Grant, and Allen, 1941, pl. 4, fig. 2. Hanna and Hertlein, 1943, fig. 63-14. Addicott, 1965, p. C103, fig. 3a.

Ostrea titan titan Conrad. Adegoke, 1969, p. 109, pl. 5, figs. 1, 8. Ostrea (Crassostrea) titan Conrad. Dall, 1909, p. 111. 
TABLE 10.-Geologic and geographic distribution of the genus Crassostrea in the eastern Pacific region

$[\mathrm{H}=$ Holocene; $\mathrm{Pl}=$ Pliocene; $\mathrm{M}=$ Miocene; $\mathrm{O}=$ Oligocene $]$

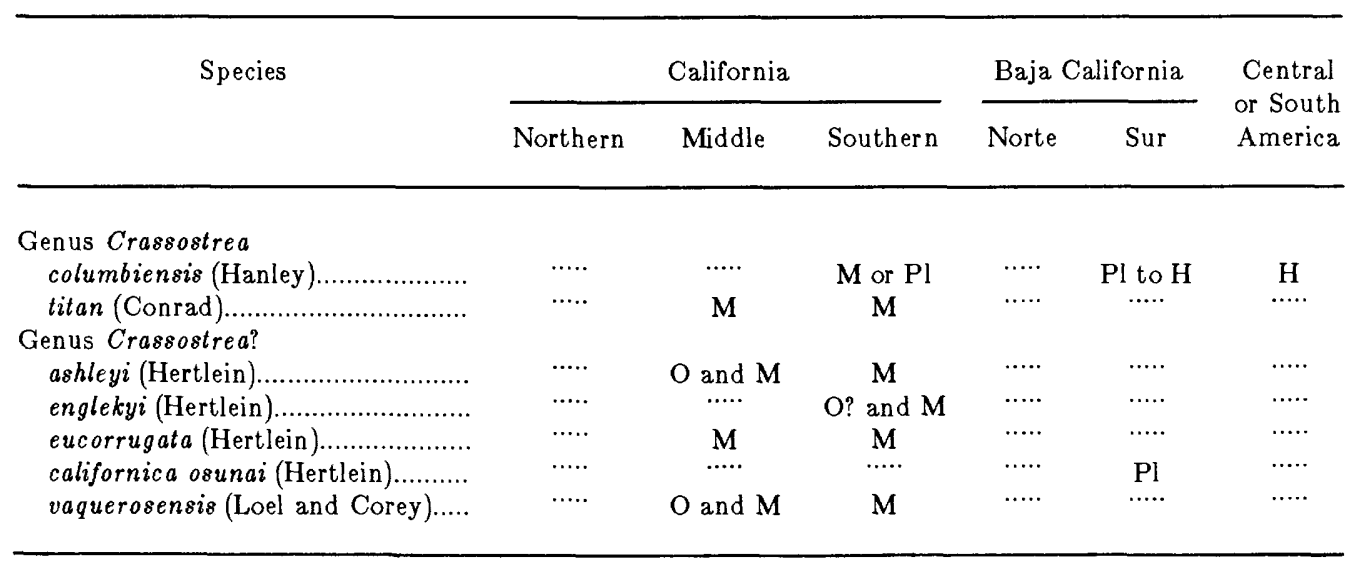

Crassostrea titan (Conrad). Stanton, 1966, p. 26-27. Stenzel, 1971, p. N973, figs. J14, 1a-1c.

Ostrea subjecta Conrad, 1857c, p. 193, pl. 2, fig. 3.

Ostrea panzana Conrad, 1857c, p. 193, pl. 2, fig. 4.

Ostrea ligminuta Grant and Eaton in Eaton, Grant, and Allen, 1941, pl. 4 , fig. 1 .

Ostrea titan prior Grant and Eaton in Eaton, Grant, and Allen, 1941, pl. 4 , fig. 2 .

Ostrea titan Conrad andersoni Adegoke, 1969, p. 110, pl. 5, figs. 2, 3, 6; pl. 6, fig. 1.

Not Ostrea titan Conrad. Arnold, 1907a, pl. 40, fig. 2 [= Ostrea titan subtitan Loel and Corey].

Original description.- -Elliptical or oblong; extremely thick and ponderous, contracted toward the hinge; ligament cavity profound; upper valve slightly arched; surface coarsely laminated. Length $10^{1 / 2}$ inches. Locality, San Luis Obispo, Cal." (titan titan)

"Very irregular, valves sometimes subplicated; cardinal area broad and carinated laterally; cartilage pit but slightly impressed. Locality, between Santa Clara River and Los Angeles Valley, on the Sierra Monica. Height, 2 inches. (in pl. 2 this fossil is improperly included under the $O$. panzana)." (subjecta)

"Ovate, thick, lower valve with a few lateral distant radiating plicae; upper valve thick, concentrically undulated and rugose; hinge area wide and carinated on the margins. Localities, Panza and Estrella valleys. Height, $2^{3 / 4}$ inches. The hinge of this shell resembles that of the preceding [subjecta]; and possibly, it may be the old shell of that species, the specimens of which, in the collection, are evidently all young shells. At Gaviote [Gaviota] Pass specimens of $O$. panzana occur twice the size of those from the above localities." (panzana)

"This species, where previously found, has probably been classified as either an immature $O$. titan or an unusually thick-shelled $O$. bourgeoisii. Averages 6 or 7 inches in length; some specimens attain 9 inches. Ligamental pit, minute in proportion to the exceedingly thick equal valves, averages about $5 / 8$ inches in width, and ranges from 1 to 3 inches in length. $O$. ligminuta differs from $O$. titan in its relatively much narrower, in some individuals curved, ligamental pit, even more prodigiously thick valves, commonly thicker than wide, and normally smaller size. Also, the laminae or shell layers as seen in cross section are strongly curved instead of relatively straight, which gives it its extreme thickness in proportion to width. Then too, the beak is thick, massive, broadly rounded, and in most specimens protrudes beyond the ligamental pit. From $O$. bourgeoisii of somewhat similar over-all length and ligamental pit it differs in its extremely thick and massive valves, which are essentially straight instead of curved, its remarkably small body cavity, and relatively smooth growth lamellae. It has no resemblance whatever to the ornate, plicated, thin-shelled, largecavitied $O$. cierboensis having a broad, short flattish ligamental pit, but is the opposite in all of these attributes. The range of $O$. ligminuta overlaps that of $O$. titan var. prior, which latter form, less massive, has the broad, straight ligamental pit, relatively flat laminae, and other characteristics of $O$. titan. The average specimen, which is near the holotype in size and medial thickness, has a heavier, more protruding beak than is exhibited by the somewhat worn type. Known range: late upper Briones, and lower and middle Cierbo." (ligminuta)

"Fragment of upper (right) valve showing convex ligamental callous of $O$. titan character, and even, flattish growth lamellae at the margins. In nearly all observed respects except size $O$. titan. Presumably ancestral to that gigantic Neroly form. Averages 6 or 7 inches in length. Differs from O. titan in having little more than half the length, and thus only a fraction of the mass, of the latter. Since both typical $O$. titan and this ancestral variety are commonly found in quantity, the markedly smaller size is quite diagnostic. Where previously observed has presumably been classified as the young of $O$. titan. Known range: late middle and upper Cierbo." (prior)

"Shell medium, thin, sub-trigonal; composed of many thin, platy calcite layers; valve relatively long, extremely narrow at cardinal area, becomes progressively broader ventrally; shell surface flat or gently concave; ligamental groove and ridge long and relatively narrow, bordered by narrow margins." (andersoni)

Holotype.-Missing and presumed lost; of panzana USNM 13338; of subjecta USNM 13338; of ligminuta UCLA 8985; of prior UCLA 8991; of andersoni UCMP 36661.

Type locality.-San Luis Obispo [County], Calif., Santa Margarita Formation, Miocene; of panzana, Panza and Estrella Valleys, San Luis Obispo County, Calif., Miocene; of subjecta, between Santa Clara River and Los Angeles Valley, on the Sierra Monica; of ligminuta, UCLA 1795, Santa Barbara County, Calif., Branch Canyon Sandstone, Miocene; of prior, UCLA 1745, Santa Barbara County, Calif., Branch Canyon Sandstone, Miocene; of andersoni, UC-D701, Fresno County, Calif., Santa Margarita Formation, Miocene.

Supplementary description.--"Produced from beak to base, straight or slightly curved, substance very thick, coarsely laminated; upper valve flat, very thick, somewhat gibbous; lower valve profoundly ventricose, umbonated, the summit rising above beak of the opposite valve." (Conrad, 1857 b, p. 72 )

According to Takeo Suzuki (written commun., 1982), specimens of $C$. titan in the Topanga Formation vary considerably in outline. They are high, narrow, and thick valved in reef-type occurrence and thick valved but not so elongate as when they grow in an uncrowded environment. The valves are usually unequal; one is flat or nearly flat and the 
other thick and arched. Crassostrea titan has a broad, straight, somewhat half-cylinder shaped resilifer with an accompanying resilifer trough. Striostrea? bourgeoisii bourgeoisii (Rémond) has a narrow slightly curved resilifer in the early growth stage which changes abruptly into the broad, straight form.

"The species varies considerably in abundance and morphology from north to south within the Castaic Formation. In the northern part of the formation, the species is more abundant and individuals are much larger than in the southern part. The average dimensions of specimens from north of San Francisquito Canyon are: length $30 \mathrm{~cm}$., width $10 \mathrm{~cm}$., and valve thickness $3 \mathrm{~cm}$. The average dimensions of specimens from the southern part of the formation are: length $15 \mathrm{~cm}$., width $8 \mathrm{~cm}$., valve thickness $2 \mathrm{~cm}$. Some valves from the southern part bear three to five irregular, round-crested ribs which may be discontinuous between laminae. Ribbing is more prevalent on left valves and particularly on those that are deeply cupped. Right valves are generally flat without ribbing." (Stanton, 1966, p. 26)

"C. titan has been reported from middle and upper Miocene strata of central and southern California. Eaton, Grant, and Allen (1941) describe from Miocene strata of the Caliente Range [Cuyama Valley] a number of new species and a new subspecies of $C$. titan from material that would have been grouped previously under $C$. titan. In addition, three other varieties or subspecies of $C$. titan have been described. In the Castaic Formation, in strata that are contemporaneous, morphologic variability is so great that, according to the illustrations and descriptions of type specimens, several of the previously described species and subspecies could be identified among the Castaic specimens. Most shells found in the northern part of the formation correspond to typical C. titan; some thick specimens could be classified as the species $C$. ligminuta. The largest specimens from the southern part of the outcrop area of the Castaic Formation are eight to ten inches long and thus would correspond to C. titan var. prior, which differs from $C$. titan only in being about half the size, and in being presumably ancestral to it. Ribbed specimens differ from the species C. bourgeoisii, as described and illustrated by Clark (1915, p. 447, pl. 43 ) and by Eaton, Grant and Allen (1941, pl. 3, fig. 1) in lacking the elongate narrow ligamental pit. They differ from the species $C$. cierboensis in having ribs that are narrow rather than broad and rounded. Ribbing, along with decrease in size and abundance, presumably reflects an environment to the southeast less hospitable for the species than to the northwest. The morphologic changes coincide with the change in environment from embayment in the north to open coast in the southeast." (Stanton, 1966, p. 27)

Comments.-Stanton (1966, p. 27) and Takeo Suzuki (written commun., 1982) have called attention to the fact that $C$. titan shows marked variability in ribbing, maximum size, thickness, and shape and that this variability relates to the environment in which they grew. In addition, John G. Vedder (written commun., 1983) said that he had seen literally thousands of specimens of $C$. titan along the south side of Cuyama Valley and that no two specimens were alike. He added that the same is true for myriads of specimens in the San JuanEstrella Creek area. Variability of Crassostrea is discussed under the generic heading above.

The holotypes of Ostrea subjecta Conrad and Ostrea panzana Conrad both have the same catalogue number, USNM 13338. They are both poorly preserved, have generalized locality data, and neither name has been used subsequently, to my knowledge. Woodring (1931, p. 386) said that the holotype of Ostrea panzana is free of matrix and probably represents a small specimen of Crassostrea titan Conrad. I see no reason for burdening the literature with these two specific names so I have synonymized them with $C$. titan.

The holotype of $O$. ligminuta is a worn, sponge-bored valve, $150 \mathrm{~mm}$ high, $170 \mathrm{~mm}$ long, and $170 \mathrm{~mm}$ thick. It has no distinctive shell chambers. Ostrea titan prior is distinguished from Ostrea titan only on the basis of size; it is the young of $O$. titan.
The holotype and paratype of Crassostrea titan andersoni Adegoke are worn, incomplete right valves. The holotype is poorly preserved and at least half of the original shell is missing. The paratype is not so poorly preserved as the holotype, but much of its shell is missing also. Adegoke (1969, p. 110) distinguished his subspecies from C. titan and other described subspecies on the basis of its relatively longer, narrower shell. The two right valves are not longer than right valves of $C$. titan: they only seem narrower because so much of the shell is missing. On the basis of the type material, $C$. titan andersoni is here synonymized with $C$. titan. Stenzel $(1971$, p. 127$)$ placed titan in Crassostrea.

Geographic range.-Middle and southern California.

Geologic range.-Miocene.

Occurrence in California.-Miocene: Branch Canyon Sandstone (Vedder, 1973), Castaic Formation (Stanton, 1966), McLure Shale Member, Monterey Formation (Adegoke, 1969), Modelo Formation (Dehlinger and Jennings, 1952; Oakeshott, 1958), Neroly Sandstone (Eaton, Grant, and Allen, 1941; Weaver, 1949), Round Mountain Silt (Addicott, 1965), San Pablo Formation (Clark, 1915), Santa Margarita Formation (Fairbanks, 1904; Hill, Carlson, and Dibblee, 1958; Adegoke, 1969; Squires and Fritsche, 1978; Addicott and others, 1978), Sobrante Sandstone (Weaver, 1953), and Topanga Formation (Arnold, $1907 \mathrm{c}$; Vedder, written commun., 1978).

\section{Crassostrea columbiensis (Hanley)}

Plate 24, figure 2; plate 26, figure 2; plate 28, figures 1, 2, 4

Ostrea columbiensis Hanley, 1846, p. 187.

Ostrea (Crassostrea) columbiensis Hanley. Olsson, 1961, p. 172, pl. 23, figs. $4,4 \mathrm{a}$.

Ostrea corteziensis Hertlein, 1951b, p. 68-73, pl. 24, figs. 1, 2; pl. 25, fig. 7. Keen, 1971 , p. 82, fig. 170.

Ostrea chilensis Phillipi. Durham, 1950, p. 58, pl. 4, fig. 1; not Ostrea chilensis Phillipi, 1844.

Crassostrea corteziensis (Hertlein). Bernard, 1983, p. 23.

Ostrea iridescens Gray. G D. Hanna, 1926a, p. 468, pl. 26, figs. 4-7. Not Ostrea iridescens Gray, 1854.

Ostrea californica Marcou. Hanna and Hertlein, 1927, p. 46. Grant and Gale, 1931, p. 149. Not Ostrea californica Marcou, 1858.

Original description.- - Ost. testa subinequivalvi, subtenui, lamellosa, albida, purpureo radiata, subcompressa; valvula inferiore magis convexa; superficie interna albida, submargaritacea; cardine denticulis nullis munito; cicatrice satis magna reniformi."(columbiensis)

"Shell elongately ovate to subtrigonal in outline, moderately thick, beaks turned posteriorly; lower (left) valve moderately convex, upper valve flattish or gently convex; early portion of upper valve with 8-10 weak, scaly, radiating costae ending about $75 \mathrm{~mm}$. from the beak, the remainder of the shell concentrically lamellose with faint traces of superficial radial sculpture, colored grayish-white to brownish-white, the brownish color more pronounced on juvenile shells; interior of lower valve with a large rather broad, ligamental area which is lightly transversely grooved, about 4 of these coarser than the others, the ligamental area is bordered on each side by a narrow groove; the anterior portion of the ligamental area centrally overhangs the body cavity; adductor muscle impression posteriorly situated, broadly semi-crescentic above, white with traces of purplish-brown concentric bands or lines; the remainder of the interior white with occasional traces of purplish-brown. Upper (right) valve usually flat or nearly so, exteriorly it is similar to the lower valve in coloration but it lacks the indistinct radiating furrows; interiorly the anterior portion of the ligamental area is raised centrally; adductor impression a little larger than that of the lower valve and truncated above by white shell mate- 
rial. Holotype: height, $153 \mathrm{~mm}$.; width (maximum), $98 \mathrm{~mm}$.; convexity (both valves together), approximately $56 \mathrm{~mm} . "$ (corteziensis)

Holotype.-In Museum Cuming; of corteziensis CAS 4288.

Type locality.-St. Elena, west Columbia; of corteziensis CAS 28186. Bahía Kino, Golfo de California, Sonora Mexico. Holocene.

Supplementary description.-- "Elongate, somewhat triangular, with a wide ligamentary area, rather flat. The surface shows faint radial furrows. $* * *$ This species $* * *$ was long known as $O$. chilensis Philippi, 1844, a mis-identification; for Chilean specimens show a rounded shape and denticles along the hinge margin." (Keen, 1971, p. 82)

"All the specimens I have seen are attached by the entire surface of the lower valve. The shape varies from oblong to suborbicular, and the valves are of equal length, but the shelly substance of the shallow upper valve fits into the lower one, and is only continued to the margin by the lamellae, which, when the habitat permits, branch into wavy foliations." (Hanley, 1846, p. 187)

"This species [O. corteziensis] has generally been referred by various authors to Ostrea chilensis Philippi. That species was originally described from Chile. ${ }^{* * *} 9$ to 10 denticles or traces of such, are present on specimens of $O$. chilensis from Calbuco, Chile. ${ }^{* * *}$ No trace of such denticles has been observed on any of the specimens studied from the Gulf of California. The base of the hinge of the upper valve of the Chilean shells does not possess such a large transverse ridge." (Hertlein, 1951b, p. 68-69)

"Shell relatively small (length to about $90 \mathrm{~mm}$.), very irregular, the attached valve deep, cup-shaped, the upper valve smaller and generally flattened. Sculpture smooth or with crudely formed ribs."(Olsson, 1961, p. 172.)

Comments.-Harold W. Harry (written commun., 1983) called my attention to the fact that $O$. corteziensis is a junior synonym of $O$. columbiensis.

Geographic range. - Living: Golfo de California to Ecuador; fossil: southern California to Baja California Sur.

Geologic range.-Miocene(?); Pliocene to Holocene

Occurrence in the Californias.-Miocene or Pliocene: Imperial Formation (Stump, 1979); Pliocene: Gloria (Stump, 1979) and San Marcos (Durham, 1950) Formations.

Habitat.-Generally attached to roots of mangroves; adhering to rocks at low tide.

\section{Genus CRASSOSTREA?}

\section{Crassostrea? vaquerosensis (Loel and Corey)}

\section{Plate 21, figure 2; plate 25, figure 2}

Ostrea vaquerosensis Loel and Corey, 1932, p. 192, pl. 19, figs. 1a, 1b Addicott, 1965, p. C104, fig. 3g.

Original description.- "Shell large and heavy, nearly round or slightly higher than long, nearly equivalve, upper valve more convex than lower; beaks rounded and slightly curved, exterior of shell with out ornamentation other than concentric, fairly prominent growth ridges; muscle scar round, located posteriorly. Height, $190 \mathrm{~mm}$.; width $170 \mathrm{~mm}$.; diameter (through both valves), $90 \mathrm{~mm}$."

Holotype.-CAS/SU 617; missing and presumed lost; paratypes CAS 6789, 6790 .

Type locality.—Jeff Harris Ranch, west of Pleyto [T. 24 S., R. 9 E.], Bryson Quad., Monterey County, Calif. Vaqueros Formation, Oligocene and Miocene.

Comparison.- "This species is distinct from $O$. titan in its constant roundness and equality of valves." (Loel and Corey, 1932, p. 192)

Geographic range.-Middle and southern California.
Geologic range.-Oligocene and Miocene. Eaton and others (1941, p. 199 ) said that $C$. vaquerosensis is restricted to the uppermost Vaqueros and aids in zoning the Vaqueros substage.

Comments.-The generic assignment is uncertain and C.? vaquerosensis may be a variant of C. titan.

Occurrence in California.-Oligocene and Miocene: Mindego Basalt (Cummings and others, 1962); Miocene: Jewett Sand (Addicott, 1965), Painted Rock Sandstone Member, Vaqueros Formation (Loel and Corey, 1932), Pyramid Hill Sand Member, Jewett Sand (Park and others, 1963).

\section{Crassostrea? englekyi (Hertlein)}

Plate 20, figure 1; plate 22, figure 1

Ostrea englekyi Hertlein, 1928, p. 143-144, pl. 25, fig. 1. Loel and Corey, 1932, p. 190, pl. 15, fig. 3. Bereskin and Edwards, 1969, p. 77, pl. 32, figs. $4 \mathrm{a}, 4 \mathrm{~b}$.

Original description.- "Shell elongate triangular. Lower valve thick, made up of flattish layers of shell material, thickest in middle part of valve; sides of valve fairly straight. Left valve thinner but otherwise similar to right valve. Altitude $143.4 \mathrm{~mm}$; ; width of ventral margin of shell $86 \mathrm{~mm} . "$

\section{Holotype.-CAS 4116 .}

Type locality._CAS 1156. Santa Barbara County, Calif. Temblor [upper part of Vaqueros] Formation of Loel and Corey, 1932; San Onofre Breccia of Bereskin and Edwards, 1969, Miocene.

Comparison.- "The hinge of Ostrea englekyi is not fully exposed but it apparently belongs to the Ostrea virginica Gmelin group. It differs from that species in its extremely triangular shape, straight sides and thick shell. From $O$. freudenbergi Hertlein and Jordan, $O$. englekyi differs in its larger size, greater thickness and straight sides and different hinge. The present species is apparently not close to $O$. chilensis Philippi in the early part of shell nor in general shape. $O$. englekyi most closely resembles a species of recent Ostrea which is found in the Gulf of California apparently differing only in minor details. The triangular shape, narrower ligament pit and wider anterior margin distinguish $O$. englekyi from $O$. californica Marcou, a species once reported by Hanna [1926a, p. 468] as $O$. iridescens Gray but later [M. A. Hanna and Hertlein, 1927, p. 45-47] recognized as distinct from Gray's recent species." (Hertlein, 1928, p. 143-144)

Comments. - The holotype of C.? englekyi is a double-valved specimen with the valves together and closed. The specimen is worn and was originally somewhat wider at the umbonal end and thus not "extremely triangular" as stated by Hertlein (1928, p. 143). The straight steep sides of the left valve are distinctive and may not simply relate to where it grew. The edges of the shell layers on the left valve may have been fluted. The right valve is smooth and flat to concave. On the basis of the holotype, the generic assignment is uncertain.

Geographic range.- Southern California.

Geologic range.-Oligocene(?); Miocene.

Occurrence in California.-Oligocene and Miocene: Vaqueros Formation (Bereskin and Edwards, 1969); Miocene: Temblor Formation (Hertlein, 1928) and upper part of Vaqueros Formation (Loel and Corey, 1932).

\section{Crassostrea? ashleyi (Hertlein)}

Plate 19, figures 3, 5; plate 20, figures 2-6; plate 21, fig. 3; plate 22, fig. 2; plate 24, fig. 5 .

Ostrea ashleyi Hertlein, 1934b, p. 1, 3, pl. 1, figs. 2, 3; pl. 2, fig. 1. Adegoke, 1969, p. 107-108, pl. 4, fig. 5. Addicott, 1965, p. C106, fig. 4q. 
Ostrea altatemblorensis Grant and Eaton in Eaton, Grant, and Allen, 1941, pl. 2, fig. 2 [described in plate explanation].

Ostrea arnoldi Adegoke, 1969, p. 106-107, pl. 4, figs. 1, 2, 6, 9; pl. 5, fig. 5. Ostrea hertleini Adegoke, 1969, p. 108, pl. 4, figs. 3, 4; pl. 5, fig. 4; pl. 6, fig. 9.

Original description.- "Lower valve narrowly oblong, wider at base; exteriorly ornamented by numerous fluted ribs; area of attachment near beak unornamented. Interior of margin not folded; muscle scar fairly large; ligament groove long and fairly wide. Upper valve long and narrow; on the interior beneath the beak a long narrow elevated area is present which fits into the groove of the lower valve. Height of shell (beak to base, incomplete); $216 \mathrm{~mm}$.; width of shell (at base) $108 \mathrm{~mm}$." (ashleyi)

"Lower (left) valve. Average length about 6 inches; width commonly from a third to a half of this. Lower valve moderately thick, with 5-8 characteristically narrow, somewhat angular, rather evenly spaced, in many specimens almost knife-edge, radial ribs separated by rounded trough-like interspaces which may bear minor riblets. Upper (right) valve thinner, flattish, with irregular, concentric growth rugosities, but without definite continuous radial sculpture. Ligamental pit of lower valve concave, elongate, tapering, and ordinarily curved. Differs from $O$. wiedeyi of the older Miocene in its fewer, narrower plications, and the wide, rounded troughs between these. Differs from the Pliocene species $O$. vespertina in all of the foregoing attributes, and in its more elongate shape, larger size, and thicker valves." (altatemblorensis)

"Shell medium sized, oval to subcircular, not constricted at hinge area, valves moderately thick, composed of several thin flat laminae; outer surface rather smooth, often faintly corrugated or with rather indistinct ornamentation; ligamental groove ralatively short, often less than one-sixth length of shell, rather broad, with broad raised margins; interior of shell evenly concave, except in area immediately adjacent to ligamental groove where it is deep; muscle scar large, impressed, with a semicircular outline, ventral margin broadly rounded, anterior margin almost straight; muscle scar located on anterior edge of shell about a third of length from the ventral margin, displaced toward 'dorsal' margin; both valves equally inflated." (arnoldi)

"Shell long, narrow, only slight change in diameter from anterior to posterior end; left valve heavy, thick, convexly arched; right valve thin, flat anteriorly, concave posteriorly; growth lines more distinct on right than on left valve; ligamental groove short, narrow, bounded by relatively wide, flat margins; ligamental groove narrow but fairly deep, deeper on left valve; adductor muscle scar not very distinct, subcircular in outline, centrally placed, about midway in valve; shell straight to slightly curved, ventral margin gently rounded, anterior margin bluntly acute; dorsal margin almost straight." (hertleini)

Holotype.-CAS 6065; of altatemblorensis UCLA 8970; of arnoldi UCMP 36646; of hertleini UCMP 36654.

Type locality.-CAS 933. Kern County, Calif. Temblor Formation, Oligocene and Miocene; of altatemblorensis UCLA 512, San Luis Obispo County, Calif. Branch Canyon Sandstone, Miocene; of arnold UC D-1075. Fresno County, Calif. Temblor Formation, Oligocene and Miocene; of hertleini UC D-1057. Kings County, Calif. Temblor Formation, Oligocene and Miocene.

Comparison.- "This long narrow oyster with pronounced ribs ornamenting the lower valve, which bears a long ligament groove, internally, is quite distinct from any other species from western North America. These features of the lower valve as well as the long narrow upper valve with the internally raised area below the beak, easily distinguish the species from other lower Miocene forms such as $O$. loeli Hertlein, $O$. wiedeyi Hertlein, and $O$. howelli Wiedey." (Hertlein, 1934b, p. 1-2)
"Ostrea ashleyi Hertlein is characterized by an elongate, narrow ligamental groove, similar to that of $O$. bourgeoisii to which it has been referred by several workers. It differs from $O$. bourgeoisii by its much smaller size, thin valves, and relatively large semicircular muscle scar. It was described from the Temblor of Kern County. The species occurs abundantly in an 8-foot oyster bed in the middle of the Temblor Formation of the Coalinga region." (Adegoke, 1969, p. 108)

Comments. - The holotype of C.? ashleyi is a fairly large, somewhat worn left valve. The exterior is sculpted by irregular ribs that are somewhat fluted. The muscle impression is semiovate and the ligamental area is large. The deep resilifer is bordered anteriorly by a prominent bourrelet (area flanking resilifer) and posteriorly by a bourrelet projecting upwards at an angle of about $45^{\circ}$. The body cavity is shallow.

The left valve holotype of $O$. altatemblorensis has narrow, sharpedged plicae or folds that are irregularly nodose and separated by shallow, U-shaped interspaces.

The right valve holotype of Ostrea arnoldi is small and the exterior very worn. Some of the exposed shell layers show traces of fine, radial ribs, suggesting Striostrea. The left valve paratype of $O$. arnoldi is small and badly worn; it does not have traces of radial ribs as are present on C.? ashleyi.

The holotype of Ostrea hertleini is a double-valved specimen with the valves together and closed. It is small and relatively narrow. The left valve, although very worn with the outer shell layers missing, seems to have had fluted ribs. The left valve is smooth, worn, and flat to concave.

Geographic range.-Middle and southern California.

Geologic range.-Oligocene and Miocene.

Occurrence in California.-Oligocene and Miocene: Temblor Formation; Miocene: Branch Canyon Sandstone (Hill and others, 1958; Vedder, 1973; Adegoke, 1969) and Olcese Sand (Addicott, 1965).

\section{Crassostrea? eucorrugata (Hertlein)}

\section{Plate 25, figures 3-5; plate 26, figure 1; plate 27, figure 1}

Ostrea titan corrugata Nomland, 1917, p. 306, pl. 16, fig. 1; pl. 17, fig. 1. Not Ostrea corrugata Brocchi, 1814; not Ostrea corrugata Hutton, 1873.

Ostrea titan eucorrugata Hertlein, 1934b, p. 5, new name. Ostrea titan Conrad eucorrugata Hertlein. Adegoke, 1969, p. 109.

Ostrea cierboensis Grant and Eaton in Eaton, Grant, and Allen, 1941, pl. 3, fig. 2 .

Original description.- - "Shell large, very heavy, when full grown sub-ovate but in earlier stages of very irregular outline. Surface sculptured by well marked growth lines which at the edges are irregularly folded into prominent radiating ridges. Ligamental groove wide, triangular, extending nearly across anterior end of shell. Muscular impression large, rectangular, almost invisible in type. Dimensions of lower valve: length $235 \mathrm{~mm}$.; width, $150 \mathrm{~mm}$; height, $120 \mathrm{~mm}$." (corrugata)

"View showing lower (left) valve. Averages 5-6 inches in length and about 4 in width. Differs from all other known large upper Miocene oysters of California in being nearly as wide as long, and in having broad, somewhat regular radial plications on the lower valve. Upper (right) valve thin and flattish. Moderately thin-shelled, large-cavitied with a broad, very short, flattish ligamental pit commonly about 1 inch wide and 1/2 inch long. Well preserved specimens normally occur as inatched valves. Has probably previously been erroneously identified as the smaller and younger species $O$. vespertina (Pliocene). Differs from the latter species in its larger size, thicker shell and fewer, broader plications." (cierboensis) 
Holotype.-UCMP 11309; of cierboensis UCLA 8980.

Type locality.-UC 2284. Fresno County, Calif. Santa Margarita Formation, Miocene; of cierboensis UCLA 1751, Santa Barbara County, Calif., Cierbo Formation [Branch Canyon Sandstone], Miocene.

Comparison.- "Distinguishable from the typical Ostrea titan Conrad which is also found in the Santa Margarita Formation by the prominent folds on surface and the greater convexity of lower valve." (Nomland, 1917, p. 306)

Comments.-The growth lamellae are fluted at their edges, thick at their base but almost paper thin at their free margin, and where broken across are seen to be built of thick, prismatic calcite crystals. On the basis of the growth lamellae (Stenzel, 1949, p. 35-36), the holotype specimen was at least 8 years old. Almost the entire exterior and interior surfaces of the left-valve holotype show pseudovesicular structure. Stenzel $(1971$, p. N987) illustrated true honey-comb vesicular structure and used this character to identify the Pycnodonteinae. Cross sections of the prismatic shell layer produced at shell breaks show only the vertical prismatic crystals and no internal vesicular layers. Thus the pseudovesicular structure, which is believed to be a solution artifact, consists of small pits conforming to the size of the sand grains, some of which are still attached. The pits were caused by leaching of the shell.

Shell characters of $C$.? eucorrugata that make assignment of the species to Crassostrea dubious are: the ligamental area of the left valve is longer than high and the left valve has thick, prismatic shell layers. These two characters suggest Fleminostrea, but $C$.? eucorrugata has a beaked left valve umbo, the left valve is highly convex, and the valves are not nearly equal in size. No vesicular shell structure was seen, but $C$.? eucorrugata may belong in the subfamily Pycnodonteinae.

Geographic range.-Middle and southern California.

Geologic range.-Miocene.

Occurrence in California.-Miocene: Branch Canyon Sandstone (Eaton, Grant, and Allen, 1941; Vedder,1970) and Santa Margarita Formation (Nomland, 1917; Wilson, 1944; Addicott and Vedder, 1963).

\section{Crassostrea? californica osunai (Hertlein)}

\section{Plate 27, figure 2}

Ostrea californica osunai Hertlein, 1966, p. 272-273, figs. 2-6, 8, 9.

Original description.- -Shell, a left valve, elongated, longer than wide, thick with uneven, wavy growth laminae; exterior flattish, lacking ornamentation; interior with a shallow body cavity; ligamental pit rather wide, concave, elongate, the laminae of growth form a nearly straight line across the pit; muscle impression on the type specimen indistinct, apparently at about one third the length of the shell from the ventral margin. Dimensions: Length (apex lacking), $393 \mathrm{~mm}$., maximum width, $140 \mathrm{~mm}$., maximum thickness, $84 \mathrm{~mm}$.

"Right valve, a paratype, ventral portion lacking; a raised, convex ridge corresponds to the ligamental pit of the opposite valve. Dimensions; length (ventral portion lacking), $238 \mathrm{~mm}$., maximum width, 133 $\mathrm{mm}$., maximum thickness, $53 \mathrm{~mm}$."

Holotype.-CAS 12823.

Type locality.-CAS 38855. From the southwest end of Punta Concepcion, Baja California Sur. Salada Formation, Pliocene.

Comparison.-The dorsal half of two specimens of C. californica osunai, about $130 \mathrm{~mm}$ long, closely resemble specimens of $C$. californica s. s., differing only in the larger and thicker shell. One lower valve is recessed under the hinge, but other valves are not. Similar variability can be observed among specimens of $C$. californica $s$. s.. None of the valves of $C$. californica s. $s$. are as large and thick as those of $C$. californica osunai nor is the ligamental pit and corresponding ligamental ridge on the opposite valve as large as those on valves of $C$. californica osunai. Some of the large valves of C. californica osunai resemble Crassostrea bourgeoisii Remond, as illustrated by Clark (1915, pl. 43), but differ from that species in their much more elongate, narrower outline, and broader ligamental pit. (Hertlein, 1966, p. 273)

Comments. - The holotype is a double-valved specimen with the valves separated. The early portion (one-fourth) of the left valve is ribbed; the right valve is smooth.

Geographic range.-Baja California Sur.

Geologic range.-Pliocene.

Occurrence in Baja California.-Pliocene: Salada Formation (Hertlein, 1966).

\section{FOSSIL LOCALITIES}

[Corrections and information not in the original description are in brackets; feet and miles are converted to the metric system; formations are cited as emended by later workers, where pertinent]

California Academy of Sciences:

CAS 933. Center of sec. 32, T. 28 S., R. 29 E., Kern County, Calif. Temblor Formation.

CAS 945. Southeast of Bahía Tortola, Baja California Sur. Almejas Formation.

CAS 1150. West of Arlington Canyon, Santa Rosa Island, Santa Barbara County, Calif. Vaqueros Formation.

CAS 1154. Oyster bed near spring on ridge to south of San Augustine Canyon, about 1.6 to $2 \mathrm{~km}$ from mouth of canyon, Santa Rosa Island, Calif. Temblor Formation.

CAS 1156. About $0.4 \mathrm{~km}$ southeast of spring on ridge south San Augustine Canyon, east of dike near top of hill, Santa Rosa Island, Calif. Temblor Formation Miocene.

CAS 1163. East of Crook Point, San Miguel Island, Santa Barbara County, Calif. Vaqueros Formation.

CAS 5955. San Diego, Calif. Holocene.

Los Angeles Natural History Museum:

LAM 305. $730 \mathrm{~m}$ east and $310 \mathrm{~m}$ south of NW cor. sec. 8, T. $19 \mathrm{~S}$., R. 2 W., San Ysidro Quad. (1943 edition), [San Diego County], Calif. San Diego Formation.

Stanford University [All these collections are now in the California Academy of Sciences]:

SU 59. Turritella bed above San Gregorio Lagoon, $190 \mathrm{~km}$ north of Magdalena Bay, on the trail from Arroyo Mesquital to La Purisima, Baja California Sur. Isidro(?) Formation.

SU 446. Near Sespe Creek, $8.8 \mathrm{~km}$ northeast of Wheeler's Hot Springs, [sec. 32, T. 6 N., R. 22 W.], Mt. Pinos Quad., Ventura County, Calif. Temblor Formation.

SU 449. Val Celico, a little west of Pleyto, Monterey County, Calif. Vaqueros Formation.

University of California at Berkeley:

UC 790. East of Lower Lake village $1.2 \mathrm{~km}, 365 \mathrm{~m}$ south of Nerndon Creek bridge, $\mathrm{SE}^{1 / 4}, \mathrm{NE}^{1 / 4}$, sec. $11, \mathrm{~T} .12$ N., R. 7 W., Lake County, Calif. Martinez Formation.

UC 1131. Southwest of town of Walnut Creek $0.8 \mathrm{~km}$, in creek bed, Long. $122^{\circ} 4^{\prime} 8^{\prime \prime}$, Lat. 37 $53^{\prime} 7^{\prime \prime}$ [Concord Quad.], Contra Costa County, Calif. San Ramon Formation.

UC 1540. South of Stewartville $1.6 \mathrm{~km}, \mathrm{NE}$ cor. NW $1 / 4$ sec. $15, \mathrm{~T} .1$ N., R. 1 E., Mt. Diablo Quad., Contra Costa County, Calif. Martinez Formation.

UC 2284. Near middle of south boundary of NE1/4, sec. 10, T. $19 \mathrm{~S}$., R. 15 E., Fresno County, Calif. Santa Margarita Formation, Miocene.

UC 3752. Simi Valley, Santa Susana Quad., SE 1/4, SE⿺𠃊1/4, sec. 7, T. 2 N., R. 17 W., Ventura County, Calif. Martinez Formation. 
UC 3981. At $15 \mathrm{~m}$ above high tide level in small gully $0.4 \mathrm{~m}$ south of Soledad Valley, La Jolla Quad., San Diego County, Calif. La Jolla Group.

UC 5062. In sea cliff south of mouth of Soledad Valley, due west of midpoint between "P" and "u" of "Pueblo", La Jolla Quad., San Diego County, Calif. La Jolla Group, Eocene.

UC A-321. About $0.5 \mathrm{~m}$ due south of end of Santa Ynez River bridge, south of Santa Ynez Mission, on east side of Alisal Creek [Lompoc Quad., Santa Barbara County], Calif. Vaqueros Formation.

UC A-326. Upper end of San Antonio Creek Canyon, northwest of mouth of Lion Canyon, on west side, Ventura Quad., Ventura County, Calif. Vaqueros Formation.

UC A-336. On long sharp northwest spur of Oak Ridge $1.6 \mathrm{~km}$ east of Grimes Canyon [NW11/4 sec. 8, T. 3 N., R. 19 W., Piru Quad., Ventura County], Calif. Vaqueros Formation.

UC D-701. From $2+\mathrm{m}$ thick, prominent oyster and pecten "reef", the most prominent ledge-forming Ostrea-Pecten "reef" on the slope of the hills a few feet northwest of Shell Oil well 254-15. 2,460 feet north, 2,530 feet west, sec. 15, T. 19 S., R. 15 E., Domengine Ranch Quad., Fresno County, Calif. Santa Margarita Formation.

UC D-1057. 190 m north, 395 m west, sec. 3, T. 23 S., R. 16 E., Reef Ridge Quad., Kings County, Calif. Temblor Formation. From two prominent oyster beds about $3.5 \mathrm{~m}$ apart and from coarse sandstone bed below the lower oyster bed. Lateral extent of collection about $30 \mathrm{~m}$.

UC D-1075. Sec. 21, T. 19 S., R. 15 E., $745 \mathrm{~m}$ north and $215 \mathrm{~m}$ east, Domengine Ranch Quad., Fresno County, Calif. From approximately $2.5 \mathrm{~m}$ oyster bed in light gray and buff colored, fragile, silty shale. Fossil bed crops out for considerable distance along road on the west slope of the hills. Temblor Formation.

U.S. Geological Survey, Menlo Park, Calif:

USGS $3220.328 \mathrm{~m}$ north and $91 \mathrm{~m}$ west of SE cor. sec. 4, T. $7 \mathrm{~S}$., $R$ 8 W., San Juan Capistrano Quad. (1949 edition), altitude about $80 \mathrm{~m}$. On east bank of Aliso Creek, base of Monterey Shale. Lat. $33^{\circ} 35.3^{\prime} \mathrm{N}$, long., $117^{\circ} 47.7^{\prime} \mathrm{W}$, Calif. Monterey Shale.

USGS 3426. Third Street Tunnel, Los Angeles, Los Angeles County, Calif. Repetto Formation.

USGS 4715. South end of Kettleman Hills in sec. 10, T. 25 S., R. 19 E. [Lost Hills Quad., Kern County], Calif. Etchegoin Formation.

University of California at Los Angeles:

UCLA 512. Ridge between main and east Abbott Canyons, oyster bed $6+\mathrm{m}$ thick and $6 \mathrm{~m}$ conglomerate below. (Not found in bottom of canyon). [SW11/4 sec. 11 , T. 11 N., R. 27 W., McKittrick Quad., northeast slope of] Caliente Range, San Luis Obispo County, Calif. Upper Temblor Formation [Branch Canyon Sandstone].

UCLA 1745. Cuyama Valley, Branch Canyon, east of head of Discovery Gulch. On top of knoll, Zone 9, Santa Barbara County, Calif. Middle Cierbo Formation [Branch Canyon Sandstone].

UCLA 1751. About $350 \mathrm{~m} \mathrm{~S} 25^{\circ} \mathrm{E}$ from Branch Canyon along ridge west side Discovery Gulch. $18-22 \mathrm{~m}$ down the $16^{\circ}$ slope from prominent white sandstone reef which forms the strike ridge $\mathrm{N} 25^{\circ} \mathrm{W}$, along the weathered surface exposure of Ostrea cierboensis and Astrodapsis gregerseni. Oysters very abundant at southwest end of exposure above head of Discovery Gulch westward. South side Branch Canyon, Cuyama Valley, Santa Ynez Quad., Santa Barbara County, Calif. Cierbo Formation [Branch Canyon Sandstone].
UCLA 1795. Short Canyon branch of Bitter Creek. Reef at base of the Astrodapsis section exposed therein. Collected on west side of Short Canyon, from Ostrea reef interbedded with $A$. cf. tumidus. About $70 \mathrm{~m}$ below upper shale of this locality. [South side Cuyama Valley, Santa Ynez Quad., Santa Barbara County, Calif.] Cierbo Formation [Branch Canyon Sandstone].

University of California at Riverside:

UCR 6899. Light gray concretions with abundant oyster debris $134 \mathrm{~m}$ due east of small hill $1461 \mathrm{~m} \mathrm{NW} 11^{\circ}$ from hill 496 and $748 \mathrm{~m}$ southwest $5^{\circ}$ of hill $1331.928 \mathrm{~m}$ above base of Simi Conglomerate, Calabasas Quad., California.

University of Oregon:

UO 130. Near Glide, Douglas County, Oregon. Umpqua Formation.

University of Washington:

UW 160. Bluff at Porter Station in Northern Pacific Railroad cut, sec. 22, T. 17 N., R. 4 W., Grays Harbor County, Wash. Lincoln Creek Formation.

\section{GEOLOGIC FORMATIONS CITED FOR OCCURRENCE OF PELECYPODS.}

Family Plicatulidae to Family Ostreidae Name

Age

California:

Alegria Formation ${ }^{1}$

Anchor Silt ${ }^{1}$

Avenal Sandstone

Bay Point Formation

Beechers Bay Member

Monterey Formation ${ }^{1}$

Branch Canyon Sandstone

Briones Sandstone, San Pablo Group

Cañada Formation ${ }^{1}$

Capistrano Formation

Careaga Sandstone

Carlotta Formation

Castaic Formation ${ }^{1}$

Cebada Member, Careaga Sand or Sandstone

Oligocene

Pleistocene

Eocene

Pleistocene

Miocene

Miocene

Miocene

Eocene

Miocene and Pliocene

Pliocene

Pleistocene

Miocene

Pliocene

Cierbo Sandstone, San Pablo

Group

Miocene

Coldwater Sandstone and

Coldwater Sandstone

Member ${ }^{1}$, Tejon Formation

Cozy Dell Shale and Cozy Dell

Shale Member ${ }^{1}$, Tejon

Formation

Delmar Formation, La Jolla

Group

Domengine Formation or

Sandstone

Etchegoin Formation

Fernando Formation

Foxen Mudstone

Eocene

Eocene

Eocene

Miocene and Pliocene

Pliocene and

Pleistocene

Pliocene

${ }^{1}$ Stratigraphic nomenclature used is that of the references cited in the text and does not necessarily accord with that of the U.S. Geological Survey. 
Gaviota Formation ${ }^{1}$ Imperial Formation

Jewett Sand

Juncal Formation

La Jolla Group

Lomita Marl Member, San

Pedro Formation

Martinez Formation

Matilija Sandstone

Medill Sand ${ }^{1}$

Merced Formation

Mindego Basalt

Modelo Formation

Monterey Formation, Shale, or Group

Neroly Sandstone, San Pablo Group

Niguel Formation

Olcese Sand

Painted Rock Sandstone

Member, Vaqueros Formation

Palos Verdes Sand

Pancho Rico Formation

Paso Robles Formation

Pico Formation

Potato Harbor Formation ${ }^{1}$

Purisima Formation

Pyramid Hill Sand Member, Jewett Sand

Quail Canyon Sandstone

Member, Vaqueros Formation

Rincon Shale

Rose Canyon Shale ${ }^{1}$

Round Mountain Silt

Sacate Formation ${ }^{1}$

Saltos Shale Member, Monterey Formation

San Diego Formation

San Joaquin Formation

San Pablo Formation

San Pedro Formation or Sand

San Ramon Sandstone

Santa Margarita Formation

Santa Susana Formation ${ }^{1}$

Santos Shale Member, Temblor

Formation

Saugus Formation

Simi Conglomerate

Sisquoc Formation

Sobrante Sandstone

Soda Lake Sandstone Member,

Vaqueros Formation

Tejon Formation

Temblor Formation
Eocene and Oligocene Miocene or Pliocene

Miocene

Eocene

Eocene

Pliocene

Paleocene

Eocene

Pleistocene

Pliocene and

Pleistocene

Oligocene and

Miocene

Miocene

Miocene

Miocene

Pliocene

Miocene

Miocene

Pleistocene

Miocene

Miocene, Pliocene, and Pleistocene

Pliocene and Pleistocene

Pliocene

Miocene and Pliocene

Miocene

Oligocene and Miocene

Oligocene and Miocene

Eocene

Miocene

Eocene

Miocene

Pliocene

Pliocene

Miocene

Pliocene and Pleistocene

Miocene(?)

Miocene

Paleocene and Eocene

Oligocene and Miocene

Pliocene and Pleistocene

Paleocene

Miocene and Pliocene

Miocene

Oligocene and Miocene

Eocene

Oligocene and Miocene
Timms Point Silt Member, San Pedro Formation

Tomales Formation

Topanga Formation

Towsley Formation

Vaqueros Formation

Wygal Sandstone Member,

Temblor Formation

Baja California peninsula:

Almejas Formation

Boleo Formation

Cantil Costero Formation

Carmen Formation

Comondú Formation

Gloria Formation

Infierno Formation

Isidro Formation

Marquer Formation

Salada Formation

San Marcos Formation

San Ignacio Formation

Santa Rosalia Formation

Sepultura Formation

Tortugas Formation

Washington:

Cowlitz Formation

Oregon

Umpqua Formation

Dominican Republic:

Emperador Member, La Boca Formation

Gurabo Formation
Pleistocene

Pleistocene

Miocene

Miocene and Pliocene

Oligocene and Miocene

Oligocene

Pliocene

Pliocene

Pliocene

Pliocene

Miocene

Pliocene

Pliocene

Miocene

Pliocene

Pliocene

Pliocene

Pliocene

Pleistocene

Paleocene

Miocene

Eocene

Eocene

Miocene

Miocene

\section{REFERENCES CITED}

Addicott, W. O., 1965, Miocene macrofossils of the southeastern San Joaquin Valley, California: U.S. Geological Survey Professional Paper 525-C, p. C101-C109, 4 figs.

1972, Provincial middle and late Tertiary molluscan stages, Temblor Range, California, in Pacific Coast Miocene Biostratigraphic Symposium: Society of Economic Paleontologists and Mineralogists, Pacific Section, Bakersfield, California, 1972, Proceedings, 26 p., 4 pls., 3 figs., 5 tables.

1973, Oligocene molluscan biostratigraphy and paleontology of the lower part of the type Temblor Formation, California: U.S. Geological Survey Professional Paper 791, 48 p., 9 pls., 5 figs., 1 table.

Addicott, W. O., and Galehouse, J. S., 1973, Pliocene marine fossils in the Paso Robles Formation, California: U.S. Geological Survey Journal of Research, v. 1, no. 5, p. 509-514, 4 figs.

Addicott, W. O., Poore, R. Z., Barron, J. A., Gower, H. D., and McDougall, Kristin, 1978, Neogene biostratigraphy of the Indian Creek-Shell Creek area, northern La Panza Range, California, in Addicott, W. O., ed., Neogene biostratigraphy of selected areas in the California Coast Ranges: U.S. Geological Survey Open-File Report 78-446, p. 49-82, 4 pls., 12 figs.

Addicott, W. O., and Vedder, J. G., 1963, Paleotemperature inferences from late Miocene mollusks in the San Luis Obispo-Bakersfield area, California: U.S. Geological Survey Professional Paper 475C, p. C63-C68.

Adegoke, O. S., 1969, Stratigraphy and paleontology of the marine Neogene formations of the Coalinga region, California: Univer- 
sity of California Publications in Geological Sciences, v. 80, 241 p., $13 \mathrm{pls}$.

Allen, J. E., 1946, Geology of the San Juan Bautista Quadrangle, California: California Division of Mines Bulletin 133, p. 9-75.

Anderson, F. M., 1905, A stratigraphic study in the Mount Diablo Range of California: California Academy of Sciences Proceedings, ser. 3 , v. 2 , no. 2 , p. 155-248, pls. 13-35.

Anderson, F. M., and Hanna, G D., 1925, Fauna and stratigraphic relations of the Tejon Eocene at the type locality in Kern County, California: California Academy of Sciences Occasional Papers 11, 249 p., 16 pls., 10 text figs.

Arnold, Ralph, 1903, The paleontology and stratigraphy of the marine Pliocene and Pleistocene of San Pedro, California: California Academy of Sciences Memoirs, v. 3, 419 p., 37 pls.

1906, The Tertiary and Quaternary pectens of California: U.S Geological Survey Professional Paper 47, 264 p., 53 pls., 2 figs.

$1907 \mathrm{a}$, New and characteristic species of fossil mollusks from the oil-bearing Tertiary formations of southern California: U.S. National Museum Proceedings, v. 32 , no. 1545 , p. 525-546, pls. 38-51.

1907b, Geology and oil resources of the Summerland District, Santa Barbara County, California: U.S. Geological Survey Bulletin 321,93 p., 17 pls., 3 figs.

$1907 \mathrm{c}$, New and characteristic species of fossil mollusks from the oil-bearing Tertiary formations of Santa Barbara County, California: Smithsonian Miscellaneous Collections, v. 50, no. 4, p. 419-447, pls. 50- 58.

1909 [1910], Paleontology of the Coalinga District, Fresno and Kings Counties, California: U.S. Geological Survey Bulletin 396, 173 p., pls. 1-30.

Arnold, Ralph, and Anderson, Robert, 1907, Geology and oil resources of the Santa Maria oil district, Santa Barbara County, California: U.S. Geological Survey Bulletin 322, 161 p., 26 pls.

-1910 , Geology and oil resources of the Coalinga District, California: U.S. Geological Survey Bulletin 398, 354 p., 52 pls.

Avila, F. A., and Weaver, D. W., 1969, Mid-Tertiary stratigraphy, Santa Rosa Island [California], in Weaver, D. W., ed., Geology of the Northern Channel Islands: American Association of Petroleum Geologists and Society of Economic Paleontologists and Mineralogists, Pacific Sections, Special Publication, p. 48-67, pls. 32, 33.

Bailey, T. L., 1952, Summerland area, in Redwine, L. E., chairman, Cenozoic correlation section paralleling north and south margins [of the] western Ventura basin from Point Conception to Ventura and Channel Islands, California: American Association of Petroleum Geologists, Subcommittee on the Cenozoic of the Geologic Names and Correlations Committee, 2 sheets.

Baily, J. L., 1950, Locomotion in Lima: Nautilus, v. 63, no. 4, p. 112-113.

Beale, C. H., 1948, Reconnaissance of the geology and oil possibilities of Baja California, Mexico: Geological Society of America Memoir $31,138 \mathrm{p} ., 11 \mathrm{pls}$

Bereskin, S. R., and Edwards, L. N., 1969, Mid-Tertiary stratigraphy, southwestern Santa Cruz Island [California], in Weaver, D. W., Geology of the Northern Channel Islands: American Association of Petroleum Geologists and Society of Economic Paleontologists and Mineralogists, Pacific Sections, Special Publication, p. 68-79.

Bernard, F. R., 1979, Bivalve mollusks of the western Beaufort Sea: Natural History Museum of Los Angeles County, Contributions in Science No. 313, 80 p., 112 figs.

1983, Catalogue of the living Bivalvia of the Eastern Pacific Ocean: Bering Strait to Cape Horn: Canadian Special Publication of Fisheries and Aquatic Sciences 61, $102 \mathrm{p}$.

Bramkamp, R. A., 1935, Stratigraphy and molluscan fauna of the Imperial Formation of San Gregorio Pass, California: Berkeley, Calif., University of California, Ph. D. dissertation, 86 p., plus unnumbered p., $10 \mathrm{pls}$.
Broderip, W. J., 1833, Characters of new species of Mollusca...: Zoological Society of London Proceedings for 1832, p. 4-9.

Carpenter, P. P., 1857, Catalogue of the collection of Mazatlan shells in the British Museum: collected by Frederick Reigen: Washington, England, Oberlin Press, $552 \mathrm{p}$.

1864, Supplementary report on the present state of our knowledge with regard to the Mollusca of the west coast of North America: British Association for the Advancement of Science Report 1863, p. 517-686.

Carson, C. M., 1965, The Rincon Formation, in Western Santa Ynez Mountains, Santa Barbara County, California, Guidebook, 1965: Coast Geological Society Economic Paleontologists Mineralogists, Pacific Section, p. 38-40.

Clark, Alexander, 1931, The cool-water Timms Point Pleistocene horizon at San Pedro, California: San Diego Society of Natural History Transactions, v. 7 , no. 4 , p. $25-42$.

Clark, B. L., 1915, Fauna of the San Pablo Group of middle California: University of California Publications, Department of Geology Bulletin, v. 8, no. 22, p. 385-572, pls. 42-71.

1918, The San Lorenzo Series of middle California: University of California Publications, Department of Geology Bulletin, v. 11, no. 2, p. 45-234, pls. 3-24, 4 text figs.

1929 , Stratigraphy and faunal horizons of the Coast Ranges of California: California, published by author, 132 p., 50 pls. [Xerox available from University Microfilms, Inc., 30 p., 50 pls., Ann Arbor, Michigan.]

Clark, B. L., and Arnold, Ralph, 1923, Fauna of the Sooke Formation, Vancouver Island, with a description of a new coral by T. Wayland Vaughan: University of California, Department of Geological Sciences Bulletin, v. 14, no. 5, p. 123-234, pls. 15-42.

Clark, S. G., 1940, Geology of the Covelo District, Mendocino County, California: University of California, Department of Geological Sciences Bulletin, v. 25, no. 2, p. 119-142, 7 figs.

Conrad, T. A., 1853, Notes on shells with descriptions of new species: Philadelphia Academy of Natural Sciences Proceedings for 1852, v. 6 , no. 6 , p. $199-200$.

1854, Descriptions of new fossil shells of the United States: Philadelphia Academy Natural Sciences Journal, ser. 2, v. 2, no. 4, p. 299-300.

1855 [1856], Descriptions of eighteen new Cretaceous and Tertiary fossils: Philadelphia Academy of Natural Sciences Proceedings, v. 7, p. 267.

$-1857 a$, Descriptions of three new genera; twenty-three new species middle Tertiary fossils from California, and one from Texas: Philadelphia Academy of Natural Sciences Proceedings, v. 8, p. 312-316. [Reprinted in Dall, 1909, p. 173-175.]

1857b, Description of the Tertiary fossils collected on the survey [Williamson's survey], in Reports of explorations and surveys *** railroad $* * *$ from the Mississippi River to the Pacific Ocean: U.S. 33d Congress, 2d Session, Senate Executive Document No. 78 and House of Representatives Executive Document No. 91, v. 6, pt. 2, p. 69-73, pls. 2-5. [Reprinted in Dall, 1909, p. 176-179.]

$-1857 \mathrm{c}$, Report on the paleontology of the Survey [Parke's survey], in Reports of explorations and surveys *** railroad *** from the Mississippi River to the Pacific Ocean: U.S. 33d Congress, 2d Session, Senate Executive Document No. 78 and House of Representatives Executive Document No. 91, v. 7, pt. 2, p. 189-196, pls. 1-10. [Reprinted in Dall, 1909, p. 180-185.]

1857d, Descriptions of the fossil shells, in Williamson, R. S., Report of explorations in California for railroad routes...: U.S. 33d Congress, 2d Session, Senate Executive Document 78 and House of Representatives Executive Document 91, v. 5, pt. 2, appendix 2, p. 317-329, pls. 2-9 [Pacific Railroad Reports].

1857e, Descriptions of Cretaceous and Tertiary fossils, in Emory, W. H., Report of the United States and Mexican boundary 
survey: U.S. 34th Congress, 1st session, Senate Executive Document 108 and House Executive Document 135, v. 1, pt. 2, p. 141-174, pls. 17-19.

Cummings, J. C., Touring, R. M., and Brabb, E. E., 1962, Geology of the northern Santa Cruz Mountains, California, in Bowen, O. E., Jr., ed., Geologic guide to the gas and oil fields of northern California: California Division of Mines and Geology Bulletin 181, p. 179-220.

Dall, W. H., 1900, A new species of Lima: Nautilus, v. 14, no. 2, p. 15-16 1909, The Miocene of Astoria and Coos Bay, Oregon, Pt. I of Contributions to the Tertiary paleontology of the Pacific Coast: U.S. Geological Survey Professional Paper 59, 278 p., 23 pls.

1914, Notes on West American oysters: Nautilus, v. 28, no. 1, p. 1-3.

- 1925, Illustrations of unfigured types of shells in the collection of the United States National Museum: U.S. National Museum Proceedings, v. 66, art. 17, no. 1554, p. 1-41, pls. 1-36.

Darton, N. H., 1921, Geologic reconnaissance in Baja California: Journal of Geology, v. 29, p. 720-748, 22 figs.

Dehlinger, Peter, and Jennings, C. W., 1952, Geology of the southern Ridge Basin, Los Angeles County, California: California Department Natural Resources, Division of Mines Special Report 26, 11 p., includes geologic map.

Deshayes, G. P., 1839, Nouvelles especes de mollusques, provenant des cotes de la Californie, du Mexique, du Kamtschatka et de la Nouvelle-Zelande: Revue zoologique, par la Societe Cuvierienne, v. 2 , p. $356-361$.

Dibblee, T. W., Jr., 1950, Geology of southwestern Santa Barbara County, California; Point Arguello, Lompoc, Point Conception, Los Olivos, and Gaviota quadrangles: California Division of Mines Bulletin 150, $95 \mathrm{p}$.

Dickerson, R. E., 1914, Fauna of the Martinez Eocene of California: University of California Publications, Department of Geology Bulletin, v. 8, no. 6, p. 61-180, pls. 6-18.

Dickinson, W. R., 1966, Table Mountain serpentinite extrusion in California: Geological Society America Bulletin, v. 77, no. 5, p. 451-472.

1969, Miocene stratigraphic sequence on upper Sespe Creek and Pine Mountain [California], in Dickinson, W. R., chm., Society of Economic Paleontologists and Mineralogists, Pacific Coast Section, 1969 Field Trip [Guidebook], upper Sespe Creek: p. 49-55.

Dodge, Henry, 1952, A historical review of the mollusks of Linnaeus; part 1. The classes Loricata and Pelecypoda: American Museum of Natural History Bulletin, v. 100, article 1, p. 1-263.

Doerner, D. P., 1969, Lower Tertiary biostratigraphy of southwestern Santa Cruz Island, in Weaver, D. W., Geology of the northern Channel Islands: American Association Petroleum Geologists and Society Economic Paleontologists and Mineralogists, Pacific Section, Special Publication, 1969

Durham, D. L., 1968, Geology of the Tierra Redonda Mountain and Bradley quadrangles, Monterey and San Luis Obispo Counties, California: U.S. Geological Survey Bulletin 1255, 60 p.

Durham, D. L., and Addicott, W. O., 1965, Pancho Rico Formation, Salinas Valley, California: U.S. Geological Survey Professional Paper 524-A, p. A1-A22, 5 pls.

Durham, D. L., and Yerkes, R. F., 1964, Geology and oil resources of the eastern Puente Hills area, southern California: U. S. Geological Survey Professional Paper 420-B, p. B1-B62.

Durham, J. W., 1950, Megascopic paleontology and marine stratigraphy, in 1940 E. W. Scripps Cruise to the Gulf of California, pt. II: Geological Society of America Memoir 43, p. 1-216, 48 pls.

Eaton, J. E., 1928, Divisions and duration of the Pleistocene in southern California: American Association of Petroleum Geologists Bulletin, v. 12 , no. 5, p. 559-560.

Eaton, J. E., Grant, U. S., 4th, and Allen, H. B., 1941, Miocene of
Caliente Range and environs, California: American Association of Petroleum Geologists Bulletin, v. 25, no. 2, p. 193-262, 9 pls.

Eldridge, G. H., and Arnold, Ralph, 1907, The Santa Clara Valley, Puente Hills, and Los Angeles oil districts, southern California: U.S. Geological Survey Bulletin 309, 266 p., pls. 25-41.

Emerson, W. K., 1956, Pleistocene invertebrates from Punta China, Baja California, Mexico: American Museum of Natural History Bulletin, v. 3, art. 4, p. 319-342, 2 tables.

-1980 . Invertebrate faunules of late Pleistocene age, with zoogeographic implications, from Turtle Bay, Baja Califronia Sur, Mexico: The Nautilus, v. 94, no. 2, p. 67-89, 2 tbls.

Emerson, W. K., and Hertlein, L. G., 1960, Pliocene and Pleistocene invertebrates from Punta Rosalia, Baja California, Mexico: American Museum Novitates, no. 2004, p. 1-8, 3 figs.

Emerson, W. K., and Hertlein, L. G., 1964, Invertebrate megafossils of the Belvedere Expedition to the Gulf of California: San Diego Society of Natural History Transactions, v. 13, no. 17, p. 333-368, 6 figs.

English, W. A., 1914, The Fernando Group near Newhall, California: California University, Department of Geology Bulletin, v. 8, p. 203-218, pl. 23.

Fairbanks, H. W., 1904, San Luis [Quadrangle) California folio 101 of Geologic Atlas of the United States: U. S. Geological Survey, 14 p., 4 maps.

Fitch, J. E., 1953, Common marine bivalves of California: California Department of Fish and Game, Marine Fisheries Branch, Fish Bulletin 90,102 p. 63 figs.

Gabb, W. M., 1864, Description of the Cretaceous fossils: California Geological Survey, Paleontology, v. 1, sec. 4, p. 55-243, pls. 9-32. -1866 , Tertiary invertebrate fossils: California Geological Survey, Paleontology, v. 2, sec. 1-3, pt. 1, p. 1-38, pls. 1-13.

-1869 , Tertiary invertebrate fossils: California Geological Survey, Paleontology, v. 2, Cretaceous and Tertiary fossils, sec. 1, 2, pt. 2, p. 1-254, 36 pls.

Givens, C. R., 1974, Eocene molluscan biostratigraphy of the Pine Mountain area, Ventura County, California: University of California Publications in Geological Sciences, v. 109, 107 p., 11 pls., 1 table, 1 map.

Givens, C. R., and Kennedy, M. P., 1976, Middle Eocene mollusks from northern San Diego County, California: Journal of Paleontology, v. 50 , no. 5 , p. $954-975$.

Glen, William, 1959, Pliocene and lower Pleistocene of the western part of the San Francisco Peninsula: California University Publications in Geological Sciences, v. 36, no. 2, p. 147-198, pls. 15-17, 5 text figs.

Grant, U. S., 4th, and Gale, H. R., 1931, Catalogue of the marine Pliocene and Pleistocene Mollusca of California and adjacent regions: San Diego Society of Natural History Memoir, v. 1, 1036 p., 32 pls., 15 figs., 3 tables.

Guppy, R. J. L., 1867, On the Tertiary fossils of the West-Indies, with special reference to the classification of the Kainoazoic rocks of Trinidad: Science Association Trinidad Proceedings, v. 1, pt. 3, p. 145- 176; reprint, Bulletins of American Paleontology, v. 8, no. 35, p. 24-55, 1921.

Hall, C. A., 1960, Displaced Miocene molluscan provinces along the San Andreas fault, California: University of California Publications in Geological Sciences, v. 34, no. 6, p. 281-308.

Hall, E. B., and Ambrose, A. W., 1916, Descriptions of new species from the Cretaceous and Tertiary of the Tesla, Pleasanton, San Jose, and Mt. Hamilton quadrangles, California: Nautilus, v. 30, no. 6 , p. $68-71$, no. 7 , p. $77-82$.

Hanley, S. C. T., 1842-56, An illustrated and descriptive catalogue of recent bivalve shells: London, 8 v., p. i-xviii, 1-392, suppl. pls. 9-24, p. $1-24$.

Hanna, G D., 1926a, Paleontology of Coyote Mountain, Imperial 
County, California: California Academy of Sciences Proceedings, ser. 4 , v. 14 , no. 18 , p. $427-503$, text fig. 1, pls. 20-29.

1926b, Expedition to the Revillagigedo Islands, Mexico, in 1925:

California Academy of Sciences Proceedings, v. 15, no. 1, p. 1-113.

1943, Characteristic fossils of California: California Division of Mines Bulletin 118, p. 165-182, figs. 62-65.

Hanna, G D., and Hertlein, L. G., 1927, Notes on Ostrea californica Marcou: Nautilus, v. 41, no. 2, p. 45-46.

Hanna, M. A., 1926, Geology of the La Jolla Quadrangle, California: University of California, Department of Geological Sciences Bulletin, v. 16, no. 7, p. 187-246.

1927, An Eocene invertebrate fauna from the La Jolla quadrangle, California: University of California Publications, Department of Geological Sciences Bulletin, v. 16, no. 8, p. 247-398, pls. 24-57.

1928, Preliminary report on the paleontology of the Channel Islands, California: Journal of Paleontology, v. 2, no. 2, p. 142-157, pls. 22-25.

Harry, H. W., 1981, Nominal species of living oysters proposed during the last fifty years: The Veliger, v. 24, no. 1, p. 39-45.

1983, Homology of the five types of marginal denticles (chomata) of living oysters, (Gryphaeidae and Ostreidae): American Malacological Bulletin 1, p. 90.

Harry, H. W., and Dockery, D. T., III, 1983, Notes on the lower Oligocene oysters of Mississippi: Mississippi Geology, Department of Natural Resources, v. 4, no. 2, p. 7-14, 6 figs.

Heilprin, Angelo, 1884, North American Tertiary Ostreidae: U.S. Geological Survey 4th Annual Report, p. 309-316, pls. 62-82.

Hertlein, L. G., 1928, Preliminary report on the paleontology of the Channel Islands, California: Journal Paleontology, v. 2, no. 2, p. 142-157, pls. 22-25.

1929, Three new specific names for West American fossil Mollusca: Journal of Paleontology, v. 3, no. 3, p. 295-297.

1933, A new gryphaeoid oyster from the Eocene of California: San Diego Society of Natural History Transactions, v. 7, no. 222, p. 277-280, pl. 18, figs. 5,6 .

1934a, Pleistocene mollusks from the Tres Marias Islands, Cedros Island, and San Ignacio Lagoon, Mexico: Southern California Academy of Sciences Bulletin, v. 33, pt. 2, p. 59-73, pl. 21.

1934b, New oysters and a new Pecten from the Tertiary of California: Southern California Academy of Sciences Bulletin, v. 33 , pt. 1, p. 1-5, pls. 1, 2 .

-1951a, Invertebrate fossils and fossil localities in the San Francisco Bay area, in Geologic Guidebook of the San Francisco Bay Counties [California]: California Division Mines Bulletin 154, p. 187-192, figs. 1-2.

1951b, Descriptions of two new species of marine pelecypods from west Mexico: Southern California Academy of Sciences Bulletin, v. 50, p. 68-75, pls. 24-26.

1952, Description of a new pelecypod of the genus Lima from deep water off Central California: California Academy of Sciences Proceedings, ser. 4, v. 27, no. 2, p. 377-381, pl. 20, figs. 12, 13.

-1957 , Pliocene and Pleistocene fossils from the southern portion of the Gulf of California [Mexico]: Southern California Academy of Sciences Bulletin, v. 56, pt. 2, p. 57-75, pl. 13.

-1959 , Notes on California oysters: The Veliger, v. 2, no. 1, p. 5-10, pl. 2.

1966, Pliocene fossils from Rancho El Refugio, Baja California, and Cerralvo Island, Mexico: California Academy of Sciences Proceedings, ser. 4, v. 30 , no. 14, p. 265-284, figs. 1-17.

1968, Three late Cenozoic molluscan faunules from Baja California, with a note on diatomite from west of San Felipe: California Academy of Sciences Proceedings, series 4, v. 30, no. 19, p. 401-405.

Hertlein, L. G., and Allison, E. C., 1959, Pliocene marine deposits in northwest Baja California, Mexico, with the description of a new species of Acanthina (Gastropoda): Southern California Academy of Sciences Bulletin, v. 58, pt. 1, p. 17-26, 8 pls.

Hertlein, L. G., and Emerson, W. K., 1959, Pliocene and Pleistocene megafossils from the Tres Marias Islands, [Pt.] 5 , in Results of the Puritan-American Museum of Natural History Expedition to Western Mexico: American Museum Novitates, no. 1940, 15 p., 5 figs.

Hertlein, L. G., and Grant, U. S., 4th, 1972, The geology and paleontology of the marine Pliocene of San Diego, California (Paleontology: Pelecypoda): San Diego Society of Natural History Memoir 2, pt. 2B, 409 p., pls. 28-57.

Hertlein, L. G., and Jordan, E. K., 1927, Paleontology of the Miocene of Lower California: California Academy of Sciences Proceedings, ser. 4, v. 16, no. 19 , p. 605-647, pls. 17-21.

Hertlein, L. G., and Strong, A. M., 1940-1951, Eastern Pacific expeditions of the New York Zoological Society. Mollusks from the west coast of Mexico and Central America: pts. I-X; Zoologica [New York], pt. 1, v. 25, p. 369-430, pls. 1-2 (1940); pt. 2, v. 28, p. 149-168, pl.11(1943); pt. 3,v. 31, p. 53-76, pl.1(1946); pt.4,v. 31, p. 93-120, pl. 1(1946); pt. 5,v. 31, p. 129-150, pl.1(1947); pt. 6,v. 33, p. 163-198, pls 1-2 (1958); pt. 7, v. 34, p. 63-97, pl. 1 (1949); pt. 8, v. 34, p. 239-258, pl. 1 (1949); pt. 9 , v. 35 , p. $217-252$, pls. $1-2(1950)$; pt. 10 , v. 36 , p. 67-120, pls. 1-11(1951).

1955, Marine mollusks collected during the "Askoy" expedition to Panama, Colombia, and Ecuador in 1941: American Museum of Natural History Bulletin, v. 107, art. 2, p. 159-318, 3 pls.

Hill, M. L., Carlson, A., and Dibblee, T. W., Jr., 1958, Stratigraphy of Cuyama Valley-Caliente Range area, California: American Association of Petroleum Geologists Bulletin, v. 42, no. 12, p. 2973-3000.

Hoots, H. W., 1931, Geology of the eastern part of the Santa Monica Mountains, Los Angeles County, California: U.S. Geological Survey Professional Paper 165-C, p. 83-134, pls. 18-33.

Hopkins, A. E., 1936, Spawning, larval development and setting of the Olympic oyster, Ostrea lurida: U.S. Bureau of Fisheries Bulletin, v. 48, p. $439-503$.

Howard, P. J., 1935, Report on Buena Vista Hills, a portion of the Midway-Sunset oil field [California]: California Oil Fields, v. 20, no. 4 , p. $5-22,7$ pls.

Huey, A. S., 1948, Geology of the Tesla Quadrangle, California: California Division of Mines and Geology Bulletin 140, $75 \mathrm{p}$.

Jackson, R. T., 1890, Phylogeny of the Pelecypoda, the Aviculinae and their allies: Boston Society of Natural History Memoirs, v. 4, no. 8,400 p., $30 \mathrm{pls}$

Jordan, E. K., 1936, The Pleistocene fauna of Magdalena Bay, Lower California: Stanford University, Department of Geology Contributions, v. 1, no. 4, p. 107-173.

Jordan, E. K., and Hertlein, L. G., 1926a, A Pliocene fauna from Maria Madre Island, in Expedition to the Revillagigedo Islands, Mexico, in 1925: California Academy of Sciences Proceedings, ser. 4 , v. 15 , no. 4 , p. $209-217$

$1926 \mathrm{~b}$, Contribution to the geology and paleontology of the Tertiary of Cedros Island and adjacent parts of Lower California: California Academy of Sciences Proceedings, series 4, v. 15, no. 14, p. 409-464, pls. 27-34.

Kanakoff, G. P., and Emerson, W. K., 1959, Late Pleistocene invertebrates of the Newport Bay area, California: Los Angeles County Museum Contributions in Science No. 31, 47 p., 5 figs.

Keen, A. M., 1971, Sea shells of tropical west America [2d ed.]: Stanford, Calif., Stanford University Press, 1064 p., 3305 figs.

Keen, A. M., and Bentson, Herdis, 1944, Check list of California Tertiary marine Mollusca: Geological Society of America Special Paper 56, 280 p., 4 figs., 2 tables.

Kennedy, G. L., 1975, Paleontologic record of areas adjacent to the 
Los Angeles and Long Beach Harbors, Los Angeles County, California: Allan Hancock Expedition, Marine Studies of San Pedro Bay, California, pt. 9. Paleontology, p. 1-119.

Kern, J. P., 1973, Early Pliocene marine climate and environment of the eastern Ventura basin, southern California: University of California Publications in Geological Sciences, v. 96,117 p., 27 figs.

Kern, J. P., Stump, T. E., and Dowlen, R. J., 1971, An upper Pleistocene marine fauna from Mission Bay, San Diego, California: San Diego Society of Natural History Transactions, v. 16, no. 15, p. 329-338.

Kern, J. P., and Wicander, E. R., 1974, Origin of a bathymetrically displaced marine invertebrate fauna in the upper part of the Capistrano Formation (lower Pliocene), southern California: Journal of Paleontology, v. 48, no. 3, p. 495-505, 4 text figs.

Kew, W. S. W., 1924, Geology and oil resources of a part of Los Angeles and Ventura Counties, California: U.S. Geological Survey Bulletin 753, $202 \mathrm{p}$.

Linne, Carl, 1758, Systema naturae per regna tria naturae $*: *:$ Edition 10, v. 1, 824 p.

1767, Systema naturae per regna tria naturae $* *: k$ Editio duodecima, reformata: Stockholm, v. 1, pt. 2, p. 533-1327.

Loel, Wayne, and Corey, W. H., 1932, Paleontology, pt. I of The Vaqueros Formation, lower Miocene of California: University of California, Department of Geological Sciences Bulletin, v. 22, no. 3, p. 31-410, pls. 4-65, 2 maps.

Martin, Bruce, 1916. The Pliocene of niddle and northern California: University of California, Department of Geology Bulletin. v. 9, no. 15, p. $215-259,3$ tables.

McFall, C. C., 1968, Reconnaissance geology of the Concepcion Bay area, Baja California, Mexico: Stanford University Publications, Geological Sciences, v. 10, no. 5, 25 p.

McLean, James, 1978, Marine shells of southern California: Los Angeles County Museum of Natural History, Science Series 24, (rev. ed.), 104 p., 54 figs.

Mina, Federico, 1956, Geologia de la parte sur de la Peninsula de Baja California: International Geological Congress, 20th, Mexico City, Mexico, 1956, Excursion A-7, 79 p., 5 maps, 1 table.

1957, Bosquejo geologico del Territorio Sur de la Baja California: Asociacion Mexicana Geologos Petroleros Boletin, v. 9. p. 139-269.

Minch, J. C., Gastil, Gordon, Fink, William, Robinson, John, and James, A. H., 1976, Geology of the Vizcaino Peninsula, in Howell, D. G., ed., Aspects of the geologic history of the California continental borderland: American Association of Petroleum Geologists, Pacific Section, Misc. Pub. 24, p. 136-195, 5 text figs.

Moore, E. J., 1977, A uniquely sculptured middle Miocene pelecypod of the genus Lima: The Veliger, v. 19, no. 3, p. 277-278, 10 figs.

Moore, R. C., 1969, Treatise on invertebrate paleontology: Geological Society of America and University of Kansas, pt. N, Mollusca, v. 1-3, 1224 p., illus.

Nelson, R. N., 1925, A contribution to the paleontology of the Martinez Eocene of California: University of California, Department of Geological Sciences Bulletin, v. 15, no. 11, p. 397-466, pls. 49-61.

Nomland, J. O., 1917, Fauna of the Santa Margarita beds in the north Coalinga region of California: University of California, Department of Geology Bulletin, v. 10, no. 18, p. 293-326, pls. 14-20.

Oakeshott, G. B., 1958, Geology and mineral deposits of San Fernando quadrangle, Los Angeles County, California: California Division of Mines Bulletin 172, $147 \mathrm{p}$.

Ogle, B. A. 1953, Geology of the Eel River Valley area, Humboldt County, California: California Division of Mines Bulletin, v. 164, $128 \mathrm{p}$.

Oldroyd, I. S., 1924 [1925], The marine shells of the West Coast of
North America: Stanford University Publications, Geological Sciences, v. 1, no. 1, 247 p., $57 \mathrm{pls}$.

Olsson, A. A., 1961, Mollusks of the tropical eastern Pacific: Ithaca, New York, Paleontological Research Institute, 547 p., 86 pls.

1964, Neogene mollusks from northwestern Ecuador: Ithaca, New York, Paleontological Research Institute, 256 p., 38 pls. Orbigny, Alcide d', 1834-47. Voyage dans l'Amerique Meridionale, **** Mollusques: Paris, v. 5, pt. 3, 758 p.; atlas 85 pls.

Oyama, Katura, 1952, Preliminary notes on the ostreid phylogeny: Annotationes Zoologicae Japonenses, v. 25, nos. 1-2, p. 337-342, University of Tokyo, Zoological Institute, Zoological Society of Japan.

Packard, E. L., 1923, An aberrant oyster from the Oregon Eocene: University of Oregon Publication, v. 2, no. 4, 6 p., 4 pls.

Palmer, K. V. W.. 1938, Neocene Spondyli from the southern United States and tropical America: Paleontographica Americana, v. 2, no. 8 , p. $147-162,3$ pls.

-1958, Type specimens of marine Mollusca described by P. P. Carpenter from the West Coast: Geological Society of America Memoir 76, 376 p., 35 pls., 2 tables.

Park, W. H., Weddle, J. R., and Barnes, J. A., 1963 [1964], Main, Coffee Canyon, and Pyramid areas of Round Mountain oil field [California]: California Oil Fields, v. 49, no. 2, p. 23-37.

Pleshakov, I. B., 1939, Tertiary deposits of the Utkholoksk Region of west Kamchatka: Nentianoi Geologo Razvedochny Institut Trudy, series A, issue 123

Poli, J. X., 1795. Testacea utriusque Siciliae eorumque historia et anatome: Parma, Folio, v. 2, 344 p., pls. 19-39.

Purchon, R. D., 1977, The biology of the Mollusca: v. 57 of International Series of monographs in pure and applied biology; Zoology, New York, Pergamon Press, 560 p., 185 figs., 21 tables.

Remond, Auguste, 1863. Description of two new species of bivalve shells from the Tertiaries of Contra Costa County: California Academy of Sciences Proceedings, v. 3, p. 13.

Rochebrune, A.-T. de, 1895, Diagnoses de mollusques nouveaux, provenant du voyage de M. Diguet en Basse-Californie: Musee National d' Histoire Naturelle de Paris Bulletin, v. 1, p. 239-243.

Rodda, P. U., 1957, Paleontology and stratigraphy of some marine Pleistocene deposits in northwest Los Angeles basin, California: American Association of Petroleum Geologists Bulletin, v. 41, no. 11, p. 2475-2492.

Sakamoto, Kenji, 1973, Techniques for photographing modern mollusks: The Veliger, v. 16, no. 2, p. 140-142, 1 pl.

Smith, A. G., and Gordon, Mackenzie, Jr., 1948, The marine mollusks and brachiopods of Monterey Bay, California: California Academy of Sciences Proceedings, ser. 4, v. 26, no. 8, p. 147-245, pls. 3, 4, 4 figs.

Smith, J. P., 1912, Geologic range of Miocene invertebrate fossils of California: California Academy of Sciences Proceedings, ser. 4, v. 3 , no. 8, p. 161-182.

Smith, J. T., 1984, Miocene and Pliocene marine mollusks and preliminary correlations, Vizcaino Peninsula to Arroya la Purisima, northwestern Baja California Sur, Mexico, in Frizzell, Virgil A., ed., Geology of the Baja California Peninsula: Society of Economic Paleontologists and Mineralogists, Pacific Section, v. 39, San Diego, Calif., p. 197-215, 8 pls.

Soper, E. K., and Grant, U. S., 4th, 1932, Geology and paleontology of a portion of Los Angeles, California: Geological Society of America Bulletin, v. 43, no. 12, p. 1041-1068, 7 figs.

Squires, R. L., 1977, Middle Eocene molluscan assemblage and stratigraphy, lower Piru Creek, Transverse Ranges, California: California Division of Mines Special Report 129, p. 81-86.

Squires, R. L., and Fritsche, A. E., 1978, Miocene macrofauna along 
Sespe Creek, Ventura County, California, in Fritsche, A. E., ed., Depositional environments of Tertiary rocks along Sespe Creek, Ventura County, California: Society of Economic Paleontologists and Mineralogists, Pacific Section, Los Angeles, Calif., Pacific Coast Paleogeography Field Guide 3, p. 6-26

Squires, R. L., and White, D. R., 1983, Common megafossils of the lower Saugus Formation, northern Simi Valley area, California: in Squires, R. L., and Filewicz, M. V., eds., Cenozoic geology of the Simi Valley area, southern California: Society of Economic Paleontologists and Mineralogists, Pacific Section, Fall Field trip volume and guidebook, p. 221-224.

Stanton, R. J., Jr., 1966, Megafauna of the upper Miocene Castaic Formation, Los Angeles County, California: Journal of Paleontology, v. 40 , no. 1, p. $21-40,3$ pls.

Stanton, T. W., 1896, The faunal relations of the Eocene and upper Cretaceous on the Pacific coast: U.S. Geological Survey 17th Annual Report, pt. 1, p. 1005-1060, pls. 63-67.

Stenzel, H. B., 1949, Successional speciation in paleontology: The case of the oysters in the sellaeformis stock: Evolution, v. 3, p. 34-50, 8 figs.

-1971, Oysters, in Moore, R. C., Treatise on invertebrate paleontology: Geological Society of America and University of Kansas, pt. N, Mollusca 6, v. 3, 1224 p., 153 figs.

Stewart, R. B., 1930, Gabb's California Cretaceous and Tertiary type Lamellibranchs: Academy of Natural Sciences, Philadelphia, Special Publication 3, 314 p., 17 pls.

1946, Geology of Reef Ridge, Coalinga district, California: U.S. Geological Survey Professional Paper 205-C, p. 81-115, pls. 9-17.

Stump, T. E., 1979, The evolutionary biogeography of west Mexican Pectinidae (Mollusca: Bivalvia): Davis, Calif., University of California, Doctoral dissertation, 520 p., 19 pls.

Trask, P. D., 1922, The Briones Formation of middle California: University of California, Department of Geological Sciences Bulletin, v. 13 , no. 5 , p. $133-174$, pls. $1-8$.

Turner, F. E., 1938, Stratigraphy and mollusca of the Eocene of western Oregon: Geological Society of America Special Paper 10, 130 p., 22 pls., 8 tables.

Valentine, J. W., 1956, Upper Pleistocene Mollusca from Potrero Canyon, Pacific Palisades, California: San Diego Society of Natural History Transactions, v. 12, no. 10, p. 181-205, pl. 13, 1 map.

_- 1957, Late Pleistocene faunas from the northwestern coast of Baja California, Mexico: San Diego Society of Natural History Transactions, v. 12 , no. 16 , p. 289-308, figs. 1-6.

-1960 , Habitats and sources of Pleistocene mollusks at Torrey Pines Park, California: Ecology, v. 41, no. 1, p. 161-165

Valentine, J. W., and Rowland, R. R., 1969, Pleistocene invertebrates from northwestern Baja California Del Norte, Mexico: California Academy of Sciences Proceedings, 4th ser., v. 36, no. 17, p. 511-530, 5 figs., 4 tables.

VanderHoof, V. L., 1937, A study of the Miocene sirenian Desmostylus: University of California, Department Geological Sciences Bulletin, v. 24 , no. 8 , p. $169-262,25$ pls., 2 figs.

Vedder, J. G., 1970, Geologic map of the Wells Ranch and Elkhorn Hills Quadrangles, San Luis Obispo and Kern Counties, California, showing juxtaposed Cenozoic rocks along the San Andreas fault: U.S. Geological Survey Miscellaneous Geologic Investigations Map I-585, 2 sheets, scale 1:24,000, sections.

1972, Review of stratigraphic names and megafaunal correlation of Pliocene Rocks along the southeast margin of the Los Angeles basin, California, in Stinemeyer, E. H., ed., Pacific Coast Miocene Biostratigraphic Symposium: Society of Economic Paleontologists and Mineralogists, Pacific Section, 47th, Bakersfield, Calif., Proceedings, 1972, p. 158-172.
1973, Geologic framework and correlation of Miocene rocks in the Caliente Range, in Sedimentary facies changes in Tertiary rocks-California Transverse and southern Coast Ranges: American Association of Petroleum Geologists, Society of Economic Paleontologists and Mineralogists, and Society of Economic Geologists, Pacific Section, 26th, Anaheim, Calif., 1973, p. 42-53, 9 figs.

Vedder, J. G., and Moore, E. J., 1976, Paleoenvironmental implications of fossiliferous Miocene and Pliocene strata on San Clemente Island, California, in Howell, D. G., ed., Aspects of the geologic history of the California continental borderland: American Association of Petroleum Geologists, Pacific Section, Misc. Pub. 24, p. 107-127, 4 pls., 1 table, 9 figs.

Vedder, J. G., and Norris, R. M., 1963, Geology of San Nicolas Island, California: U.S. Geological Survey Professional Paper 369, 65 p.

Vokes, H. E., 1935, Notes on the variation and synonymy of Ostrea idriaensis Gabb: University of California, Publications Department of Geological Sciences Bulletin, v. 23, no. 9, p. 291-304, pls. $22-24$

1939, Molluscan faunas of the Domengine and Arroyo Hondo Formations of the California Eocene: New York Academy of Sciences Annals, v. 38, p. 1-246, pls. 1-22.

1963, Studies on Tertiary and recent giant Limidae: Tulane Studies in Geology, v. 1, no. 2, p. 73-92, 2 pls.

Vyalov [Vialov], O. S., 1936, Sur la classification des huitres: Akademiya Nauk S.S.S.R. Doklady, n.s., v. 4(13), no. 1(105), p. 17-20.

Waller, T. R., 1978, Morphology, morphoclines and a new classification of the Pteriomorpha (Mollusca: Bivalvia): Philosophical Transactions of the Royal Society of London, Bulletin 284, p. 345-365, 2 figs.

Waring, C. A., 1914, Eocene horizons of California: Journal of Geology, v. 22 , no. 8 , p. $782-785$

-1917, Stratigraphic and faunal relations of the Martinez to the Chico and Tejon of southern California: California Academy of Sciences Proceedings, ser. 4, v. 7, no. 4, p. 41-124, pls. 7-16.

Waterfall, L. N., 1929, A contribution to the paleontology of the Fernando Group, Ventura County, California: University of California, Department of Geological Sciences Bulletin, v. 18, no. 3, p. $71-92$, pls. 5,6 .

Weaver, C. E., 1905, Contribution to the paleontology of the Martinez Group: University of California, Department of Geology Bulletin, v. 4, no. 5, p. 101-123.

1912, A preliminary report on the Tertiary paleontology of western Washington: Washington Geological Survey Bulletin 15, p. 1-80, pls. 1-15.

1942, Paleontology of the marine Tertiary formations of Oregon and Washington: [Seattle], University of Washington Publications in Geology, v. 5, pt. 1, 268 p., pt. 3, p. 563-790, 104 pls.

-1949 , Geology of the Coast Ranges immediately north of the San Francisco Bay region, California: Geological Society of America Memoir 35, 242 p.

1953, Eocene and Paleocene deposits at Martinez, California: [Seattle], University of Washington, Publications in Geology, v. 7, 102 p., pls. 1,2

Weaver, C. E., and Palmer, K. V. W., 1922, Fauna from the Eocene of Washington: [Seattle], University of Washington, Publications in Geology, v. 1, no. 3, p. 1-56, pls. 8-12.

Weaver, D. W., and Doerner, D. P., 1969, Mid-Tertiary stratigraphy, San Miguel Island, in Weaver, D. W., Geology of the northern Channel Islands: American Association of Petroleum Geologists and Society of Economic Paleontologists and Mineralogists, Pacific Section, Special Publication, p. 80-84. 
Weaver, D. W., and Kleinpell, R. M., 1963, Mollusca from the Turritella variata Zone, Pt. 2 in Oligocene biostratigraphy of the Santa Barbara Embayment, California: University of California Publications in Geological Sciences, v. 43, p. 81-161, pls. 18-38; pt. 3, p. 165-250.

Weaver, D. W., and Meyer, G. L., 1969, Stratigraphy of northeastern Santa Cruz Island [California], in Weaver, D. W., ed., Geology of the northern Channel Islands: American Association of Petroleum Geologists and Society of Economic Paleontologists and Mineralogists, Pacific Section, Special Publication, p. 95-104.

Wiedey, L. W., 1928, Notes on the Vaqueros and Temblor Formations of the California Miocene with descriptions of new species: San Diego Society of Natural History Transactions, v. 5, no. 10, p. 95-182, pls. 9-21.

-1929 a, Some previously unpublished figures of type mollusks from California: Nautilus, v. 43, no. 1, p. 21-26, pls. 1-3.

1929b, New Miocene mollusks from California: Journal of Paleontology, v. 3 , no. 3 , p. 280-289, pls. 31-33.

Wilkinson, E. R., 1963, Hollister Field [California]: California Oil Fields, v. 49 , no. 1 , p. $27-37$.

Willett, George, 1946, Additional notes on the Pliocene molluscan fauna of Los Angeles city [California]: Southern California Academy of Sciences Bulletin, v. 45, pt. 1, p. 28-32.

Wilson, I. F., 1944, Geology of the San Benito quadrangle, California: California Journal of Mines and Geology, v. 39, no. 2, p. 183-270.

1948, Buried topography, initial structures, and sedimentation in Santa Rosalia area, Baja California, Mexico: American Association of Petroleum Geologists Bulletin, v. 32, no. 9, p. 1762-1807, 3 tbls.

Wilson, I. F., and Rocha, V. S., 1955, Geology and mineral deposits of the Boleo Copper District, Baja California, Mexico: U.S. Geo- logical Survey Professional Paper 273, $134 \mathrm{p}$.

Winterer, E. L., and Durham, D. L., 1958, Geologic map of a part of the Ventura Basin, Los Angeles County, California: U.S. Geological Survey Oil and Gas Investigations Map OM-196, scale 1:24,000.

Woodring, W. P., 1925, Miocene mollusks from Bowden, Jamaica; pelecypods and scaphopods: Carnegie Institute of Washington Publication 366,222 p., 28 pls.

-1931, Age of the orbitoid-bearing Eocene limestone and Turritella variata zone of the western Santa Ynez Range, California: San Diego Natural History Museum Transactions, v. 6, no. 25, p. 371-387.

1938, Lower Pliocene mollusks and echinoids from the Los Angeles basin, California and their inferred environment: U.S. Geological Survey Professional Paper 190, 67 p., 9 pls.

1982, Geology and paleontology of Canal Zone and adjoining parts of Panama; description of Tertiary mollusks (Pelecypods: Propeamussiidae to Cuspidariidae) $* * *$ U.S. Geological Survey Professional Paper 306-F, p. 541-759, pls. 83-125, incl. geologic map.

Woodring, W. P., Bramlette, M. N., and Kew, W. S. W., 1946, Geology and paleontology of Palos Verdes Hills, California: U.S. Geological Survey Professional Paper 207, 145 p., 37 pls.

Woodring, W. P., and Bramlette, M. N., 1950, Geology and paleontology of the Santa Maria District, California: U.S. Geological Survey Professional Paper 222, 185 p., 23 pls., 9 figs.

Woodring, W. P., Stewart, Ralph, and Richards, R. W., 1940 [1941], Geology of the Kettleman Hills oil field, California: U.S. Geological Survey Professional Paper 195, 170 p., 57 pls., 15 figs.

Zinsmeister, W. J., 1983, New late Paleocene molluscs from the Simi Hills, Ventura County, California: Journal of Paleontology, v. 57, no. 6 , p. 1282-1303, 4 figs. 


\section{INDEX}

\section{A}

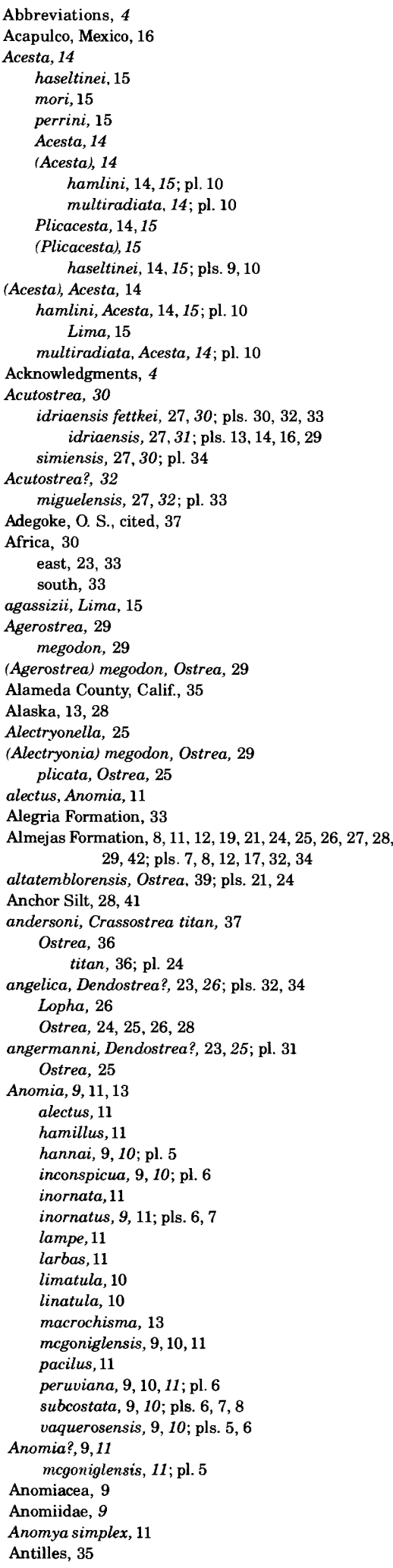

[Italic page numbers indicate major references]

appressa-Continued

Ostrea, 33

Striostrea?, 33; pls. 12, 16

Argentina, 28

Arnold, Ralph, cited, 34

arnoldi, Ostrea, 39; pls. 19, 20

ashleyi, Crassostrea?, 36, 38, 39; pls. 19, 20, 21, 22, 24 Ostrea, 38, 39

Asia, 15, 27

Astarte compressa, 28

Astrodapsis, 41

gregerseni, 41

tumidus, 41

Atlantic, eastern, 27, 28 western, 27, 28, 32

atwoodii, Ostrea, 28 Ostrea (Ostrea), 27, 28; pl. 30

auaua, Lima, 16

Australia, 13, 17

Avenal Formation, 32

Avenal Sandstone, 7, 18, 31, 41

aviculiformis, Gryphaeostrea, 18; pl. 19

Ostrea, 18

\section{B}

Bahia de los Angeles, 23, 26

Bahia Kino, 38

Bahia Magdalena, 8

Baja California, 33

Baja California Norte, 13, 15, 16, 24, 28, 29

Baja California Sur, 6, 8, 11, 12, 13, 19, 21, 22, 23, 24, 25 ,

Bay of Panama, 8 $26,27,29,32,34,38,40$

Bay Point Formation, 28, 29, 41

Beechers Bay Member, Monterey Formation, 34, 41

Boleo Formation, 19, 26, 42

Borneo, 35

bostrychites, Spondylus, 6, 8; pls. 2, 3, 9

bourgeoisii, Crassostrea, 37, 40

Ostrea, 32, 34, 35, 36, 39

Striostrea? bourgeoisii, 33, 34, 37; pls. 25, 26 bourgeoisii, Striostrea?, 33, 34, 37; pls. 25, 26 perrini, Striostrea?, 33, 35, 37; pls. 26, 27

Branch Canyon Sandstone, 35, 36, 37, 39, 40, 41; pls. 21, $24,27,28,29$

Briones Formation, 35; pls. 26, 27

Briones Sandstone, 34

San Pablo Group, 35, 41

buwaldana, Ostrea, 30; pl. 30

calcifer, Spondylus, 6, 8; pl. 4

Caliente Formation, pls. 21, 24

California $13,14,15,17,22$

middle, $7,10,11,12,13,15,17,18,19,22,26,28,30$ $31,35,37,38,39,40$

northern, 5, 15, 30

southern $7,8,10,11,12,13,14,15,16,17,19,20,21$, $22,25,26,28,29,30,31,32,33,34,35$, $37,38,39,40$

californica, Crassostrea, 40

Ostrea, 37, 38

Placunanomia, 11, 12; pl. 6

osunai, Crassostrea?, 36,$40 ; \mathrm{pl} .27$

Ostrea, 40

Canada del Pozo, Calif., 31

Canada Formation, 31, 32, 41; pl. 29

Cantil Costero Formation, 25, 26, 42

Capistrano Formation, 15, 26, 41

Careaga Sandstone, 13,41

Cebada Member, 19, 4

carlosensis, Spondylus, 6, 7; pl. 1

Carlotta Formation, 28, 29, 41

Carmen Formation, 19, 23, 25, 26, 27, 29, 42

Carrizo Creek, Calif., 10, 26

Carrizo Creek beds, Calif., 10
Castaic Formation, 26, 35, 37, 41

Cebada Member, Careaga Sandstone, 19, 41

Cedros Island, 24

Central America, 11, 33

cepio, Placunanomia, 13 Pododesmus, 13 (Monia), 13

cerrosensis, Ostrea, 29, 30; pls. 32, 34

Ostrea megodon, 29

Chile, 14, 38

chilensis, Ostrea, 34, 37, 38; pl. 24

Chinzei, Kiyotaka, cited, 30

Cierbo Formation, 40, 41; pls. 25, 26

Cierbo Sandstone, 35 San Pablo Group, 41 cierboensis, Crassostrea, 37

Ostrea, 35, 36, 39, 40, 41; pls. 25, 26

Clark, S. G., cited, 33, 34

clarki, Lima, 16

Limaria (Limaria), 14, 16; pl. 10

claytonensis, Lima, 16, 17

Limea? (Isolimea?), 14,17; pl. 10

cliffensis, Spondylus, 6, 7; pl. 2

Coalinga, Calif., $7,18,39$

cochlear, Neopycnodonte?, 23; pl. 32 Ostrea, 23

Coldwater Sandstone, 32, 33, 41

Coldwater Sandstone Member, Tejon Formation, 41

Colorado Desert, 10, 21

columbiana, Ostrea, 31

columbiensis, Crassostrea, 36, 37; pls. 24, 26, 28 Ostrea,37, 38 (Crassostrea), 37

Comondu Formation, 21, 42

compressa, Astarte, 28

conchaphila, Ostrea, 28 Ostreola, 27, 28; pl. 30 palmula, Ostrea, 32

Contra Costa County, Calif., 10, 15, 17

Corral Hollow, Alameda County, Calif., 9

corrugata, Ostrea, 39 Ostrea titan, 20, 39

corteziensis, Crassostrea, 37, 38

Ostrea, 37,$38 ;$ pls. 26,28

Cowlitz County, Wash., 30, 31

Cowlitz Formation, 30, 31, 42; pl. 33

Coyote Mountain, 2

Cozy Dell Shale, 7, 4

Cozy Dell Shale Member, Tejon Formation, 41

crandalli, Ostrea, 30; pl. 32

crassisquama, Spondylus, 8; pl. 3

Crassostrea, 30, 32, 33, 35, 37, 40

appressa, 34

bourgeoisii, 37, 40

californica, 40

cierboensis, 37

columbiensis, 36,37 ; pls. $24,26,28$

corteziensis, 37, 38

eldridgei ynezana, 19

gigas, 35

ligminuta, 37

sookensis, 19

titan, $34,35,36,37,38$; pls. $23,24,27,28,29$ andersoni, 37 prior, 37

titan, 33, 35

vaquerosensis, 38

virginica, 33,35

Crassostrea?, 36, 38

ashleyi, 36, 38, 39; pls. 19, 20, 21, 22, 24

californica osunai, 36,$40 ;$ pl. 27

englekyi, 36,38 ; pls. 20,22 eucorrugata, $36,39,40 ;$ pls. $25,26,27$ vaquerosensis, 36,38 ; pls. 21,25

(Crassostrea) columbiensis, Ostrea, 37 titan, Ostrea, 35

Crassostreinae, 30 
Crenostrea, 22

(Crenostrea?, Pycnodonte?, 22

eldridgeı, Pycnodonte?, 18,22; pl. 2

stewarti, Pycnodonte!, 18, 22; pl. 19

cumingt, Placunanomia, 12

t'umingtana, Ostrea, 23, 26; pls. 32,34

cumingit, Placunanomia, 12

Cuyama Valley. Calif., 37

Cypraea, 28

Dall, W. H , cited, 33

Delmar Formation, 11, 30, 31, 32; pls. 5,32 La Jolla Group, 41

Dendostrea, 25, 27

Dendostrea?, 23, 25, 27

angelıca, 23, 26; pls. 32,34

angermanni, 23, 25: pl. 31

vespertına, $21,23,25,26,32$; pis. $11,12,13,14,15,16$ denselamellosa, Ostrea, 27

Desmostylus tooth. 34

Domengine Formation. 7. 9. 10, 18, 31, 32, 41: pls 1,6.7. $13,14,16.19$

Domengine Sandstone. 41

Dominican Republic, 8

Douglas County, Oreg., 31

Eaton, J. E., cited, 38

Ecuador, 6. 8, 11, 23. 38

edulss, Ostrea, 25, 27

Eel River, Calif., 33

eldridget, Ostrea, 18, 19, 22

Pycnodonte? (Crenostrea?, 18, 22. pl 21

ynezana, Crassostrea, 19

Ostrea $18,19,22$

Emperador Limestone Member. La Boca Formation, 22 42

englekyt, Crassostrea?. 36, 38: pls. 20, 22

Ostrea, 38

Eostrea. 27

(Eostrea) puelchana, Ostrea, 27

erici, Ostrea, 19, 33

Pycnodonte, 19

Pycnodonte), 18, 19; pl. 12

Estrella Valley, Calif . 9, 36

estrallensis, Spondylus, 8

estrellanus, Lyropecten, 9

Pallum, 9

Spondvlus, 8; pl. 5

Etchegoin Formation, 11, 12, 13, 26, 28, 41; pls. 6, 9,30

eucorrugata. Crassostrea?, $36,39,40$; pls. 25, 26, 27

Ostrea titan, 39

Europe, 13,30

excavata, Lima, 15

Exogyrinae, 18

\section{F}

Fernando Formation, 8, 11, 13, 15, 17, 19, 25. 26, 28, 41 pls. 9,10

fettkeı, Acutostrea idriaensıs, 27,30; pls. 30, 32, 33 Ostrea, 30 idraensis, 30,3

fischert, Ostrea, 22

fisheri, Ostrea, 22, 23

Fleminostrea, 40

Fossil localities, 40

Foxen Mudstone, 19, 41

fragills, Lima, 13

Fresno County, Calif, , 36, 39, 40

freudenbergi, Ostrea, 34, 38

Striostrea?, 33, 34; pls. 26,27

Gabb, W. M., cited, 33, 34

Galapagos Islands, 6, 23, 32 Gaviota Formation, 33, 42; pl. 29

Gaviota Pass, Calif., 36

Geologic formations cited 41 gibbosa, Plicatula, 6

giganteus, Pecten (Hinnites). 7

gigas, Crassostrea, 35

Gloria Formation $12,19,26,29,38,42$

Golfo de California, 6, 8, 23, 27, 38

golıath, Lima, 15

granti, Placunanomia, 11, 12; pl 6

gregerseni, Astrodapsis, 41

Gryphaea, 22

Gryphaeidae, 17

Gryphaeostrea, 18

avtcult formts, 18: pl. 19

Gulf of Calıfornia. 38

Gurabo Formation, 8, 42

hautensis, Hyotıssa, 21, 22

Ostrea, 20, 24, 26

vespertina, Ostrea, 24, 25

haleyi, Odontogrvphaea, 31

Ostrea, 30, 31; pl. 29

hamillus, Anomia, 11

hamlini, Acesta (Acesta), 14, 15; pl. 10

Lima. 15

(Acesta), 15

hannat. Anomıa. 9, 10: pl 5

hanniball, Placunanomıa, 11,12; pls 7,8

Harry, H W. cited, 17, 20, 28, 38

haseltinet, Acesta, 15

Acesta (Plicacesta), 14, 15; pls. 9, 10 Lima, 15

heermannı, Ostrea, 20,21, 24, 25, 26

Pycnodonter. 21 (Pycnodonte?). 18, 21: pls. 13.14,16,17

hemphillı, Lima, 16

Lima (Limarla), 16

Limaria (Limaria) 14, 16, pls. 7,8

hertlein, Ostrea, $39 ;$ pls. 20, 22

(Hinnites) glganteus, Pecten, 7

howell, Ostrea, 19,20,39

Pycnodonte? 20, 21

$$
\text { (Pycnodonte?). 18, 20, pl. } 14
$$

hvotıs, Hyotıssa, 22, 23; pl. 16

Mytllus, 22

Hyotissa, 17, 20, 22

haitensts, 21.22

hyotıs, 22, 23; pl. 16

hyotissa, 23

quercinus, 23

tryoni, 17,20

hyotıssa, Hyotıssa, 23

\section{I, J, K}

Idriaensis. Acutostrea idriaensis, 27,31, pls 13,14, 16 ,

Ostrea. 30, 31, 32

fettkel. Acutostrea, 27,30: pls 30,32, 33 Ostrea, 30,31

idriaensts, Acutostrea, 27,31; pls. 13, 14, 16, 29 Imperial County, Calif., 10, 21, 26

Imperial Formation, 8, 10, 11, 21, 25, 26, 27, 29, 32, 38 , 42 ; pls. 2. 3, 6. 7, 8.11, 12, 13, 14, 15, 16, 31

inconspicua, Anomia, 9, 10; $\mathrm{pl}$.

Indo-West Pacific, 27

inezana. Spondylus, 7 ; pls. 2,9

Infierno Formation, 11, 12, 21, 23, 26. 27, 42

nornata, Anomia, 11

Placunanomia, 9

inornatus. Anomıa, 9, 11; pls 6.7

Pododesmus (Monaa), 9

Int roduction. 1

Irtdiscens, Ostrea, 37.38

lsidro Formation, 22, 25, 34, 40, 42; pls. 26, 27, 31

lsla Carnen, 23

lsla Cedros, 29

Isla Cerralvo, 23

Isla Coronados, 8

Isla la Plata, Ecuador, 8

Isla Maria Magdalena, 6

Isla Tres Marias, 25, 29
(Isolimea) Limea, 17

(Isolımea?), Limea?, 14, 17 claytonensts, Limea?, 14, 17; pl. 10

Jamaica, 8

Japan, 13, 15, 23, 27, 35 Jewett Sand, 19, 38, 42

Pyramid Hill Sand Member, 38, 42 Juncal Formation, 32, 42

Kamtschatka, 13, 31

Kern County, Calif., 12, 39

Kings County. Calif., 26, 39

Kirker's Pass, Calif. 34

L

La Boca Formation, 17

Emperador Limestone Member, 22, 42

Laguna de Scammon, 8, 19

Laguna des Isles de San Jose, Golfo de California. 6 La Jolla Group. 31, 32, 42

Delmar Formation, 41

Lake County, Calif, 5,30

lampe.Anomia, 11

larbas, Anomta, 11

laticaudata, Ostrea lurida, 26

Irgminuta, Crassostrea, 37

Ostrea. $35,36,37$ : pls. 28,29

Lima, 13,14,15

agassızu, 15

auaua. 16

clarki. 16

claytonensis, 16.17

excavata. 15

fragltis, 13

gollath, 15

hamlini, 15

haseltines, 15

hemphill, 16

lima, 13

multıradıata, 14

orbignyi, 16

orcuttı, 16

packard $l, 16$

perrinı, 15 ; pls. 9,10

tetrica. 14

ledder, 13,14

(Acesta) hamlinı, 15

Lima. 13

(Lima) 14 veddert, 13,$14 ; \mathrm{pl} .10$

(Limarta) hemphill, 16

orcutti, 16

(Limatula) subauriculata. 17

lıma, Lima, 13

(Lima), Lima, 13

vedderı. Lıma, 13.14; pl. 10

Limacea, 13

Limaria, 14, 16

Limaria, 14, 16

(Limaria), 16

clarkl, 14, 16; pl. 10

hemphill, 14,16; pls. 7,8 orcuttl, 14. 16: pl. 9

(Limaria) Limaria, 16

clarki, Limaria. 14, 16; pl 10

hemphilli, Lima, 16

Ltmaria, 14, 16; pls. 7.8

urcuttl, Lima, 16

Limarıa, 14, 16; pl. 9

Limatula, 14,17

subauriculata, 14,17, pl 9

(Limatula) subauriculata, Lima, 17

Limatula, Anomia, 10

Limea, 17

Isolimea, 17

Limea!, 14, 17

(Isollmea?), 14, 17 clavtonensis. 14,$17 ; \mathrm{pl} .10$

Limıdae, 13

Lnatula, Anomia, 10 
Lincoln Creek Formation, 41 lithobleta, Placunanomia, 12

loeli. Ostrea, 20, 21, 39

Ostrea vespertına, 21

Pycnodonte?, 20

(Pycnodonte?), 18, 20,21: pl. 18

Lomita Marl, 29

Lomita Marl Member, San Pedro Formation, 42

Lopha, 24. 25

angelica, 26

Lopha?, 23, 24

veatchis, 24, 25

"Lopha", 24

(Lopha), 23, 24 veatchu, 23,$24 ;$ pl. 17

(Lopha), Lopha?, 23, 24

megodon, Ostrea, 29

veatchu, Lopha, 23, 24; pl. 17

Lophinae, 24, 25

Los Angeles County, Callf., 15

Lower Lake, Calif, 29

Lower Lake Village, Calif. 15

lurida, Ostrea. 26, 28, 29 laticaudata, Ostrea, 26

Lyropecten, 9

estrellanus, 9

macrochisma, Anomia, 13

macroschisma, Monia, 13

Pododesmus, 13

(Monıa), 12,$13 ;$ pls. $7,8,9$

Madagascar, 23, 33

magnolia. Pecten, 34

Maria Madre Island, 12

Marquer Formation, 6, 23, 24, 25, 26. 27, 42: pls. 1, 32 34

Martinez Formation 5, 15, 16, 17, 29, 30, 31, 42; pls 1, 9 $10.29,30$

Matilija Sandstone, 32, 42

Mazatlan. Mexico, 5, 28, 32

McLure Shale Member, Monterey Formation, 37

mcgoniglensıs. Anomia, 9, 10, 11

mcgoniglensis. Anomia?, 9, 11; pl. 5

Medill Sand, 29, 42

Mediterranean Sea, 28

megodon, Agerostrea, 29

Ostrea, 29

(Agerostrea), 29

(Alectryonia), 29

(Lopha), 29

Ostreola?, 27, 29: pls. 32,34

cerrosensts, Ostrea, 29

Merced Formation, 13, 28, 42

Mesodesma, 28

messor, Ostrea, 29

Mexico, 23, 26, 27, 29

meguelensts, Acutostrea? 27, 32; pl. 33

Ostrea, 29,32

Mindego Basalt, 38, 42

Modelo Formation, 37, 42

Monta, 12, 13

macroschisma, 13

(Monia) cepto, Pododesmus, 13

inornatus, Pododesmus, 9

macroschisma, Pododesmus, 12, 13; pls. $7,8,9$

Monterey, Calif, 13

Monterey Bay, Cahf., 16

Monterey County, Calıf, 10, 28, 38

Monterey Formation, 14, 42

Beechers Bay Member, 34, 4

McLure Shale Member, 37

Saltos Shale Member, 34, 42

Monterey Group, 42

Monterey Shale. 8, 14, 22, 42; pl. 10 Saltos Shale Member. 34, 42

morl, Acesta, 15

Mulberry Seamount, 14

multiradıata, Acesta (Acesta), 14; pl. 10 Lima, 14
Mytilus hyotis, 22

$$
\text { N. O }
$$

Negritos, Peru, 8

Neopycnodonte, 23, 26 cochlear, 23

Neopycnodonte?, 23, 26 cochlear, $23 ; \mathrm{pl} .32$

Neroly Formation, 35

Neroly Sandstone, 37 San Pablo Group, 37, 42

newcombei, Pododesmus, 13

New Idria, Calif., 30, 31

New Zealand. 13, 22

Niguel Formation, 13, 17, 19, 25, 26, 42

North America, 11, 13, 30, 33

Odontogryphaea haleyi, 31

Olcese Sand, 39, 42

Orange County, Calif., 14

orbignyı, Lima, 16

orcuttl, Lima, 16

Lima (Limarta), 16

Limaria (Limaria), 14,16; pl. 9

Oregon, 11

oregonensis, Ostrea, 31

Ostrea, 20, 25, 27, 28, 29, 34, 38

altatemblorensis, 39 ; pls. 21,24

andersonı, 36

angelica, 24, 25, 26, 28

angermanni, 25

appressa, 33

arnoldi. 39; pls. 19, 20

ashleyi, 38, 39

atwoodii, 28

aviculiformis, 18

bourgeotsii, $32,34,35,36,39$

buwaldana, 30 ; pl. 30

californica, 37, 38

osunai, 40

cerrosensis, 29,$30 ;$ pls. 32,34

chilensis, 34, 37, 38; pl. 24

cierboensis, 35, 36, 39, 40, 41; pls. 25. 26

cochlear 23

columbiana, 31

columbiensis, 37,38

conchaphila, 28

palmula, 32

corrugata, 39

corteziensts, 37,$38 ; \mathrm{pls} .26,28$

crandalli. 30 ; pl. 32

cumingiana, 23,26 ; pls. 32,34

denselamellos $a, 27$

edulis, 25, 27

eldridgei, 18.19, 22

vnezana, $18,19,22$

englekvt, 38

erici, 19, 33

fettkel, 30

fischeri, 22

fisheri, 22, 23

freudenbergi, 34,38

hattensts, 20,24, 26 vespertina, 24.25

haleyt, 30, 31; pl. 29

heermannt, 20.21, 24, 25, 26

hertleinl, $39 ;$ pls. 20,22

howelli, 19,20,39

tdriaensıs, $30,31,32$ fettkel, 30,31

irdescens, 37,38

jacobaea, 22

ligmtnuta, $35,36,37$; pls. 28,29

loelt, 20, 21, 39

lurida, 26, 28, 29 laticaudata, 26

megodon, 29

cerrosensıs, 29

messor 29

miguelensis, 29, 32

oregonensis, 31

palmula, 26, 32 panzana, 36,37 ; pl. 23

prior, 36

reef, 41

sellaformıs thomasil, 25

simiensis, 30

stewart $, 22,31$

subjecta, 36,37 ; pl. 23

tayloriana, 19, 33

titan, $20,34,35,36,37,38,40$

andersont, 36; pl. 24

corrugata, 20,39

eucorrugata, 39

perrini, 35

prior, $35,36,37$; pls. 27,29

subtitan, 34,36

tutan, 35,36

vaquerosensis, 38

veatchii, $20,21,24,25,26 ; \mathrm{pl} .17$

venturana, 29

respertina, 20,21,24,25,26.32,39; pl. 34

loelt, 21

sequens, $25,26,28 ; \mathrm{pl} .15$

virginica, 33,38

weaver, 27,$29 ; \mathrm{pl} .29$

wiedevi, 20,21,24, 26, 39

sp. 10

(Agerostrea) megodon, 29

(Alectryonia) megodon, 29 plicata, 25

(Crassostrea) columbiensis, 37 titan, 35

(Eostrea) puelchana, 27

(Lopha) megodon, 29

Ostrea, 28

(Ostrea), 27, 28 atwood $u, 27,28 ;$ pl. 30

(Ostrea), Ostrea, 27,28

atwoodi, Ostrea, 27, 28; pl. 30

Ostrea-Pecten "reef", 41

Ostreacea, 17

ostreaformis, Plicatula, 5

Ostreidae 17,24

ostreıformıs. Plicatula. 5 ; pl. 1

Ostreinae, 27,29

incertae sedis, 29

Ostreola. 25,28

ronchaphila, 27, 28; pl. 30

Ostreola?, 27, 29

megodon, 27, 29; pls. 32,34

venturana. 27, 29; pls. 31,33

osunat, Crassostrea? californica, 36, 40; pl. 27

Ostrea californica, 40

ovsters, 17.31

$\mathrm{P}$

Pacific, eastern, 9, 27, 28, 32

pacilus, Anomia, 11

packard, Lıma, 16

Painted Rock Sandstone Member, Vaqueros Formation, 38,42

Paita, Peru. 11

Pallium estrellanus, 9

palmula, Ostrea, 26, 32

Ostrea conchaphla. 32

Saccostrea, 32,$33 ; \mathrm{pl} .18$

Palos Verdes Sand, 28, 29, 42

Palos Verdes Sandstone, 16

Panama, 17, 22, 28

Pancho Rico Formation, 13, 28, 42; pl. 30

Panza Valley, Calif., 36

panzana, Ostrea, 36, 37; pl. 23

Paso Robles Formation, 26, 28, 42

Pecten, 16

magnolia, 34

(Hinnites) giganteus, 7

Pectinacea, 5, 6

Pectinidae, 6

Pelag, Gorgoniis, 23

Pelecypods, 5

penicillata, Plicatula, 5, 6; $\mathrm{pl} .1$ 
perrini, Acesta, 15

Lima, 15; pls. 9, 10

Ostrea titan, 35

Spondylus, 6, 7; pls. 2, 9

Striostrea? bourgeoisii, 33, 35, 37; pls. 26, 27 Peru, 29

peruviana, Anomia, 9, 10, 11; pl. 6

Philippine Islands, 35

Pico Formation, 13, 25, 26, 32, 42

Placunanomia, 11, 12, 13

californica, 11, 12; pl. 6

cepio, 13

cumingi, 12

cumingii, 12

granti, 11,$12 ; \mathrm{pl} .6$

hannibali, 11,$12 ;$ pls. 7,8

inornata, 9

lithobleta. 12

plicata, 12

Plicacesta, 15

(Plicacesta), Acesta, 15 haseltinei, Acesta, 14, 15; pls. 9, 10

plicata, Ostrea (Alectryonia), 25

Placunanomia, 12

Plicatula, 5

gibbosa, 6

ostreaformis, 5

ostreiformis, $5 ; \mathrm{pl} .1$

penicillata, 5,$6 ;$ pl. 1

spondylopsis, 5, 6; pl.1

(Plicatula), 5

(Plicatula). Plicatula, 5

Plicatulidae, 5

Pododesmus, 9, 12, 13

cepio, 13

macroschisma, 13

newcombei, 13

(Monia) cepio, 13

inornatus, 9

macroschisma, 12,13; pls. 7, 8,9

(Pododesmus), 13

(Pododesmus), Pododesmus, 13

Potato Harbor Formation, 13, 42

Powell, C. L., cited, 21

princeps, Spondylus, 6,8 ; pls. $3,4,5$

Spondylus princeps, 8

princeps, Spondylus, 8

prior, Crassostrea titan, 37

Ostrea, 36

Procedure, 1

titan, 35, 36, 37; pls. 27, 29

Promantellum, 16

puelchana, Ostrea (Eostrea), 27

Puget Sound, Wash., 13, 28

Purisima Formation, 19, 26, 42

Purpose and scope, 1

Pycnodonte, 17, 18, 20, 21

erici, 19

ynezana, 19

Pycnodonte, 18

(Pycnodonte) erici, 18, 19; pl. 12

ynezana, 18.11

Pycnodonte?, 18, 20

heermanni, 21

howelli, 20, 21

loeli, 20

wiedeyi, 20, 21, 24

Crenostrea, 22

(Crenostrea?), 22

eldridgei, 18,$22 ; \mathrm{pl} .21$

stewarti, 18,$22 ;$ pl. 19

(Pycnodonte?), 18, 20

heermanni, 18,21; pls. 13,14,16, 17

howelli, 18, 20; pl. 14

loeli, 18, 20,21; pl. 18 wiedeyi, 18, 20; pl. 15

(Pycnodonte) erici, Pycnodonte, 18, 19; pl. 12 ynezana, Pycnodonte, $18 ; \mathrm{pl} .11$

(Pycnodonte?), Pycnodonte?, 18, 20 heermanni, Pycnodonte?, 18, 21; pls. 13, 14, 16, 17 howelli, Pycnodonte?, 18, 20; pl. 14
(Pycnodonte?)—Continued

loeli, Pycnodonte?, 18,21; pl. 18 wiedeyi, Pycnodonte?, 18, 20; pl. 15

Pycnodonteinae, 17, 18, 19, 21, 30, 40

Pyramid Hill Sand Member, Jewett Sand, 38, 42

\section{$\mathbf{Q}, \mathbf{R}$}

Quadriostrea, 30

Quail Canyon Sandstone Member, Vaqueros Formation, 22,42

quercinus, Hyotissa, 23

Rancho El Refugio, 23

Rapana vaquerosensis, 34

References cited, 42

regius, Spondylus, 6

Remond, Auguste, quoted, 34

Repetto Formation, 41

Rincon Shale, 8, 11, 21, 42

Rose Canyon Shale, 7, 22, 42; pls. 2, 19

Round Mountain Silt, 37, 42

Sacate Formation, 32, 42

Saccostrea, 30, 32

palmula, 32, 33; pl. 18

Saint Elena, Columbia, 38

Salada Formation, $32,40,42 ;$ pl. 27

Saltos Shale Member, Monterey Formation, 34, 42

Monterey Shale, 34, 42

San Antonio Creek, Calif., 34

San Clemente Island, 13, 14

San Diego, Calif., 16

San Diego County, Calif., 7, 11, 16, 22, 30

San Diego Formation, 13, 16, 17, 25, 26, 27, 29, 42; pl. 9 San Felipe, Calif., 21

San Francisquito Canyon, Calif., 37

San Gregorio Lagoon, Calif., 34

San Ignacio Formation, 26, 42

San Joaquin Formation, 12, 26, 28, 42; pls. 15, 30

San Lorenzo Creek, Calif., 28

San Luis Obispo, Calif., 36, 39

San Marcos Formation, 8, 23, 25, 26, 29, 38, 42

San Marcos Pass, Calif., 33

San Miguel Island, Calif., 32

San Nicolas Island, 28

San Onofre Breccia, 38, 39, 42

San Pablo Formation, 35, 37, 42; pls. 23, 25, 26

San Pablo Group, Briones Sandstone, 35 Neroly Sandstone, 37, 42

San Pedro Formation, 13, 42

Lomita Marl Member 42

Timms Point Silt Member, 13, 42

San Pedro Sand, 16, 28, 29, 42

San Ramon Sandstone, 10, 42; pl. 6

Santa Barbara County, Calif., 11, 19, 29, 36, 38, 40

Santa Margarita Formation, 9, 13, 14, 26, 35, 36, 37, 40, 42 ; pls. $5,23,24,25,27$

Santa Rosa Island, Calif., 20, 21, 24

Santa Rosalia Formation, 23, 42

Santa Susana Formation, 15, 16, 42

Santa Ynez Mountains, 34

Santos Shale Member, Temblor Formation, 42

Saugus Formation, 11, 13, 25, 26, 28, 42

sellaformis thomasii, Ostrea, 25

Sepultura Formation, 15, 42

sequens, Ostrea vespertina, 25, 26, 28; pl. 15

Sierra Monica, Calif., 36

Simi Conglomerate, 30,$42 ;$ pl. 34

Simi Hills, Calif., 15, 30

simiensis, Acutostrea, 27, 30; pl. 34

Ostrea, 30

simplex, Anomya, 1

Sisquoc Formation, 19, 42

Sobrante Sandstone, 37, 42

Soda Lake Sandstone Member, Vaqueros Formation, 22 42

Sonora, Mexico, 38

Sooke Formation, 19, 42

sookensis, Crassostrea, 19
South America, 13

Spondylidae, 6

spondylopsis, Plicatula, 5, 6; pl. 1

Spondylus, 6, 9

bostrychites, 6,8 ; pls. $2,3,9$

calcifer, 6,$8 ; \mathrm{pl} .4$

carlosensis, 6, 7; pl.

cliffensis, 6, 7; pl. 2

crassisquama, 8; pl. 3

estrallensis, 8

estrellanus, 8 ; pl. 5

inezana, 7 ; pls. 2,9

perrini, 6,7 ; pls. 2,9

princeps, 6,$8 ;$ pls. $3,4,5$

princeps, 8

regius, 6

victoriae, 8 ; pls. 3,4

Stanton, R. J., Jr., cited, 35, 37

Stenzel, H. B., cited, 17, 34, 35, 37, 40

stewarti, Ostrea, 22, 31

Pycnodonte? (Crenostrea?), 18, $22 ; \mathrm{pl} .19$

Striostrea, 30, 32, 34, 35, 39

Striostrea?, 33

appressa, 33 ; pls. 12,16

bourgeoisii bourgeoisii, 33, 34, 37; pls, 25, 26

perrini, $33,35,37$; pls. 26,27

freudenbergi, 33,34 ; pls. 26,27

subtitan, 33, 34; pl. 22

tayloriana, $33 ;$ pl. 29

subauriculata, Lima (Limatula), 17

Limatula, 14, 17; pl. 9

subcostata, Anomia, 9, 10; pls. 6, 7, 8

subjecta. Ostrea, 36, 37; pl. 23

Submantellum, 16

subtitan, Ostrea titan, 34, 36

Striostrea?, 33, 34; pl. 22

Suzuki, Takeo, cited, 34, 37, 38

Systematics, 5

\section{$\mathrm{T}$}

tayloriana, Ostrea, 19, 33

Striostrea?, 33; pl. 29

Tejon Formation, 7, 15, 32, 33, 42; pl. 10

Coldwater Sandstone Member, 41

Cozy Dell Shale Member, 41

Tejon Group, 33, 34

Temblor Formation, $33,34,35,38,39,42$; pls. 12, 16, 19 , 20,22

Saltos Shale Member, 42

Wygal Sandstone Member, 19, 42

tetrica, Lima, 14

thomasii, Ostrea sellaformis, 25

Timms Point Silt, 28, 29

Timms Point Silt Member, San Pedro Formation, 13, 42 titan, Crassostrea, 34, 35, 36, 37, 38; pls. 23, 24, 27, 28 ,

Crassostrea titan, 33, 35

Ostrea, 20, 34, 35, 36, 37, 38, 40 (Crassostrea), 35 titan, 35, 36

andersoni, Crassostrea, 37 Ostrea, 36; pl. 24

corrugata, Ostrea, 20, 39

eucorrugata, Ostrea, 39

perrini, Ostrea, 35

prior, Crassostrea, 37

Ostrea, $35,36,37$; pls. 27,29

subtitan, Ostrea, 34, 36

titan, Crassostrea, 33, 35 Ostrea, 35, 36

Tomales Formation, 42

Topanga Formation, 21, 35, 36, 37, 42; pl. 23

Tortugas Formation, 21, 34, 42

Towsley Formation, 13, 16, 26, 42

Transverse Ranges, 22

Trinidad, 20

tryoni, Hyotissa, 17, 20

tumidus, Astrodapsis, 41

Turritella bed, 34, 40

Turtle Bay, 24 
U, V, W, Y

Umpqua Formation, 31, 42

Vancouver Island, B.C. 19

Vaqueros Formation, 7, 8, 10, 11, 19, 20, 21, 22, 25, 29, 32, $34,38,42$; pls. $2,5,6,9,11,14,15,18,20$, $21,22,25,31,33$

Painted Rock Sandstone Member, 38, 42 Quail Canyon Sandstone Member, 22, 42 Soda Lake Sandstone Member, 22, 42 vaquerosensis, Anomia, 9, 10; pls. 5, 6

Crassostrea, 38

Crassostrea?, 36, 38; pls. 21, 25

Ostrea, 38

Rapana, 34 veatchii, Lopha?, 24, 25

("Lopha"), 23, 24; pl. 17

Ostrea, 20, 21, 24, 25, 26; pl. 17

Vedder, J. G., cited, 37

vedderi, Lima, 13, 14

Lima (Lima), 13, 14; pl. 10

Ventura County, Calif., 10, 16, 20, 22, 30, 34

venturana, Ostrea, 29

Ostreola?, 27, 29; pls. 31,33

vespertina, Dendostrea?, $21,23,25,26,32$; pls. $11,12,13$, $14,15,16$

Ostrea, 20, 21, 24, 25, 26, 32, 39; pl. 34

haitensis, 24, 25

loeli, Ostrea, 21

sequens, Ostrea, 25, 26, 28; pl. 15

victoriae, Spondylus, 8 ; pls. 3,4 virginica, Crassostrea, 33,35

Ostrea, 33,38

Vokes, H. E., cited, 30, 31

Washington, 15, 31

weaveri, Ostrea, 27, 29; pl. 29

wiedeyi, Ostrea, 20, 21, 24, 26, 39

Pycnodonte?, 20, 21, 24

(Pycnodonte?), 18, 20; pl. 15

Wiley Canyon, Calif., 7

Willapa Harbor, Wash., 28

Woodring, W. P., cited, 17, 32, 37 quoted, 20

Wygal Sandstone Member, Temblor Formation, 19, 42

ynezana, Crassostrea eldridgei, 19

Ostrea eldridgei, 18, 19, 22

Pycnodonte, 19

(Pycnodonte), 18; pl.11 



\section{PLATES 1-34}

[Contact photographs of the plates in this report are available, at cost, from the U.S. Geological Survey Photographic Library, Federal Center, Denver, Colorado 80225] 


\section{PLATE 1}

Figures 1-3. Plicatula ostreiformis Stanton (p. 5).

1, 3. Syntypes USNM 157838. Martinez Formation, California, Paleocene.

2. Hypotype UCMP 11680 ( $\times 2.0$; Dickerson, 1914, pl. 9, fig. 12).

Martinez Formation, California, Paleocene.

4, 6, 8, 9. Plicatula pencillata Carpenter (p. 5 ).

4, 6. Hypotype UCMP 15927 ( $\times$ 3.0; Durham, 1950, pl. 13, fig. 5).

Unnamed Pleistocene strata, Isla Coronado, Baja California Sur.

8, 9. Hypotype UCMP 15921 ( $\times 3.0$; Durham, 1950, pl. 13, fig. 2).

Unnamed Pleistocene strata, Isla Coronado, Baja California Sur.

5. Spondylus carlosensis Anderson (p. 6).

Holotype CAS 56. Domengine Formation, California, Eocene.

7, 10. Plicatula spondylopsis Rochebrune (p. 6).

Hypotype UCMP 14898 (Durham, 1950, pl. 15, fig. 2). Marquer Formation, Baja California Sur, Pliocene. 


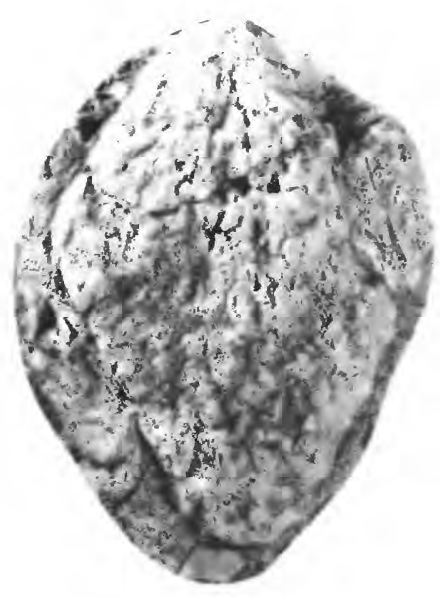

1

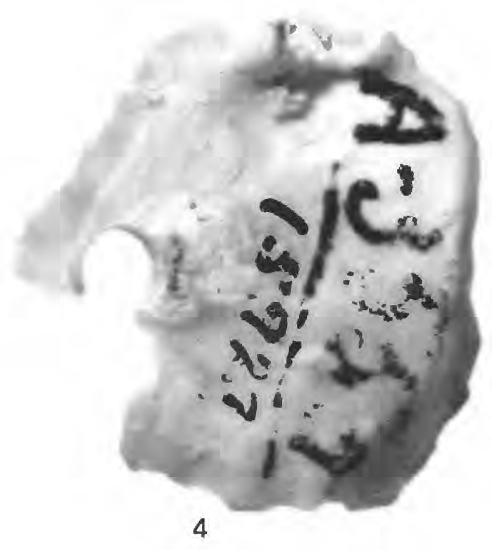

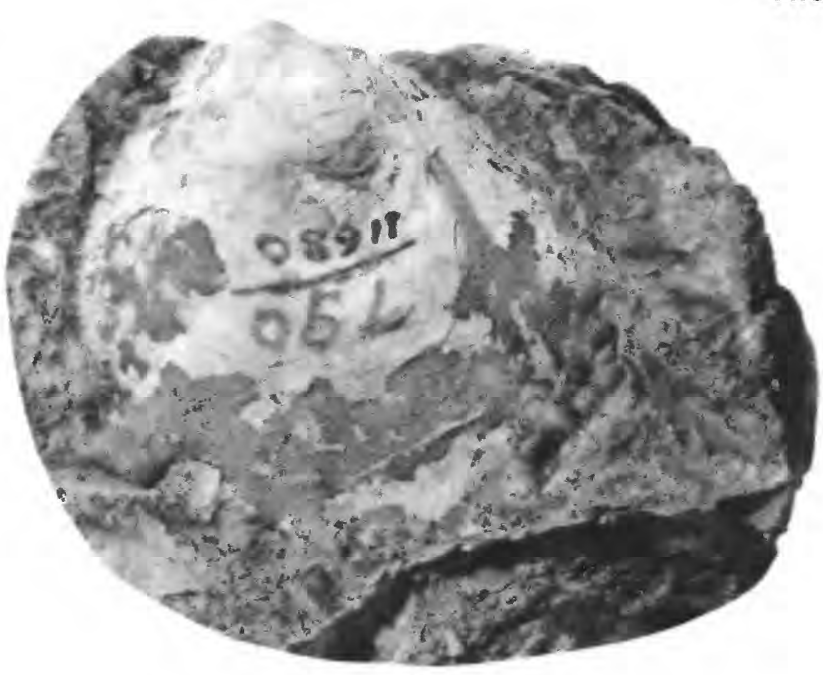

2
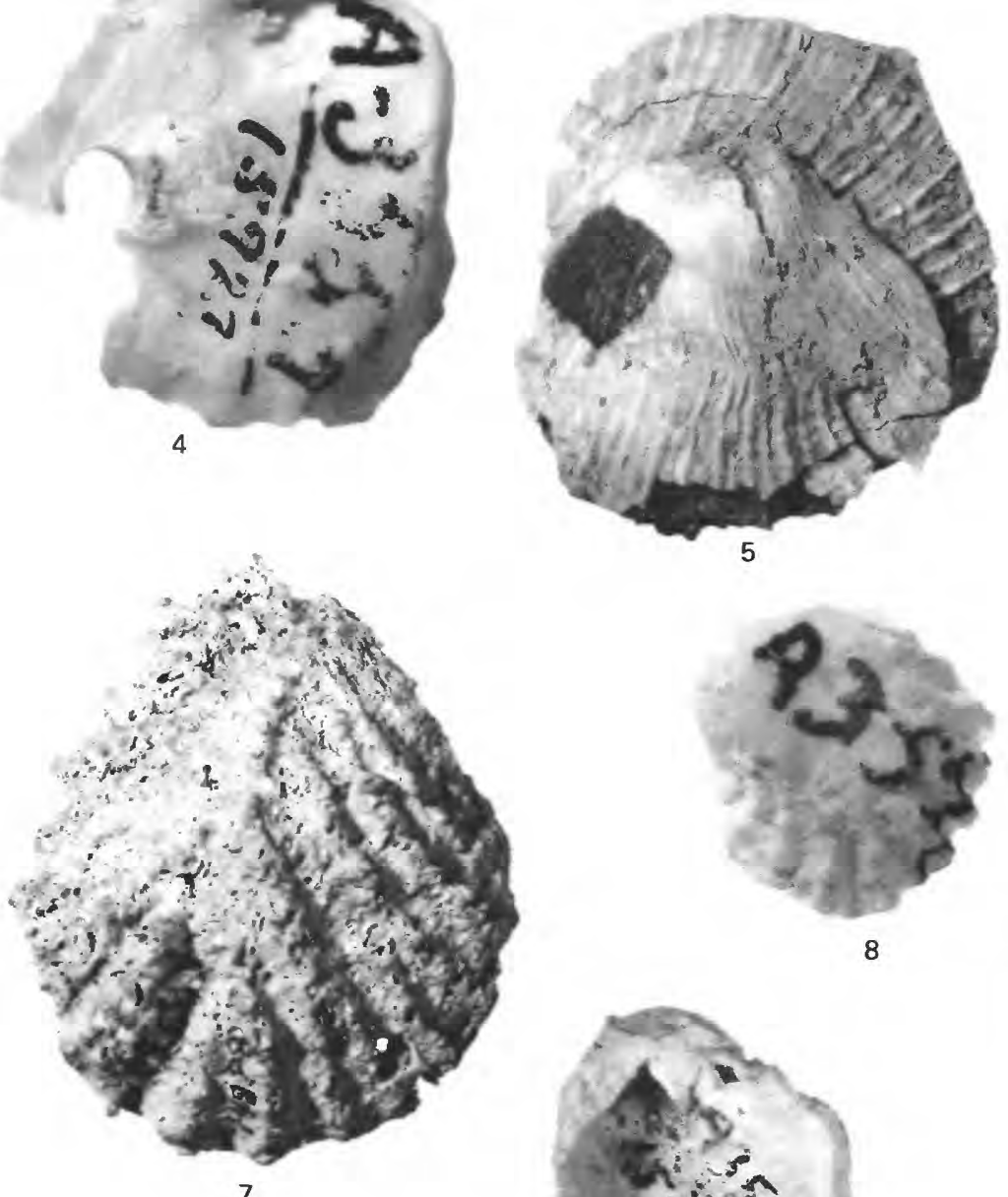
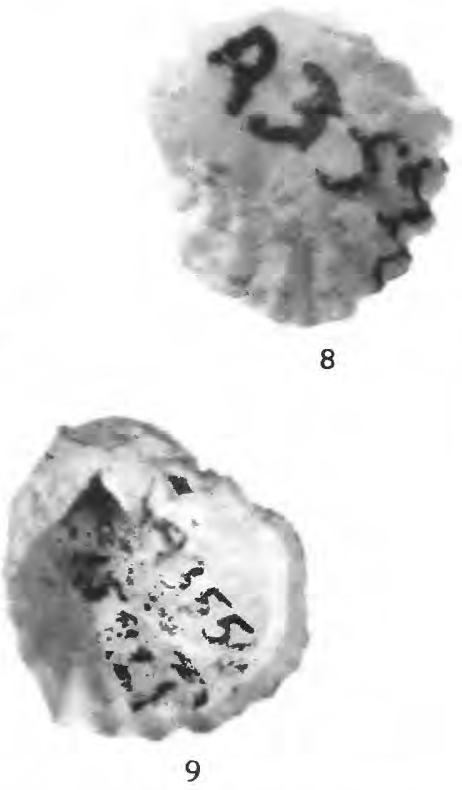

PLICATULA, SPONDYLUS
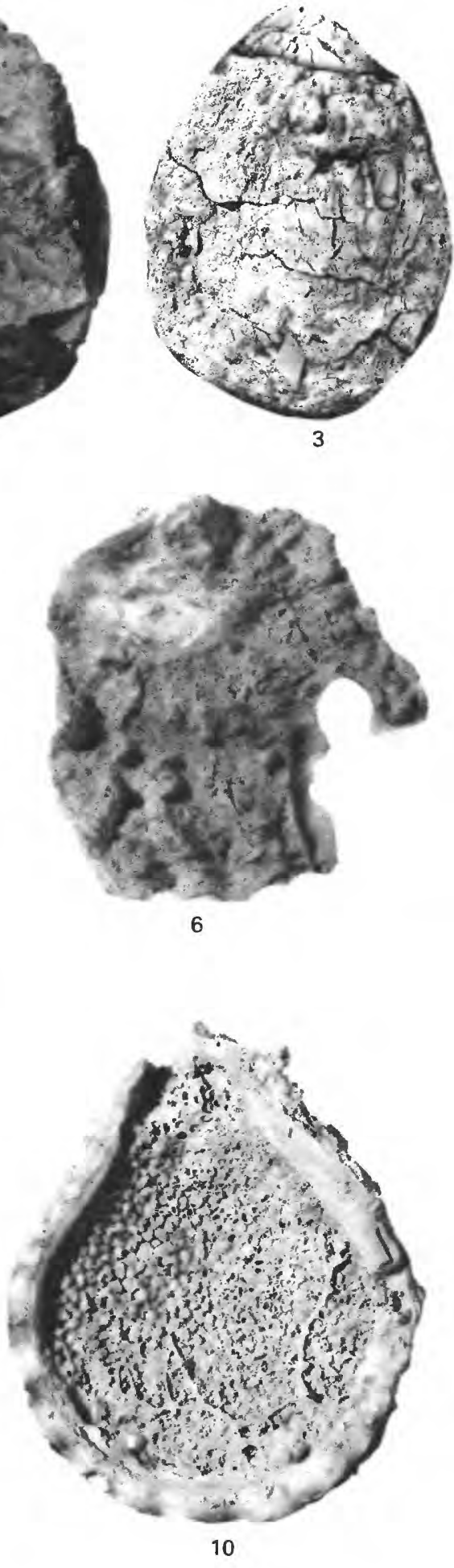


\section{PLATE 2}

Figures 1, 4-7. Spondylus perrini Wiedey (p. 7).

1, 4, 5. Holotype SDNM 28. Vaqueros Formation, California, Oligocene and Miocene.

6, 7. Holotype of Spondylus inezana Wiedey SDNM 29. Vaqueros Formation, Oligocene and Miocene.

2. Spondylus bostrychites Guppy (p. 8).

Hypotype UCMP 32279 (G D. Hanna, 1926a, pl. 24, figs. 3, 4). Imperial Formation, California, Miocene or Pliocene.

3. Spondylus cliffensis M. A. Hanna (p. 7).

Holotype (plaster cast) UCMP $31025(\times 2.0)$. Rose Canyon Shale, California, Eocene. 

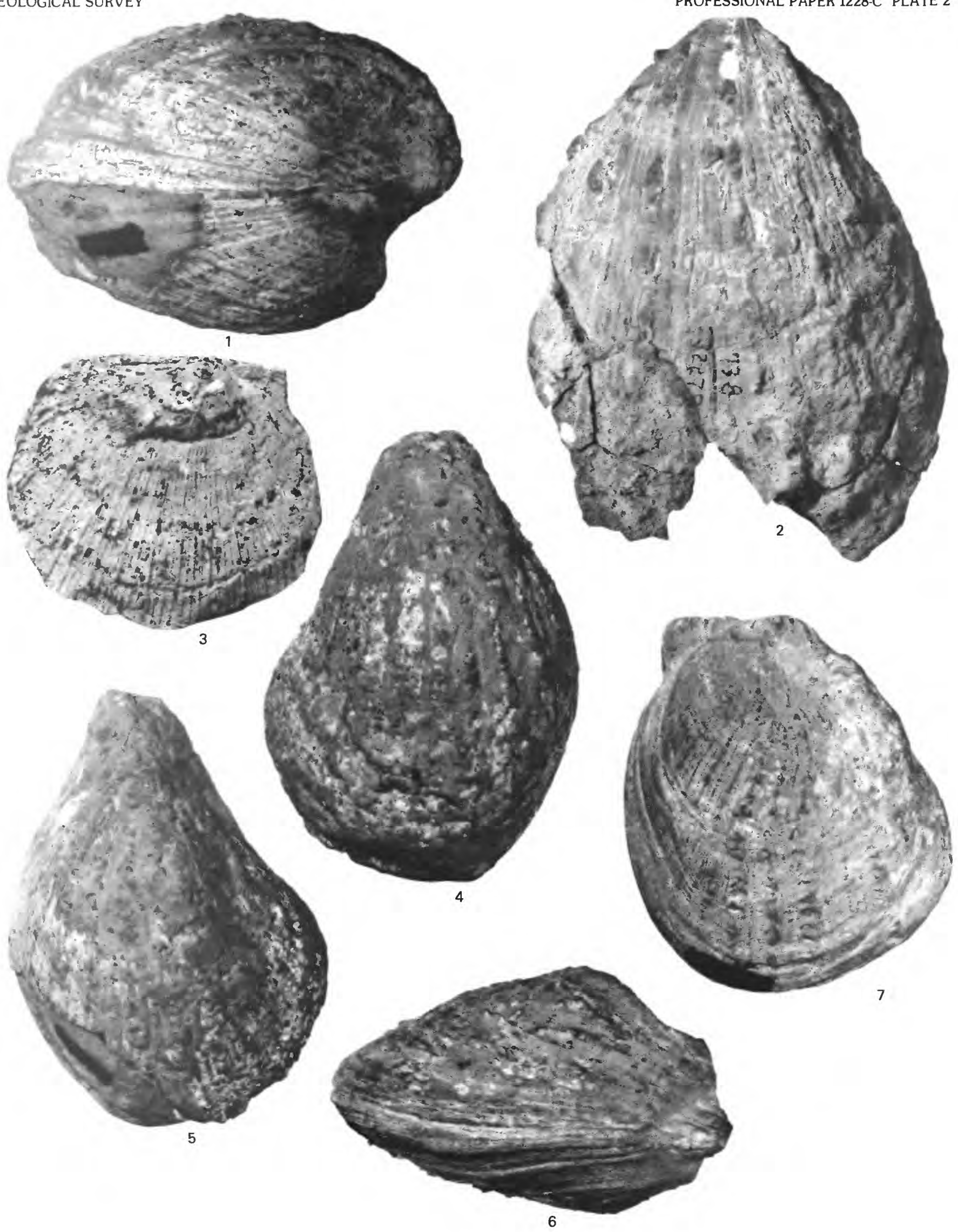


\section{PLATE 3}

Figures 1,3-10. Spondylus princeps Broderip (p. 8).

1, 6, 8. Hypotype CAS 057755 ( $\times 0.8$ ). Peru, Holocene.

$3,4,10$. Spondylus victoriae Sowerby of Durham

UCMP 15418 ( $\times 0.8 ; 1950$, pl. 15, fig. 3). Unnamed

Pleistocene strata, Isla Coronado, Baja California Sur.

5, 7, 9. Spondylus crassisquama Lamarck of Durham

Hypotype UCMP 15414 ( $\times 0.8 ; 1950$, p. 68, pl. 15, fig. 1).

Unnamed Pleistocene strata, Isla Carmen, Baja California Sur.

2. Spondylus bostrychites Guppy (p. 8).

Hypotype UCMP 32380 (G D. Hanna, 1926a, pl. 24, fig. 4). Imperial

Formation, California, Miocene or Pliocene. 

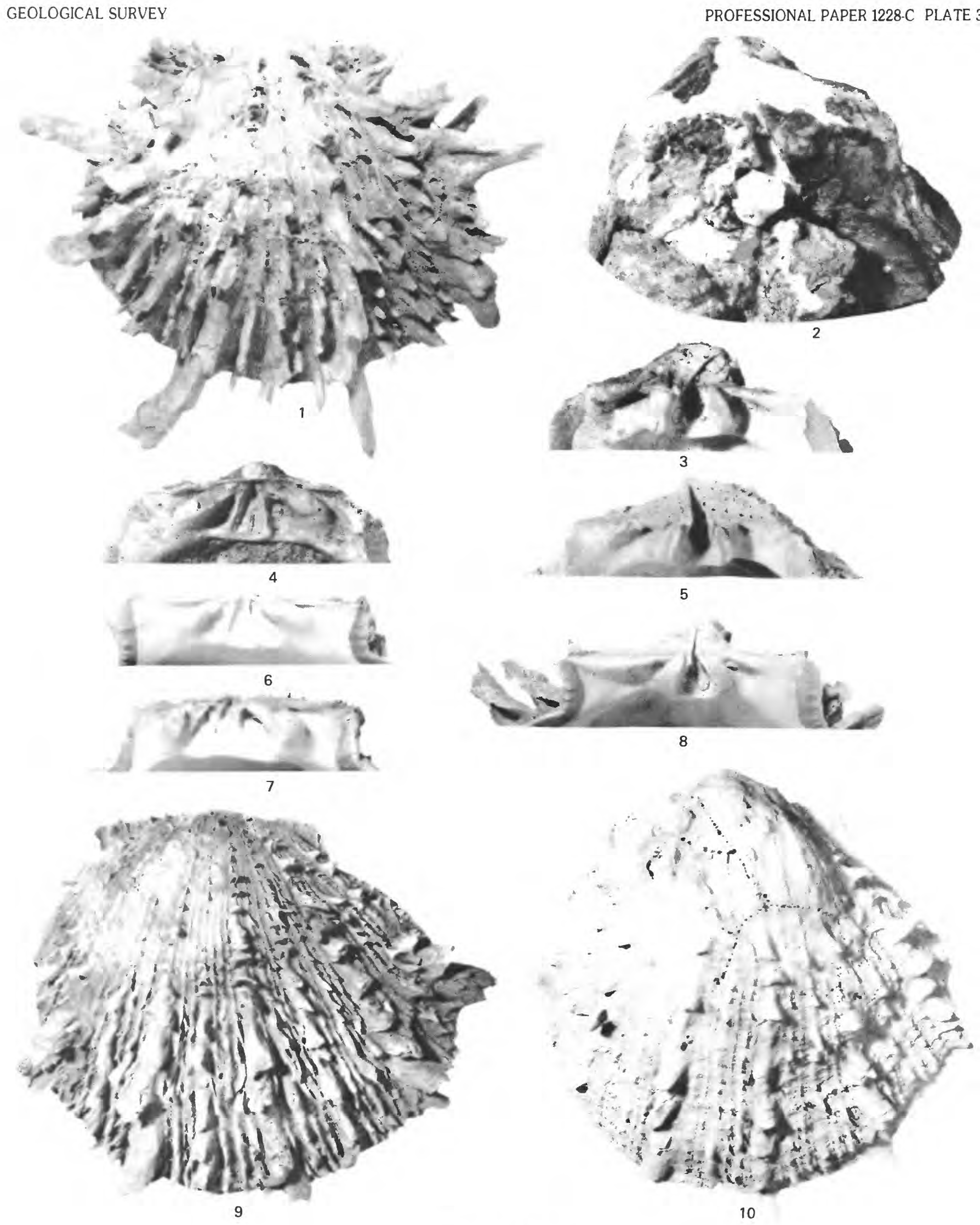

SPONDYLUS 
PLATE 4

Figures 1, 2, 4, 5. Spondylus calcifer Carpenter (p. 8).

CAS 41999 ( $\times$ 0.8). Isla Grassa, Sonora, Mexico, Holocene.

3, 6. Spondylus princeps Broderip (p. 8).

3. CAS 40504 ( $\times$ 0.9). Pira, Peru, Holocene.

6. Spondylus victoriae Sowerby of Durham ( $\times 0.8 ; 1950$, pl. 15, fig. 3). Unnamed Pleistocene strata, Isla Coronado, Baja California Sur. 

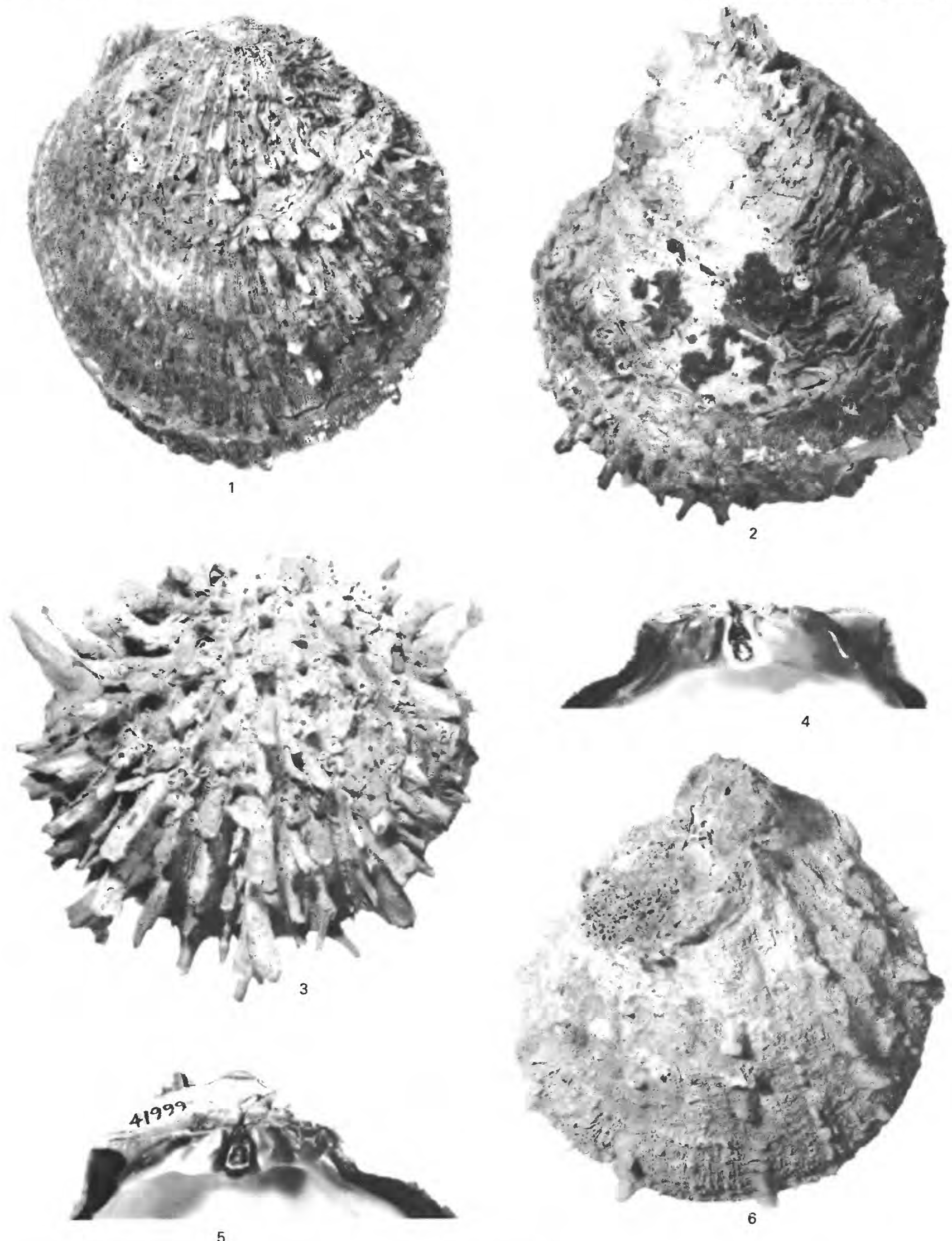


\section{PLATE 5}

Figures 1, 3. Anomia? mcgoniglensis M. A. Hanna (p. 11).

1. Syntype UCMP 31011 ( $\times$ 2.0). Delmar Formation, California, Eocene.

3. Syntype UCMP 31011 ( $\times 2.0$ ). Delmar Formation, California, Eocene.

2. "Spondylus estrellanus Conrad" (p. 8).

Holotype USNM 13312. Santa Margarita Formation, California, Miocene.

4, 5. Anomia hannai Wiedey (p. 10).

Holotype CAS/SU 514. Vaqueros Formation, California, Oligocene and Miocene.

6. Spondylus princeps Broderip (p. 8).

UCMP 15417 ( $\times$ 0.8). Unnamed Pleistocene strata, Isla Carmen, Baja California Sur.

7. Anomia vaquerosensis Loel and Corey (p. 10).

Holotype UCMP 31758 ( $\times 1.5$ ). Vaqueros Formation, California, Oligocene and Miocene. 

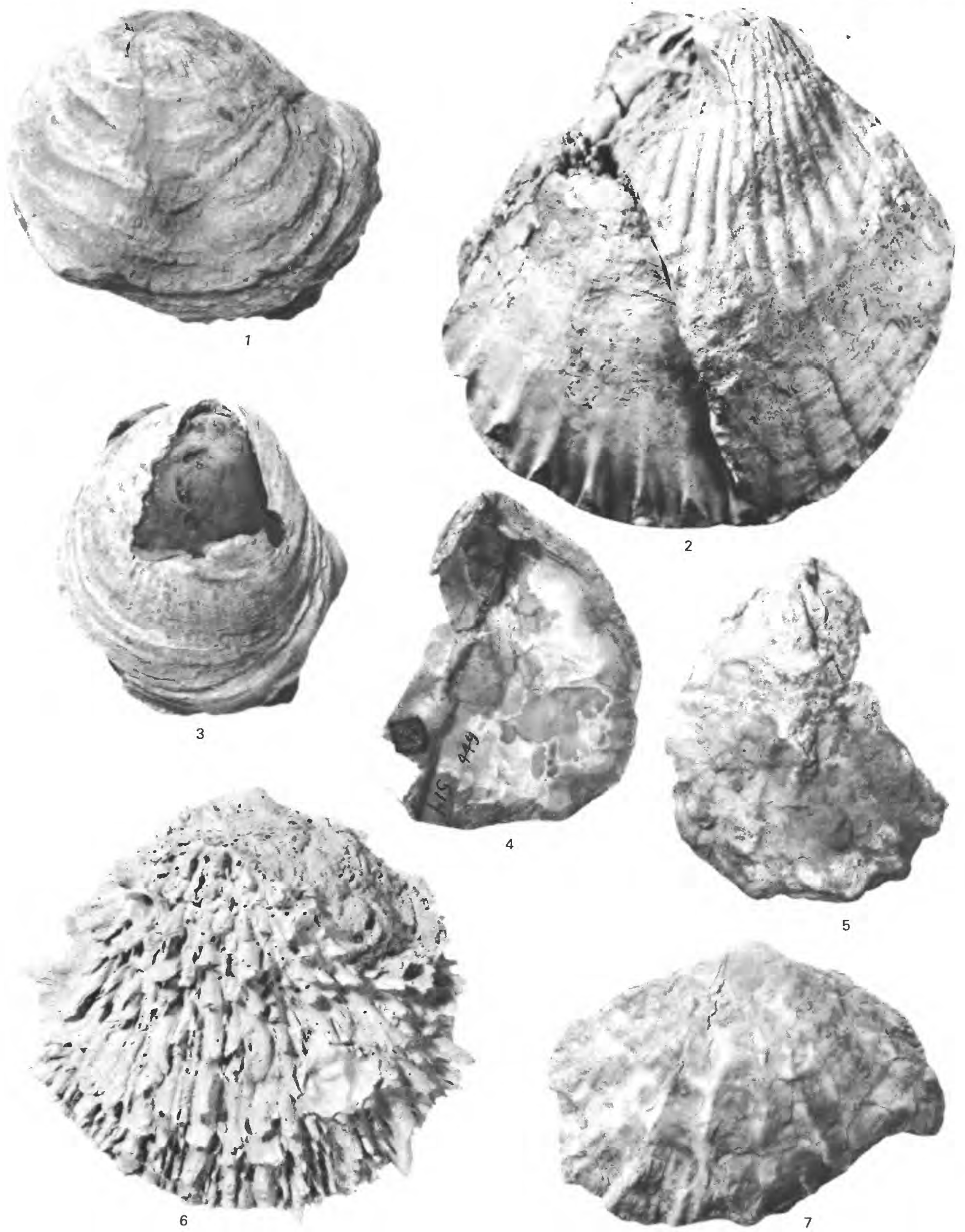

SPONDYLUS, "SPONDYLUS", ANOMIA 


\section{PLATE 6}

Figures 1, 4, 6. Anomia peruviana Orbigny (p. 11).

CAS/SU 39737. Guaymas, Sonora, Mexico, Holocene.

2. Anomia inornatus (Gabb) (p. 9).

Lectotype ANSP $4442(\times 1.5)$. Domengine Formation, California, Eocene.

3. Placunanomia granti Hertlein (p. 11).

Holotype CAS $4139(\times 2.0)$. Vaqueros Formation, California, Oligocene and Miocene.

5,11. Placunanomia californica Arnold (p. 11).

Holotype USNM 165546. Etchegoin Formation, California, Miocene and Pliocene.

7, 10,13. Anomia subcostata Conrad (p. 10).

7. Lectotype USNM 1865. Imperial Formation, California, Miocene or Pliocene.

10, 13. USNM 13345a (two specimens). Imperial Formation, California, Miocene or Pliocene.

8. Anomia inconspicua Clark (p. 10).

Holotype UCMP $11205(\times 10.0)$ [The specimen is glued to a slide and was photographed through glass. I San Ramon Sandstone, California, Miocene(?).

9, 12. Anomia vaquerosensis Loel and Corey (p. 10).

Holotype UCMP 31758. Vaqueros Formation, California, Oligocene and Miocene. 

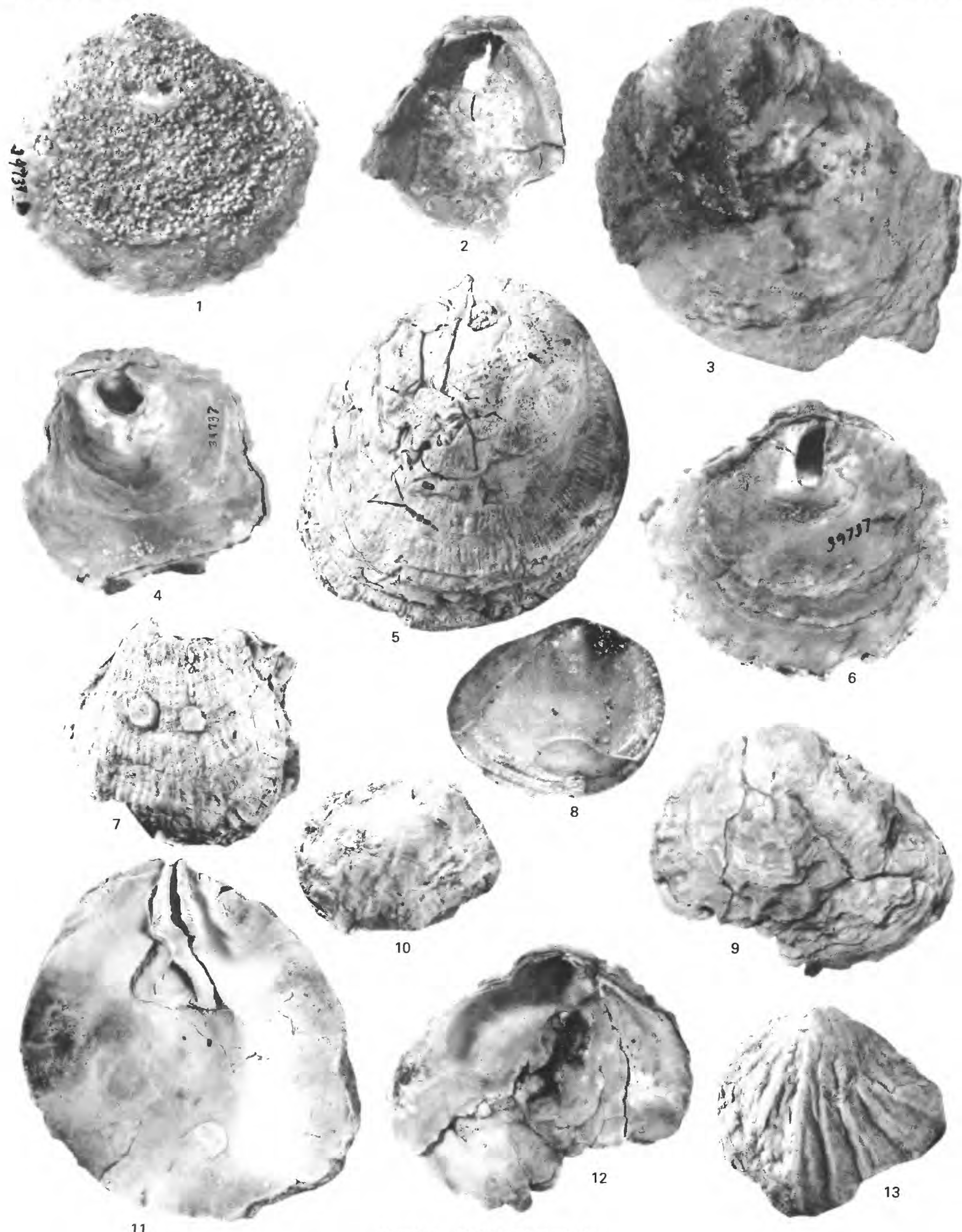


\section{PLATE 7}

Figures 1. Limaria (Limaria) hemphilli Hertlein and Strong (p. 16).

Syntype CAS 9174A ( $\times 2.0$ ). San Diego, California, Holocene.

2, 6, 7. Placunanomia hannibali Jordan and Hertlein (p. 12).

2. Paratype CAS 2111. Almejas Formation, Baja California Sur, Pliocene.

6. Holotype CAS $2110(\times 0.9)$. Almejas Formation, Baja California Sur, Pliocene.

7. Paratype CAS 2112. Almejas Formation, Baja California Sur, Pliocene.

3. Anomia inornatus (Gabb) (p. 9).

Lectotype ANSP 4442 ( $\times$ 1.5). Domengine Formation, California, Eocene.

4. Pododesmus (Monia) macroschisma Deshayes (p. 13)

Hypotype CAS 42135. McCleod Harbor, Montague Island, Alaska, Holocene.

5. Anomia subcostata (Conrad) (p. 10).

Hypotype CAS 1814 ( $\times$ 1.5; G D. Hanna, 1926a, pl. 23, fig. 4). Imperial Formation, California, Miocene or Pliocene. 


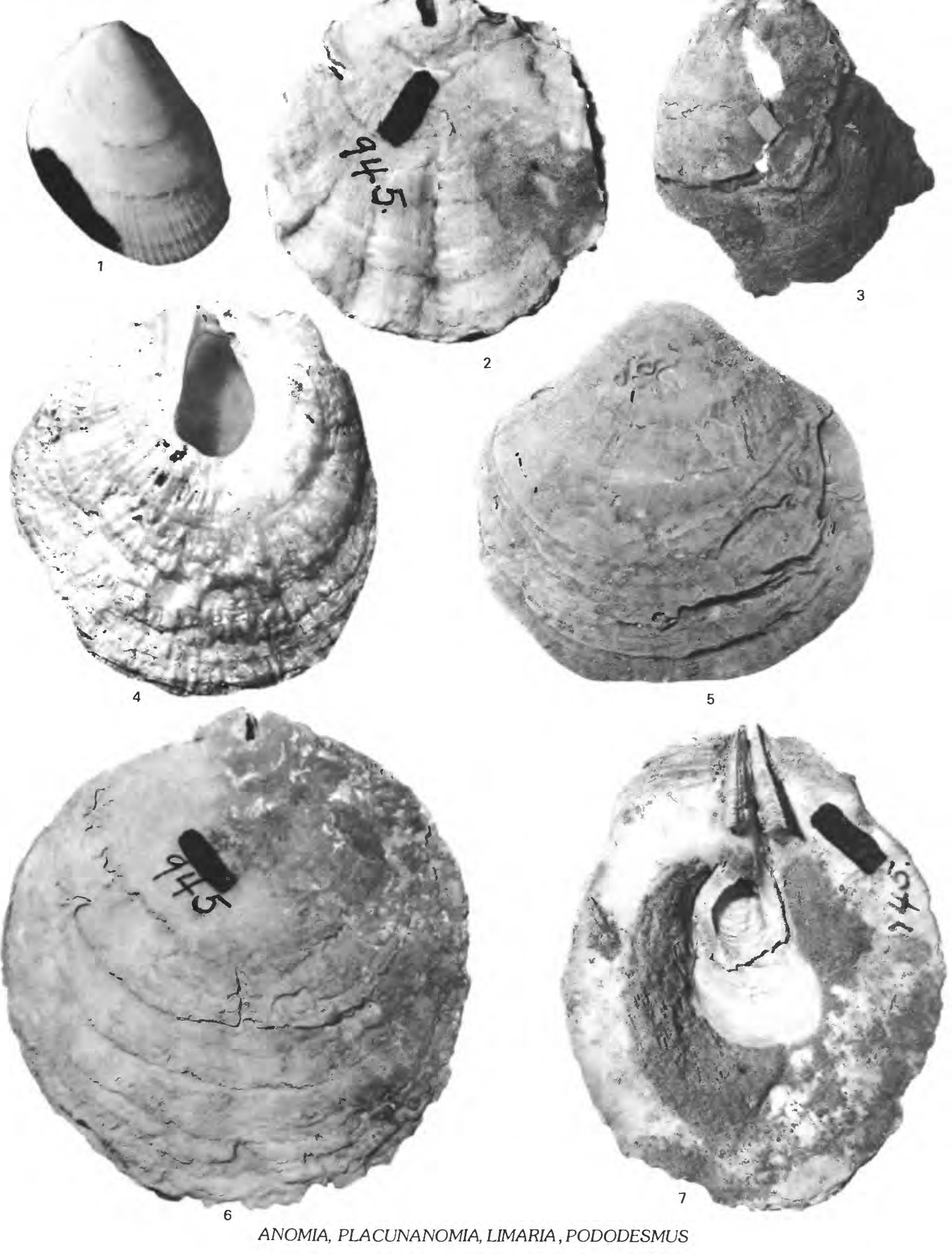




\section{PLATE 8}

Figures 1. Anomia subcostata Conrad (p. 10).

Hypotype CAS 1814 ( $\times 1.5$; G D. Hanna, 1926a, pl. 23, fig. 4). Imperial Formation, California, Miocene or Pliocene.

2, 5. Placunanomia hannibali Jordan and Hertlein (p. 12).

2. Paratype CAS 2111. Almejas Formation, Baja California Norte, Pliocene.

5. Paratype CAS 2112. Almejas Formation, Baja California Norte, Pliocene.

3, 6, 8. Limaria (Limaria) hemphilli Hertlein and Strong (p. 16).

3. Syntype CAS 9174 ( × 1.5). San Diego, California, Holocene.

6, 8. Syntype CAS 9174A ( $\times 1.5$ ). San Diego, California, Holocene.

4, 7. Pododesmus (Monia) macroschisma Deshayes (p. 13)

Hypotype CAS 42135. McCleod Harbor, Montague Island, Alaska, Holocene. 

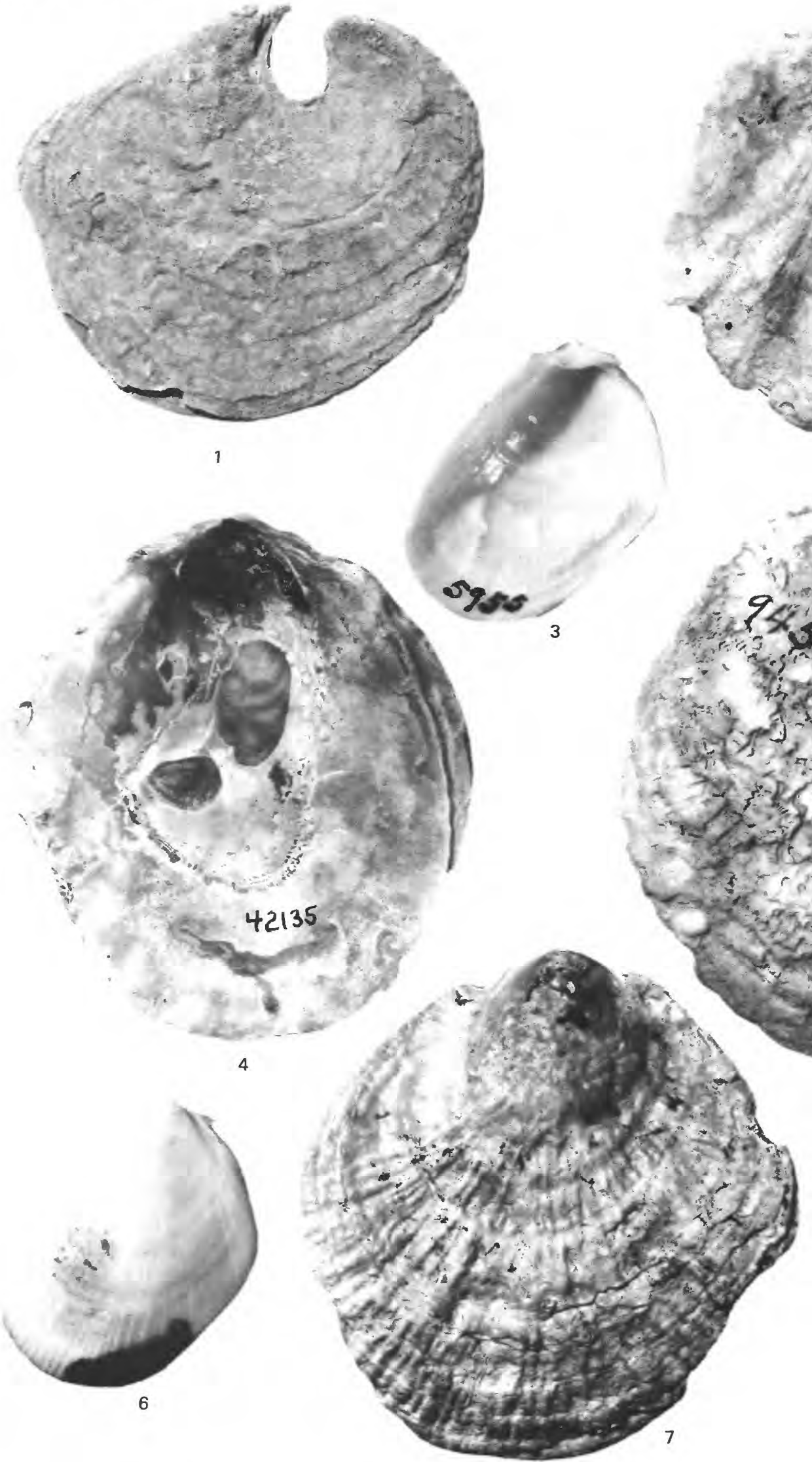

ANOMIA, PLACUNANOMIA, LIMARIA, PODODESMUS

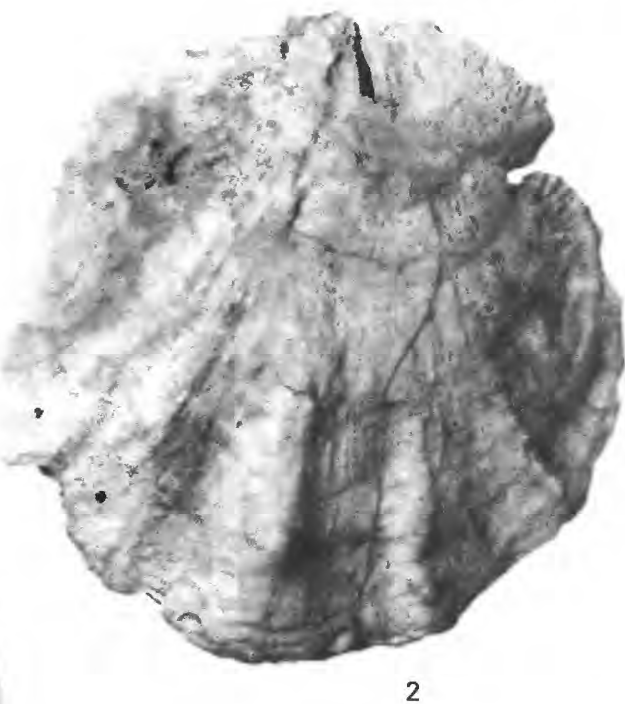




\section{PLATE 9}

Figures 1. Spondylus perrini Wiedey (p. 7).

Holotype of Spondylus inezana Wiedey SDNM 29. Vaqueros Formation, California, Oligocene and Miocene.

2. Limatula aff. L. subauriculata (Montagu) (p. 17).

Hypotype USNM 496096 ( $\times$ 4.0; Woodring, 1938, pl. 8, fig. 6). Fernando Formation, California, Pliocene.

3, 9. Spondylus bostrychites Guppy (p. 8).

3. Lectotype BM(NH) R12833 (photograph copied from Palmer, 1938, pl. 3, fig. 4).

9. Paratype BM(NH) (photograph copied from Palmer, 1938, pl. 2, fig. 1).

4-6, 8. Limaria (Limaria) orcutti Hertlein and Grant (p. 16).

4, 8. Holotype LAM 4509 ( $\times$ 0.7). San Diego Formation, California, Pliocene.

5, 6. Paratype LAM 4511 ( $\times$ 0.7). San Diego Formation, California, Pliocene.

7. Pododesmus (Monia) macroschisma (Deshayes) (p. 13).

Hypotype USNM 165602 (Arnold, 1909 [1910], pl. 14, fig. 1). Etchegoin Formation, California, Miocene and Pliocene.

10. Acesta (Plicacesta) haseltinei (Dickerson) (p. 15).

Holotype of Lima perrini Waring CAS/SU 303 ( $\times$ 0.7). Martinez Formation, California, Paleocene. 
GEOLOGICAL SURVEY
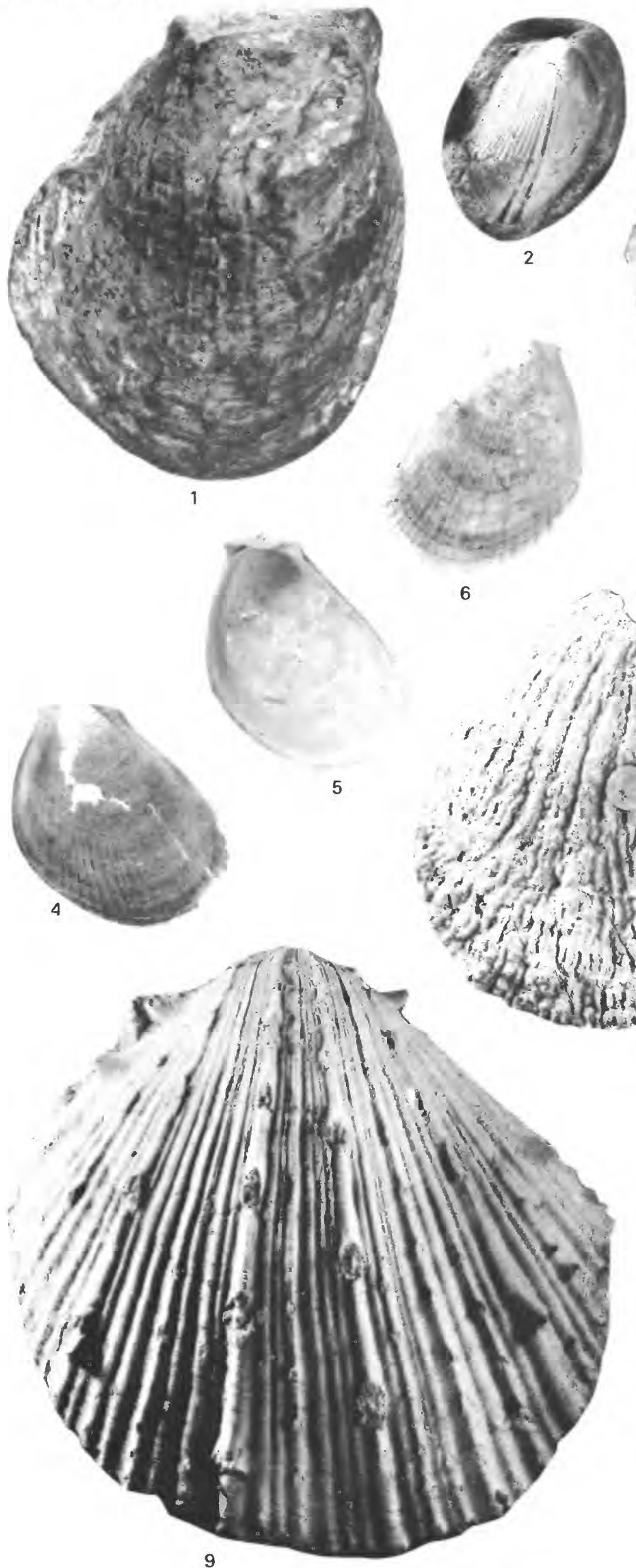
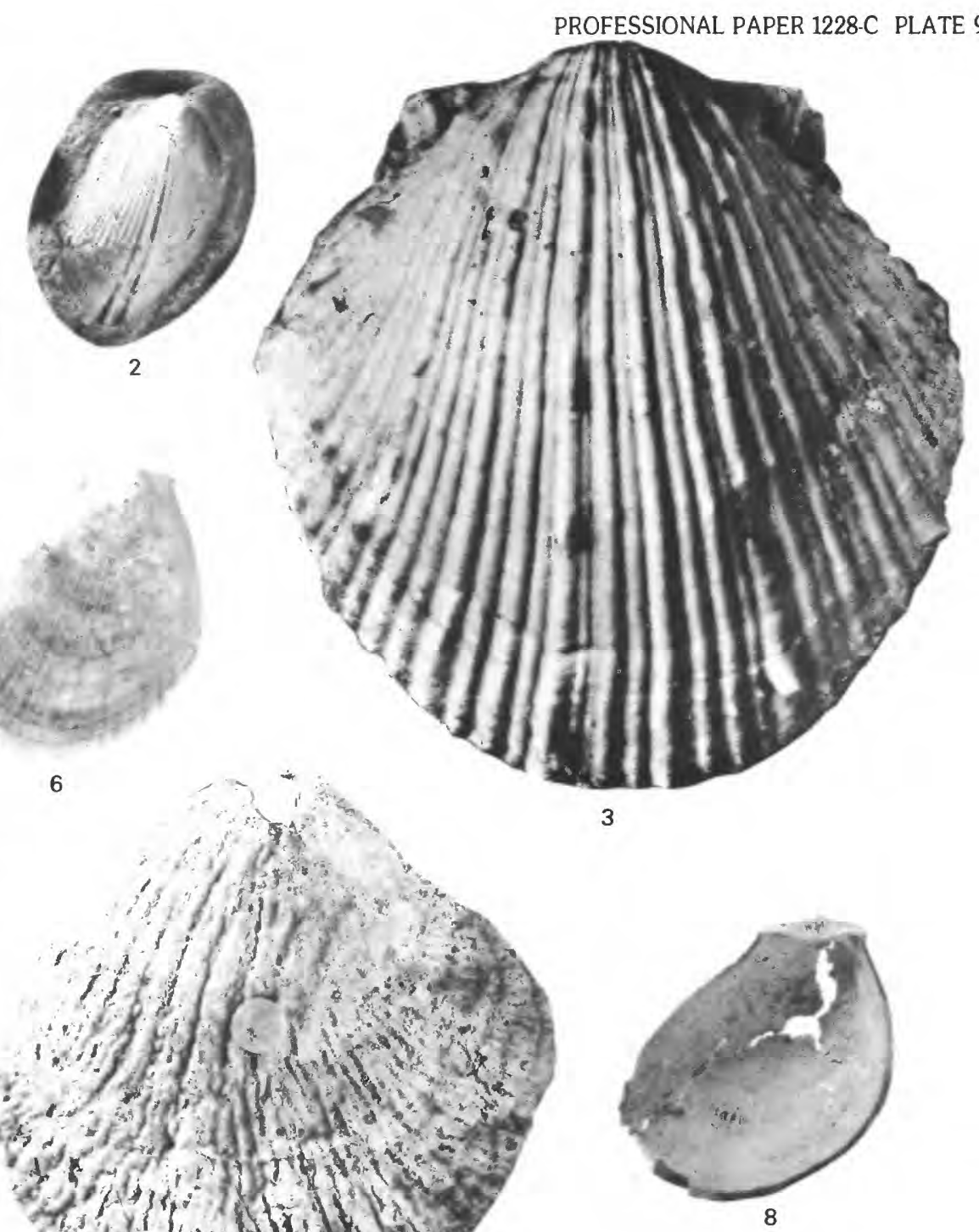

Nint
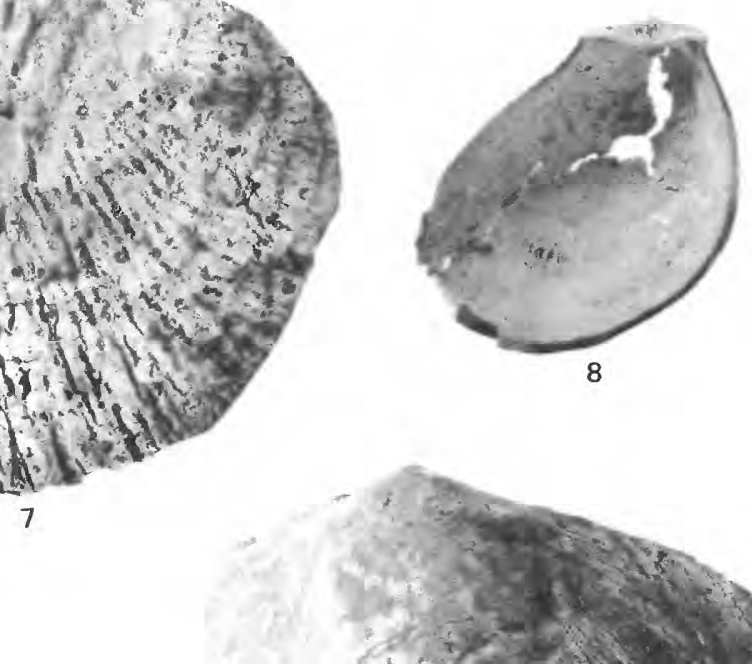


\section{PLATE 10}

Figures 1, 3. Lima (Lima) vedderi Moore (p. 13).

Holotype USNM 240060. Monterey Shale, California, Miocene.

1. $(\times 1.5)$.

3. $(\times 3.0)$.

2, 9. Limea? (Isolimea?) claytonensis (Dickerson) (p. 17).

2. Syntype UCMP 11721 ( $\times 10.0$ ). Martinez Formation, California, Paleocene.

9. Syntype UCMP $11720(\times 10.0)$. Martinez Formation, California, Paleocene.

4, 7. Acesta (Acesta) hamlini (Dall) (p. 15).

Holotype USNM 495186. Fernando Formation, California, Pliocene.

5, 8. Acesta (Acesta) multiradiata (Gabb) (p. 14).

5. Latex impression of hypotype USNM 157826 (Stanton, 1896, pl. 63, fig. 7). Tejon Formation, California, Eocene.

8. Holotype (photograph copied from Gabb, 1869, pl. 33, fig. 101). Martinez Formation, California, Paleocene.

6. Limaria (Limaria) clarki (Nelson) (p. 16).

Holotype UCMP 30494 ( $\times$ 3.0). Martinez Formation, California, Paleocene.

10,11. Acesta (Plicacesta) haseltinei (Dickerson) (p. 15).

10. Holotype of Lima perrini Waring CAS/SU 303 ( $\times 0.5)$. Martinez Formation, California, Paleocene.

11. Holotype UCMP 11676 ( $\times$ 0.7). Martinez Formation, California, Paleocene. 


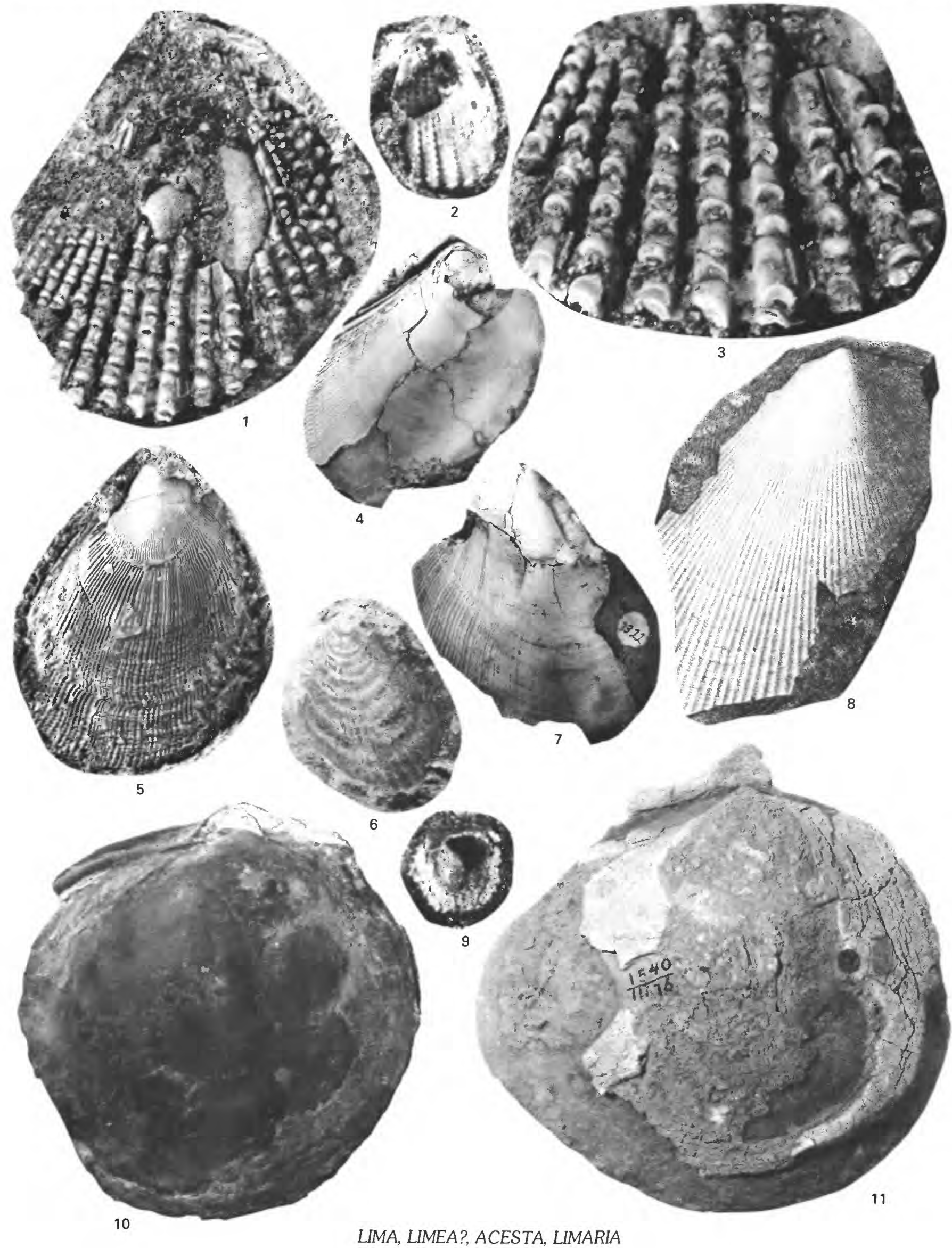




\section{PLATE 11}

Figures 1, 3, 4, 6. Pycnodonte (Pycnodonte) ynezana (Loel and Corey) (p. 18). Holotype UCMP 31745. Figures 4, 6 ( $\times 0.9$ ). Vaqueros Formation, California, Oligocene and Miocene.

2, 5. Dendostrea? vespertina (Conrad) (p. 25).

Paratype ANSP 13366e ( $\times$ 1.5). Imperial Formation, California, Miocene or Pliocene. 


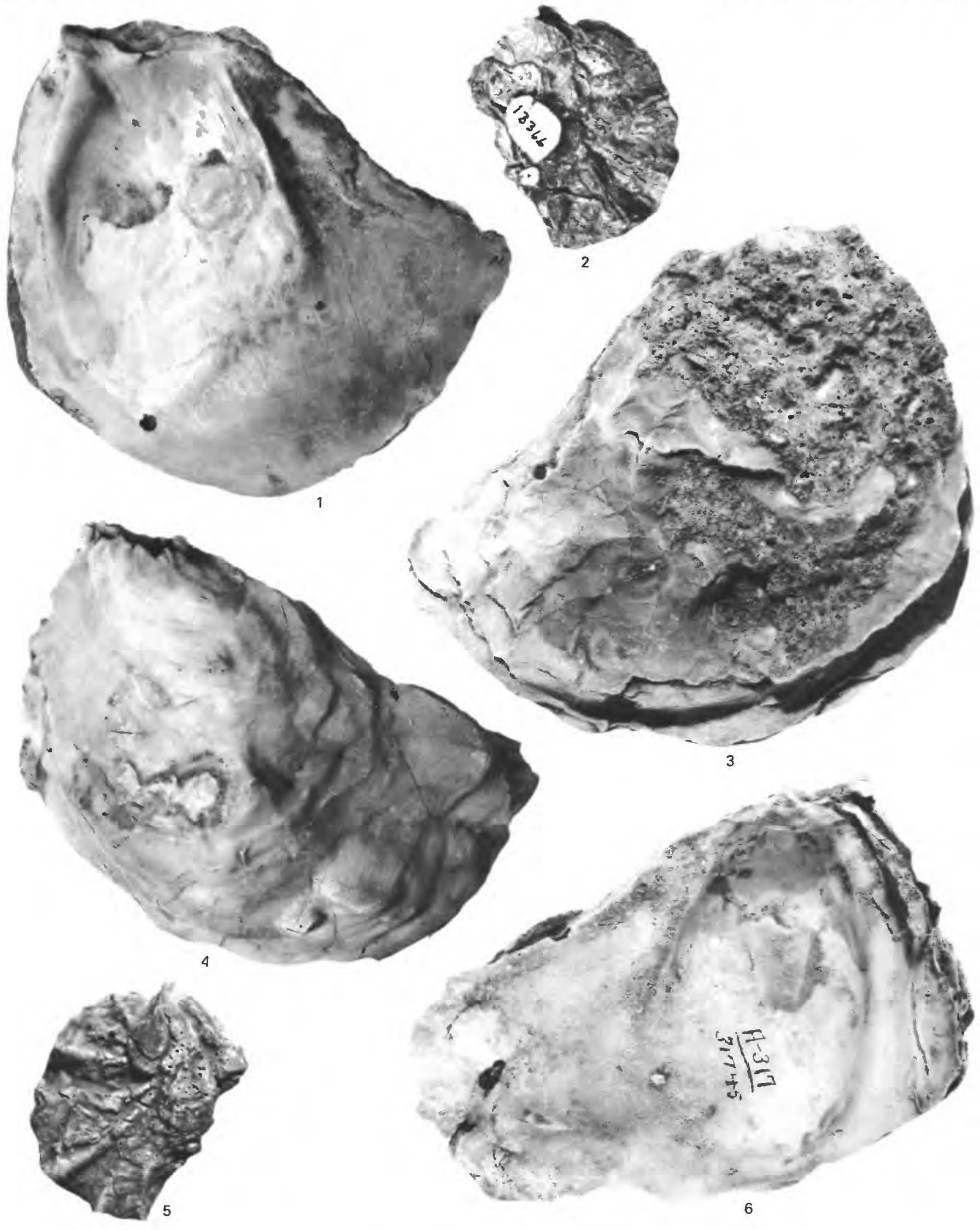

PYCNODONTE, DENDOSTREA? 


\section{PLATE 12}

Figures 1, 4, 7, 8. Pycnodonte (Pycnodonte) erici (Hertlein) (p. 19).

Holotype CAS 2094. Almejas Formation, Baja California Sur, Pliocene.

3. Striostrea? appressa (Gabb) (p. 33).

Paratype (photograph copied from Gabb, 1869, pl. 34, fig. 104a).

Temblor(?) Formation, California, Oligocene and Miocene.

2, 5, 6. Dendostrea? vespertina (Conrad) (p. 25).

2. Paratype ANSP $13366 \mathrm{~d}$ ( $\times$ 1.5). Imperial Formation, California, Miocene or Pliocene.

5, 6. Paratype ANSP 13366a $(\times 1.5)$. Imperial Formation, California, Miocene or Pliocene. 

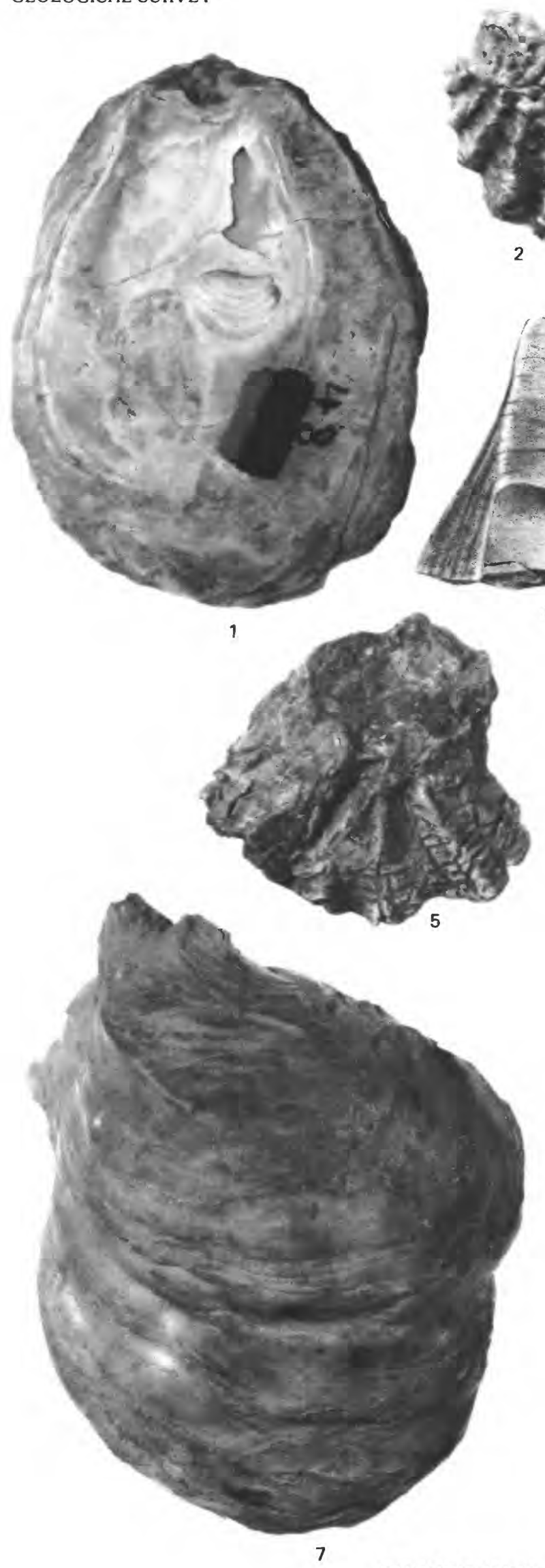

PYCNODONTE, DENDOSTREA?, STRIOSTREA?
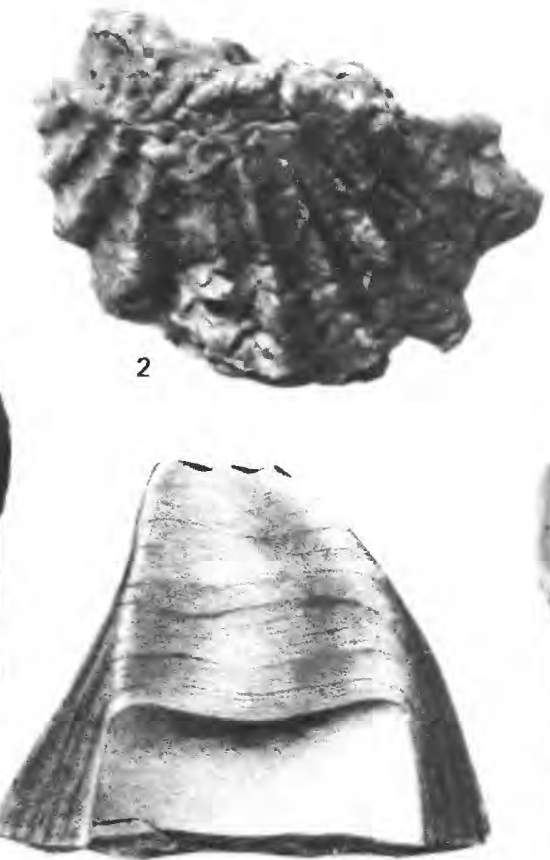

3

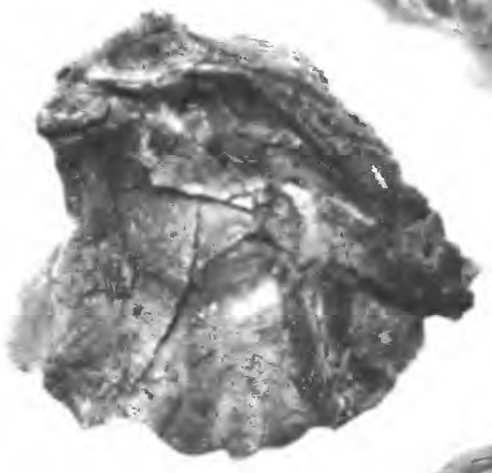

$\hat{k}^{2} \mathrm{y}^{3}$ 


\section{PLATE 13}

Figures 1, 4, 6, 7. Pycnodonte? (Pycnodonte?) heermanni (Conrad) (p. 21).

Syntypes ANSP 13367 (6, 7 x 0.7). Imperial Formation, California, Miocene or Pliocene.

2, 3. Acutostrea idriaensis idriaensis (Gabb) (p. 31).

Photograph copied from Gabb (1869, pl. 33, figs. 103b, 103c), Domengine Formation, California, Eocene.

5. Dendostrea? vespertina (Conrad) (p. 25).

Paratype ANSP 13366a ( $\times$ 1.5). Imperial Formation, California, Miocene or Pliocene. 


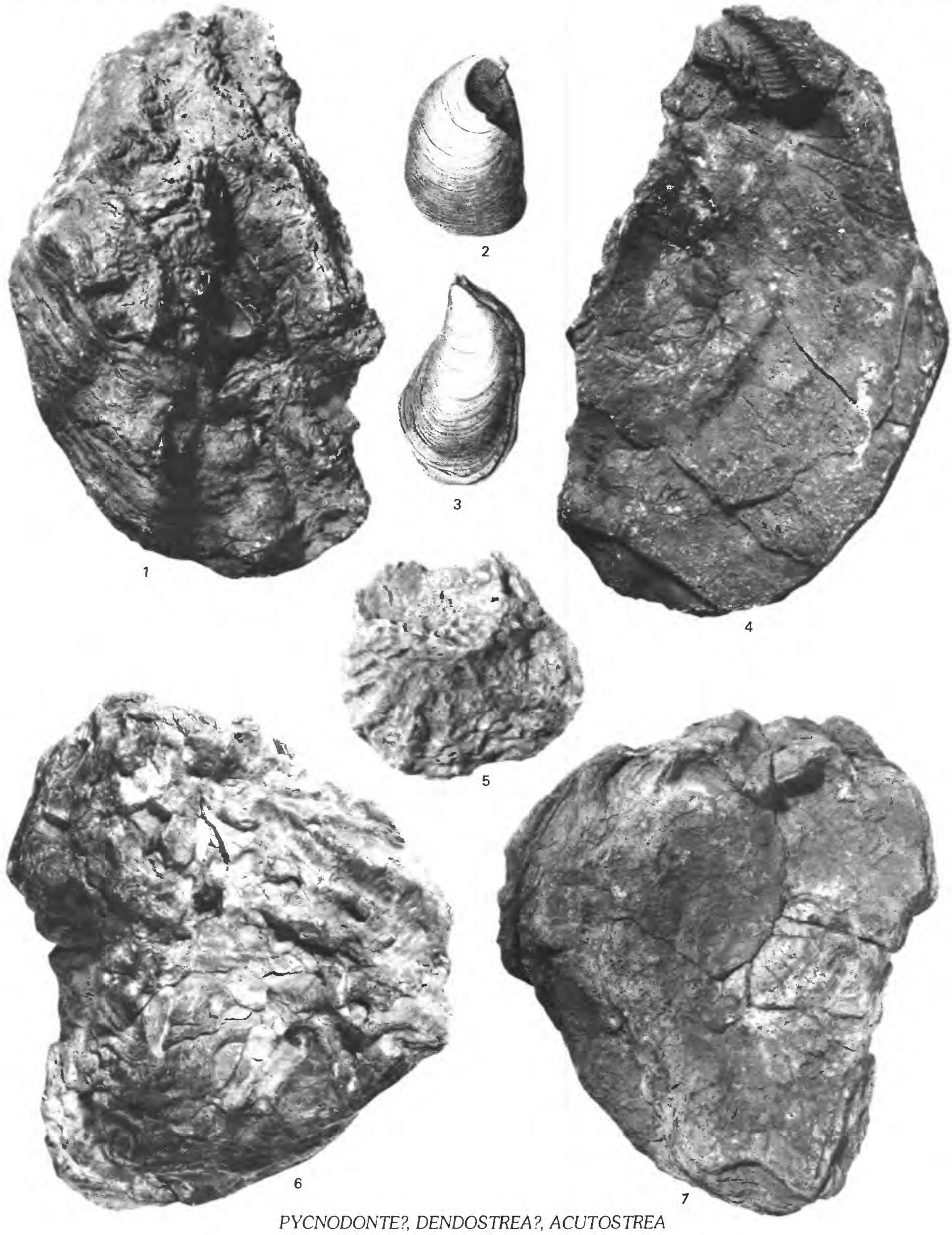




\section{PLATE 14}

Figures 1, 3, 5, 7. Pycnodonte? (Pycnodonte?) howelli (Wiedey) (p. 20).

1,5. Syntype CAS 2981. Vaqueros Formation, California, Oligocene and Miocene.

3, 7. Syntype CAS $2982(\times 0.8)$. Vaqueros Formation, California, Oligocene and Miocene.

2. Dendostrea? vespertina (Conrad) (p. 25).

Hypotype of G D. Hanna (1926a, pl. 26, figs. 1-3) UCMP 33290. Imperial Formation, California, Miocene or Pliocene.

4. Pycnodonte? (Pycnodonte?) heermanni (Conrad) (p. 21).

Syntype ANSP 13367. Imperial Formation, California, Miocene or Pliocene.

6. Acutostrea idriaensis idriaensis (Gabb) (p. 31).

Photograph copied from Gabb (1869, pl. 33, fig. 103d). Domengine Formation, California, Eocene. 


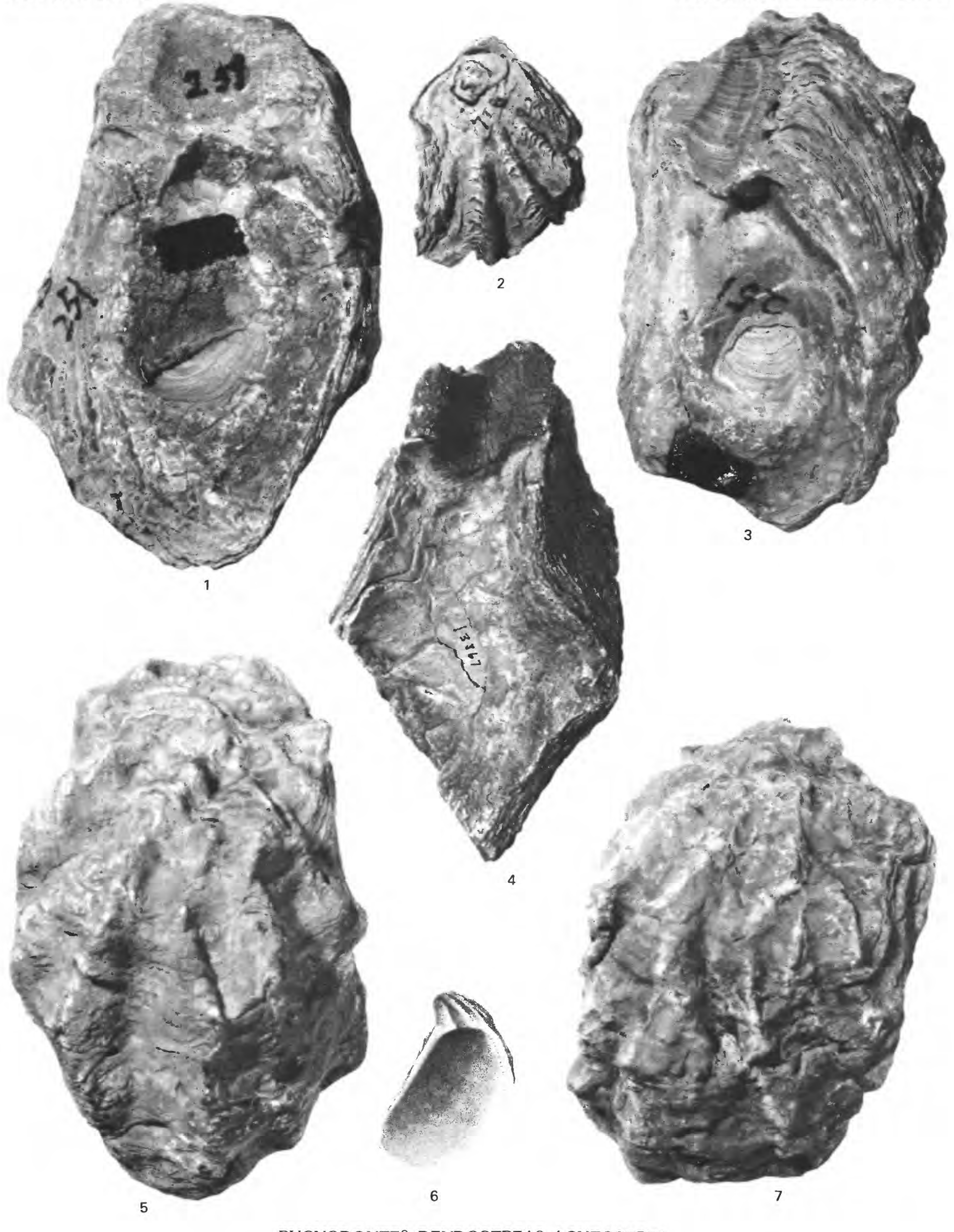

PYCNODONTE?, DENDOSTREA?, ACUTOSTREA 
PLATE 15

Figures 1, 4, 5, 8. Pycnodonte? (Pycnodonte?) wiedeyi (Hertlein) (p. 20).

1,4. Paratype CAS 4130. Vaqueros Formation, California, Oligocene and Miocene.

5, 8. Holotype CAS $4129(\times 0.8$ ). Vaqueros Formation, California, Oligocene and Miocene.

2, 3, 6, 7. Dendostrea? vespertina (Conrad) (p. 25).

2, 3. Syntypes of Ostrea vespertina sequens Arnold USNM 165545 (two specimens). San Joaquin Formation, California, Pliocene.

6. Paratype ANSP 13366a ( $\times$ 1.5). Imperial Formation, California, Miocene or Pliocene.

7. Hypotype of G D. Hanna (1926a, pl. 26, figs. 1-3). UCMP 32290. Imperial Formation, California, Miocene or Pliocene. 


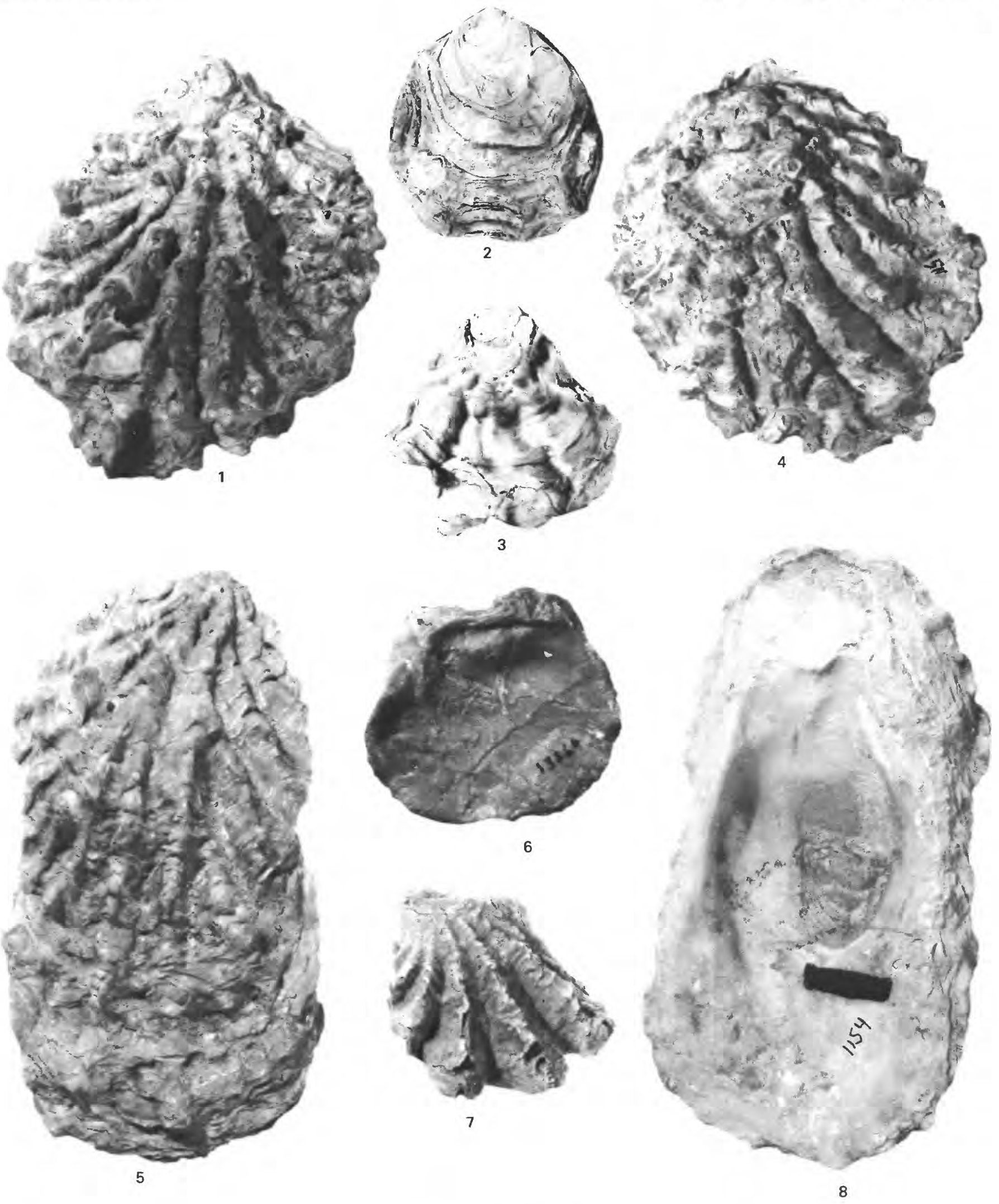

PYCNODONTE?, DENDOSTREA? 


\section{PLATE 16}

Figures 1, 2. Hyotissa hyotis (Linne)) (p. 22).

Hypotype of Durham (1950, pl. 6, figs. 1, 4) UCMP $15502(\times 0.7)$.

Unnamed Pleistocene strata, Isla Carmen, Baja California Sur.

3. Acutostrea idriaensis idriaensis (Gabb) (p. 31).

Photograph copied from Gabb (1869, pl. 34, fig. 103). Domengine

Formation, California, Eocene.

4. Pycnodonte? (Pycnodonte?) heermanii (Conrad) (p. 21).

Syntype ANSP 13367b. Imperial Formation, California, Miocene or Pliocene.

5. Striostrea? appressa (Gabb) (p. 33).

Photograph copied from Gabb (1869, pl. 34, fig. 104). Temblor(?)

Formation, California, Oligocene and Miocene.

6, 7. Dendostrea? vespertina (Conrad) (p. 25).

Lectotype of Woodring (1938) ANSP 13366. Imperial Formation, California, Miocene or Pliocene. 

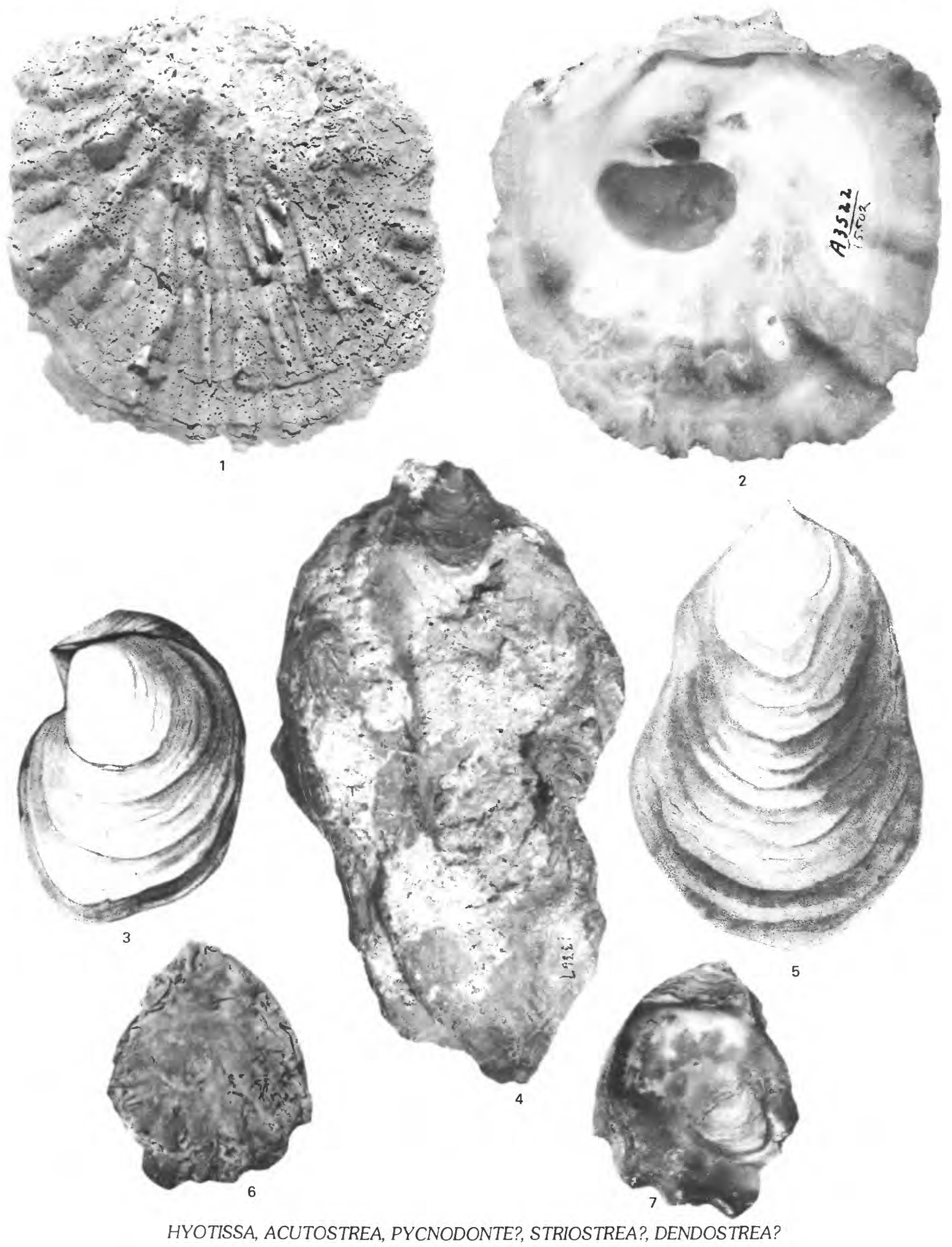


\section{PLATE 17}

Figures 1-5. Lopha? ("Lopha”) veatchii Gabb (p. 24)

1, 3, 5. Paratypes ANSP unnumbered. Almejas Formation, Baja California Norte, Pliocene.

2, 4. Holotype ANSP 4502. Almejas Formation, Baja California Norte, Pliocene.

6, 7. Pycnodonte? (Pycnodonte?) heermanni (Conrad) (p. 21)

Hypotype of Ostrea veatchii Gabb (1869, pl. 17, figs. 21, 21a), ANSP unnumbered $(\times 0.8$ ). Almejas(?) Formation, Baja California Sur, Pliocene. 

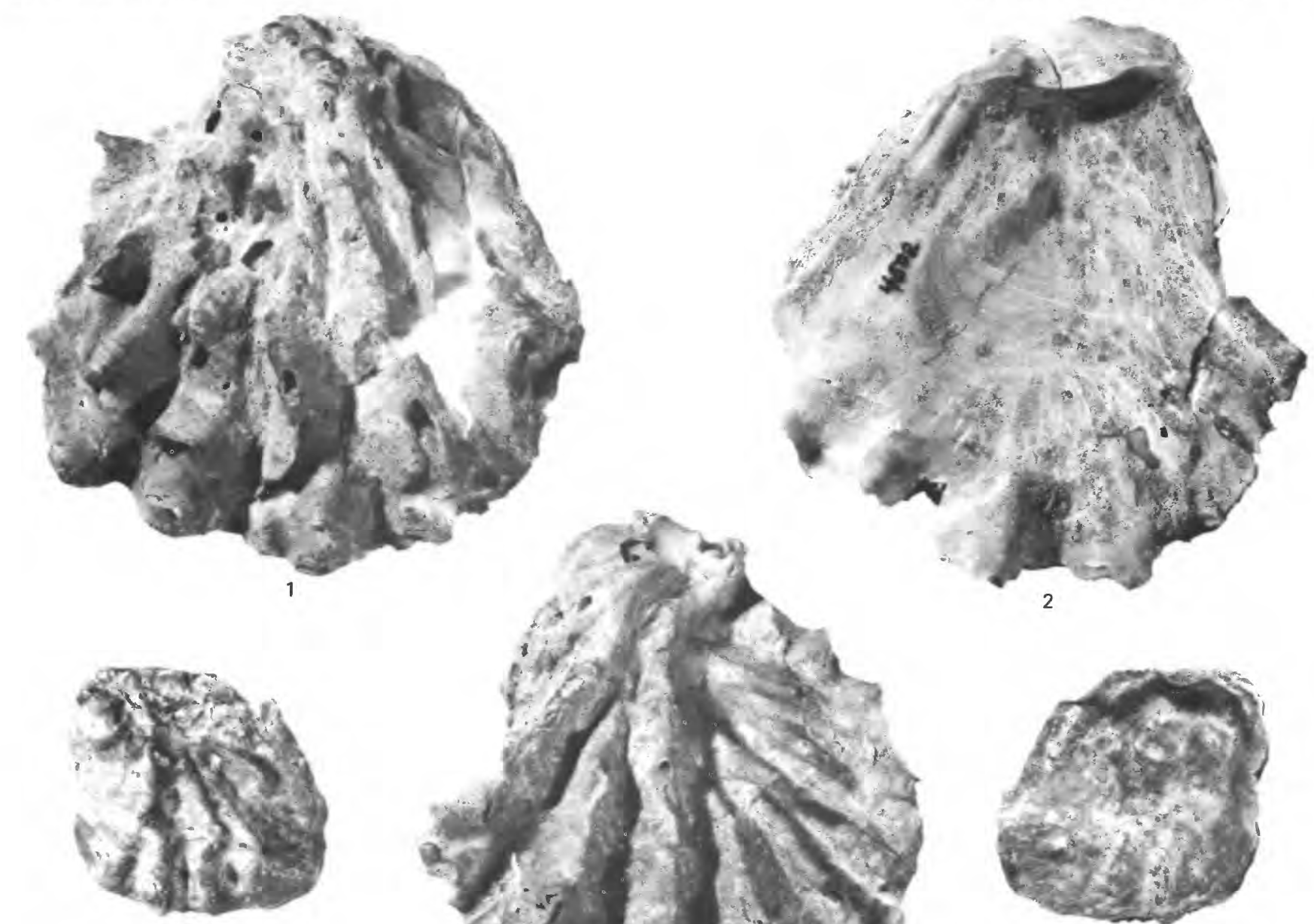

3

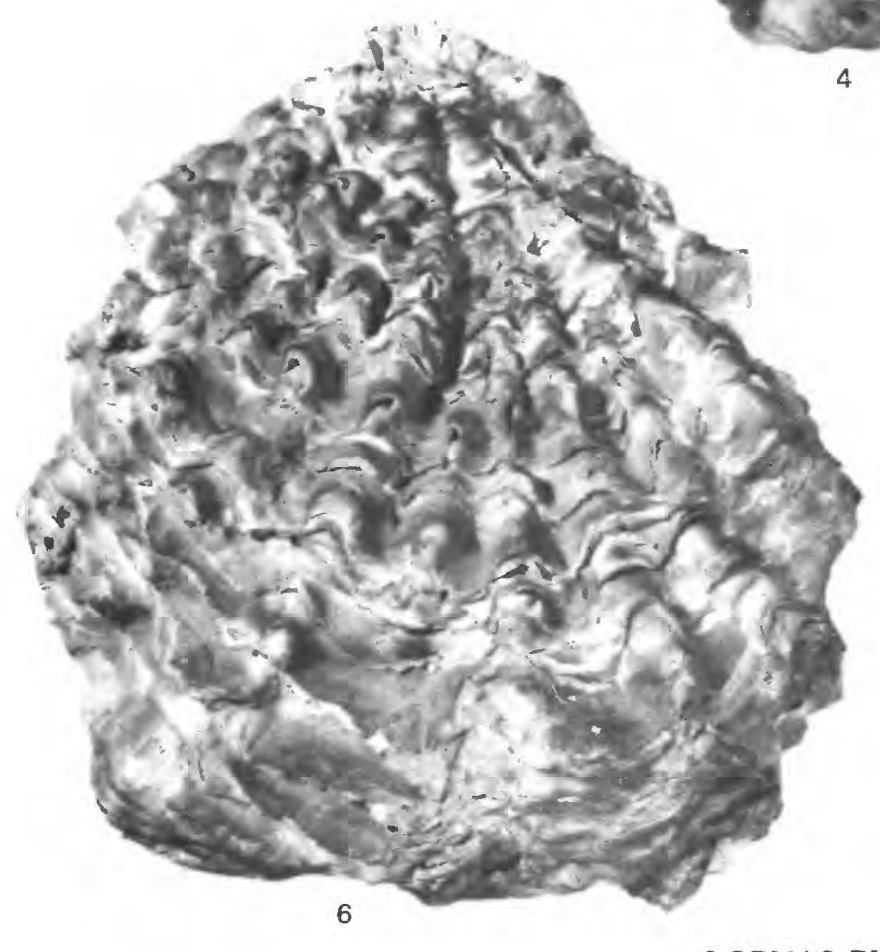

LOPHA?, PYCNODONTE?
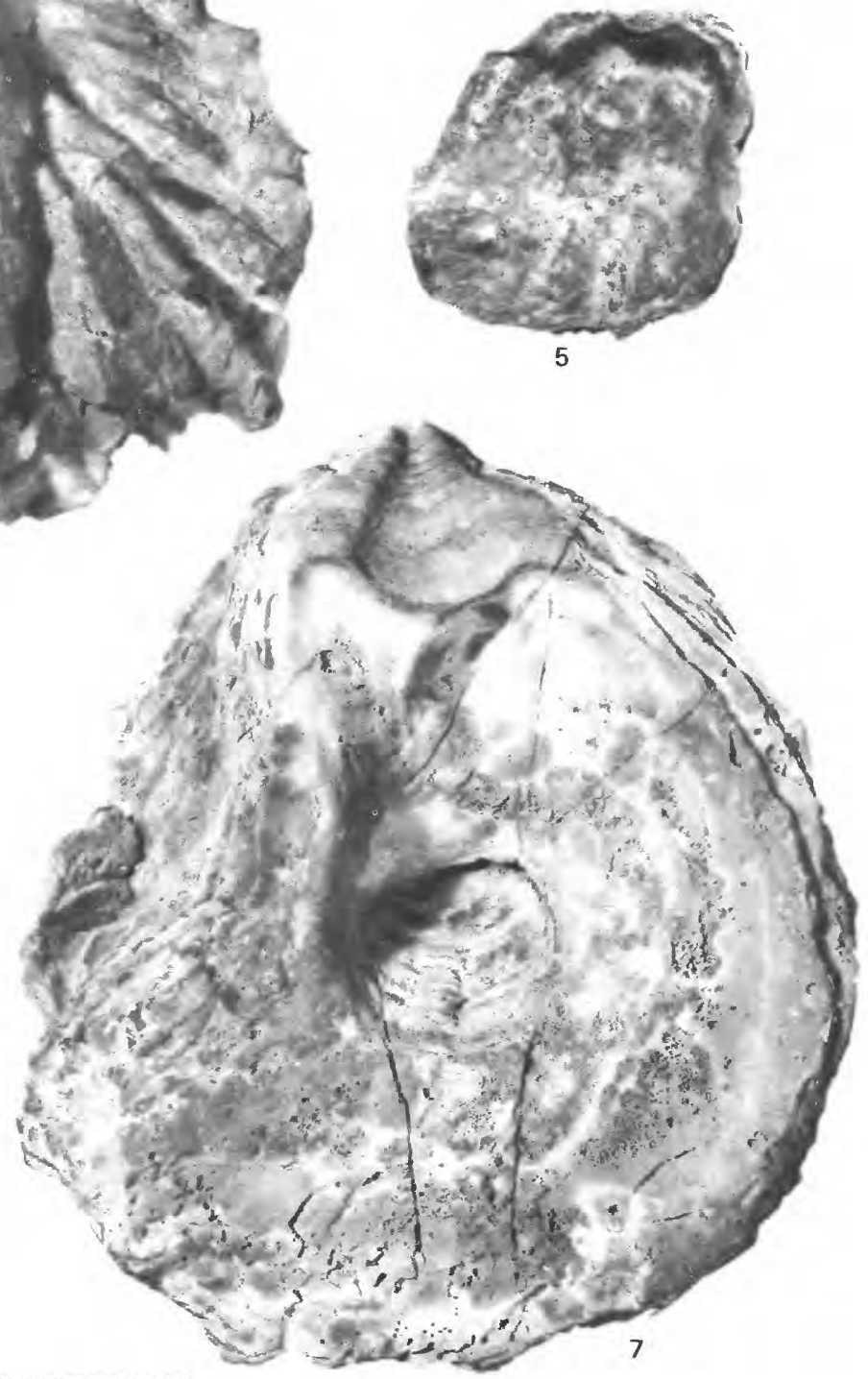


\section{PLATE 18}

Figures 1-6. Saccostrea palmula (Carpenter) (p. 32).

Espiritu Santo, Golfo de California, Holocene.

1, 5. CAS 057756.

2, 3. CAS 057757

4. CAS 057758 .

6. CAS 057759

7, 8. Pycnodonte? (Pycnodonte?) loeli (Hertlein) (p. 21).

Holotype CAS 4117 ( $\times 0.8$ ). Vaqueros Formation, California, Oligocene and Miocene. 

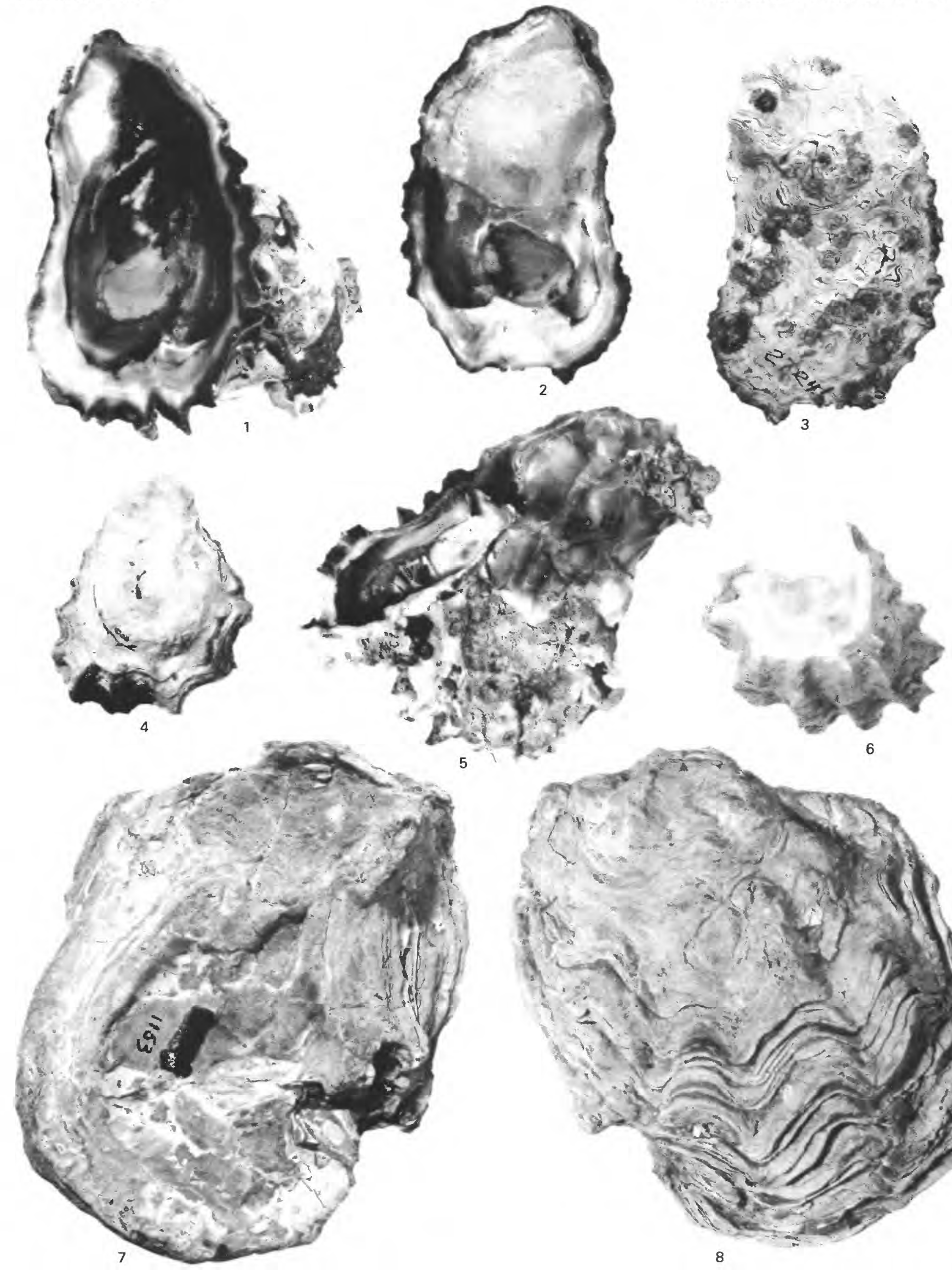

SACCOSTREA, PYCNODONTE? 


\section{PLATE 19}

Figures 1, 2, 6. Gryphaeostrea aviculiformis (Anderson) (p. 18).

Holotype CAS 21 ( $\times 2.0$ ). Domengine Formation, California, Eocene. 3, 5. Crassostrea? ashleyi (Hertlein) (p. 38).

3. Holotype of Ostrea arnoldi Adegoke UCMP 36646. Temblor Formation, California, Oligocene and Miocene.

5. Paratype of Ostrea arnoldi Adegoke UCMP 36647. Temblor Formation, California, Oligocene and Miocene.

4, 7, 8. Pycnodonte? (Crenostrea?) stewarti (M. A. Hanna) (p. 22).

4. Syntype UCMP $30921(\times 0.8)$. Rose Canyon Shale, California, Eocene.

7, 8. Syntype UCMP $30922(\times 0.8)$. Rose Canyon Shale, California, Eocene. 


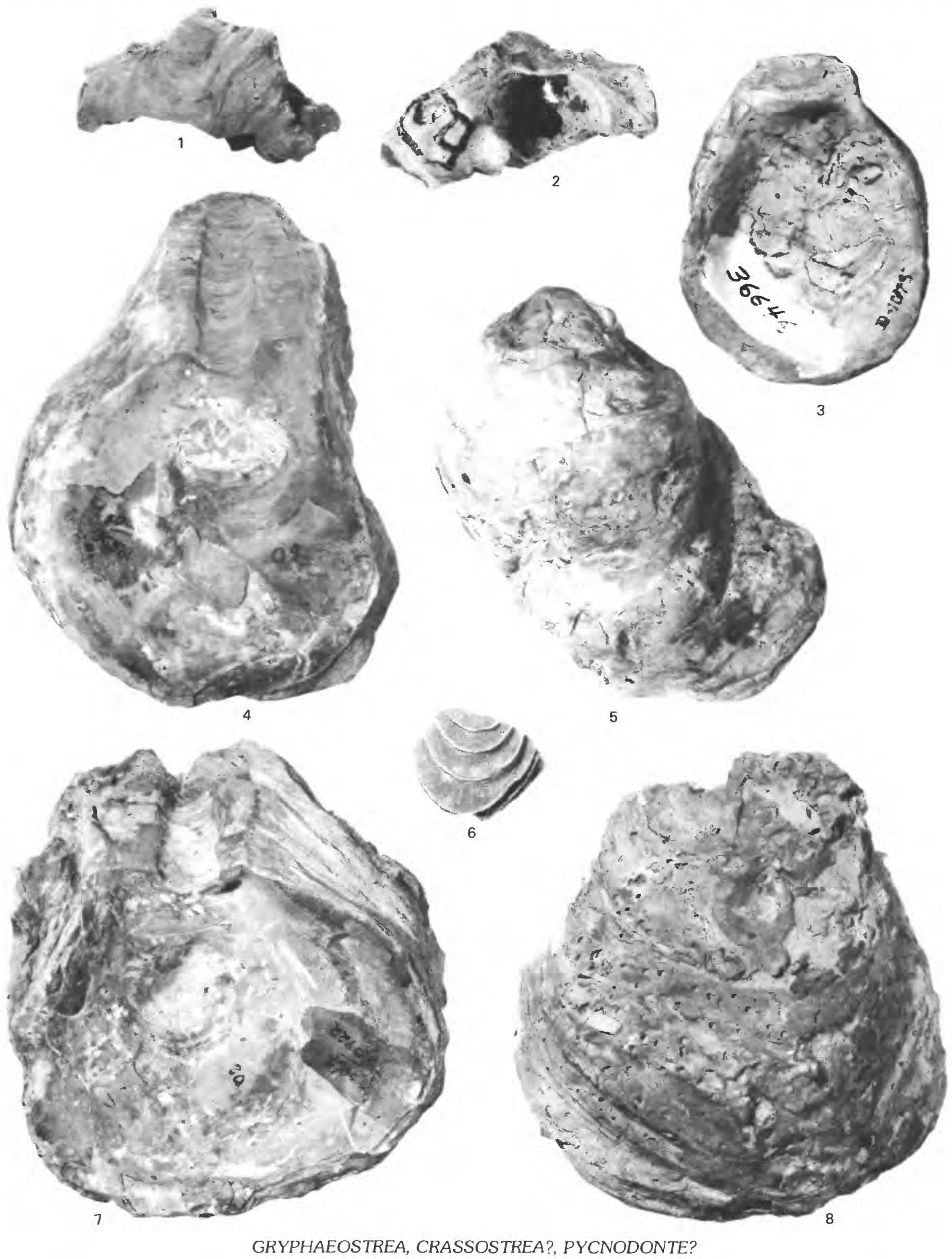




\section{PLATE 20}

Figures 1. Crassostrea? englekyi (Hertlein) (p. 38).

Holotype CAS $4116(\times 0.7)$. Vaqueros Formation, California, Oligocene and Miocene.

2-6. Crassostrea? ashleyi (Hertlein) (p. 38).

2. Holotype of Ostrea arnoldi Adegoke UCMP 36646. Temblor Formation, California, Oligocene and Miocene.

3. Paratype of Ostrea arnoldi Adegoke UCMP 36647. Temblor Formation, California, Oligocene and Miocene.

4, 5. Holotype CAS 6065 ( $\times 0.5$ ). Temblor Formation, California, Oligocene and Miocene.

6. Holotype of Ostrea hertleini Adegoke UCMP 36654. Temblor Formation, California, Oligocene and Miocene. 

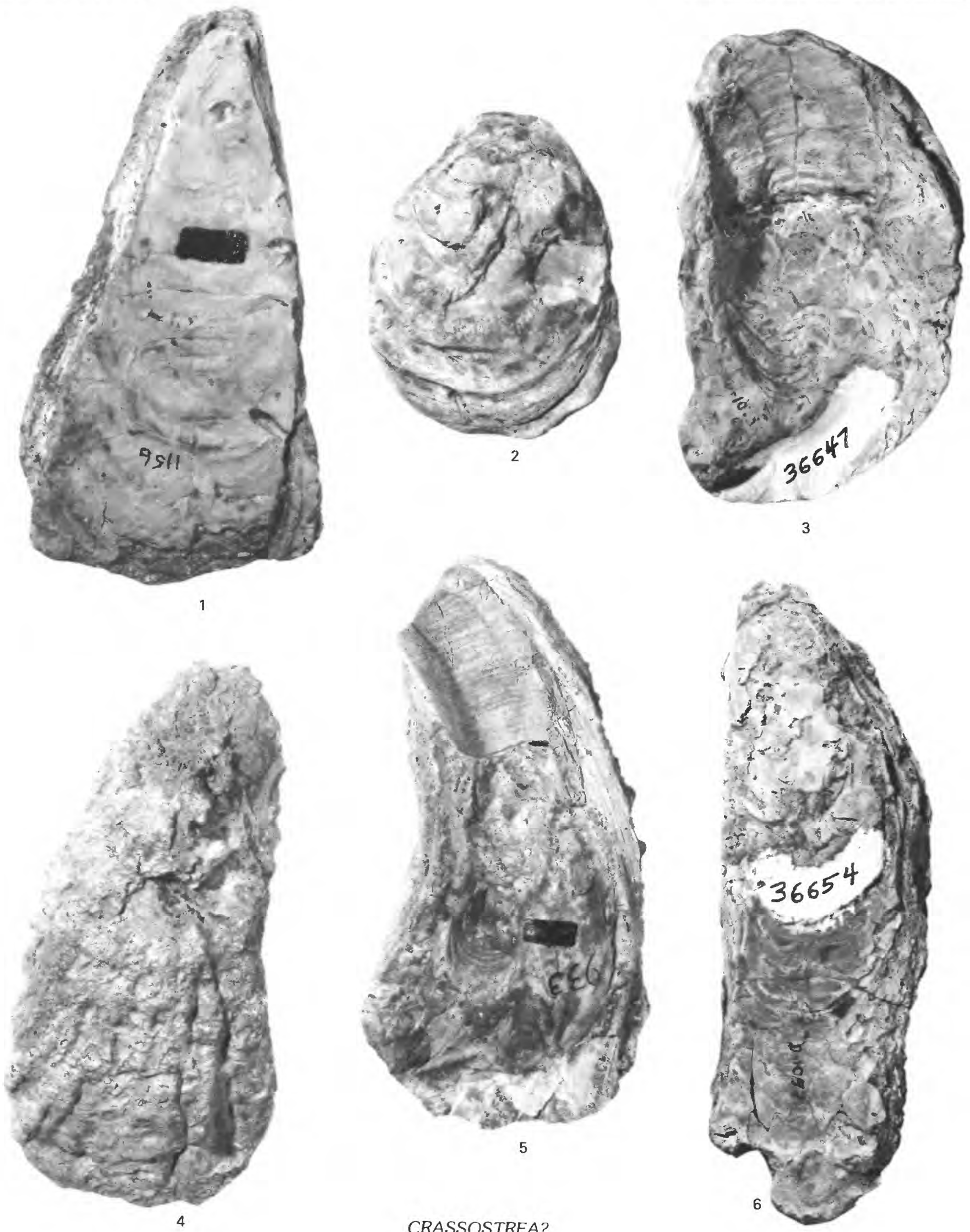

3

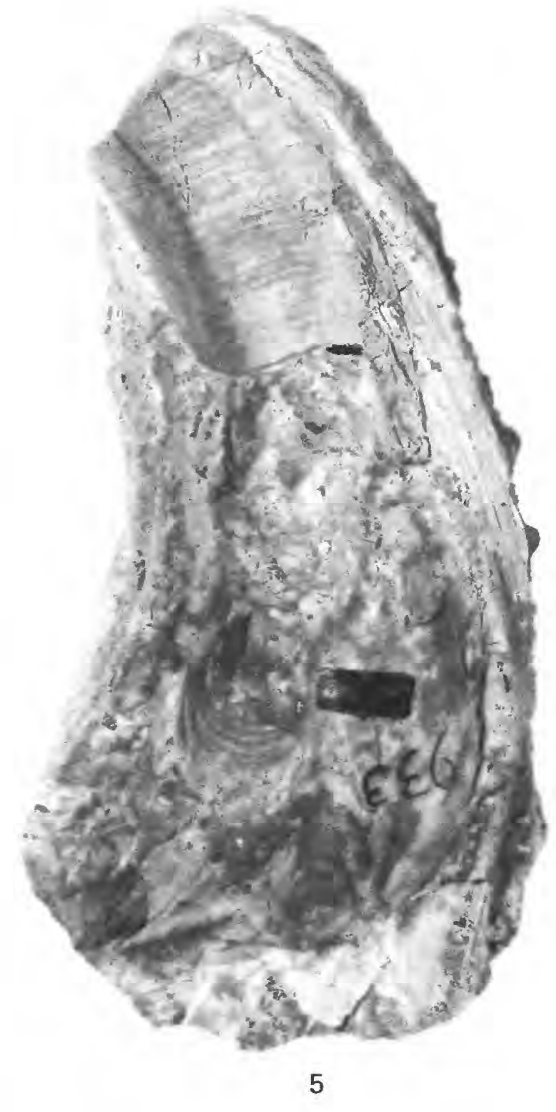

CRASSOSTREA?

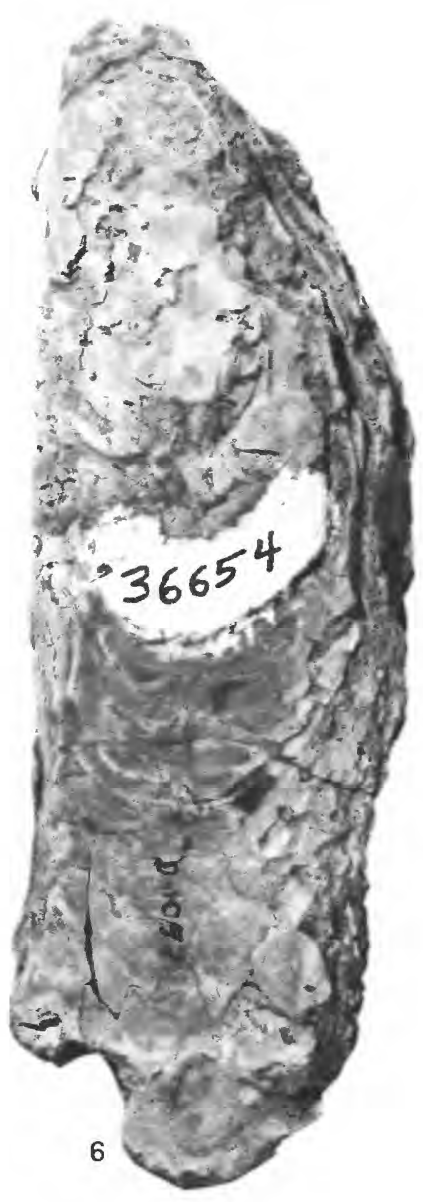




\section{PLATE 21}

Figures 1, 4. Pycnodonte? (Crenostrea?) eldridgei (Arnold) (p. 22).

Holotype USNM 164966. Vaqueros Formation, California, Oligocene and Miocene.

2. Crassostrea? vaquerosensis (Loel and Corey) (p. 38).

Paratype CAS 6790. Vaqueros Formation, California, Oligocene and Miocene.

3. Crassostrea? ashleyi (Hertlein) (p. 38).

Holotype of Ostrea altatemblorensis Grant and Eaton, UCLA 8970. Branch Canyon Sandstone/Caliente Formation, California, Miocene. 
GEOLOGICAL SURVEY

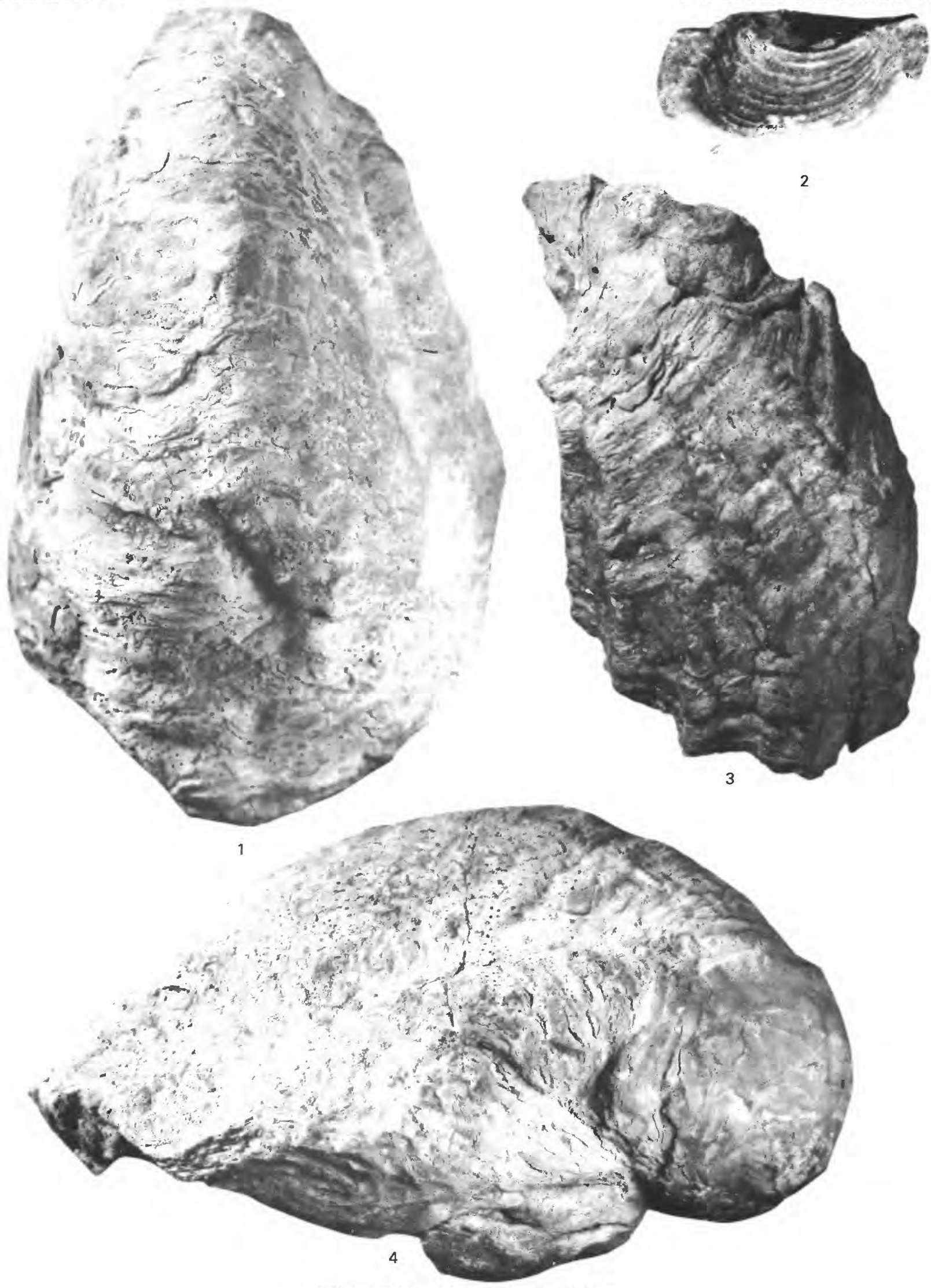

PYCNODONTE?, CRASSOSTREA? 


\section{PLATE 22}

Figures 1. Crassostrea? englekyi (Hertlein) (p. 38).

Holotype CAS 4116 ( $\times$ 0.7). Vaqueros Formation, California, Oligocene and Miocene.

2. Crassostrea? ashleyi (Hertlein) (p. 38).

Holotype of Ostrea hertleini Adegoke UCMP 36654. Temblor Formation, California, Oligocene and Miocene.

3-5. Striostrea? subtitan (Loel and Corey) (p. 34).

Holotype UCMP 31750. Vaqueros Formation, California, Oligocene and Miocene.

3. Right valve $(\times 0.7)$

4, 5. Left valve $(\times 0.8)$. 

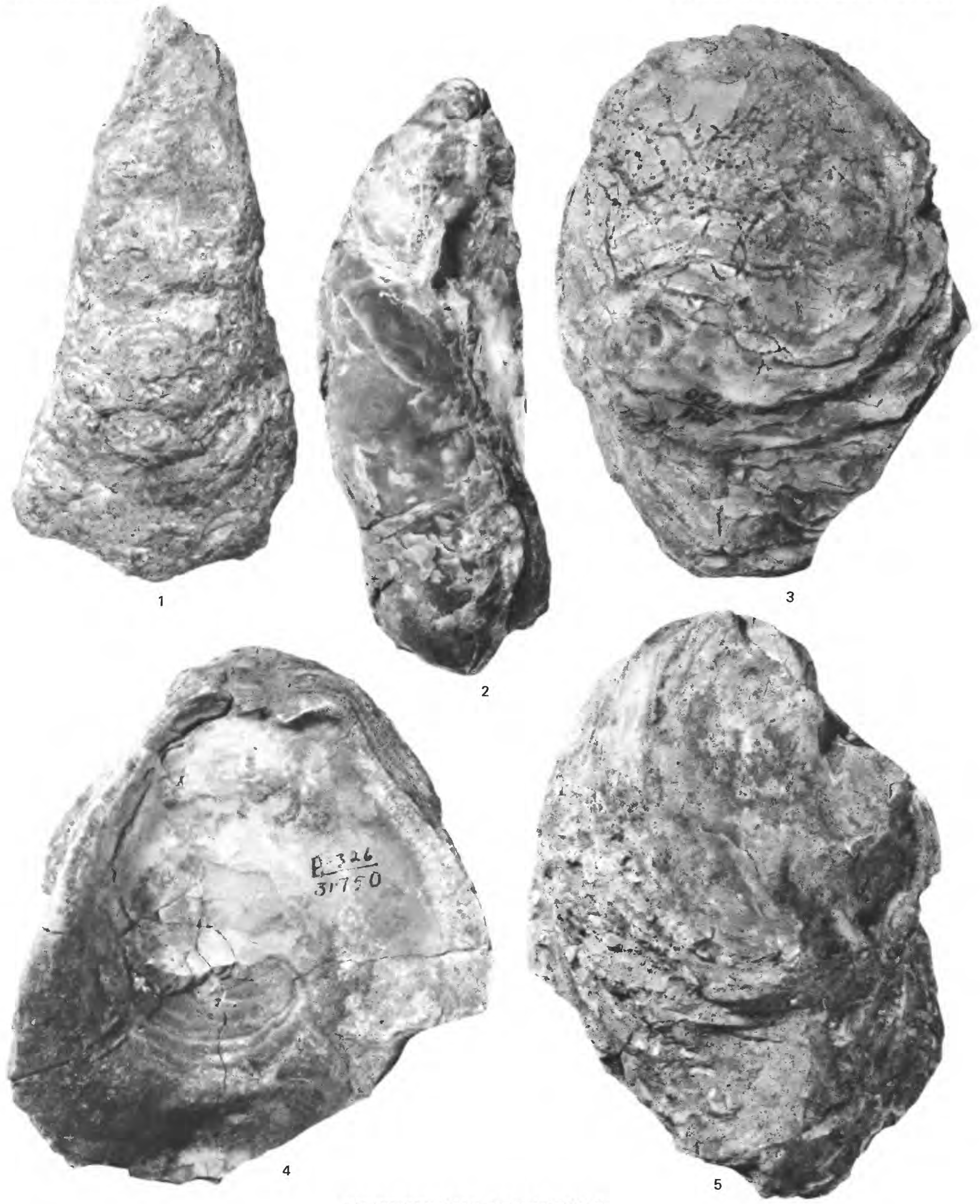

CRASSOSTREA?, STRIOSTREA? 


\section{PLATE 23}

Figures 1-7. Crassostrea titan (Conrad) (p. 35).

1. Hypotype of Arnold (1907a, pl. 45, fig. 2) USNM 164987. Topanga Formation, California, Miocene.

2, 6. Hypotype of Clark (1915, pl. 44, fig. 1) UCMP 15565. San Pablo Formation, California, Miocene.

3, 7. Holotype of Ostrea panzana Conrad USNM 13338. Santa Margarita(?) Formation, California, Miocene.

4, 5. Holotype of Ostrea subjecta Conrad USNM 13338. Santa Margarita(?) Formation, California, Miocene. 

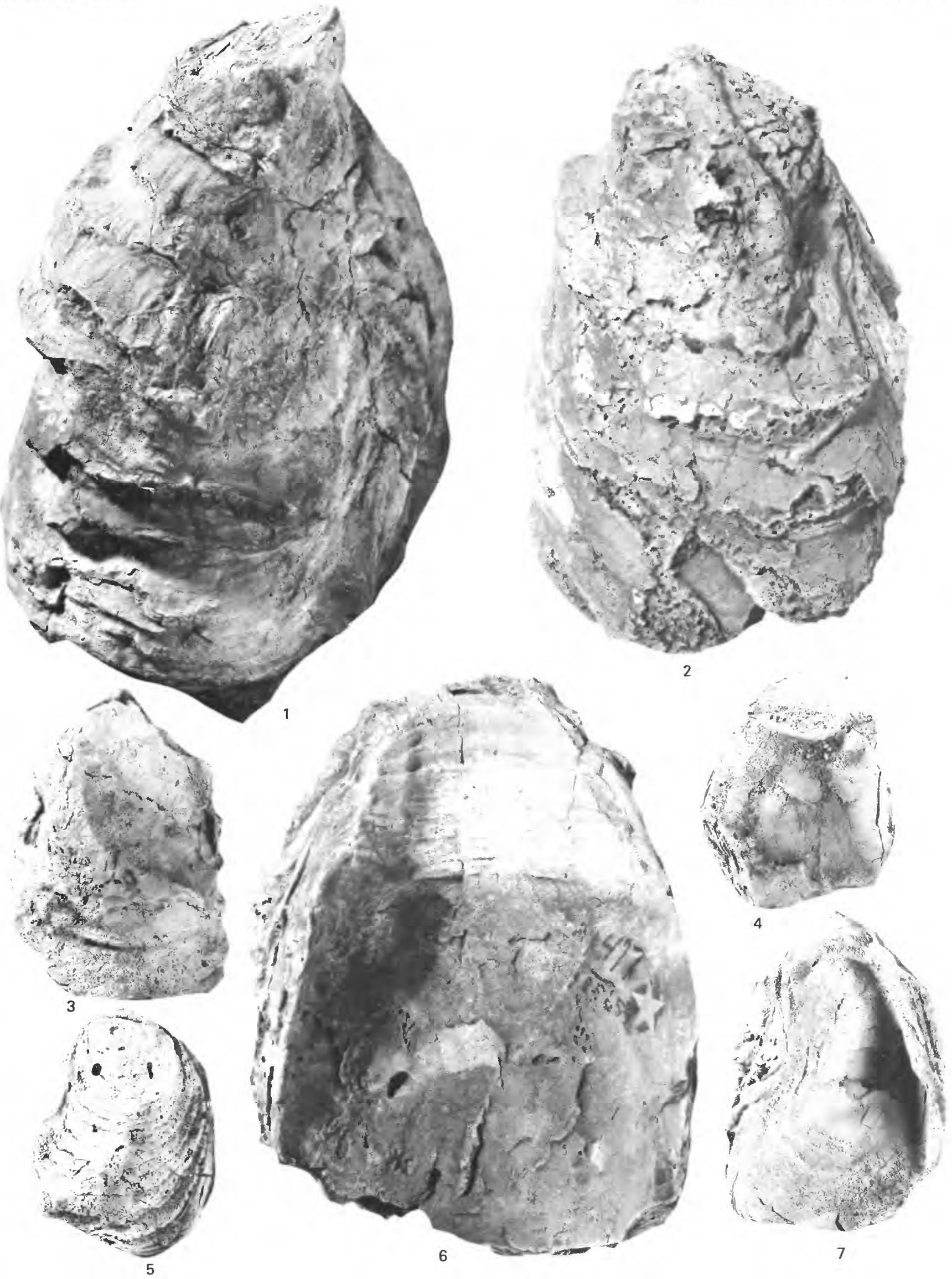

CRASSOSTREA 


\section{PLATE 24}

Figures 1, 3, 4, 6. Crassostrea titan (Conrad) (p. 35).

1, 6. Paratype of Ostrea titan andersoni Adegoke UCMP $36662(\times 0.5)$. Santa Margarita Formation, California, Miocene.

3, 4. Holotype of Ostrea titan andersoni Adegoke UCMP $36661(\times 0.5)$. Santa Margarita Formation, California, Miocene.

2. Crassostrea columbiensis (Hanley) (p. 37).

Hypotype of Ostrea chilensis Phillipi of Durham (1950, pl. 4, fig. 1) UCMP 15505. Unnamed Pliocene strata, Isla Carmen, Baja California Sur. 5. Crassostrea? ashleyi (Hertlein) (p. 38).

Holotype of Ostrea altatemblorensis Grant and Eaton UCLA 8970.

Branch Canyon Sandstone/Caliente Formation, California, Miocene. 


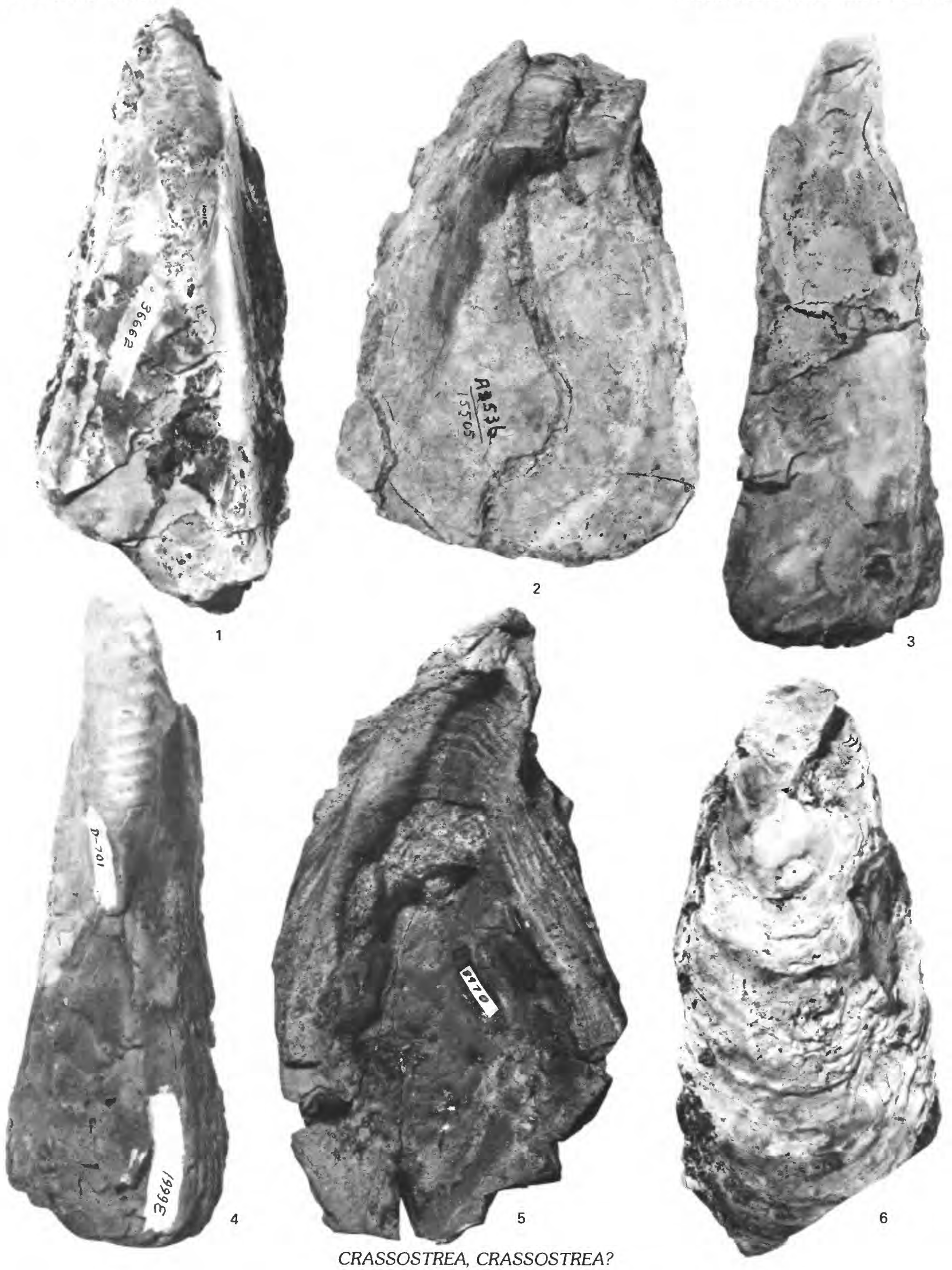




\section{PLATE 25}

Figures 1. Striostrea? bourgeoisii bourgeoisii (Rémond) (p. 34).

Hypotype of Clark (1915, pl. 43) UCMP 11566 ( $\times$ 0.5). San Pablo

Formation, California, Miocene.

2. Crassostrea? vaquerosensis (Loel and Corey) (p. 38).

Paratype CAS 6789 ( $\times 0.8$ ). Vaqueros Formation, California, Oligocene and Miocene.

3-5. Crassostrea? eucorrugata (Hertlein) (p. 39).

3. Holotype of Ostrea cierboensis Grant and Eaton, UCLA, $8980(\times$ 0.8). Cierbo Formation, California, Miocene.

4, 5. Holotype UCMP $11309(\times 0.4)$. Santa Margarita Formation, California, Miocene. 

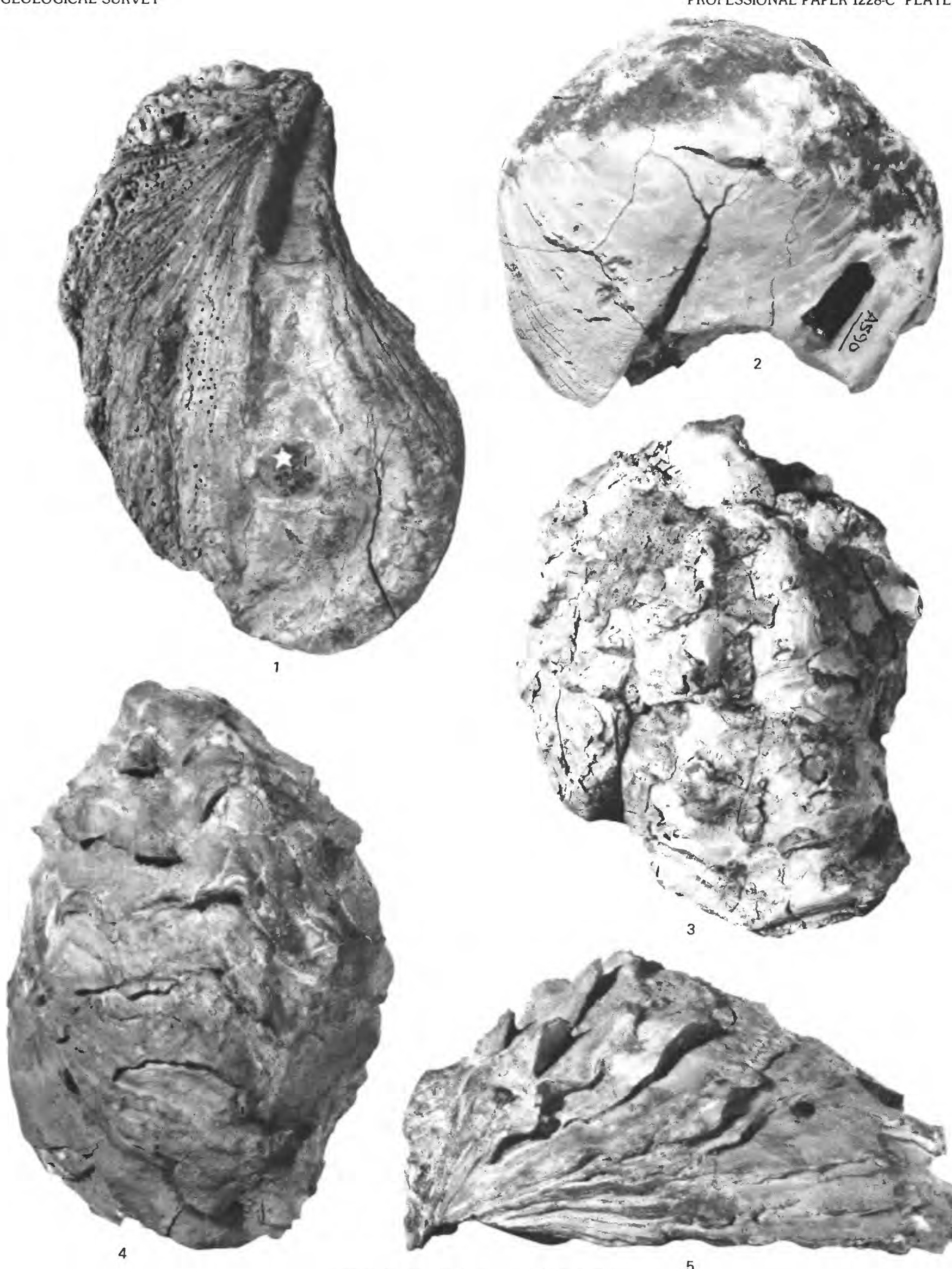

STRIOSTREA?, CRASSOSTREA?

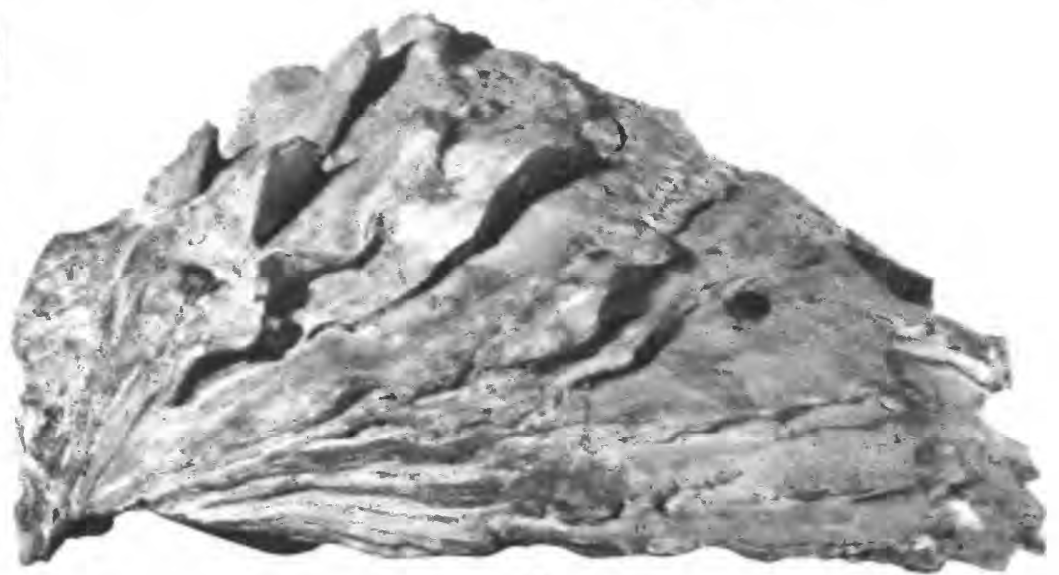




\section{PLATE 26}

Figures 1. Crassostrea? eucorrugata (Hertlein) (p. 39).

Holotype of Ostrea cierboensis Grant and Eaton UCLA 8980. Cierbo Formation, California, Miocene.

2. Crassostrea columbiensis (Hanley) (p. 37).

Holotype of Ostrea corteziensis Hertlein CAS 4288 ( $\times$ 0.8). Bahía Kino, Golfo de California, Sonora Mexico, Holocene.

3. Striostrea? freudenbergi (Hertlein and Jordan) (p. 34).

Holotype CAS/SU 5138. Isidro(?) Formation, Baja California Sur, Miocene.

4. Striostrea? bourgeoisii perrini (Hall and Ambrose) (p. 35).

Holotype CAS/SU $502(\times 0.7)$. Briones Formation, California, Miocene.

5. Striostrea? bourgeoisii bourgeoisii (Rémond) (p. 34).

Hypotype of Clark (1915, pl. 43) UCMP 11566 ( $\times$ 0.5). San Pablo

Formation, California, Miocene. 


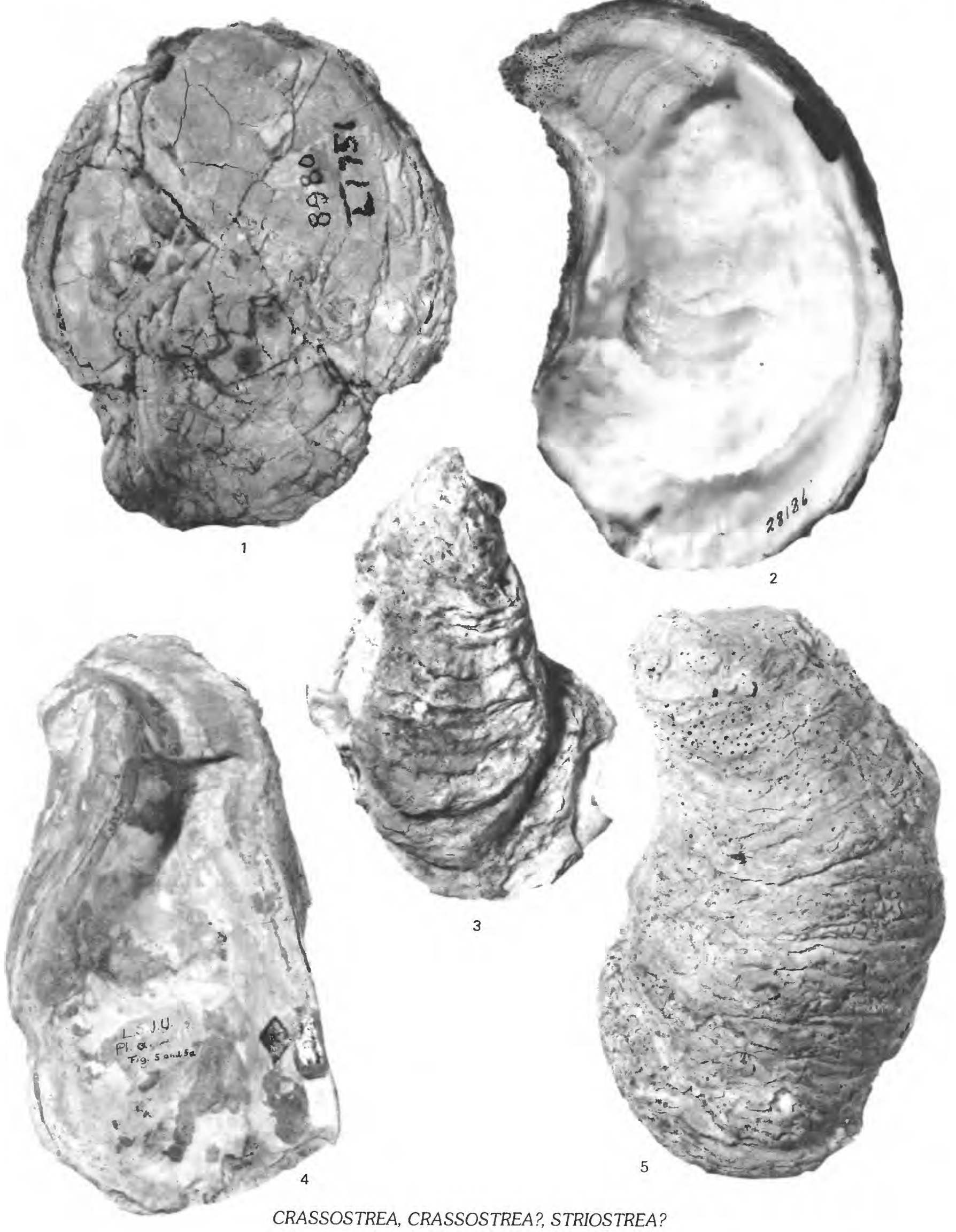




\section{PLATE 27}

Figures 1. Crassostrea? eucorrugata (Hertlein) (p. 39).

Holotype UCMP 11309 ( $\times$ 0.4). Santa Margarita Formation, California, Miocene.

2. Crassostrea? californica osunai (Hertlein) (p. 40).

Holotype CAS $12823(\times 0.5$ ). Salada Formation, Baja California Sur, Pliocene.

3. Striostrea? freudenbergi (Hertlein and Jordan) (p. 34).

Holotype CAS/SU 5138. Isidro(?) Formation, Baja California Sur, Miocene.

4. Crassostrea titan (Conrad) (p. 35).

Holotype of Ostrea titan prior Grant and Eaton UCLA 8991. Branch Canyon Sandstone, California, Miocene.

5. Striostrea? bourgeoisii perrini (Hall and Ambrose) (p. 35).

Holotype CAS/SU 502. Briones Formation, California, Miocene. 

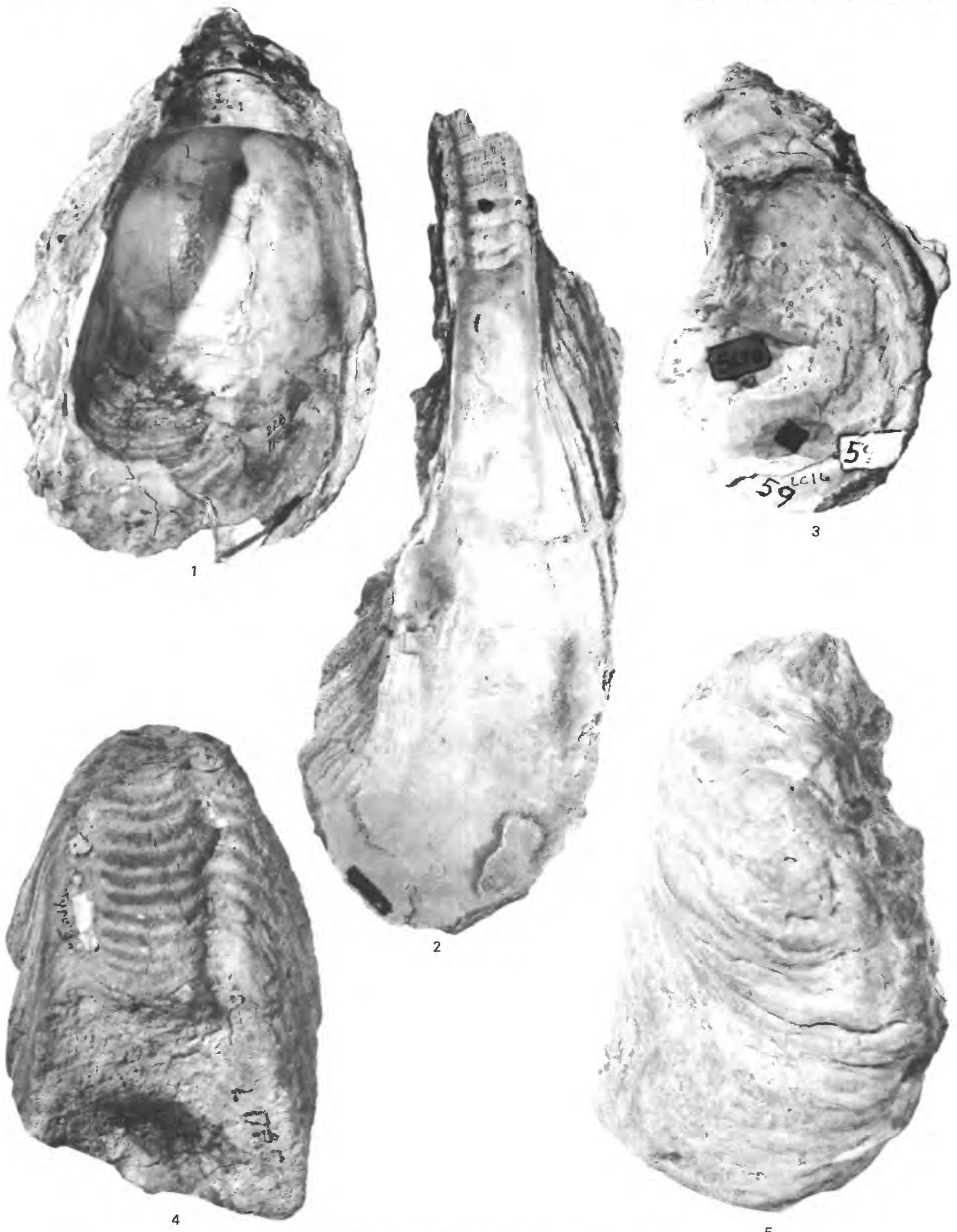

CRASSOSTREA, CRASSOSTREA?, STRIOSTREA?

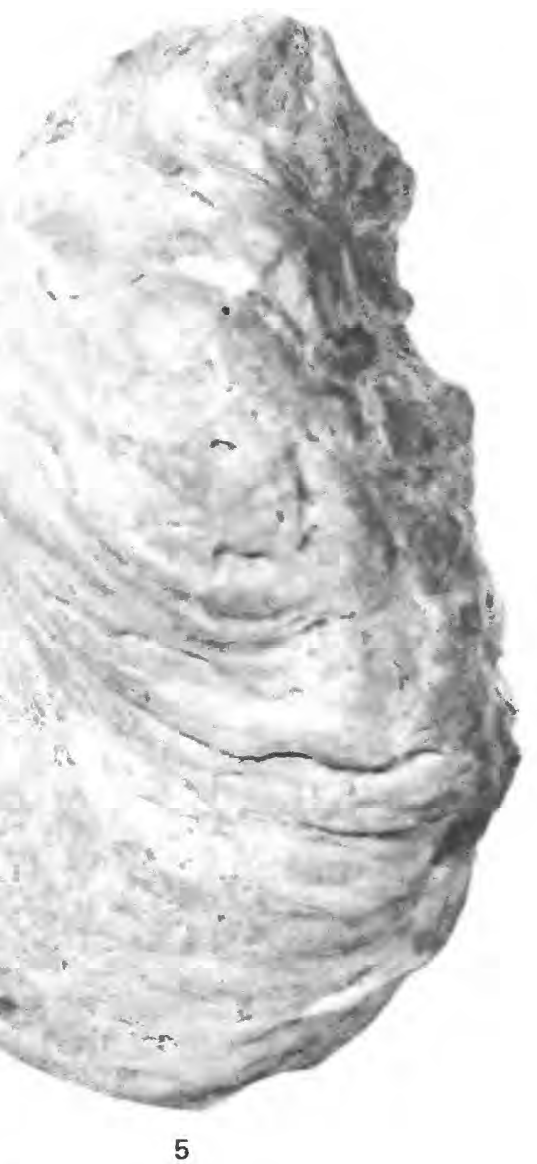




\section{PLATE 28}

Figures 1, 2, 4. Crassostrea columbiensis (Hanley) (p. 37).

Holotype of Ostrea corteziensis Hertlein CAS 4288 ( $\times 0.8)$. Golfo de California, Sonora Mexico, Holocene.

3, 5. Crassostrea titan (Conrad) (p. 35).

Holotype of Ostrea ligminuta Grant and Eaton, UCLA 8985 ( $\times 0.8$ ).

Branch Canyon Sandstone, California, Miocene. 

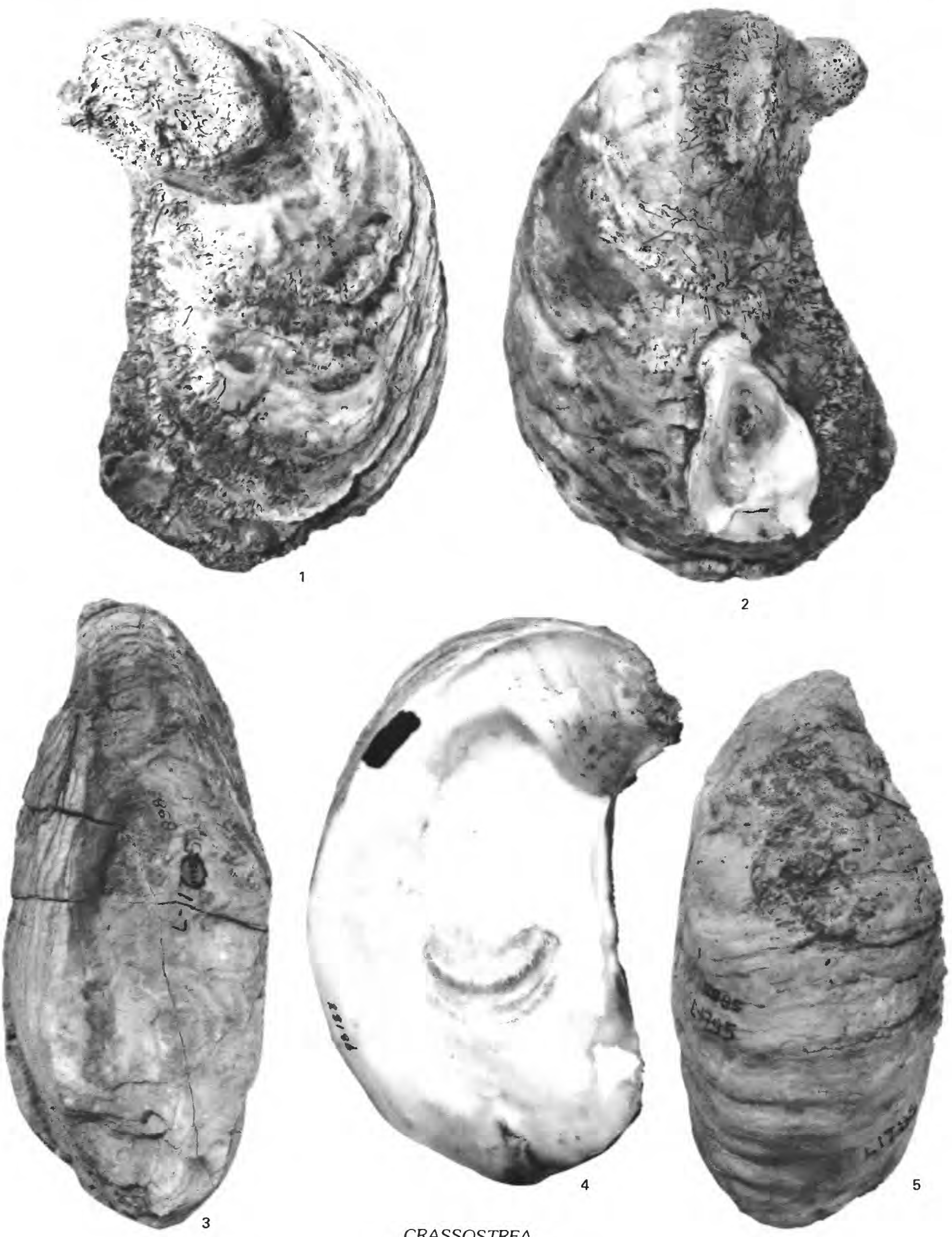


\section{PLATE 29}

Figures 1, 6. Crassostrea titan (Conrad) (p. 35).

1. Holotype of Ostrea titan prior Grant and Eaton, UCLA 8991. Branch Canyon Sandstone, California, Miocene.

6. Holotype of Ostrea ligminuta Grant and Eaton, UCLA $8985(\times 0.8)$. Branch Canyon Sandstone, California, Miocene.

2. "Ostrea" weaveri Dickerson (p. 29).

Holotype UCMP 32624. Martinez Formation, California, Paleocene.

3-5. Acutostrea idriaensis idriaensis (Gabb) (p. 31).

3,5. Holotype of Ostrea haleyi Hertlein CAS 5526. Cañada Formation, Santa Cruz Island, California, Eocene.

4. Photograph copied from Gabb (1869, pl. 34, fig. 103a).

7, 8. Striostrea? tayloriana (Gabb) (p. 33).

Holotype UCMP 12005. Gaviota Formation, California, Eocene and Oligocene. 

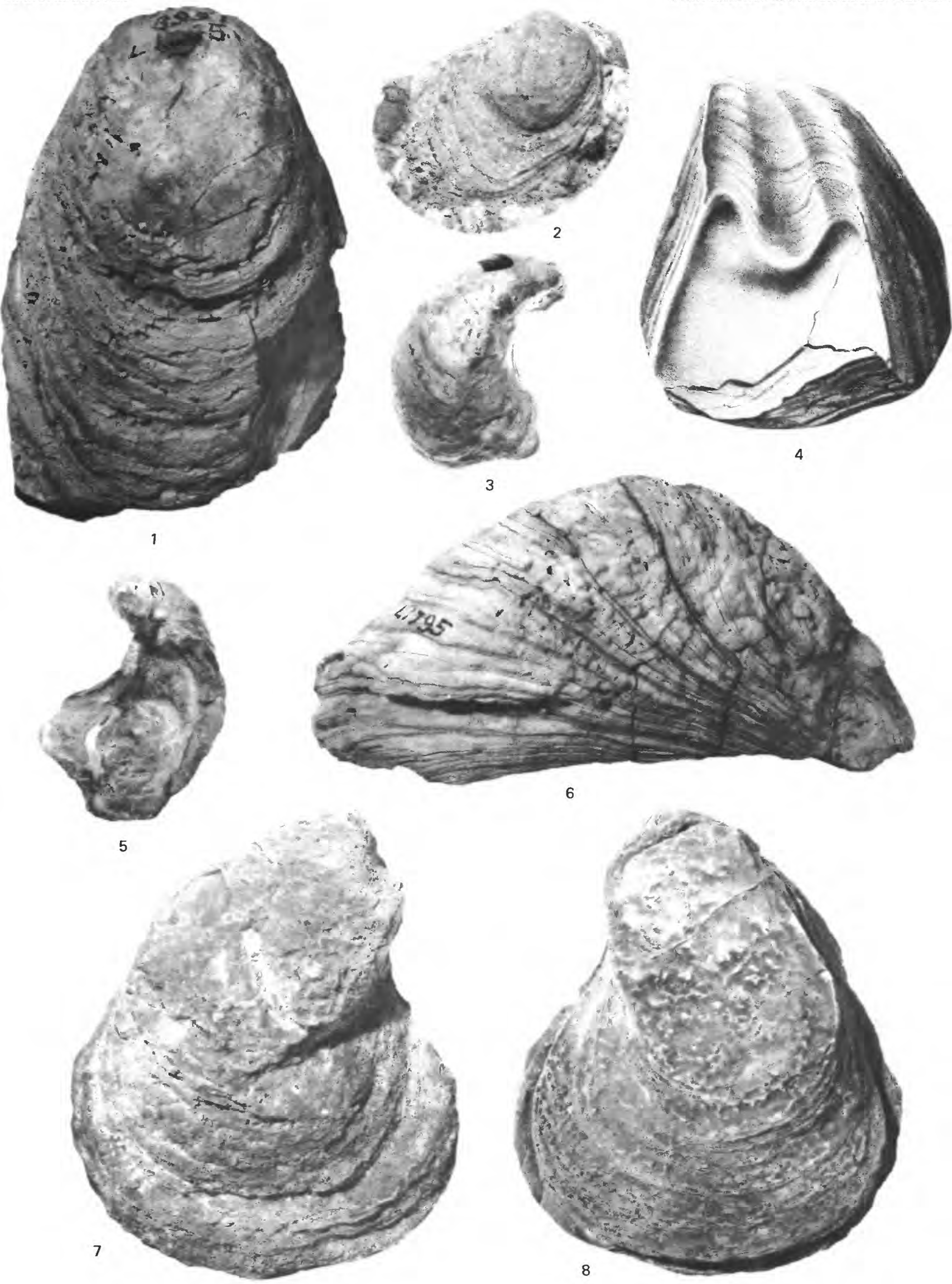

CRASSOSTREA, "OSTREA", ACUTOSTREA, STRIOSTREA? 


\section{PLATE 30}

Figures 1-4, 6, 8. Ostreola conchaphila (Carpenter) (p. 28).

1, 3. CAS $057760(\times 1.5)$. Olympia, Washington, Holocene.

2, 4. CAS 057761 ( $\times 1.5$ ). Olympia, Washington, Holocene.

6, 8. Hypotype of Howard (1935, pl. 7, fig. 5) CAS $7044(\times 2.0)$. San Joaquin Formation or upper part of Etchegoin Formation, California, Pliocene.

5. Acutostrea idriaensis fettkei (Weaver) (p. 30).

Holotype of Ostrea buwaldana Dickerson UCMP 11719. Martinez

Formation, California, Paleocene.

7, 9. Ostrea (Ostrea) atwoodii Gabb (p. 28).

Hypotype of Durham and Addicott (1965, pl. 3, figs. 3, 7) USNM 649094.

Pancho Rico Formation, California, Miocene. 

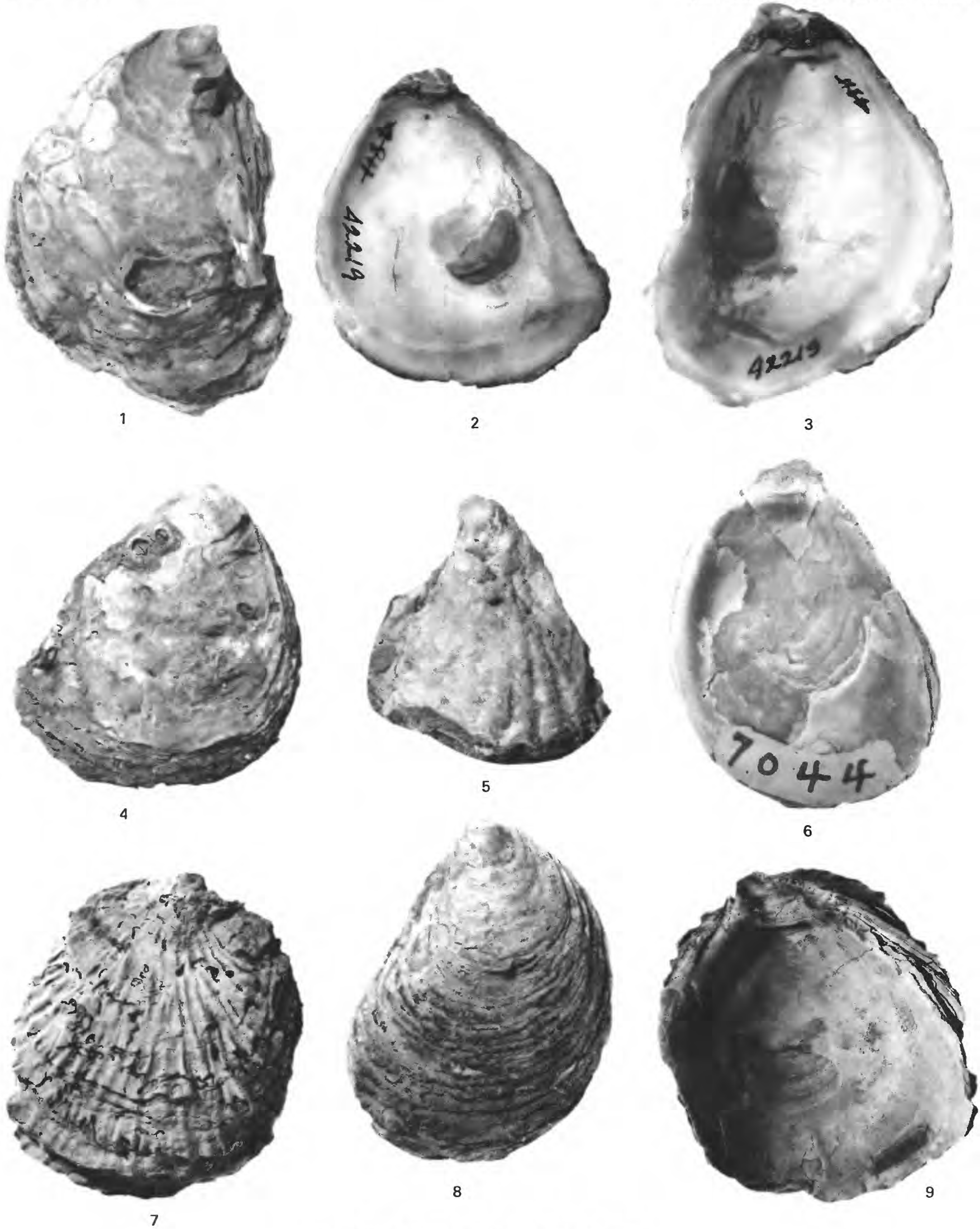

OSTREOLA, ACUTOSTREA, OSTREA 


\section{PLATE 31}

Figures 1-6, 8. Dendostrea? angermanni (Hertlein and Jordan) (p. 25).

1-4, 6. Hypotype UCMP 37535 ( $\times 1.5$ ). Imperial Formation, California, Miocene or Pliocene.

5, 8. Holotype CAS/SU 5137 ( $\times$ 1.5). Isidro(?) Formation, Miocene.

7. Ostreola? venturana (Loel and Corey) (p. 29).

Paratype UCMP 10035 ( $\times$ 1.5). Vaqueros Formation, California, Oligocene and Miocene. 

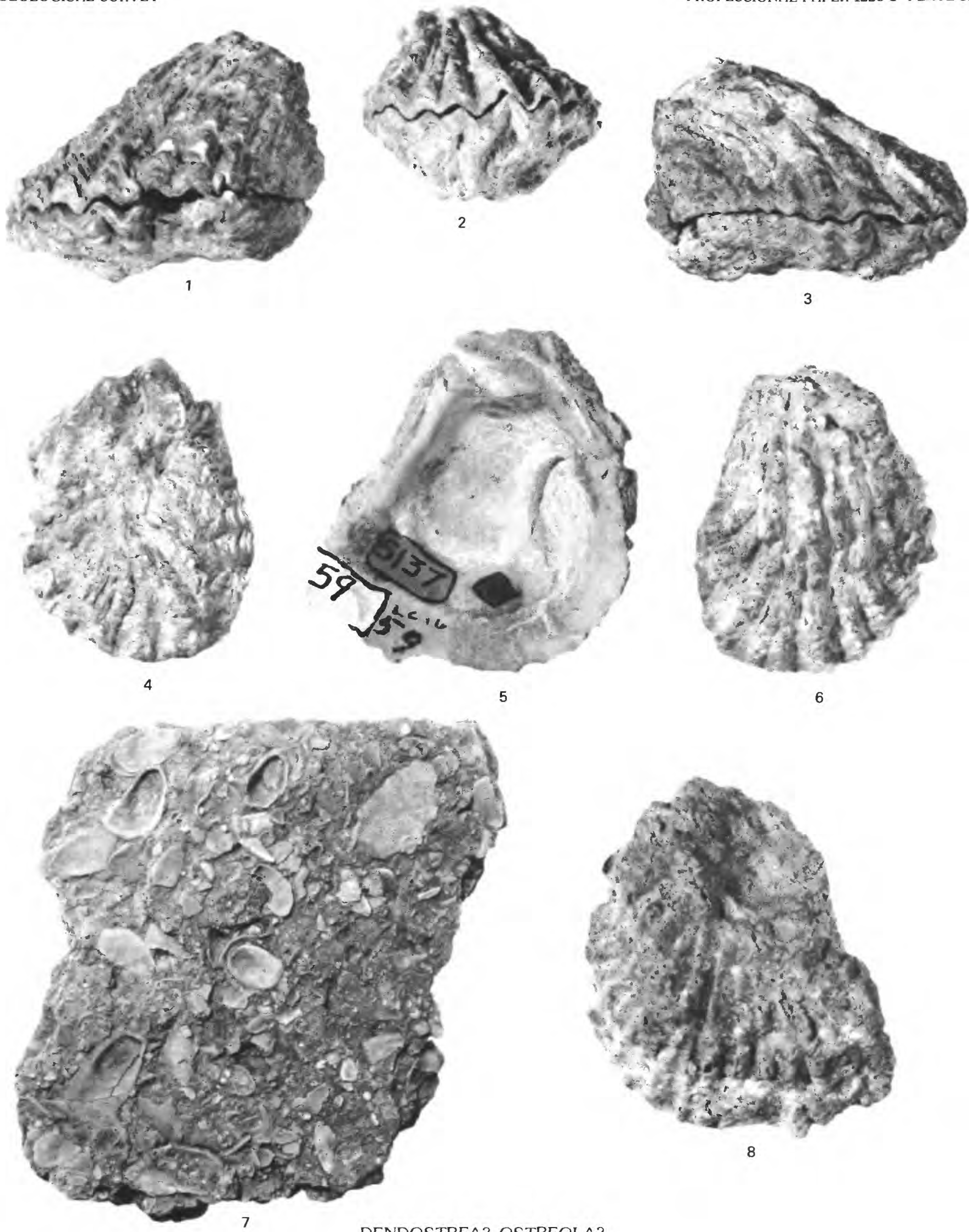

6

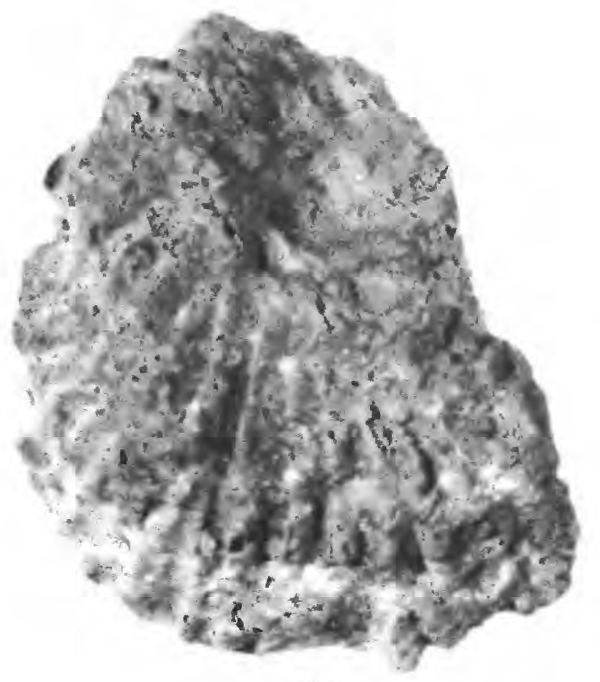

8

DENDOSTREA?, OSTREOLA? 


\section{PLATE 32}

Figures 1, 8, 9. Dendostrea? angelica (Rochebrune) (p. 26).

1, 8. Hypotype CAS 057786. Golfo de California, Holocene.

9. Hypotype of Durham (1950, pl. 5, fig. 7) UCMP 15955. Marquer Formation, Baja California Sur, Pliocene.

2, 5. Ostreola? megodon (Hanley) (p. 29).

2. Hypotype of Jordan and Hertlein (1926b, pl. 28, fig. 1) CAS 2093. Almejas Formation, Baja California Norte.

5. Lectotype of Ostrea cerrosensis Gabb ANSP 4494. Almejas(?) Formation, Baja California Norte, Pliocene.

3, 7. Neopycnodonte? cf. N. cochlear (Poli) (p. 23)

Hypotype of Ostrea cumingiana Dunker of Durham (1950, pl. 5, fig. 4)

UCMP 15425. Marquer Formation, Baja California Sur, Pliocene.

4,6. Acutostrea idriaensis fettkei (Weaver) (p. 30).

Holotype of Ostrea crandalli M. A. Hanna UCMP 31072 ( $\times$ 1.5). Delmar Formation, California, Eocene. 

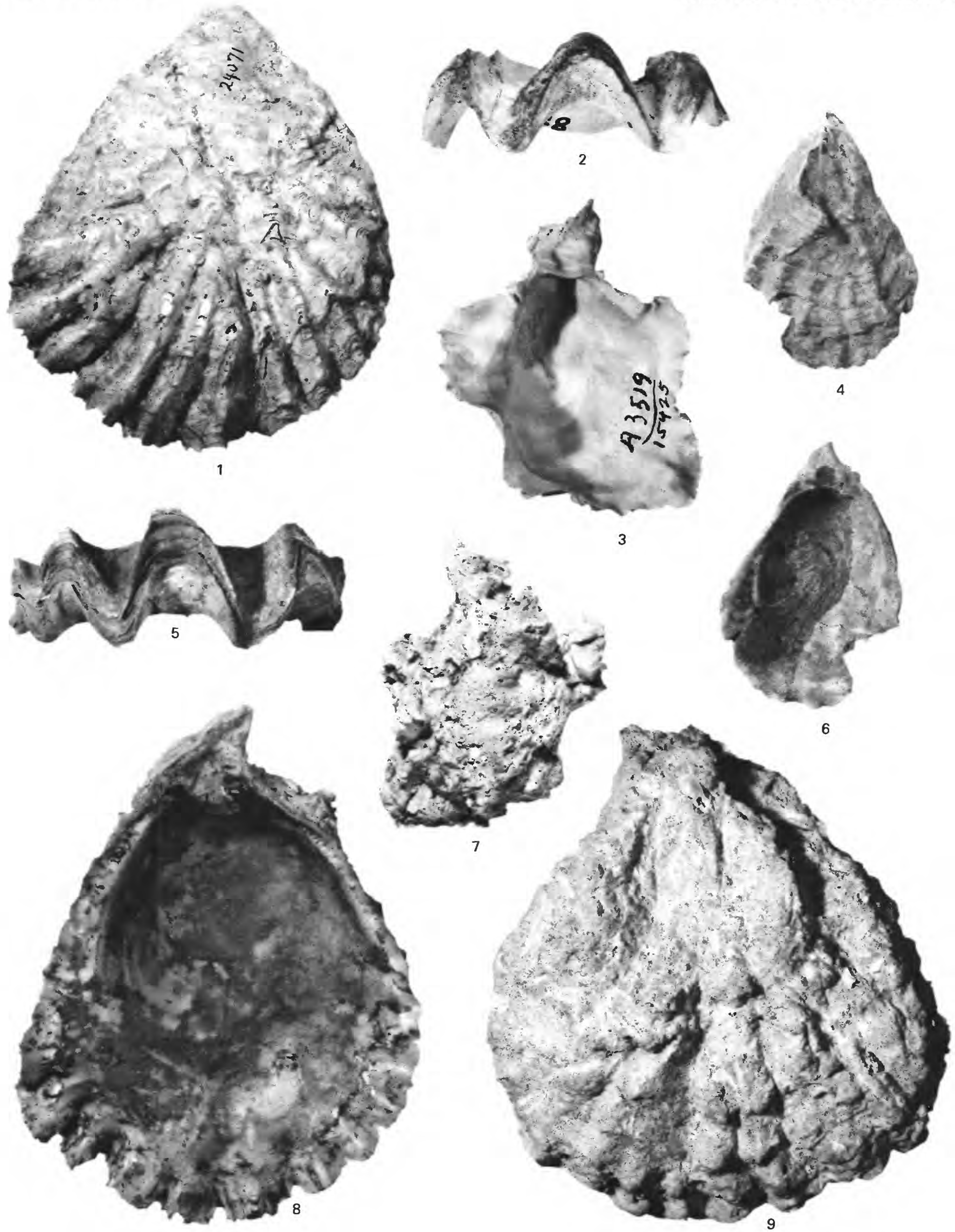

DENDOSTREA?, OSTREOLA?, NEOPYCNODONTE?, ACUTOSTREA 


\section{PLATE 33}

Figures 1-3, 8. Acutostrea idriaensis fettkei (Weaver) (p. 30).

1, 3. Holotype CAS 479 ( $\times 3.0$ ). Cowlitz Formation, Washington, Eocene.

2, 8. Paratype CAS 479a ( $\times 3.0$ ). Cowlitz Formation, Washington, Eocene.

4, 6, 7, 9. Acutostrea? miguelensis (Hertlein) (p. 32).

4, 6. Holotype CAS 4121 ( $\times 3.0$ ). Vaqueros Formation, California, Oligocene and Miocene.

7, 9. Paratype CAS 4122 ( $\times$ 3.0). Vaqueros Formation, California, Oligocene and Miocene.

5. Ostreola? venturana (Loel and Corey) (p. 29).

Holotype UCMP 31751 ( $\times 3.0$ ). Vaqueros Formation, California, Oligocene and Miocene. 
GEOLOGICAL SURVEY
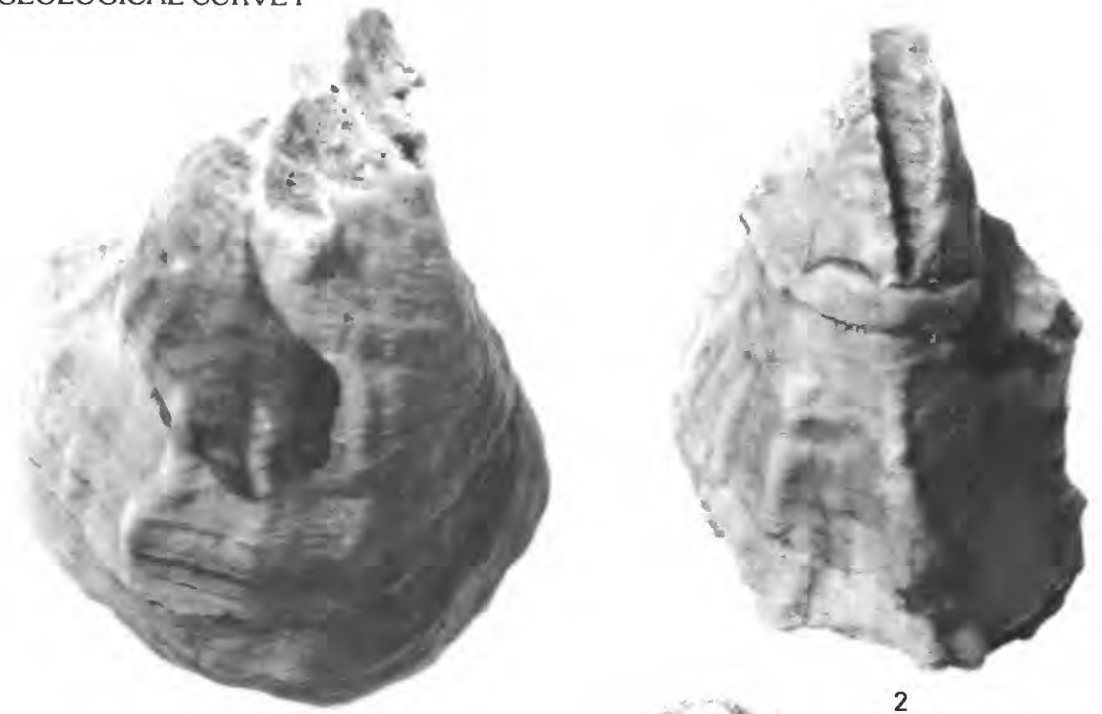

PROFESSIONAL PAPER 1228-C PLATE 33
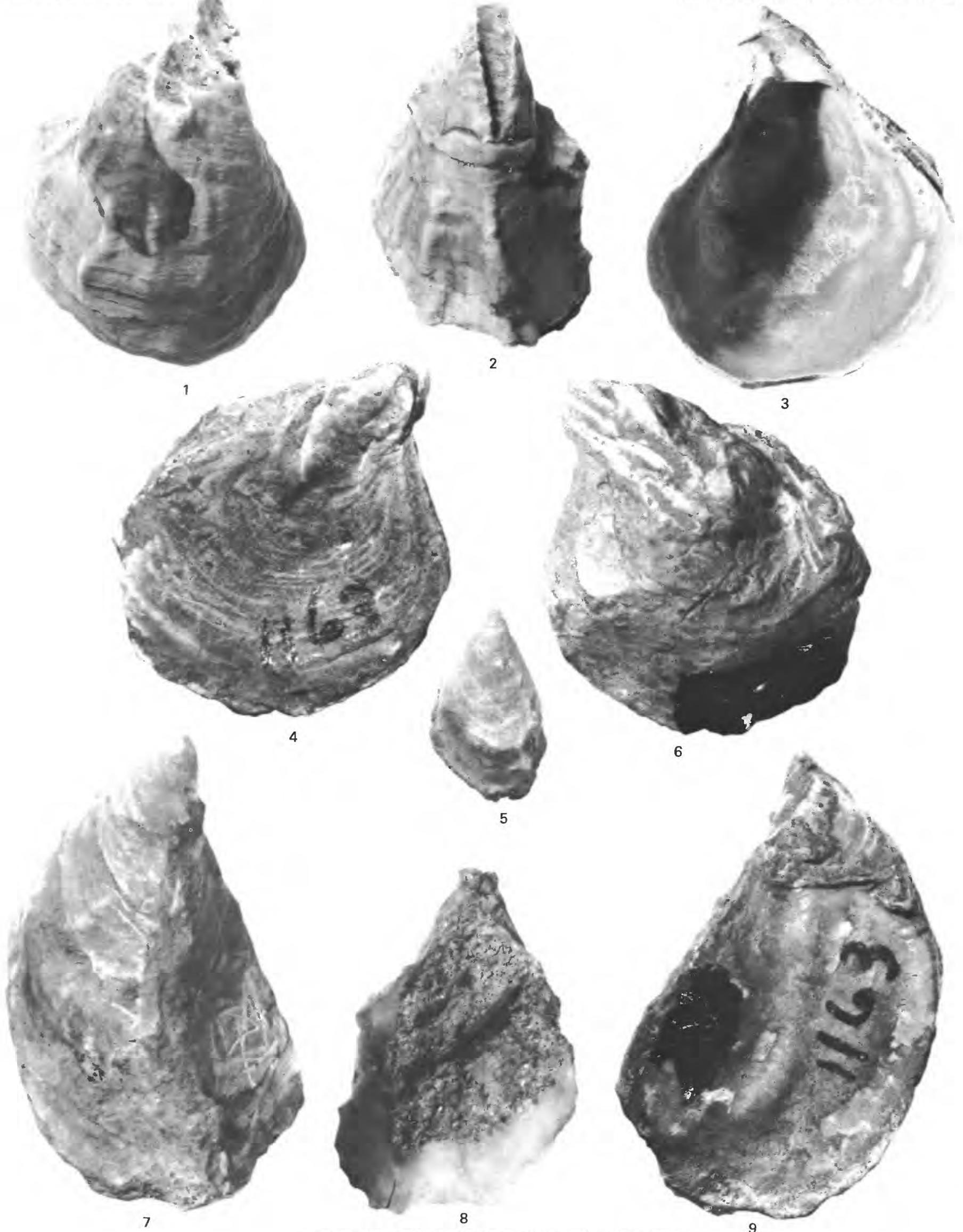

5

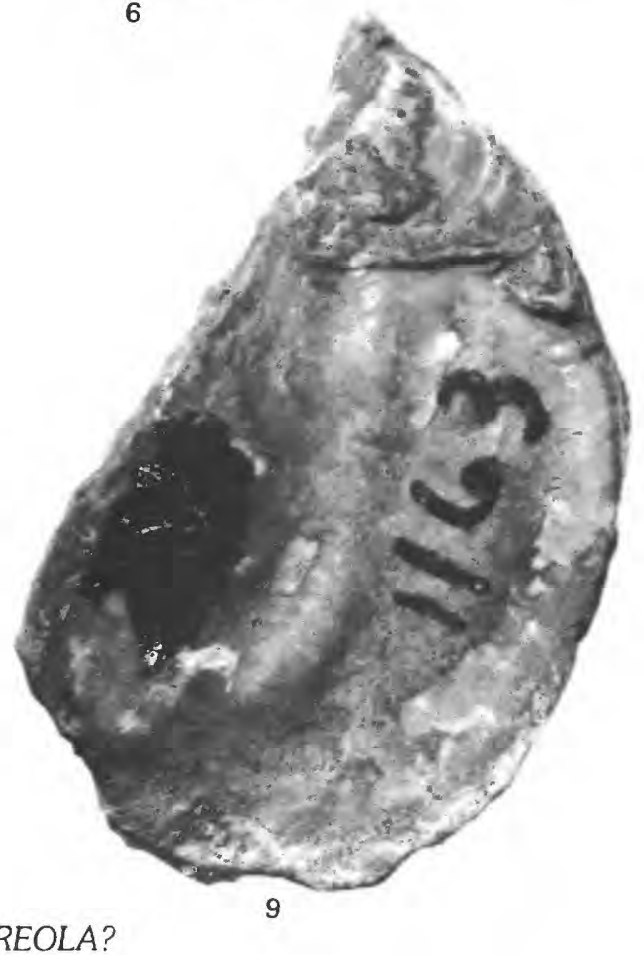

ACUTOSTREA, ACUTOSTREA?, OSTREOLA? 


\section{PLATE 34}

Figures 1, 3, 6, 8. Ostreola? megodon (Hanley) (p. 29).

1, 3. Hypotype of Jordan and Hertlein (1926b, pl. 28, fig. 1) CAS 2093.

Almejas(?) Formation, Baja California Norte, Pliocene.

6, 8. Holotype of Ostrea cerrosensis Gabb ANSP 4494. Almejas(?)

Formation, Baja California Norte, Pliocene.

2, 7, 9, 10. Dendostrea? angelica (Rochebrune) (p. 26).

2. Hypotype of Ostrea cumingiana Dunker of Durham (1950, pl. 5, fig. 6) UCMP 15424.

7, 9. Hypotype CAS 057762. Golfo de California, Holocene.

10. Hypotype of Ostrea vespertina Conrad of Durham (1950, pl. 5, fig. 7) UCMP 15955. Marquer Formation, Baja California Sur, Pliocene. 4, 5. Acutostrea simiensis (Zinsmeister) (p. 30).

4. Holotype UCR 6899/101. Simi Conglomerate, California, Paleocene.

5. Paratype UCR 6899/102. Simi Conglomerate, California, Paleocene. 
GEOLOGICAL SURVEY
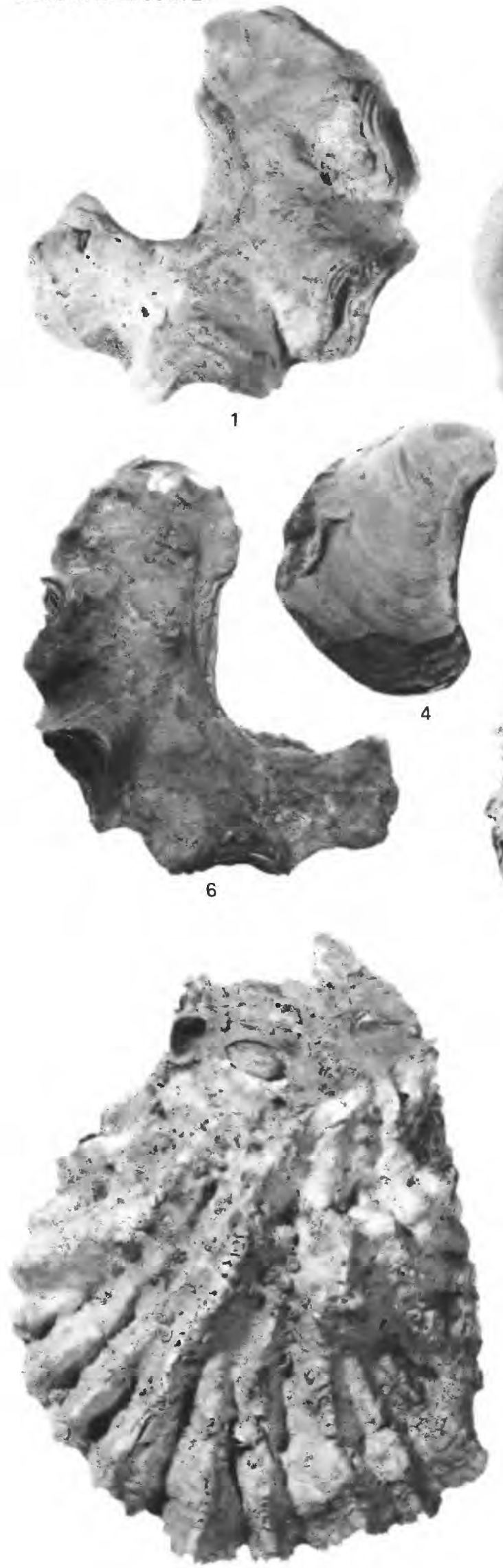

PROFESSIONAL PAPER 1228-C PLATE 34

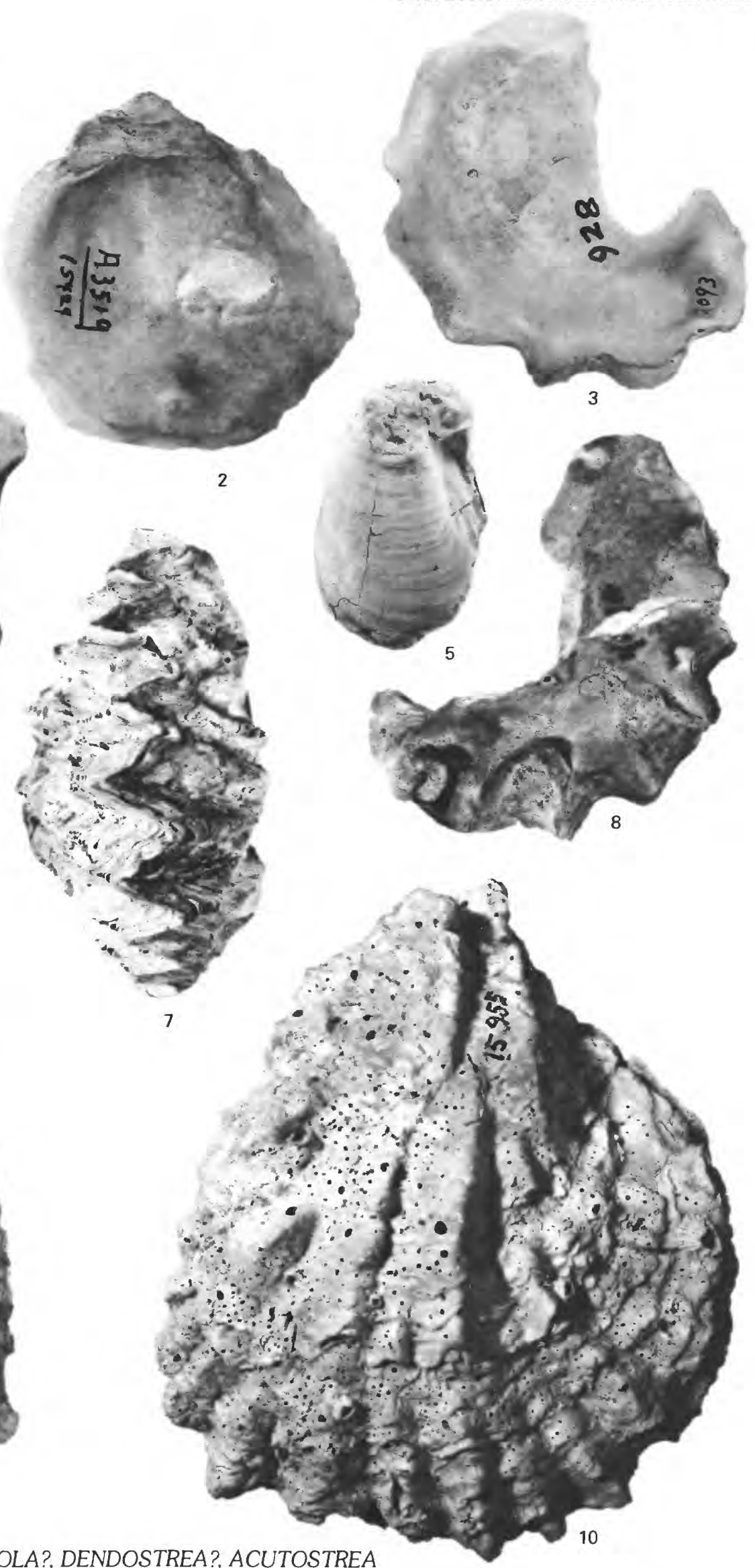

